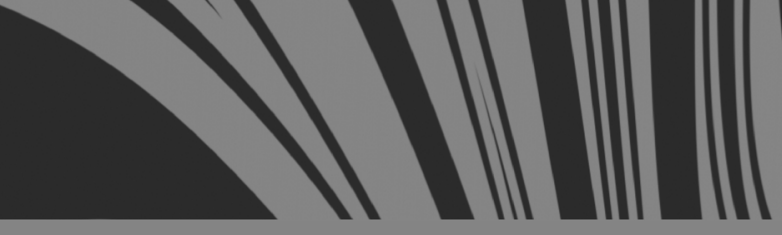

VEČDIMENZIONALNOST

SOCIALNOPEDAGQSKIH DISKURZQY 




\section{Večdimenzionalnost socialnopedagoških diskurzov}

Uredili Mateja Marovič in Andreja Sinjur 
Znanstvena monografija

Večdimenzionalnost socialnopedagoških diskurzov

Uredili - Mateja Marovič in Andreja Sinjur

Recenzenta - Torsten Fischer in Olivera Gajić

Lektoriranje in prevod povzetkov v angleški jezik • Monika Zanjkovič

Platnica " Aleš Gibičar

Oblikovanje, prelom in priprava na izdajo - Jonatan Vinkler

Izdala in založila

Založba Univerze na Primorskem (zanjo: prof. dr. Dragan Marušič, rektor)

Titov trg 4, SI-6ooo Koper

Glavni urednik " Jonatan Vinkler

Vodja založbe - Alen Ježovnik

Koper 2018

ISBN 978-961-7023-95-4 (pdf)

http://www.hippocampus.si/ISBN/978-961-7023-95-4.pdf

ISBN 978-961-7023-96-1 (html)

http://www.hippocampus.si/ISBN/978-961-7023-96-1/index.html

DOI: https://doi.org/10.26493/978-961-7023-95-4

(C) 2018 Založba Univerze na Primorskem

(1) $(\Theta \Theta$

Kataložni zapis o publikaciji (CIP) pripravili v Narodni in univerzitetni knjižnici v Ljubljani

COBISS.SI-ID $=294472960$

ISBN 978-961-7023-95-4 (pdf)

ISBN 978-961-7023-96-1 (html) 


\section{Vsebina}

\section{Mateja Marovič in Andreja Sinjur \\ 7 Uvod}

\section{Mitja Krajnčan}

11 Socialnopedagoške paradigme vzgajanja

Mateja Marovič

41 Razumevanje in opredeljevanje čustvenih in vedenjskih težav in/ali motenj v polju vzgojnih zavodov

Andreja Sinjur

65 Vključevanje priseljenskih učencev v slovenski zakonodaji in šolski praksi

Andrej Berdajs

89 Vodenje in (neprofitni) menedžment v socialni pedagogiki

Ana Bogdan Zupančič

109 Refleksija socialnopedagoškega diskurza osnovnošolskih praks

Mateja Marovič

129 Nameščanje in diskurz o (ne)ustreznosti vzgojne pomoči otrokom/mladostnikom s čustvenimi in vedenjskimi težavami in/ali motnjami v vzgojnih zavodih

Andreja Sinjur

149 Kaj vpliva na uspešno vključevanje priseljenskih učencev v slovenske šole

Andrej Berdajs

169 Delo s starostniki 
Mitja Krajnčan in Damjan Habe

189 Doživljajska pedagogika v Sloveniji skozi teorijo in prakso

207 Imensko kazalo

213 Stvarno kazalo 


\section{Uvod}

\section{Mateja Marovič in Andreja Sinjur}

Znanstvena monografija $\mathrm{z}$ naslovom Večdimenzionalnost socialnopedagoških diskurzov je plod dolgoletnih, dragocenih izkušenj praktikov in teoretikov, ki se pri svojem vsakodnevnem delu srečujejo z bolj ali manj depriviligiranimi ter ranljivimi skupinami posameznikov, z vzgojo, izobraževanjem in socialnopedagoškim delovanjem, hkrati pa se $\mathrm{v}$ polju omenjenih segmentov soočajo $\mathrm{z}$ vrsto različnih dilem in konceptualnih izzivov ter nenaklonjenimi posamezniki, ki zaradi spleta različnih dejavnikov in okoliščin - prisotnih $\mathrm{v}$ današnjem neoliberalističnem sistemu - ne zmorejo zadostiti lastnim pričakovanjem in pričakovanjem sodobne družbe.

Monografija, ki vsebuje devet prispevkov, zajema kontinuum, ki ne sega samo na polje socialnopedagoškega delovanja, temveč zajema tudi razumevanje okoljskega udejstvovanja posameznikov ter kontekstualni precep različnih družbenih skupin. Aplicira prostor socialne pedagogike kot podporne veje $\mathrm{v}$ vseh formalnih in neformalnih oblikah delovanja $\mathrm{v}$ različnih družbenih sredinah, vzgoje in izobraževanja kot dela šolskega sistema ter področje edukativnih in suportivnih pristopov delovanja, $s$ katerimi se avtorji pričujoče monografije pri svojem delu vsakodnevno srečujejo.

Identiteta Večdimenzionalnost socialnopedagoških diskurzov je tako $\mathrm{z}$ vso pravico artikulirana okrog pojma ranljivih družbenih skupin in posameznikov, ki se soočajo $\mathrm{z}$ različnimi ter mnoštvenimi težavami social- 
nega, emocionalnega, učnega, torej celostnega funkcioniranja »sodobnega« človeka.

Še beseda k naslovnici. Čeprav se v genealogijo pojma na tem mestu ne bomo podrobneje spuščali, pa simbolika znaka za neskončnost na naslovnici opredeljuje eno in edino stalnico v našem življenju - spremembo. Na podlagi tega simbol za neskončnost predstavlja védenje, da na celotnem področju socialnopedagoškega delovanja v monografiji omenjenih konceptov - v kontekstu »včeraj - danes - jutri« - nič ni omejeno, nič stalno in tudi nič nikoli dokončno dorečeno, temveč se vzporedno z družbenimi spremembami spreminjajo tudi doktrine predstavljene $\mathrm{v}$ pričujoči monografiji.

Monografijo pričenjamo s prispevkom Socialnopedagoške paradigme vzgajanja avtorja Mitje Krajnčana, ki analizira različne vzgojne diskurze in stile, osvetli metodiko dela $z$ vedenjsko težavnimi otroki in mladostniki, analizira pomembno vlogo (socialno)pedagoškega odnosa, kot osrednjega atributa uspešne vzgoje in izobraževanja, ter - predvsem z vidika dela $z$ vedenjsko težavnimi otroki in mladostniki - ponuja pomembno dodano vrednost celotni sferi vzgoje in izobraževanja, ki se s populacijo s posebnimi potrebami pri svojem delu vsakodnevno srečuje.

Prispevek Mateje Marovič, Razumevanje in opredeljevanje čustvenih in vedenjskih težav in/ali motenj $v$ polju vzgojnih zavodov, se osredotoča na opredelitve čustvenih in vedenjskih težav in/ali motenj, ki izhajajo iz različnih diskurzov razumevanja le-teh, ter ugotavlja, da tudi znotraj socialnopedagoške doktrine - ki je z opredeljevanjem omenjene populacije najbolj neposredno povezana - teorija in praksa velikokrat ne zavzemata istih stališč.

V prispevku Vključevanje priseljenskih učencev $v$ slovenski zakonodaji in šolski praksi avtorica Andreja Sinjur predstavi pomembnejše slovenske zakonodajne in druge dokumente, ki se nanašajo na pravico do vključevanja priseljenskih učencev v osnovno šolo. Avtorica predstavi tudi nekatere podporne oblike pomoči priseljenskim učencem $v$ zakonodaji in predvsem v šolski praksi, s katerimi bi priseljenskim učencem omogočili in bistveno olajšali spremljanje pouka ter socialno vključevanje v šolsko in lokalno okolje.

Prispevek Andreja Berdajsa, Vodenje in (neprofitni) menedžment $v$ socialni pedagogiki, se osredotoča na vodenje v neprofitnih organizacijah na socialnopedagoškem področju, upravljanje s človeškimi viri ter na ustvarjanje kulture neprofitne organizacije. Avtor ugotavlja, da je ravno upravljanje s človeškimi viri najpomembnejši segment, za katerega je značilno, da 
vodja zna izbrati prave osebe za konkretna delovna mesta, skrbi za njihovo motiviranost in možnosti profesionalnega razvoja.

V prispevku Refleksija socialnopedagoškega diskurza osnovnošolskih praks avtorica Ana Bogdan Zupančič analizira priložnosti socialnopedagoškega diskurza, se sprašuje o razlogih za pomanjkanje pravno formalne veljave socialne pedagogike $\mathrm{v}$ osnovnošolskem prostoru in razmišlja o socialnopedagoških potencialih pri zagotavljanju inkluzivnega okolja. Avtorica zastavlja tudi vprašanje, kako zagotoviti pogoje dela, ki bodo omogočali pedagoški etos zaposlenih.

$\mathrm{V}$ prispevku Nameščanje in diskurz o (ne)ustreznosti vzgojne pomoči otrokom/mladostnikom s čustvenimi in vedenjskimi težavami in/ali motnjami v vzgojnih zavodih avtorica Mateja Marovič na podlagi dolgoletnih izkušenj iz prakse, analize teoretičnih ter empiričnih izsledkov ugotavlja, da trenutno obstoječ sistem nameščanja (kot tudi obstoječe oblike zavodskih institucij) ni ustrezen, saj pogosto ne zadosti čedalje bolj kompleksni problematiki populacije, ki se v vzgojne zavode namešča.

$\mathrm{Na}$ vključevanje priseljenskih učencev $\mathrm{v}$ slovenski vzgojno-izobraževalni sistem ne vplivajo le različne politike vključevanja, temveč tudi nekateri drugi dejavniki. Avtorica Andreja Sinjur v prispevku Kaj vpliva na uspešno vključevanje priseljenskih učencev $v$ slovenske šole predstavi nekatere pomembne dejavnike, ki vplivajo na vključevanje priseljenskih učencev, na njihove izobraževalne/akademske dosežke ter njihov razvoj in uspeh skozi prizmo socialne pedagogike.

V prispevku Delo s starostniki avtor Andrej Berdajs ugotavlja, da zmanjševanje deleža aktivnega prebivalstva in povečevanje deleža vzdrževanega, višanje starosti za upokojitev, povečevanje delnega zaposlovanja starejših v organizacijo družbe postavlja nova razmerja, kjer bo potrebno preseči zakoreninjene stereotipe. Avtor poudarja pomembno vlogo socialnih pedagogov, ki obvladajo socialnopedagoške vsebine in tako prispevajo h kakovostnemu preživljanju starosti. Avtor ugotavlja tudi, da sta socialna pedagogika in pomoč ljudem v obdobju starosti kompatibilna, saj se socialnopedagoško delo lahko realizira tako $\mathrm{v}$ obstoječih institucijah kot tudi $\mathrm{v}$ obliki lastne podjetniške iniciative.

Monografijo zaključujemo s prispevkom Mitje Krajnčana in Damjana Habeta, Doživljajska pedagogika v Sloveniji skozi teorijo in prakso, v katerem avtorja skozi prizmo teoretičnih in praktičnih diskurzov bralcu predstavita temeljne elemente doživljajske pedagogike, njeno aplikativno vrednost na področju socialnopedagoškega vzgojno-izobraževalnega delovanja 
ter orišeta dodano vrednost tovrstnega pristopa v sistemu pomoči različnim socialno depriviligiranim skupinam mladih.

Še beseda k navajanju bibliografskih enot. V monografiji avtorji na določenih mestih posredno citirajo; vsi sekundarni viri so $\mathrm{v}$ polni obliki navedeni v primarno citiranih virih. 


\title{
Socialnopedagoške paradigme vzgajanja
}

\author{
Mitja Krajnčan \\ Univerza na Primorskem, Pedagoška fakulteta
}

Poučevanje, ki zapusti vtis, ni poučevanje iz glave v glavo, ampak iz srca $v$ srce. (Howard G. Hendricks)

\section{Uvod}

Podati razumevanje vedenja otroka je naloga socialne pedagogike, je želja učiteljev, staršev, odraslih. Kje tičijo čeri, kako lahko botrujemo poglabljanju težav, tako vedenjskih, čustvenih kot socialnih. Zakaj je vzgoja tako zahtevna, ob več ali manj jasni želji, da želimo otroku dobro. Žal pa pri nekaterih otrocih starši zaradi različnih razlogov, pogosto povezanih s socialno ekonomskim robom, revščino in mankom lastnih socialnih kompetenc, povezanih seveda še z mnogimi psihosocialnimi ter drugimi razlogi, tvorijo spiralo težav, ki prehajajo iz lažjih, ki jih tudi prepoznamo, do globljih in

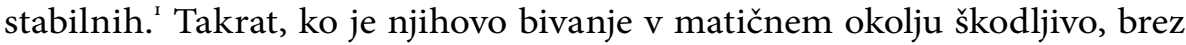
možnosti, da bi lahko prognozirali izboljšanje, ${ }^{2}$ je potrebno otroka napotiti v izvendružinsko vzgojo ${ }^{3}$ (Krajnčan, 2006).

1 Vsekakor bi na tem mestu logično pričakovali, da bodo lažje težave ob intenziteti in trajanju prešle v motnjo, kot smo navajeni v besednjaku, katerega še vedno, kljub stigmi in v praksi (posebej žal bolj tuji) dokazljivo tovrsten medicinsko usmerjen diskurz ne prispeva h kvalitetnejši in ustreznejši obravnavi. Tako je izraz pejorativen in neprimeren.

2 Tudi konvencije o otrokovih pravicah govorijo, da je potrebno narediti vse, preden se otrok izvzame iz družine.

3 Izvendružinske oblike pomoči, ki jih ponujamo v Sloveniji, so: rejništvo, vzgojni zavodi, stanovanjske skupine, mladinski domovi, mladinska stanovanja. Načrtovane 
Nadalje bomo ponudili diskurz vzgojnih stilov, ki skozi različne tipe prav tako išče optimalno vzgojno učinkovito držo vzgojiteljev do vzgajancev. Pogledali bomo različna poimenovanja, jih primerjali in poskusili opredeliti ustrezne postavke, ki bodo usmerjale h kvalitetni vzgoji. Pri tem implicitno iščemo odgovor o optimalnem profesionalcu - vzgojitelju. Potrebno je osvojiti metodiko dela s populacijo, ki ni težavna zato, ker bi to želela biti. Le na tem lahko sloni potreba po znanju, kako motivirati otro$\mathrm{ka} /$ mladostnika, kako zbuditi v njem premik, detektirati potrebe, interese, seveda glede na njegovo trenutno razvojno sposobnost in ponderjem nakopičenih težav. To je nujna kompetenca profesionalnih delavcev, saj le tako lahko razpozna, kdaj in kako otrok izraža svoje potrebe, kje ima delujoča področja, močne točke, ter kako se izogibati situacijam, s katerimi prične $\mathrm{z}$ neustreznim vedenjem. Vsekakor nič v socialnopedagoškem delu ni mogoče narediti s katero koli ciljno skupino brez ustreznega odnosa (Krajnčan, 2016).

Vsako spremembo vedenja, vsako neobičajno vedenje je potrebno vedno obravnavati kot simptom. Ta ali ti simptomi nas pogosto pripeljejo do otrokovih potreb, ki so prav tako pogosto povezane s starši in/ali celotno socialno mrežo otroka.

Vsi bi želeli imeti vzgojni priročnik, takšnega, ki bi zaobjel vse različnosti in ponudil seveda jasne rešitve za določeno težavo. Težave so tako mnogotere, tako heterogene in prepletene, povezane s specifiko vsakega posameznika, da bi s tovrstnimi tipskimi pristopi naredili več gorja kot koristi. Prav tako smo si različni akterji vzgoje, in tam, kjer smo eni uspešni, so lahko drugi neuspešni in obratno. Zato je potrebno ponovno poudariti, da je potrebno optiko usmeriti v razumevanje otrokovega vedenja, za kar pa je potrebno znanje. Prav tako je potrebno vedeti, da nas v tem grobem poznokapitalističnem svetu obdaja mnoštvo populistov, ki to delajo, da bi se lahko preživljali ali ker imajo potrebe po medijskem uveljavljanju. Kakorkoli, gre za zelo občutljive teme, kjer se posledice tovrstnega vedenja in prodajanja všečnih besed ne izmerijo in so lahko etično sporne.

Članek analizira predvsem vzgojo v vzgojnih ustanovah, se pravi profesionalno vzgojo. Ponuja dodano vrednost v razmišljanju tako v vrtcih, šolah, dijaških domovih, domovih, kjer živijo in delajo ljudje s posebnimi potrebami, posebej pa bi omenil vzgojne zavode, mladinske domove in stanovanjske skupine, ki so ali bodo v prihodnje združeni v strokovne centre.

so nove oblike v preoblikovanju vzgojnih zavodov v strokovne centre, kar bom opisal kasneje. 
Človek lahko postane človek samo skozi vzgojo.

\section{Vzgoja}

Kaj je torej vzgoja? Vzgoja je torej celostno delovanje, vse tisto, kar moramo posredovati otrokom in mladostnikom, kar bodo $\mathrm{v}$ življenju rabili. Hurrelmann in Bauer (2015, str. 13) definirata vzgojo kot socialno interakcijo med ljudmi, pri čemer odrasli poskuša $\mathrm{z}$ načrtno in ciljno usmerjenim delovanjem ter upoštevanjem otrokovih potreb in individualnih posebnosti doseči ali ojačati želeno vedenje. Vzgoja je sestavni del celostnega procesa socializacije. Odrasli poskuša zavestno delovati v procesu razvoja osebnosti otroka, s ciljem graditi samostojnega, zadovoljnega in odgovornega človeka.

Freire v svoji knjigi Pedagogika avtonomije (2017) pravi, da se od ustreznega (pravega) pedagoga zahteva: metodološka strogost, raziskovanje, spoštovanje znanja in izkušenj učenca, kritični duh, etika in estetika, izkustveno prikazovanje življenja, prevzemanje tveganja, spremljanje novitete in zavrnitev vseh oblik diskriminacije, zavest o nepopolnosti, pogojenosti, avtonomiji posameznika, ki ga vzgaja, zdrav razum, skromnost, toleranca, borba za pravice, občutek za realnost, radost in upanje, prepričanje, da je sprememba mogoča, radovednost, varnost, profesionalna kompetentnost in velikodušnost, angažma, svoboda in avtoriteta, sprejemanje odločitev, sposobnost poslušanja, sprejemanje ideološke različnosti, odprtost za dia$\log$ in dobronamernost do vzgajancev.

V. Spajić Vrkaš (2001, str. 17) navaja nekaj ključnih zahtev, s pomočjo katerih kreiramo realno vzgojo:

- $\quad$ vztrajanje na holistični teoretski refleksiji, torej na celostnosti življenjske/vzgojne situacije;

- ozaveščanje medsebojne odvisnosti delov in celote po pravilih sinergije;

- afirmiranje individualne izkušnje, ki jo osmišljajo občutki in intuicija;

- neposredno povezovanje človekovega razvoja s kvaliteto interpersonalne verbalne in neverbalne komunikacije;

- razkritje zatiralnih družbenih mehanizmov, ki onemogočajo afirmacijo individualne izkušnje in z njim povezane multiple realnosti sodobnega človeka. 
Vzgoja, kot pravita Russell in Loughran (2007), je vpletena v mrežo družbenih, političnih, ekonomskih, ekoloških in moralnih kriz, ki je zapletena bolj kot kadarkoli v zgodovini človeškega bitja. ${ }^{4}$ Očarani s svojim egom ne občutimo, kako smo duhovno zaspani. V bistvu smo priča globalni krizi, ki ne pretresa samo družbe, temveč vse bolj tudi posamezni$\mathrm{ka}$, ki ga usmerja v ponovno preverjanje lastne zavesti in odgovornosti. In tukaj so mladi, mlajši in še mlajši v zelo zahtevni poziciji. Vzgoja je namenjena usmerjevanju $\mathrm{k}$ želeni smeri in ne $\mathrm{k}$ prepovedovanju neželenih smeri. Posameznika je potrebno ozaveščati, da je izjemen, da je unikaten. Personalizacija je sestavljena iz razvijanja tistega, kar je pri vsaki osebnos-

Odrasli<smiles>[Te][Te]</smiles>

Načrtna in ciljno

usmerjena

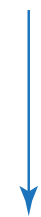

Otrok

Socialna interakcija

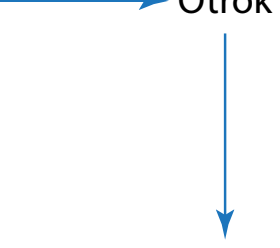

Z upoštevanje potreb in individualnih posebnosti

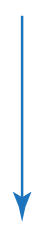

\section{Socializacijski proces}

ti posebnega, preko česa se lahko razvija lastno spoštovanje in samozavest.

Proces vzgoje po Hurrelmannu in Bauerju (2015):

Cilj: razvoj osebnost otroka: samostojnega, zadovoljnega in odgovornega človeka.

Hurrelmann in Bauer (2015) razlikujeta prav tako med intencionalno in funkcionalno vzgojo. Pod intencionalno vzgojo razumemo zavestna in načrtovana vzgojna delovanja in vzgojne ukrepe. Preko njih lahko posameznike opremljamo $\mathrm{z}$ vrednotami, ki bodo vplivale na razvoj osebnosti. Funkcionalna vzgoja $v$ nasprotju $\mathrm{z}$ intencionalno vzgojo označuje vse druge vzgojne učinke na posameznika iz okolja, brez pedagoškega vplivanja in ciljev, torej brez zavestnega vplivanja.

4 Kljub relativno starejši letnici te misli, menimo, da je danes še bolj aktualna in zapletena. 
Kako postaviti pravilne meje na pravilnih mestih? To je pravi izziv za vsako vzgojo! Vzgoja je zahtevna naloga, ni lahek posel. Vsak starš bi želel narediti najboljše za otroka, vendar se kaj kmalu lahko zalomi. Zakaj? Torej, vsi smo si na jasnem, da moramo otrokom postaviti meje. Vendar, kje točno potekajo?

Poskus kompletne definicije vzgoje, ki se izogne tej ali oni smeri, ki pomeni znanstveno nevtralnost in želeno objektivnost v svoji kompleksnosti, prepletenosti in bistvu, je vsled interesne asertivnosti nemogoč. Včasih se zdi presplošen, včasih preveč determinirajoč. Naša želja ni, da bi ustvarili novo teorijo, vsekakor pa želimo opozoriti na mnogoterost želja in interesov, ki pogosto izhajajo s področja vzgoje.

Drama vzgajanja je vedno tukaj, je vedno prisotna, saj je njen rezultat neizvesten, rizičen, posebno glede usklajevanja zahtev osebnega razvoja in družbenih zahtev, torej personalizacije in socializacije osebnosti. Pri tistih, kjer se ta proces odvija skladno, je lahko rezultat harmoničen in zadovoljen, srečen posameznik. Bolj kot vzgoja viša integriteto posameznika, bolj je oseba avtentična. V obratni smeri je lahko ta drama v simboliki vzgoje tudi tragedija. Uspeh po družbenih meril o tem, kaj je uspešnost, še ne pomeni, da se je oseba dejansko samoaktualizirala. Zato je pomembno, da se kot vzgojitelji zavedamo, kako pomembno je odkriti notranjo skladnost (Tausch in Tausch, 1998; Wexberg, 1998; Damm, 2014).

In še enkrat, menimo, da takšen način, usmerjen samo v kognicijo, ni po meri otroka, hkrati pa se je pokazal kot neučinkovit in nefunkcionalen. Učenci se usmerjajo ${ }^{5} \mathrm{k}$ memoriranju dejstev, principov, metod vzgoje skozi fizično, intelektualno, moralno, estetsko in delovno tehnično vzgojo, pri čemer izgubimo pogled na celovitost razvoja osebnosti. Sama delitev področja vzgoje ni usklajena s tistimi vzgojnimi nalogami, ki bodočega vzgojitelja, učitelja čakajo v konkretnem pedagoškem delovanju. ${ }^{6}$ Učni predmeti $\mathrm{v}$ šoli nimajo samo izobraževalne vloge, ampak tudi vzgojno. Izobraževanje in vzgoja se odvijata paralelno, torej tako v šoli kot izven nje.

Brezinka (2017) pravi, da je vzgoja skupno ime za vse uporabljene uspešne in neuspešne poskuse, ki želijo spremeniti vedenje, posebej otrok, $\mathrm{v}$ želeno smer. Tako se vzgoja nanaša na pedagoški vpliv na razvoj in veden-

5 Posebno depriviligiran položaj imajo v takšni šoli učenci s posebnimi potrebami.

6 To si upamo napisati, saj imamo od zgoraj, ali s strani EU, vsiljene normative, zahteve, kakšni morajo biti učni načrti, kolikšna razmerja morajo biti med teoretičnimi vsebinami in prakso. Ob obiskih tujih univerz po Evropi, posebej tistih držav, ki veljajo za "prvo ligo", je prav boleče videti, da imajo zelo drugačne visokošolske in univerzitetne študije, kar pomeni, da smo mi spet bolj papeški od papeža. 
je odraščajočih, pri čemer koncept vključuje tako proces kot rezultat tega vpliva.

Vzgoja pomeni iskanje smisla. Humanistični aspekt, ki stoji pred vzgojiteljem, pred socialnim pedagogom, ga postavlja pred veliko odgovornost, kako bo kompenziral pomanjkanje kritičnega odnosa do družbe. Kako bo na tržišču družbe vzgajal neperspektivne in odvržene? Kako bo izražal nezadovoljstvo in nestrinjanje? Kako bo socialno konstruiral in dekonstruiral vzgojo? Obenem pedagogika gradi svoje perspektive - humanistične usmeritve, pri čemer seveda zavrača instrumentalizacijsko logiko. Prvič, izraz upravljanje (menedžment) je tržni izraz, grožnja z njegovo uporabo v osebnih razmerjih (in v pedagoškem kontekstu) je, da na ta način omogoča depersonalizacijo osebnih odnosov s spodbujanjem vključevanja ekonomske logike v takšna razmerja (Kohn, 1999). Izraz sam ima konotacijo nadzora, pomeni spremembo, oz. uvaja razmerje podrejeni - nadrejeni. Giroux (2013), ki se opre na ugledna pedagoga Freira in Deweya, pravi, da ne smemo dovoliti ustvarjanja izobraževanja po vzoru poslovnega sveta. Pri tem ugotavlja, da se bodo v primeru, da se bo nadaljevala praksa šol, kot da upravljajo podjetja, preko trženja in uvajanja tržnih vrednot in kaznovalnih disciplinskih ukrepov, iz šol umaknile teze o demokratičnemu vodenju. »Potem bo šolstvo in vzgoja naslednja žrtev v seriji vedno manjšega števila institucij, ki so sposobne negovati kritično razmišljanje, pravičnost, javno razpravo in skupno sprejemanje odločitev« (Giroux, 2013, str. 23). Izobraževanje v svojem bistvu temelji na moralnem diskurzu in ne komercialni logiki. Samo v izobraževalnem okolju sodelovanja, samoupravljanja in demokratičnega vodenja se lahko naučijo, »kako naj delujejo kot posamezniki in družbeni subjekti in ne kot nezainteresirani opazovalci ..." (Giroux, 2013, str. 26). In kot vodilno misel, povezano s socialno pedagogiko, bi navedli, da je osnovno delovanje socialnopedagoškega dela vzgoja. ${ }^{7}$

\section{Vzgojni stili}

Vzgojni stili predstavljajo možnosti vedenja učitelja/vzgojitelja, dejavnosti, ki jih prakticira v svojem delovanju. Vzgojni stili so umetno konstruirani sistemi reda in niso realno določene značilnosti vzgojnega vedenja. Tema si je tako v teoriji kot praksi skozi čas izoblikovala preživeto fascinacijo. Vzgojne drže in stališča se v večji meri odražajo s socialnimi pričakovanji,

$7 \quad$ To tezo smo želeli poudariti, saj se je, vsaj v mojem času izobraževanja, na oddelku za socialno pedagogiko PEF UL in kasneje, ko sem bil zaposlen kot asistent in visokošolski učitelj, rado polemiziralo, kaj sploh je socialna pedagogika in kaj je vzgoja. 
idejnimi tokovi, predvsem pa v družbenih pogojih in možnostih, ki so delovale $\mathrm{z}$ individualnimi in družinskimi ter ostalimi socializacijskimi možnostmi in mejami. Strokovne intence v času, ki zaradi družinskih in družbenih sprememb išče nove usmeritve, pogosto tudi nove izraze ali celo stare $\mathrm{v}$ novih preoblekah, zahtevajo analitično primerjavo razpoložljivih diskurzov. Potrebna je sinteza primerljivih teorij vzgojnih stilov in oblikovanje funkcionalnega vzgojnega stila, ki ima osnovno intenco v svoji učinkovitosti in ozaveščanju pomena izraženega vzgojnega/učnega delovanja.

Najprej bomo predstavili temeljne vzgojne stile, ob njih pa vzgojne stile, ki so jim podobni, oziroma tiste klasifikacije, ki jih težko razvrstimo v katero od skupin. Prav tako bomo kot dodano vrednost članka predstavili sintezo vzgojnih stilov in dodali poskus funkcionalnega integralnega modela (Bauer in Einhardt, 2014; Damm, 2014; Fritsch in Ockhardt, 2010; Riedel, 2004; Tausch in Tausch, 1998; Maccoby in Martin, 1983).

\section{Avtoritaren vzgojni stil}

Se izkazuje s stalnim nadzorom in nizko stopnjo odzivnosti (sprejetosti). Vzgojitelji pogosto opominjajo in imajo nadzorno vlogo. Postavljena so stroga pravila in avtoriteta pod vprašajem. Nezaželenemu vedenju sledi trdo kaznovanje, lahko tudi fizično. Številne študije so pokazale, da avtoritarno vzgojeni otroci tudi sami kasneje izkazujejo agresivnost. Temelji na nagrajevanju in kaznovanju in zelo malo na prepričevanju, posreduje pa večinoma varnost (Buchmann, 2007; Fritsch in Ockhardt, 2010; Gutzwiller Helfenfinger, 2015; Satow, 2013).

Posebna oblika je avtokratičen vzgojni stil, kjer je nad vzgajanim izrazita avtoriteta. Lastne iniciative in mnenja vzgajanih se ne dopuščajo, ampak se zatirajo.

Značilnost avtoritarne vzgoje je tudi, da je velik del aktivnosti določen s strani vzgojiteljev ali staršev. Otrok je v svojem vedenju in razmišljanju nadzorovan in usmerjan po predstavah odraslih. Pri tem so pogosti ukazi, navodila in odredbe. Starši neznatno upoštevajo potrebe in želje otrok. Pogosto so otroci, ki so bili tako vzgajani, oštevani in grajani. Avtoritarni starši imajo do otrok visoke zahteve, dajejo pa malo emocionalne podpore. Učinki avtoritarnega vzgojnega stila na otroka se lahko kažejo v omejenosti kreativnosti, spontanosti, saj starši zahtevajo večji delež aktivnosti in se odzovejo na bore malo pobud s strani otrok. Otroci so v večji meri tisti, ki svoj klic na pomoč kažejo z agresivnostjo in tak način želijo pozornost. Pogosto prevzamejo besede staršev in izkazujejo egocentrično usmerjene 
besede (jaz, moje, meni, zame). Otroci takšne vzgoje so pogosto nesamostojni, nesamozavestni in $\mathrm{z}$ občutkom manjvrednosti (Bauer in Einhardt, 2014; Levin, 2012).

Avtoritaren vzgojni stil ima po Hurrelmannu (2007) naslednje značilnosti: aktivno poseganje v osebnostni razvoj otroka, sposobnost se soočati preko potreb otroka in uporaba telesne kazni. Učinki so lahko: agresivni in nasilni vzorci vedenja, upor, odpor, puntanje, neposlušnost, zlom pravil, napadi besa, izogibanje kontakta s starši, izstop iz šole, zloraba drog, neprilagojeno, klečeplazno vedenje, slabo razvita samostojnost in socialna odgovornost ter šibka storilnostna aktivnost.

Avtoritaren vzgojni stil Anderson (Gerr, 2014) za področje šolstva opredeljuje kot dominanten vzgojni stil. Predstavlja rigorozno skupinsko vodenje, vse določa vzgojitelj/učitelj. Kaznovanje in grajanje se pogosto uporabljata, vzgojitelj/učitelj želi predvsem izvajati po svojih strokovnih predstavah in prepričanjih. Dominanten stil sproži sovražno, odklonsko, lahko tudi apatično vedenje. Otroci se vedejo protislovno, se upirajo učitelju in ustrahujejo šibke sošolce. Takšen stil vodi do določene samodinamike. Dominantno vedenje učitelja izzove otrokovo agresijo proti njemu, kar pri učitelju vodi do še strožjih reakcij. Dominanten vzgojni stil učiteljev do učencev se izkazuje v: monopolu odločanja, nesamostojnosti, ukazovanju, upornosti proti željam učencev, opominjanju, grožnjah, konfliktnosti, diskriminaciji, prisili, strogem nadzoru, vodenju pouka ipd.

\section{Avtoritativen vzgojni stil}

Avtoritativen vzgojni stil se izkazuje skozi visoko stopnjo nadzora in visoko stopnjo sprejetosti do vzgajanega. Starši imajo visoka pričakovanja do otrokovega vedenja, postavljajo jasne standarde in pravila, ki se izvajajo dosledno. Generalno gledano obstaja odprta komunikacija, pri čemer se upoštevajo otrokova stališča, kakor tudi zagovarjanje svojih stališč. Otroci izkazujejo visoke socialne in intelektualne kompetence in posedujejo visoko stopnjo samokontrole (Bauer in Einhardt, 2014; Levin, 2012).

Baumrind (2008) pravi, da je ta vzgojni stil usmerjen $\mathrm{v}$ jasne zahteve in ob tem ponuja visoko stopnjo podpore. Starši morajo pri svojih zahtevah vztrajati in/ali želje otroka postaviti ob rob, četudi to izzove upor otroka. Če pri tem nastala konfrontacija vodi do brez prisilnega pogajanja ali do skupno predelane rešitve, to utrjuje samozavest otroka in razširja repertoar komunikacijskih zmogljivosti. Ta vzgojni stil po raziskavah prinaša razvoj sposobnosti otroka, pozitivno samopodobo in optimalne kompetence 
pri socialno odgovornem vedenju, strategijah vedenja in strategijah premagovanj težav.

V avtoritativni vzgoji ima vzgojitelj visoke, vendar realne zahteve, postavlja realne standarde in pravila, pri čemer otroke upošteva, vsekakor takrat, ko je to utemeljeno. Vzgojitelji otroka spodbujajo k avtonomiji in oblikovanju lastnih stališč, na katera so pozorni prav tako kot na svoja. Avtoritativna vzgoja je usmerjena k drži, kjer otrok vzgojitelja zanima in zastopa držo resnega pogovornega partnerja (Maccoby in Martin, 1983).

\section{Vzgojni stil zanemarjanja}

Permisivni starši pomanjkljivo vodijo, usmerjajo in kontrolirajo. Otrokom dajejo zelo malo zahtev, popuščajo njihovim impulzom, prepuščajo, da sami upravljajo svoje vedenje. Poskušajo, kolikor je mogoče, malo predpisovati in se tudi izogibajo kaznim (Bauer in Einhardt, 2014).

Permisiven vzgojni stil lahko opredelimo $\mathrm{z}$ naslednjimi značilnostmi: opustitev starševskega poseganja $\mathrm{v}$ razvoj otrokove osebnosti in nobenih jasnih pravil v odnosu med starši in otroki. Starši otrokom ne nudijo ustrezne starševske avtoritete (malo pozornosti in ljubezni) in so minimalno usmerjeni v potrebe otrok. Učinki so naslednji: jeza in zmeda skozi manjkajoče norme, izguba pravil kot primanjkljaj pozornosti in ljubezni, agresivno vedenje, da bi si pridobil pozornost in ljubezen, naravnanost nase namesto na socialne odgovornosti, oportunizem nasproti dosežkov ter razvoj samostojnosti, ki je nejasen in brez varnosti. Počutijo se osamljeni, prezrti in neupoštevani (Hurrelmann, 2007).

Pri zanemarjajoči vzgoji pravzaprav ne moremo govoriti o vzgoji, saj so starši praktično neudeleženi v razvoju otroka. Zanj nimajo interesa, so čustveno hladni, ne postavljajo zahtev in preživijo $\mathrm{z}$ njim zelo malo časa (Maccoby in Martin, 1983).

Laissez-faire kot vzgojni stil, v katerem je otroku prepuščeno praktično vse, kjer ni jasnih struktur. Starši oziroma vzgojitelji se vmešavajo v otrokovo življenje samo takrat, kadar je res nujno. Do otrok se vedejo prijazno, vendar nevtralno, pomagajo, ko to zahtevajo otroci. Otroci imajo v svojem razvoju veliko težav, tako na odnosni ravni, storilnostni, odgovornostni ipd. (Buchmann, 2007; Hurrelmann, 2007).

\section{Razvajajoč vzgojni stil}

Razvajanje ali »crkljanje« je odnosni vzorec med posameznikom in družbo, ki je vtisnjen v ranem otroštvu skozi držo vzgojitelja (njegov vzgojni 
stil), in ustvarjalnim odgovorom otroka (življenjskim stilom). Besedo je uvedel Alfred Adler, danes uporabljamo tudi pojem hiperprotektivna vzgoja ali »overprotection «.

Razvajen otrok predstavlja življenjski stil otroka, ki želi biti veliko bolj razvajen od otroka, ki je resnično razvajen.

Oporne točke za prikaz razvajajoče vzgoje po Wexbergu (1998) so naslednje: zasut $\mathrm{z}$ nežnostjo, zanesenost občudovanja ob vsakem dosežku, brezmejnost laskanja nad njegovo lepoto in inteligenco, otrok je v središču pozornosti v družini, vsako željo otroka prebrati že iz oči, otroku pustiti vse in se prepustiti, da nas tiranizira, otroku vzeti vsako možnost, da bi prevzel lastno pobudo.

Helikopter starši in podobni termini se pojavljajo ob opisu različnih vidikov vedenja staršev, ki so prisotni s stalno skrbjo in prekomernimi pričakovanji do brenčečega otroka, ki je v središču pozornosti (Seidenstücker in Mautke, 2004; Scheithauer, 2014). V tem kontekstu govorita Maccoby in Martin (1983) tudi o prezaščitniški vzgoji, kjer je otrok pod stalnim nadzorom, saj starši vedo, kaj je najboljše zanj. Otrok je obsut z ljubeznijo in nežnostjo, če to želi ali ne.

Razvajanja ne moremo zamenjati z resnično čustveno pozornostjo, saj le-ta krepi otroka, pri čemer mu ob tem ponuja potrebno pomoč in držo do aktivnega spoprijemanja z življenjskimi nalogami.

Otrok živi v nerealnem svetu, pri čemer si razvije občutek, da je njegova lastna vrednost največja že zato, ker sploh obstaja. Ne nauči se bivati v skupnosti in dajati svojega prispevka. Nezavedno prekinja vzgojitelja, je brez občutka za druge. Pričakuje vse od drugih, sam pa ne zna nič ponuditi. Vedno želi biti v središču pozornosti in vedno pokvari igro, če ni po njegovem. In vedno trpi za občutkom krivice, če ni pripravljena takšna situacija, kjer bi se izkazal kot najboljši in edini (Grob in Jaschinski, 2003).

$\mathrm{Z}$ razvajajočo vzgojo vzgojitelji svojemu otroku nudijo prekomerno ljubezen. Vse zahteve in stvari, ki bi jih moral otrok narediti, so mu odvzete. Otroku ne postavljajo zahtev, svojemu potomcu izpolnijo vsako željo in se navdušujejo nad vsako njegovo potezo (Maccoby in Martin 1983).

Tudi Hurrelmann (2007) pravi, da je pri prezaščitniškem vzgojnem stilu prisotna visoka starševska avtoriteta in močna usmerjenost na potrebe otroka, kar učinkuje kot oteževanje v razvoju osebnih značilnosti in samostojnem razvoju vedenjskih kompetenc. 


\section{Participativen vzgojni stil}

Hurrelmann (2007) opredeljuje tudi participativen vzgojni stil, ki zagovarja partnerske in kooperativne kompetence v vzgojnem procesu, za razliko od permisivne naravnanosti: ne otroci, temveč starši določajo vzgojo; kakor tudi za razliko od avtoritarne naravnanosti, tukaj ne dominirajo starši, temveč odnos, ki je odprt, se usklajuje in menjuje, prisotna je usmerjenost na obojestranske potrebe, dober odnos je osnova za vzgojo, kjer so prisotne obojestranske interakcije ter skupni dogovori in usklajevanja o načinih in pravilih delovanja $\mathrm{z}$ utemeljitvami.

Tabela I: Primerjava avtoritarnega in socialnointegrativnega učitelja

\begin{tabular}{|c|c|c|}
\hline Avtoritaren učitelj & Socialnointegrativen učitelj & Kritika \\
\hline Sebe ne postavlja pod vprašaj & $\begin{array}{l}\text { Prepozna kompetence in nji- } \\
\text { hove meje }\end{array}$ & \multirow{5}{*}{$\begin{array}{l}\text { Vsak učitelj je v določenih sit- } \\
\text { uacijah tisti, ki daje navodi- } \\
\text { la, ki ukazuje, vsekakor z ute- } \\
\text { meljitvijo. } \\
\text { Četudi učenca ne dojemamo } \\
\text { kot podrejenega, ne more biti } \\
\text { vedno dojet kot enakopraven } \\
\text { partner. }\end{array}$} \\
\hline $\begin{array}{l}\text { Učence obravnava kot podre- } \\
\text { jene }\end{array}$ & $\begin{array}{l}\text { Učence sprejema kot enako- } \\
\text { pravne pogovorne partnerje }\end{array}$ & \\
\hline $\begin{array}{l}\text { Izvaja pouk po sistemu } \\
\text { vprašanje - odgovor }\end{array}$ & $\begin{array}{l}\text { Želi prispevke, sprejema pred- } \\
\text { loge, je odprt za alternative, } \\
\text { pušča odprt prostor za samos- } \\
\text { tojno delovanje }\end{array}$ & \\
\hline Ukazuje in daje navodila & Pri konfliktih išče kompromise & \\
\hline Potlači iniciative učencev & $\begin{array}{l}\text { Želi prispevke, sprejema pred- } \\
\text { loge, je odprt za alternative, } \\
\text { pušča odprt prostor za samos- } \\
\text { tojno delovanje } \\
\text { Utemeljuje lastne postopke }\end{array}$ & \\
\hline Dopušča samo posamično delo & $\begin{array}{l}\text { Razvija iniciativnost učencev } \\
\text { Razvija skupinsko in } \\
\text { posamično delo }\end{array}$ & \multirow{2}{*}{$\begin{array}{l}\text { Tudi socialnointegrativen } \\
\text { učitelj ne bo mogel biti ved- } \\
\text { no usmerjen v vsakega } \\
\text { posameznika in njegove spos- } \\
\text { obnosti. }\end{array}$} \\
\hline $\begin{array}{l}\text { Odziva se s kaznijo in destruk- } \\
\text { tivno kritiko }\end{array}$ & $\begin{array}{l}\text { Trudi se pomagati učencem } \\
\text { Zmanjšuje pritisk dosežkov ... }\end{array}$ & \\
\hline
\end{tabular}

Cilj participativne vzgoje je razvijanje samostojnosti in avtonomije, kakor tudi krepitev sposobnosti delovanja in socialne odgovornosti. Kritika participativnemu vzgojnemu stilu je ta, da je zagovornik večine, vendar preveč abstrakten za vsakdan ter brez vzora in jasne orientacije (Bauer in Einhardt, 2014).

Po Andersonu (Damm, 2014) bi lahko integrativen vzgojni stil vključili ob bok Hurrellmannovemu participativnemu, saj upošteva otrokove že- 
lje in predstave, kritika je stvarna in konstruktivna, postavijo se skupni cilji, zaželena je spontanost in otrokova aktivnost. Integrativen vzgojni stil učiteljev pri učencih izzove posnemanje. Zviša se samostojnost učencev pri pouku, aktivnosti so polnejše, ton učitelja in učencev je prijaznejši, srčen in kooperativen. Integrativen učiteljev vzgojni stil do učencev se izkazuje kot: pozornost, aktivnost, volja do dejavnosti, socialna vključenost, prepoznavanje uspešnosti, konstruktivna kritika "prave « avtoritete, toleranca, spontanost, samoiniciativnost ipd.

Ta delitev izhaja iz Levinove delitve vzgojnih stilov na avtoritarnega, demokratičnega in »laissez-faire«, pri čemer sta Tausch in Tausch preimenoval demokratičnega $\mathrm{v}$ socialnointegrativnega. Tukaj smo poenostavili in prikazujemo bipolarnost med avtoritarnim in socialnointegrativnim vzgojnim stilom, saj je »laissez-faire « upravičeno izpuščen kot popolnoma nepomemben in neprimeren pri pouku oz. $\mathrm{v}$ šoli (Riedel, 2004, str. 62).

Pri iskanju bolj diferenciranih vzgojnih stilov lahko najdemo v literaturi več različnih tipov, ki imajo manjšo mejo in so med seboj bolj prepleteni.

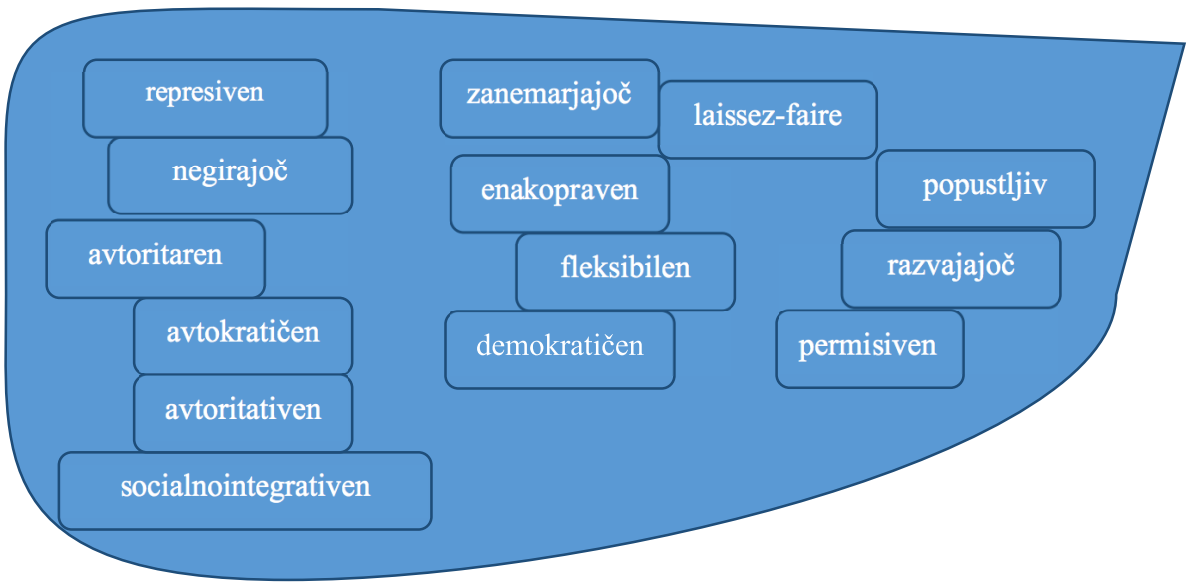

Slika I: Različna poimenovanja vzgojnih stilov (Riedel, 2004, str. 74)

Graf smo preoblikovali po Riedlu (2004), kjer smo poskusili umestiti preglednico vseh $\mathrm{v}$ prostoru pojavljajočih se terminologij.

Kritika sheme se lahko ponudi $\mathrm{v}$ nerazumljivosti pojmov avtoritaren, avtokratičen in avtoritativen, zadnji celo $\mathrm{v}$ skupnem predalčku $\mathrm{s}$ socialnointegrativnim. 


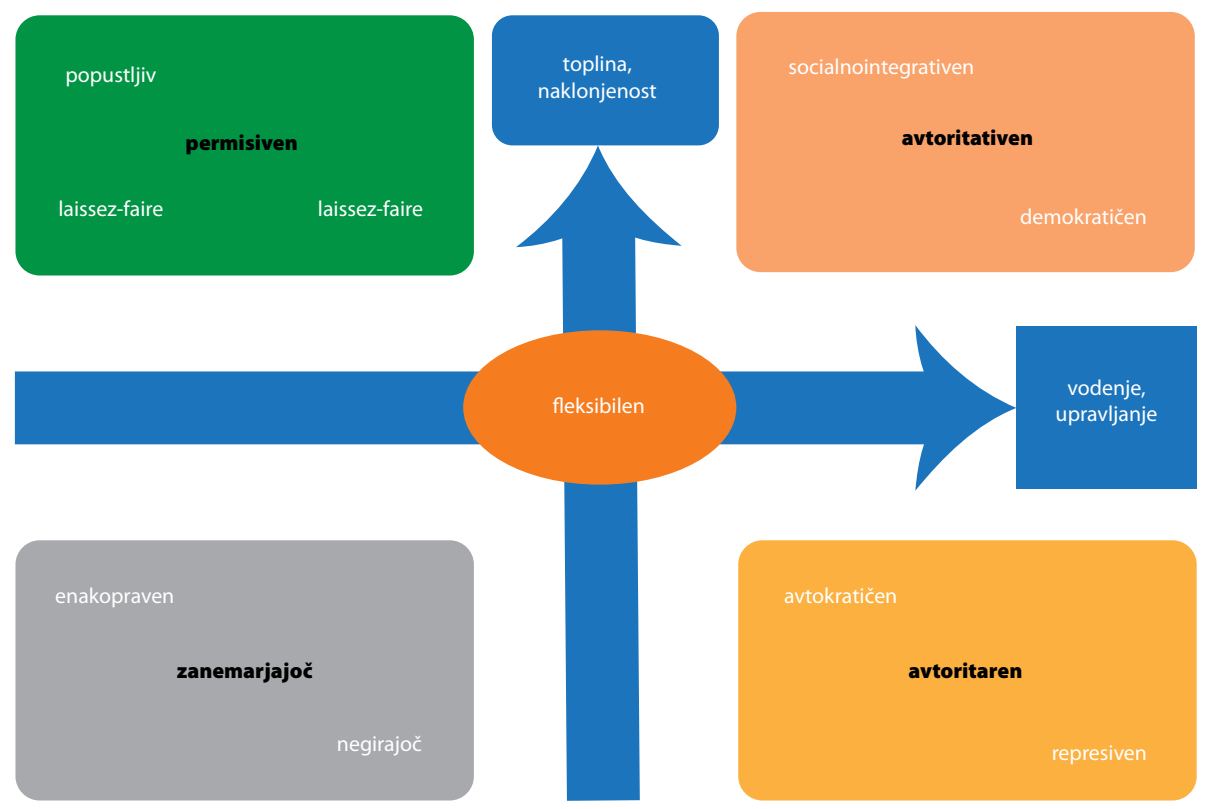

Graf I: Poskus ureditve vzgojnih stilov

Laissez-faire bi lahko dodali tudi k zanemarjajočemu vzgojnemu stilu. Ali je res prav, da otroka, ki ga imamo radi, pustimo, da dela, kar hoče?

Enakopraven stil dejansko izpričuje nekaj pomembnega, namreč različno stopnjo enkulturacije in personalizacije vzgojitelja in vzgajanca. Vsekakor ima tudi aspekte demokratičnega vzgojnega stila, čeprav ju lahko postavimo tudi v diametralen položaj.

Fleksibilen vzgojni stil vsekakor razvija primerne vzgojne ukrepe, kar je odvisno od situacije. Vendar pa to ni stil, ki bi lahko bil konstanten in dolgoročen.

Navedeni argumenti kažejo, da poskus, da bi navedene vzgojne stile uredili, zmede ne anulira.

\section{Pomen (socialno)pedagoškega odnosa}

Cilj pedagoškega odnosa sta vzgoja in izobraževanje mladih prek celote pedagoške osebe, saj se osebni duh razvija samo skozi osebnega duha. Pedagoški učinek ne izhaja iz sistema veljavnih vrednot, temveč iz prvotnega sebstva, resničnega človeka $\mathrm{z}$ resnično voljo, s katero je naravnan na 
resničnega človeka. Gre za primat vzgojne naravnanosti nasproti idejam o objektivnem in stvarnem (Giesecke, 1999).

Kot socialnopedagoški odnos označujemo vsak poseben medosebni odnos, ki nastane med socialnim pedagogom in njegovim obravnavanim otrokom oz. mladostnikom ali klientom. Vzgoja in njej podrejeni metodični repertoar morata $\mathrm{v}$ celoti potekati prek osebnega posredovanja pedagoga. Žal pa še do danes manjka prepričljiva teorija. Ta bi praksi še kako koristila, saj je pri ravnanju z otroki vse prevečkrat negotova.

Gre za obojesmerni proces dajanja in dobivanja, kjer niso samo učenci tisti, ki dobivajo, temveč je to tudi socialni pedagog. Dober stik dvigne energijo dela socialnega pedagoga, kar mu da sproščenost v delu in stopnjuje pripravljenost, da bi se čim bolj izživel in razdal.

Delo socialnega pedagoga na videz ni kaj posebnega: dela to, kar počnejo tudi vsi drugi: kuha, se pogovarja, druži, tke preproste, drobne niti, ki ustvarjajo socialnopedagoško delovno polje. Vsakdanja opravila ob interakciji z drugimi ljudmi ustvarjajo pomembno možnost tudi za ustrezno strokovno spremljanje.

Da strokovnjak lahko interakcijo nadzorovano vodi, se mora v odnosu do klienta pozicionirati v okviru šestih področij in v posamičnem primeru tudi razvijati oblike, ki ležijo znotraj naslednjih alternativ in kažejo na mešanico vedenjskih vzorcev (Giesecke, 1999).

1. Osredinjenost na naloge in osebe. Oba vidika moramo uravnotežiti in graditi osnovo za delovni pakt med klientom in strokovnjakom.

2. Simetrija in asimetrija odnosa. Oba partnerja lahko prevzameta podrejen ali nadrejen položaj in kažeta vedenjske vzorce, ki so v nasprotju z drugimi obdobji (odkar sta v odnosu). Odnos med socialnim delavcem in klientom je le redkokdaj in kratkotrajno simetričen; navadno je komplementaren. To pomeni, da so možne menjave vlog, različni, spremenljivi funkcionalni in soodvisni vedenjski vzorci.

3. Fleksibilnost in doslednost. Strokovnjak mora najti pravo mero fleksibilnosti, če želi ohranjati kakovosten odnos.

4. Prevzemanje in predajanje odgovornosti. To je močno povezano z avtonomijo posameznika; da bi klient postal avtonomen, ga mora strokovnjak motivirati, mu zaupati in omogočati osebno rast. 
5. Zadržanost in angažma. Včasih je smiselno, da na klienta sprva ne pritiskamo in smo raje bolj zadržani. Tako mu pustimo prostor za samoiniciativo, ki je lahko cilj obravnave.

6. Bližina in distanca. To je vsekakor ena od težavnejših komponent odnosa. Težko je namreč najti pravo mero bližine in distance. Če je v ospredju odnosa distanca, se strokovnjak ne more vživeti v klienta in ga zato tudi ne more celostno razumeti. Na drugi strani pa je lahko bližina problem, saj rada pripelje do odvisnosti klienta od strokovnjaka. To je eden od vzrokov za »sindrom izgorevanja«, pri čemer pride do emocionalne izčrpanosti strokovnjaka, ki se ne more znebiti te odvisnosti.

Zavedati se moramo različnih vlog in vedenjskih vzorcev, s katerimi eksperimentiramo - smo bolj ali manj direktivni, distancirani, konfrontativni ipd. Z eksperimentiranjem vlog bomo prišli do tega, kaj je v posameznem primeru najbolj produktivno.

Odnos ima v sebi tudi veliko vzgojno moč - premosti distanco, ki odtujuje socialnega pedagoga in varovanca; pojavi se domačnost in $\mathrm{z}$ njo strokovnjak varovanca potegne v smer svojega dela. Potem ko svojega klienta notranje zaposli, ta njegovo delo samodejno želi in hoče opraviti; v nasprotnem primeru bi ga doživljal kot prisilo, kot nekaj mučnega. (Prav s tem je lahko velik križ in nemalo jih ostaja na ravni discipliniranja ter opravljanja obveznosti.)

Pedagoški odnos je najnaravnejša in najpopolnejša pot do discipline. Disciplina s strahom, grožnjami, ki skriva v sebi notranji protest in težnjo po kljubovalnosti ni način, s katerim bi dosegli zastavljene cilje.

V zvezi z značilnostmi pedagoškega odnosa želimo opozoriti, da gre za sposobnosti in kvalitete, ki jih socialni pedagog mora živeti v praksi in jih ni mogoče vključevati kot kratkoročne tehnike. H. Kleinert (2007) navaja kot pomembne sestavine oz. temeljne predpostavke za pedagoški odnos naslednje značilnosti: pristnost, vživljanje, sočutje, sprejemanje, sposobnost preinterpretacije in spoštovanje.

Zakaj je potrebna kvalifikacija v vzpostavljanju odnosov? Kaj morajo socialni pedagogi vedeti in znati? Teoretično znanje je potrebno, kajti socialni pedagogi ne morejo več pridobiti usmeritev in strategij na podlagi lastnih življenjskih izkustev. Življenjska izkustva pedagogov se praviloma temeljito razlikujejo od življenjskih izkustev otrok. Tudi življenjska izkustva otrok, ko bodo odrasli, se bodo razlikovala od izkustev njihovih socialnih pedagogov. Socialni pedagogi samo na podlagi svojega življenj- 
skega izkustva nimajo na voljo dovolj obširnega znanja niti nazornih predstav o predhodnem in prihodnjem življenjskem okolju otrok. Če naj vzgoja kljub temu uspe ali če naj bo sploh mogoča, je treba to občutno pomanjkljivost odpraviti. Razlagalnih vzorcev in strategij se ne da prevzemati v standardizirani obliki, temveč jih je mogoče razvijati le v komunikaciji z otroki. »Gre za to, da se zasilna občutja in pomoč naslovnikom interpretira v okviru njihove sprejemljivosti in da se na podlagi takšnih interpretacij v komunikaciji z istimi prizadetimi razvijajo "pravilne« kakor tudi čustveno znosne utemeljitve za praktične strategije obvladovanja. Bistveno je natančno poznavanje življenjskih okoliščin otrok in seznanjenost $\mathrm{z}$ njihovimi vzorci razlaganja ter strategijami delovanja." (Dewe in Otto, 1987, str. 802). Samo z zdravim človeškim razumom in naravnim občutkom to ne bo uspelo. Zato potrebujemo poleg dobršne mere socialne domišljije še samokritično refleksivnost (Müller, 1983) in teoretično znanje, na primer o povezavah med socialnoekonomskim statusom, življenjskimi izkustvi in identiteto.

Če naj komunikacija kljub zelo različnim življenjskim izkustvom in pogosto tudi kljub pomanjkanju natančnih predstav o dosedanjem življenju otrok uspe, morajo biti na voljo sposobnosti, ki spodbujajo identiteto, predvsem distanca vlog, empatija in toleranca dvoumnosti (Wolf, 1995). To otežuje profesionalnost, kajti teh značilnosti si ni mogoče pridobiti z izobraževanjem.

Distanca vlog je »sposobnost, da se znamo dvigniti nad zahteve vlog, zato da lahko izbiramo, negiramo in interpretiramo " (Krappmann, v Wolf, 1995, str. 42). Pedagog, čigar svoboda delovanja ni tesno omejena s predpisi in majhnimi kompetencami odločanja, mora biti tudi sposoben, da to svobodo delovanja uporablja fleksibilno, primerno situacijam in individualno različno glede na potrebe posameznega otroka. Zato mora znati interpretirati svojo - tako ali tako večplastno - vlogo, ne da bi v tem odpovedal in ne da bi se pri tem okostenelo držal predpisov ravnanja za dežurnega vzgojitelja.

To je še težavnejše pri mlajših otrocih, ki vlogo svojih vzgojiteljev pogosto dojemajo kot vlogo svojih novih staršev. Tudi sosedom, prijateljem otrok ali učiteljem se ta življenjska skupnost kaže bolj kot družina. Socialni pedagogi opredeljujejo svoj položaj kot vlogo profesionalnih vzgojiteljev, hkrati pa si prizadevajo za čim večjo normalnost življenjskih odnosov in opazijo, da je za opis takega modela že pri roki izraz »družina«, ne pa denimo »stanovanjska skupina«. Tako nastaja močan vrtinec, ki poklicne pedagoge sili, naj postopoma odložijo svojo vlogo. Zato potrebujejo sposobnost 
fleksibilnega interpretiranja svoje vloge, da se ne bi pustili posrkati temu vrtincu (Müller, 2007).

Naslednja sposobnost je empatija, vživljanje. S tem pojmom moramo razumeti tako spoznavno zmožnost anticipacije doživljanja drugih kakor tudi zmožnost vživljanja v čustveni svet drugih. Čim močneje se razlikujejo življenjska izkustva socialnih pedagogov in otrok, tem večje so zahteve po empatiji, tako za uspešno sporazumevanje in ne nazadnje tudi za interakcijo $\mathrm{z}$ otroki.

Interakcija $\mathrm{z}$ otrokom, čigar vedênje socialni pedagog stalno doživlja kot »moteno", tako večinoma ni mogoča; anticipacija v tem primeru ne uspe. Pri tem anticipacija ne obsega samo napovedi vedênja - na primer v smislu »ravnokar se bo spet zgodilo to ali ono «-, temveč tudi razlago in razumevanje smisla s perspektive otroka (Wolf, 1995).

$\mathrm{Z}$ distanco vlog in empatijo se ne izogibamo različnim pričakovanjem in perspektivam. Sposobnost, da različna pričakovanja in motivacije prenašamo druge ob drugih, lahko označimo kot toleranco neskladja. V vzgojnih situacijah, kjer odrasli svoje interpretacije resničnosti ne sme represivno uveljavljati, mora biti sposoben prenašati protislovja, različne perspektive in različna občutenja (Wolf, 1995). Če mu to ne uspe, bo protislovja bodisi potlačil ali pa se bo prisiljen odreči vzgojnim aspiracijam. Institucionalna vzgoja stalno dokazuje zatiranje otrokovih interpretacij, posledica tega pa sta lažna prilagoditev in podtalnost (Goffman, 1988).

Pogosta izpostavljenost tej dvoumnosti in ambivalenci je morda ena največjih obremenitev socialnopedagoškega dela $\mathrm{z}$ ljudmi, ki imajo za seboj neobičajna življenjska izkustva, tudi zato, ker se pri tem lastno razumevanje in normalnost lastnega pogleda na svet vedno postavljata nekoliko pod vprašaj. Kdor ima - kakor pedagogi v zavodu - nenehno opraviti s tem problemom, potrebuje tudi profesionalne strategije, da bo lahko zdržal v tej dvoumnosti in je ne bo odstranjeval.

Dvoumnost je na primer odstranjena, kadar se odrečemo lastni perspektivi in se nam torej svet pokaže v enaki luči, kot ga vidi tudi otrok; vzgoja tedaj ni možna. Drug izraz odstranjevanja dvoumnosti je splošno zavračanje in zanikanje otrokove perspektive. $\mathrm{V}$ takem primeru interakcija ne uspe, pa tudi vzgoja ni možna, možni sta le lažna prilagoditev in naslonitev.

Za socialne pedagoge torej ni dovolj samo s šolanjem pridobljeno strokovno znanje, ki se posreduje in preverja s študijem in strokovnimi izpiti, ki urejajo dostop do poklica, temveč morajo imeti tudi naštete sposob- 
nosti za spodbujanje identitete. Človek si te sposobnosti pridobi v primarni socializaciji, na interakcijsko vedênje pa vplivajo tako celovito in kompleksno, da imajo konstantnost in univerzalnost osebnostnih lastnosti. Te sposobnosti so ugodne za vsakršno interakcijo in potemtakem tudi za vsa polja socialnega dela. Otroci in mladostniki se morajo izkusiti kot delujoči, postati morajo subjekt samih sebe, osvojiti morajo lastno resničnost. Socialni pedagogi morajo pripravljati in dopuščati za to potrebne in ugodne življenjske in učne razmere, v vsakdanjem sobivanju mora prek socialnih pedagogov potekati (ciljno usmerjena) vzgoja. Uspešnost vsakdana se dokazuje s tem, da sta otrokom samoumevno omogočena udeleženost in razvoj. Udeleženost vključuje tudi zavedanje, da živijo svoj vsakdan in svoje življenje, ne pa življenje ustanove ali skupine (Wolf, 1995).

$\mathrm{V}$ primerjavi s profesionalnimi dejavnostmi, ki so od vsakdana prostorsko in časovno ločene (kot na primer v svetovalnicah), je integracija $\mathrm{v}$ vsakdan posebej težka in posebej ogrožena. Thiersch (1997) opozarja na protislovne elemente usmerjenosti v vsakdan. To ne more (in ne sme) biti zavzemanje za preporod usmerjenosti v obravnavo, kaže pa, da se $z$ usmerjenostjo v vsakdan niso rešili vsi problemi. Thiersch se zavzema za razumno mero vseh dejavnikov, pri čemer je težko določiti, kakšen delež zavzema katera v tej usmerjenosti. Nedvomno velja, da naj bo usmerjenost življenjsko orientirana in prežeta s strokovnostjo v običajnem vsakdanu. Sicer je lahko problem v tem, da se uporaba strokovnega znanja v vsakdanu razgubi, saj je mogoče shajati tudi tako, da se postopoma odložijo profesionalni standardi.

Profesionalna obdelava odnosa do klientov ima še en vidik. Če se hoče socialni pedagog poglobiti v perspektivo otrok in vzeti njihova življenjska izkustva zares, mu to lahko uspe le tedaj, če ni blokiran z močnim negativnim odnosom do otrok in njihovim vrednotenjem. Takšen negativen odnos pogosto ni tako trdno zasidran, da se ga ne bi dalo spremeniti. Večinoma pa je vendarle tako tesno povezan $\mathrm{z}$ življenjskimi izkustvi socialnega pedagoga, da ga spet ni mogoče odstraniti preprosto tako, da pač socialni pedagog teh negativnih občutkov noče dopustiti. Pri tem imajo določeno vlogo tako čustveni kakor tudi spoznavni vidiki. Težko dostopni so ti odnosi tedaj, če se prek otrok sprožijo tudi hudo obremenjujoča življenjska izkustva samih socialnih pedagogov. Laže so dostopni tisti problemi, ki so v osnovi povezani z informacijskim ali izkustvenim primanjkljajem. 


\section{Kako delati metodično v ustanovi?}

Metodično delo je potrebno dojeti kot proces. In to ne kot linearni, natančen v svojem začetku, načrtovanih fazah, ampak kot neskončno spiralo, $\mathrm{v}$ katero so vključena razmišljanja in presenečenja, ki so bistvena. In pogosto si teh trenutkov in dogajanja ni enostavno pojasnjevati (Van Weezel in Waaldijk, 2007).

Povezani so $z$ dejstvi in občutji; z lastnimi cilji in izkušnjami, kot s cilji drugih ljudi in skupin, kakor tudi za čas pred samim delovanjem in po njem.

Da bi se čim bolj približali uvidu, katere namere in odločitve je potrebno sprejeti, smo izpostavili naslednje trenutke in dogajanja $\mathrm{v}$ procesu pred delovanjem in po njem. Vseh pet kategorij ima svoje vrednosti in določene možnosti ter lahko seveda tudi težave (Van Weezel in Waaldijk, 2007):

1. pojasnjevanje situacije,

2. utrjevanje ciljev,

3. izbira sredstev,

4. ocenjevanje,

5. pojasnjevanje našega lastnega angažmaja.

Pri pojasnjevanju situacij moramo zavzeti videnje $\mathrm{z}$ različnih zornih kotov. Žal diagnoza, ki jo dobimo, samo bežno pojasnjuje klientovo situacijo. Vpliv okolja, možnosti mreže, katere del je on sam, njegova zgodovina, kot tudi možnosti organizacije, naši odnosi in moje lastne možnosti - vse to je potrebno upoštevati pred nadaljnjim odločanjem, v katerega vključimo predvsem klienta. Kdo je oseba? Kakšne so njegove možnosti, kaj mu je všeč, kaj mu ni všeč itd.? Interakcija med mano in klientom. Kaj se dogaja med mano in drugim, $v$ kakšnem smislu ima kontakt $\mathrm{z}$ mano? Kakšen je moj angažma? - Jaz kot profesionalec. Prostor, v katerem živi oseba (od skupine, v katero je nameščen, do prijateljev, družine). Kaj vsi ti želijo od njega? Kaj mu lahko ponudijo? Na kakšen način različne osebe vplivajo nanj? Kakor tudi časovna perspektiva - ne samo preteklost, sedanjost, prihodnost, ampak tudi daljna preteklost in daljna prihodnost. A ima oseba pričakovanja, sanje in strahove? Kaj je naš cilj? Postavljanje ciljev je vzpostavitev akcije s konkretnostjo. Pogosto se cilji postavljajo preveč abstraktno in oddaljeno. Samo konkretni cilji se lahko prevedejo v sredstva, da so lahko naši postopki orientirani. Samo konkreten cilj, realen cilj ponudi zadovoljstvo. 
Cilji so lahko povezani z: razvojem osebe, vzpostavljanjem kontakta, atmosfero, klimo, kulturo skupine ali kulturo situacije, skupnim delom s kolegi, povezanostjo $\mathrm{z}$ družbo in odnosom do sebe, osebnim ravnovesjem, razvojem $\mathrm{v}$ delu in življenju.

Izbiranje sredstev, "načinov« poteka tako, da ko smo postavili cilj, se moramo odločiti, kako bomo delali, kako bomo izbirali sredstva, uporabljali situacije ali jih ustvarjali. Moramo najti skupen način življenja $\mathrm{z}$ našimi cilji. Naše glavno sredstvo je zavest o konkretnih možnostih v okviru konkretnih situacij. In to je $\mathrm{v}$ bistvu metodika $\mathrm{v}$ ožjem pomenu besede $-\mathrm{ki}$ nima veze $\mathrm{z}$ receptologijo oziroma $\mathrm{z}$ instrumentalisti medicine.

Nalog je nešteto in še zelo raznovrstne so. Lahko rečemo, da gre za kombinacijo dela s skupino, aktivnostmi in individualnimi kontakti. Včasih je to misija nemogoče. Pa vendar. Razlikujemo osem področij dela. Seveda spisek ni dokončen in bi se dal še izpopolniti.

Pomembna področja so: delo s skupino, gradnja in ohranjanje aktivnosti v odnosih s posamezniki, skrb v ožjem smislu - skrbeti za njih, stimuliranje aktivnosti - motivacija, stimuliranje procesa učenja, življenje s pravili, spremljanje in podpora $\mathrm{z}$ družinskimi vezmi -, kontakt $\mathrm{z}$ družino in napredovanje povezav $\mathrm{v}$ družbi.

Pomen iskrene analize, samorefleksije je zelo pomembna kategorija, kjer se moramo vprašati, kaj je s ciljem, kako smo uporabljali sredstva, kaj smo dosegli, kaj smo pozabili, kaj je šlo po načrtu in kaj se je zakompliciralo. Kaj se lahko naučimo iz tega, kaj smo naredili? Kaj so povedala naša čustva in kaj dejstva? Naša optika mora biti usmerjena $v$ posameznika, njegovo participacijo in v mreženje. Mreženje vseh subjektov, ki so zanj pomembni - posebej mislimo tukaj na učitelje, svetovalne delavce, socialno delo, svetovalne centre, zdravnike, psihiatre, kriminaliste in vse za otroka pomembne osebe.

$\mathrm{V}$ analizi se je potrebno tudi vprašati, kako sem bil angažiran. Če se naučimo biti pozorni, pazljivi na lastne postopke in občutja, bomo imeli pomemben instrument za profesionalno delo in učenje, ki sta zelo ozko povezani kategoriji (Van Weezel in Waaldijk, 2007).

Med pogoji dela moramo biti usmerjeni tudi na družbeno sredino znotraj in izven institucije ter zelo pomembno kategorijo - osnovno filozofijo institucije. Le-ta temelji na 4 načelih: vsaka oseba in institucija sta enkratni, najboljše stališče $\mathrm{v}$ tem poklicu je postavljanje vprašanj in odprtost, ta posel se ne more izvajati brez dialoga, brez resnega razumevanja druge- 
ga in njegove strani zgodbe ter radovednosti in interesov za nove metode in možnosti.

Tako se mora metodik zavedati tudi kulture lastne organizacije (Trieschman Albert, Whittaker in Brendtro, 1996):

- Kako zgodovina naše ustanove vpliva na sedanjost?

- Kateri so napotki o tem, kako se mora opravljati delo, o metodičnem delu in inspiracijskih teorijah?

- Kako so razdeljene dolžnosti, kako so formalno opisane funkcije, kakšna je avtonomija posameznika?

- Kaj lahko rečete o moči kot aspektu funkcije oz. položaja in kako so vrednotene različne vrste znanja (izkustveno - prakseološko in teoretično - osebne teorije)?

- Medsebojni odnosi? Ta postavka se lahko opazuje v odnosih med vodstvom in podrejenimi, tudi kdo je s kom v kontaktih. Kako, privatno - strokovno ipd.?

- Komunikacija? Kako so teme in informacije posredujejo na sestankih, timi - kaj je predmet razgovorov in kako poteka, kaj se zamolči, čemu se izogne ipd.?

- Katera področja dela so pomembna v tej instituciji?

- Katere naloge ta obstoječi tim vrednoti boljše in katere slabše ali celo nič?

- Kateremu področju dela je posvečeno več pozornosti, kateremu manj?

- Katero znanje/veščine so povezane $\mathrm{z}$ določeno nalogo/ciljem $\mathrm{s}$ temi otroki $v$ tej ustanovi?

Kako še biti kompetenten v metodiki? Gre za posebne sposobnosti (Trieschman Albert idr.,1996):

- $\quad$ izraziti z besedami to, kar se dogaja (!);

- $\quad$ izraziti lastne izkušnje in občutke;

- biti odgovoren za dajanje in sprejemanje feedbackov;

- pogledati na situacije $\mathrm{z}$ različnih kotov;

- $\quad$ razlagati si, kaj se dogaja in kakšne so izkušnje, s posebno pozornostjo tam, kjer se med pogledi pojavijo razlike;

- $\quad$ izogibati se trenutnim sodbam, tako pozitivnim kot negativnim (!);

- $\quad$ in žal tudi v iskanju vez in poznanstev. 
Nenazadnje še nekaj misli, pomembnih za metodiko:

- $\quad$ iskati presenečenja in nepredvidljive trenutke;

- $\quad$ komunicirati z drugimi in s sabo;

- $\quad$ pustiti, da se stvari odvijajo same od sebe. Ne bomo prišli do spoznanja, če ne vemo tu in tam ustaviti svojih prvih reakcij;

- $\quad$ sprejeti neizvesnosti. Če vse že vnaprej vemo, to naredi učenje odvečno (!);

- $\quad$ menjati stališča in sprejeti to, kar se odvija v tem trenutku. Nove informacije in drugačna stališča menjajo mišljenje. To prav tako pomeni dovoliti drugim, da se tudi oni menjajo (!).

Torej, kako postati kvaliteten metodik v vzgoji? Profesija, s katero je dovolj, da si prisoten, da si tam in da deluješ v življenjskem prostoru. To mnogokrat pomeni, poleg popite kave, še razgovor $\mathrm{z}$ mulcem, ki se vrne iz šole, $\mathrm{z}$ njim pogledati televizijo, iti v trgovino - strokovnjak ne dela nič posebnega. Člani skupine, mlajši in starejši, se večino prostega časa ukvarjajo s svojimi stvarmi. V nekem trenutku, ko jim je potrebna pomoč - ali pri domači nalogi ali ko želijo biti slišani ali ko se želijo kregati -, delavec mora biti aktivnejši.

Po drugi strani je potrebna pomoč pri oblačenju, urejanju mize ali načrtovanju izleta. Mularija še mogoče ni sposobna ali dovolj motivirana, da bi to storila sama. Obstaja veliko število dnevnih aktivnosti, ki jih je potrebno narediti. Pogosto so preveč enostavne, da bi jih izpostavljali, ampak se vsekakor morajo izvesti. Način, kako se te aktivnosti odvijajo, določa, ali se bo nekdo počutil prijetno, kot bi se naj doma, ali se vzame zelo resno ali da je poklican, da sodeluje, da nekomu pomaga, da sprejme situacijo ali da se spodbuja k obnovi prekinjenega odnosa $z$ družino (Trieschman Albert idr., 1996).

Strokovnjak mora voditi račun o svojem obnašanju, svojih reakcijah in razumeti posledice svojega vmešavanja. Tudi odločanja.

Razlike v delu avtor izpostavlja preko 3 kategorij (Van Weezel in Waaldijk, 2007):

1. biti. Enostavno, biti prisoten;

2. razmišljati, razmišljati o ljudeh, situacijah, sebi;

3. delovati, se znati vmešati, nekaj narediti, biti situacijsko ustrezno odziven. 
Delati metodično pomeni biti ozaveščen, razmišljati o tem, kaj počnemo in kaj želimo doseči. To lahko dosežemo samo tako, da naredimo razliko med našim razmišljanjem, našo prisotnostjo in našim delovanjem.

\section{Biti}

Prisotni smo na zelo različne načine:

- $\quad$ sedimo ali se sprehajamo po učilnici, skupini;

- prisotni smo s svojo pojavo in razpoloženjem;

- omogočamo prisotnost tako, da je nemogoče, da nas drugi ne opazijo, ali pa prav tako na način, da smo neopazni ipd.

Biti je termin, ki zahteva od nas, da se naučimo, da biti ni samo obstajanje, neka samo po sebi umevna trajnost, samozadostnost, samostojnost in avtonomija. Bistvo biti je v odprtosti, povezanosti z drugo osebo, občutljivosti, izpostavljenosti.

V instituciji je pomembno, da vemo, da je naša vsesplošna večna prisotnost lahko tudi velik hendikep, saj otroka/mladostnika onemogočamo v njegovi samostojnosti.

\section{Delovati}

Delovati pomeni mnogo več, kot samo delati neke stvari. Delovanje je vedno znova začetek nečesa novega, nepredvidljivega. Opozorili bi na besede trud, delo in delovanje. To je opozorilo na težko dojemanje tovrstnega dela na preveč tehnicističen način. Delo z ljudmi je specifična uganka. Tudi majhen dogodek ima lahko dolgoročne posledice. Vedno ne moremo vedeti, kaj bo naš postopek proizvedel. Vsekakor pa želimo predvideti, kaj delamo. To je metodično delo. Mollenhauer (2008) pravi, da takrat, ko želimo biti sigurni, naredimo model situacije preko svoje moči, namesto, da bi delovali v sami situaciji. Zaradi enkratnosti ljudi je vsaka situacija enkratna in izhod neizvesten. Vedno znova odkrivamo, da naša predvidevanja ne funkcionirajo.

Zavest o razliki med modeliranjem situacije in delovanjem, vključujoč tudi tisto, kar se ne more predvidevati, ne kot neuspeh, temveč kot stvarnost in koristnost $\mathrm{v}$ dialogu $\mathrm{z}$ ljudmi, je pomembna, predvsem ko želimo, da sobivajočega razumemo resno, globoko prepričani, da vsak živi svoje življenje udeležen v družbi na svoj lasten način. 
Ne moremo prevzeti življenja nekoga drugega, niti ne kaže, da bi to poskušali. Ker se v našem institucionalnem delu pojavi kontakt, ki je v veliki meri odvisen od nas, se počutimo za njih odgovorne, kar poveča nevarnost, da prevzemamo njihovo življenje v svoje roke.

$V$ metodičnem delu vedno obstaja tenzija med zavestnim delom in poskusom predvidevanja, kaj bo naredil tisti z druge strani. Iz najboljše želje do drugega mi pravzaprav že predvidevamo njegovo lastno udeležbo. Te odprtosti moramo biti ozaveščeni, da bi se lahko izognili iskanju receptov ali teorij, ki eliminirajo tiste, ki jim želimo pomagati. Vedeti zagotovo, kaj se bo zgodilo, se sliši zelo privlačno, sicer pa je to velika zabloda.

Delo z ljudmi je torej vedno mešanje v njihovo življenje, zato zahteva $\mathrm{v}$ bistvu vedno odprt dialog. Ker bi samo to seveda bilo premalo in bi skorajda že temeljilo samo na občutku, spontanosti in intuiciji, je potrebno, da smo profesionalni. Zato je potrebno razmišljati in analizirati to, kar se dogaja, kar je pomemben del metodičnega dela (Van Weezel in Waaldijk, 2007).

\section{Razmišljati}

$\mathrm{V}$ tem delu sodeluje veliko ljudi in pogosto dobimo od njih veliko število nasprotujočih si signalov. Kako jih analizirati? Kako jih oceniti? Najprej se moramo naučiti razlikovati, kaj se dogaja. Sredstva, s katerimi razumevamo dogajanje in s katerimi razmišljamo $\mathrm{v}$ dani situaciji, morajo izboljšati naš profesionalni razvoj. Vedno obstaja več, kot vidimo in opažamo. Lahko la začnemo razmišljati o tem, kaj smo videli in opazili, in potem vprašamo sebe in druge, kaj so doživeli in opazili. Pomembno je sprejeti dejstvo, da so nam drugi ljudje pomembni za razmišljanje, za raziskovanje situacije, da bi lahko razumeli ozadje tega, kar se dogaja, in to je proces, ki nima konca. Zato se metodično delo lahko izvaja samo skozi dialog (Van Weezel in Waaldijk, 2007).

Profesionalno delo ne vsebuje samo delovanja k cilju otroka, oskrbovanca, da dobi ustrezno vzgojno pomoč, ampak, da se spoštujejo tudi njegove pravice. Otrokove pravice so izjemno pomembna kategorija, o kateri teče posebej na področju izvendružinske vzgoje živahna razprava (Freire, 2017).

\section{Kako je z vzgojno receptologijo?}

Böhm (1995, str. 9) v svoji knjigi Teorija in praksa o vzgoji poudarja, da željo po receptologiji in tehnokratizaciji vzgojnih znanosti lahko pozabimo, 
saj ne moremo dati nobenega praktičnega pravila, ki bo primeren za vsak primer posebej in bi bil podan enkrat za vselej. Receptologija onemogoča vzgojo, ki temelji na človeških pojmih, kot so svoboda, svobodna volja, odločitve, kreativnost, izbira, vedenje, doslednost, odgovornost itd., tako pri vzgajanih kot vzgojiteljih.

Vzgojo zato lahko predstavimo zgolj kot oseben odnos med starejšimi in mlajšimi generacijami, pri katerih poskušajo prvi namerno in načrtovano usmerjati mlade $\mathrm{k}$ ustreznemu delovanju in življenju v obstoječi kulturi, tako da je rastoča generacija $\mathrm{v}$ položaju, da bo lahko odgovornost samostojno razvijala naprej (Böhm, 1995, str. 23).

Praktiki imajo pogosto napačna pričakovanja od teorije: nadejajo se, da bodo dobili jasna pravila in rešitve za pedagoške postopke glede na vzgojni problem, na katerega so naleteli Altenthan idr. (2012). Zaradi značaja univerzalnosti ni nobena teorija v stanju, da bi ponujala recepte. Avtorji (str. 33) nadaljujejo s tezo, da se teorija in prakse na smejo obravnavati ločeno. Že od samega začetka delujeta obe kategoriji vzajemno in nista neodvisni druga od druge. S pomočjo znanstvene teorije se lahko napovedujejo vedenjski načini in situacije, napotki k delovanju v vzgoji, da bi jih lahko vzgojitelj reflektiral. Znanstvena dognanja so lahko v orientacijsko pomoč pri vzgoji v zelo konkretnih situacijah, saj brez njih obstaja nevarnost, da se posredujejo subjektivne oz. domače teorije, ki se praviloma ne ujemajo z realnostjo. Zaradi splošne veljavnosti ni nobena teorija v stanju, da bi zagotovila receptologijo. Lahko ponudi le splošna navodila, ki morajo biti »prevedena« za vsak primer posebej (Spajić Vrkaš, 2001).

Receptologija v vzgoji popači in omeji proces razumevanja in tisto, čemur rečemo izkušnja, tako se zreducira v nereflektiran razplet.

Avtorji lahko pomagajo v vzgoji z nasveti, kako naj si vzgojitelji pridobijo lastna spoznanja, ne pa da bi predstavljali že pripravljene »recepte«. Vzpodbujajo k analizi lastnih strategij reševanja problemov ter oblikovanju lastnih rešitev (Jahn, 2012).

Prav tako se vsi recepti lepo slišijo, ponujajo neko navidezno oporo, ki se v konkretni realnosti izjalovi. Avtorica (Jahn, 2012) navaja, da receptološki napotki pogosto orientirajo na nerealne in nedosegljive ideale. Vzgoja se mora sprejeti tudi s strani svetovalcev kot kontingent možnih reakcij vseh udeležencev. Recepti ne obstajajo (str. 82).

V vzgoji obstaja tudi skeptičen trenutek, ki vključuje tudi možnost neuspeha. V tem smislu veda ne more ponuditi natančnih navodil ukrepanja 
in delovanja, temveč samo razpravo o alternativah in upoštevanju načel, ki bi jih lahko uporabili.

\section{Sklep}

Dejstvo je, da se po mnogih državah profesionalci trudijo, da pomagajo mladim, da živijo svoja življenja, ne glede na to, kako težke so zunanje ali notranje prepreke. Ukvarjajo se z razumevanjem mladih, njihovimi najintimnejšimi občutji, njihovo osebno zgodovino, načrti za prihodnost, njihovo mrežo odnosov. Prav tako, da pomagajo mladim, da rešijo težave in/ ali da jih prvenstveno naučijo živeti s njihovimi primanjkljaji, da najdejo pravo ravnotežje, načine vključevanja, med sistemom in osebno angažiranostjo in kreativnostjo, med napredovanjem posameznika in njegove mreže (družine itn.), kakor tudi, da razvijajo intenzivno sodelovanje z drugimi službami pomoči, z drugimi disciplinami. Končni kriterij je mnogo višji v praksi in v dejanski kvaliteti življenja kot v teorijah in abstraktnih principih.

Refleksija in strokovno argumentiran pristop nam dajeta vpogled $\mathrm{v}$ delovanje, usmeritev in oceno. Profesionalni vzgojitelj mora vedno znati sebi in drugim strokovno argumentirati svoje delo.

$\mathrm{V}$ pomoč kvalitetni vzgoji je kontroliran pedagoški odnos, ki temelji na spoštovanju in iskreni ljubezni do vzgajanih. Naše delo v odnosu bo toliko bolj plemenito, kolikor bolj se bomo zavedali osebnih kvalitet, svoje osebnostne specifike in svojih metodičnih spretnosti in vloge. Refleksija vodenja odnosa, rasti v njemu, vseh čeri, ki se pojavljajo v pedagoškem procesu, in kriteriji nadzorovanja odnosa so pomembni gabariti pri socialnopedagoškem delu.

Opredelili smo tudi vzgojne stile, ki se pogosto pojavljajo v medijih kot tisti ključni, v skorajda apokaliptičnem propadu človeštva, na račun takšnih mladih, kot smo jih ustvarili. Termini vzgojnih stilov tako dobivajo nova imena, nekateri starejši termini, ki so bili v prejšnjem obdobju poimenovani kot edini ustrezni, so sedaj neustrezni in podobno. Naša namera je bila sistematično jih razvrstiti in osvetliti, da ni čistega vzgojnega stila, ${ }^{8}$ ampak da je pomemben tisti vzgojni stil, ki posameznika spoštuje, je human in učinkovit.

Prispevek zaključujemo z večno dilemo: Kaj učinkuje? To, kar je za nekoga zdravilo, je za drugega strup. To, kar lahko jaz naredim vzgojno učin-

$8 \quad$ Kakorkoli bi ga že poimenovali. 
kovitega, kolegica ali kolega v takšni meri oz. tolikšni intenziteti ne uspeta, kakor tudi jaz ne tistega v tolikšni meri in takšni intenziteti kot lahko kolegica ali kolega.

Zato se ne kaže ukvarjati z receptologijo v vzgoji, kakor tudi ne $z$ leksikonom nasvetov, ki so primerni za to ali ono priložnost, za takšnega ali drugačnega otroka. Absolviranje teoretskih diskurzov stroke, poznavanje otroka, skrb za razumevanje njegovih vedenj, odnos in oblikovana osebnost vzgojitelja so nekatere bistvene premise, ki bodo zagotavljale večjo verjetnost vzgoje, ki bo imela pogum, da bo usmerjala in kazala na svojem primeru zadovoljnega in odgovornega posameznika.

\section{Literatura}

Altenthan, S., Betscher-Ott, S., Gotthardt, W., Hermann, H., Höhlein, R., Ott, W., ... Hobmair, H. (2012). Pädagogik (5. Auflage). Köln: Bildungsverlag EINS.

Bauer, P., in Einhardt, M. (2014). Perspektiven sozialpädagogischer Beratung. Weinheim, Basel, Berlin: Beltz Juventa Verlag.

Baumrind, D. (2008). Authoritative parenting for character and competence.

V D. Streight (ur.), Parenting for character: Five experts, five practices (str. 17-32). Portland, OR: CSEE.

Böhm, W. (1995). Theorie und Praxis: Eine Einführung in das pädagogische Grundproblem. Würzburg: Königshausen \& Neumann.

Brezinka, W. (2017). Education and pedagogy in cultural change. New York, NY: Routledge.

Buchmann, M. (2007). Stadien der Kindheit, der Adoleszenz und des späten Jugendalters: Schweizerischer Kinder- und Jugensurvey COCON. Werkstattbericht: ch- $x, 18,22-23$.

Buchmann, M. (2014). Die pädagogische Fachkraft und Professionalität: Wie mit Hilfe der Schemapädagogik extreme Erziehungsstile identifiziert und überwunden werden können. Stuttgart: Ibidem Verlag.

Dewe, B., in Otto H. U. (1987). Verwissenschaftlichung ohne Selbstreflexivität - Produktion und Applikation wissenschaftlicher Problemdeutungen in der Sozialarbeit/Sozialpädagogik. V T. Olk in H. U. Otto (ur.), Soziale Dienste im Wandel - I. Helfen im Sozialstaat (str. 287-326). Neuwied und Darmstadt: Luchterhand.

Freire, P. (2017). Pedagogija autonomije. Beograd: Clio. 
Fritsch, G., in Ockhardt, S. (2010). Ein Land im Wandel der Erziehungsstile. München: GRIN Verlag GmbH.

Gerr, H. E. (2014). Kreativität und Unterrichtgestaltung. Hamburg: Diplomica Verlag.

Giesecke, H. (1999). Die pädagogische Beziehung. Pädagogische Professionalität und die Emanzipation des Kindes. Weinheim, München: Juventa.

Giroux, H. (2013). O kritičkoj pedagogiji. Beograd: Eduka.

Goffman, E. (1988). Azili. V V. Flaker in M. Urek (ur.), Hrastovški anali za leto 1987 (str. 73-137). Ljubljana: RK ZSM Slovenije.

Grob, A., in Jaschinski, U. (2003). Erwachsen werden: Entwicklungspsychologie des Jugendalters Gebundene Ausgabe. Weinheim, Basel, Berlin: Beltz Juventa Verlag.

Gutzwiller Helfenfinger, E. (2015). Die Wirkung von erweitertem Rollenspiel auf soziale Perspektivenübernahme und antisoziales Verhalten. V T. Malti in S. Perren (ur.), Soziale Kompetenz bei Kindern und Jugendlichen (2. überarb. und erw. Aufl.) (str. 244-261). Stuttgart: Kohlhammer.

Hurrelmann, K. (2007). Lebensphase Jugend (Adolescence as a phase of life) (9. Auflage). Weinheim: Beltz Juventa.

Hurrelmann, K., in Bauer, U. (2015). Einführung in die Sozialisationstheorie: Das Modell der produktiven Realitätsverarbeitung Taschenbuch (11. Auflage). Weinheim: Beltz Verlag.

Jahn, S. (2012). Eine Analyse der elterlichen Implementierung von pädagogischen Argumentationen in den Erziehungsalltag. (Inaugural-Dissertation zur Erlangung des Doktorgrades Dr. phil. der Pädagogischen Hochschule Weingarten).

Kleinert, H. (2007). Methoden der Frühpädagogik: Ideenbörse. Pridobljeno s http://www.rahmenplan.de/R61.html

Kohn, A. (1999). Punished by rewards. Boston, MA: Houghton Mifflin Company.

Levin, K. (2012). Feldtheorie in den Sozialwisenschaften: Ausgewählte theoretische Schriften. Bern: Hans Huber Verlag.

Maccoby, E. E., in Martin, J. A. (1983): Socialization in the context of the family: Parent-child interaction. V E. M. Hetherington (ur.), Handbook of child psychology: Vol. 4: Socialization, personality, and social development (str. 1-101). New Jersey: Wiley.

Mollenhauer, K. (2008). Vergessene Zusammenhänge: Über Kultur und Erziehung. München, Weinheim: Juventa Verlag. 
Müller, A. (1983). Integrative und integrierte Bewegungserziehung im Sozialisationsfeld Heimerziehung. Eine Fallstudie. V E. Knab (ur.), Heimerziehung - ein differenziertes Leistungsangebot (str. 79-106). Frankfurt/M: Peter Lang.

Müller, B. (2007). Nähe, Distanz, Professionalität. Zur Handlungslogik von Heimerziehung als Arbeitsfeld. V M. Dörr in B. Müller (ur.), Nähe und Distanz. Ein Spannungsfeld pädagogischer Professionalität (str. 141-159). Weinheim, München: Juventa.

Riedel, H. (2004). Grundgedanken der Systemischen Didkatik. V M. Lansky in I. Fiolova (ur.), Bildungskybernetik in Forschung und Lehre (str. 51-92). Praga: Kava-Pech.

Russell, T., in Loughran, J. (2007). Enacting a pedagogy of teacher education: Values, relationships and practices. London: Taylor \& Francis.

Satow, L. (2013). Eltern - Erziehungsstil Inventar. Pridobljeno s http://www. zpid.de/pub/tests/9006582_EEI-Testdokumentation.pdf

Scheithauer, H. (2014). Elterliche Erziehungsstile und Förderung emotionaler und sozialer Kompetenzen von Kindern. Vortrag auf dem Fachsymposium "Jeder Tag ist Elternabend! Eltern gewinnen, Partnerschaften stärken, Kinder fördern«. Augsburg: Papilio.

Seidenstücker, B., in Mautke, B. (2004). Praxisratgeber Kinder-und Jugendhilfe. Merching: Forum-Verlag Herkert.

Spajić Vrkaš, V. (2001). Obrazovanje za ljudska prava i demoraciju: Zbirka međunarodnih dokumenata. Zagreb: Hrvatsko povjerenstvo za UNESCO i Projekt Obrazovanje za mir i ljudska prava za hrvatske osnove škole.

Tausch, R., in Tausch, A-M. (1998). Erziehungspsylogie. Begegnung von Person zu Person. Göttingen, Toronto, Zürich: Hogrefe Verlag für Psychologie.

Thiersch, H. (1997). Lebensweltorientierung konkret. Jugendhilfe auf dem Weg zu einer veränderten Praxis. V M. Wolff, W. Schröer in S. Möser (ur.), Lebensweltorientierung konkret - Jugendhilfe auf dem Weg zu einer veränderten Praxis (str. 14-28). Frankfurt/M: IGfH.

Trieschman Albert, E., Whittaker, J. K., in Brendtro L. K., (1996). The other 23 hours, Child care work with emotionaly disturbed children in a therapeutic milieu. Chicago, IL: Aldine Publishing Company.

Van Weezel, L. G., in Waaldijk, K. (2007). Kako raditi metodično u institucionalnim okruženjima. Beograd: FICE Srbija.

Wexberg, E. (1998). Moralität und psychische Gesundheit. Frankfurt am Main: Fischer-Taschenbuch-Verlag. 
Wolf, K. (1995). Veränderungen der Heimerziehungspraxis. Die großen Linien. V K. Wolf (ur.), Entwicklungen in der Heimerziehung (str. 12-65). Münster: Votum Verlag. 


\title{
Razumevanje in opredeljevanje čustvenih in vedenjskih težav in/ali motenj v polju vzgojnih zavodov
}

\author{
Mateja Marovič \\ OŠ Veržej - enota DOM, \\ Univerza na Primorskem, Pedagoška fakulteta
}

\section{Uvod}

Schultheiss že leta 1974 (v Metljak, Kobolt in Potočnik, 2010, str. 91) postavi še danes veljavno tezo: »Termini na tem področju odslikavajo družbeno razumevanje otrok in vzgoje, značilno za neko zgodovinsko dobo. «

$\mathrm{V}$ toku zgodovine je tako razumevanje populacije - drugačne od zaželenih družbeno pogojenih norm določenega časa, kot tudi z njo povezano izrazoslovje - zaznamovano s prevladujočimi paradigmami takratnega časa. Opredelitve se sicer skozi čas in prostor spreminjajo (Razpotnik, 2011). Izraze: zanemarjena, težje vzgojljiva, ubožna mladina, kot tudi izraz motnje vedenja in osebnosti nadomestijo izrazi: otroci/mladostniki s čustvenimi in vedenjskimi težavami/motnjami, otroci s težavami v socialni integraciji, moteči otroci, otroci $z$ izstopajočim vedenjem idr., vendar pa si tudi glede slednjih avtorji danes niso enotni. Zdi se, da so poimenovanja kot tudi že obstoječe klasifikacije »dekontekstualizirana in brez prave refleksije ter izražajo prej ostanke nekih prejšnjih diskurzov /.../ ter inercijo različnih ustanov in paradigem, da bi ohranile svoja polja delovanja ne glede na spreminjajoče se družbene razmere.« (str. 103). Prizadevanja socialnopedagoške stroke, »da bi se poimenovanja, ki se v določenem času in prostoru uveljavijo za označevanje posameznikov, katerih vedenje je predvsem

1 Prav tako termini, ki jih za opredeljevanje določene populacije uporabljamo, odsevajo kontekst, "v katerem opazujemo ali izkušamo posamezna vedenja in predsodke, ki jih do njih gojimo« (Leone, v Kosmač, 2007, str. 386). 
znotraj vzgojno-izobraževalnih kontekstov znano kot moteče, reflektirala, spreminjala in širše odražala kompleksno problematiko, v kateri se določeno vedenje pojavlja« (str. 105), ter vse glasnejši apeli, ki v zadnjih letih izhajajo iz neposrednega dela strokovnih delavcev ter njihovega zaznavanja značilnosti omenjene populacije v vzgojnih zavodih (v nadaljevanju: VZ), pa ostajajo »Z vidika zakonodajalcev ter drugih strok preslišani« (str. 105).

Terminološko zmedo ${ }^{2} \mathrm{v}$ zvezi s poimenovanjem populacije nameščene v VZ je tako zaznati v številnih pravno veljavnih dokumentih (Bela knjiga o vzgoji in izobraževanju v Republiki Sloveniji (v nadaljevanju: BKVIZ), 2011; Zakon o usmerjanju otrok s posebnimi potrebami (v nadaljevanju: ZUOPP-1), 2011 idr.) kot tudi v okviru socialnopedagoške doktrine razumevanja omenjenega opredeljevanja, ki je s populacijo s čustvenimi in vedenjskimi težavami in/ali motnjami (v nadaljevanju: ČVT/M) najbolj neposredno povezana (Kobal Tomc idr., 2011; Kobolt, 2011; Krajnčan, 2010; Marovič, 2017; Myschker, 2009 idr.).

Čeprav je terminologija poimenovanja določenega dela populacije $\mathrm{v}$ večini (sicer) domena stroke, ki se $\mathrm{z}$ njo profesionalno ali znanstveno ukvarja, pa tudi znotraj ožje socialnopedagoške doktrine, ki je z opredeljevanjem omenjene populacije najbolj usodno povezana, teorija in praksa velikokrat ne zavzemata istih stališč.

Enotnih kriterijev, ki bi hkrati zajemali vse specifike znotraj različnih raziskovalnih področij opredeljevanja ČVT/M, tako skorajda ni mogoče izoblikovati. Zato še vedno, kot že pred slabimi tridesetimi leti, ostaja nesporno dejstvo, da so opredeljevanje, obravnava in tudi razumevanje disocialnosti otrok in mladostnikov ter z njimi povezana terminologija kot bo razvidno v nadaljevanju - nekatera izmed tistih področij, »ki jim tudi današnja razvitost različnih strok ni kos v taki meri, kot bi si to želeli.« (Bečaj, 1987, str. 9).

2 Tudi Myschker (2009) zapiše, da sta analiza pojma in terminološka določitev le-tega - gledano z internacionalnega vidika - nedoločena. Stališče opredeljevanja ČVT/M ostaja (tako kot prej) enako, kot je pred časom zapisal priznani ameriški socialni pedagog Kaufmann (v Myschker, 2009): »Dejstvo je, da je terminologija na tem področju pogosto tako zavajajoča, kot so otroci in mladostniki, katerim oznake opredelitev pripisujemo.« Zato ne preseneča, da se, ko govorimo o ČVT/M, »srečujemo z izrazi, ki nakazujejo velike razlike v pristopih in v razumevanju.« (Metljak idr., 2010, str. 88). 


\section{Pregled nekaterih opredelitev ${ }^{3}$ čustvenih in vedenjskih težav in/ali motenj}

Značilnosti težav in odklonov $\mathrm{v}$ opredeljevanju vedenja otrok in mladostnikov v polju razumevanja ČVT/M ter poskusi definiranja le-teh se v nadaljevanju izražajo v ugotovitvah različnih avtorjev, pri katerih iz svoje profesionalne usmerjenosti izhajajo. Definicije, ki sledijo, omogočajo poglobljeno razumevanje otrok/mladostnikov s ČVT/M in so več ali manj prisotne tudi $\mathrm{v}$ praksi delovanja slovenskih $\mathrm{VZ}$, hkrati pa nakazujejo na protislovnost pojmovanj ter kompleksnost problematike, ki se (kot že izpostavljeno) razprostira na kontinuumu terminološke in definicijske nedorečenosti omenjene populacije.

Čustvene, vedenjske in socialne težave, tako D. Zorc Maver (2010, str. 24), lahko razumemo kot "nezadovoljivo ujemanje med osebo in okoljem, ki prizadene osebo in/ali njeno okolje«. Lahko pa, tako Š. Byrne (2010, str. 32), gledamo nanje »kot na socialni konstrukt, saj je definiranje vedenja kot težavnega odvisno od socialnih in kulturnih pričakovanj, prepričanj in kontekstualnih faktorjev.« (prim. Kobolt, 2011; Kosmač, 2007; Myschker, 2009 idr.). So tesno povezane $s$ »socialnim kontekstom, na katerega se sleherni človek odziva na osnovi značilnosti svoje percepcije socialnega konteksta, svojih preteklih izkušenj in sedanjih pričakovanj, doživljanja lastne socialne umeščenosti in socialnega položaja, ki ga zavzema v različnih socialnih okoljih.« (Metljak idr., 2010, str. 89).

Po Bronfenbrennerjevem ekološkem modelu (Svetin Jakopič, 2005) sta tako posameznikov razvoj, kot posledično tudi nastanek in razvoj psihosocialnih (vedenjskih) motenj, odvisna od celotnega življenjskega sistema, ki ga tvorijo: otrok sam; mikrosistemi (družina, prijatelji, šola ipd.); mezosistemi (interakcije med mikrosistemi); ekosistemi (lokalne šolske oblasti, so-

3 Opredelitve, objavljene pred letom 2007, v večini izhajajo iz zakonsko opredeljenega termina, aktualnega za takratno obdobje, in sicer motnje vedenja in osebnosti. Termine puščamo $\mathrm{v}$ prvotnem izrazoslovju predvsem zaradi razvidnosti, da se definicije ČVT/M kljub spremembi terminologije niso spremenile, temveč lete ostajajo $\mathrm{z}$ dopolnitvami ter ugotovitvami posameznih avtorjev $\mathrm{v}$ svojem bistvu identične slednjim. Tako še vedno ohranjajo iste razlagalno vsebovane komponente, kljub temu da so se krovni termini preimenovali. Če poenostavimo: tisto, kar je še pred časom veljalo za opredelitve populacije z motnjami vedenja in osebnosti, velja danes (z rahlimi posodobitvami in spremembami izrazoslovja) za opredelitve populacije s čustvenimi in vedenjskimi težavami in/ali motnjami. Razlika je tako opazna le v izrazoslovju, ki nakazuje premik k manj stigmatizirajočemu diskurzu razumevanja omenjene populacije, niso pa se, kot že Opara idr. (2010), spremenili kriteriji. 
cialna politika ipd.); makrosistemi (ideologija, vrednote, kultura, vedenjski vzorci naroda, socialnega razreda, etnične skupine ipd.).

Krajnčan in Škoflek (200o) vedenjske in osebnostne motnje razumeta kot pojavnosti, ki so si od vseh razvojnih motenj - kot so motnje v duševnem razvoju, gluhota, govorne motnje, slepota in gibalna oviranost - najmanj podobne oziroma enotne. Pravita, da imajo le-te, bolj kot vse razvojne motnje, skoraj vsaka

"svoj specifičen splet vzrokov za nastanek in patogeni razvoj, pa tudi verjetnost oziroma intenzivnost njihovega pojavljanja ni povsem predvidljiva, saj je tudi bolj kot vse ostale razvojne motnje odvisna od otrokovega/mladostnikovega trenutnega psihofizičnega stanja, senzibilnosti trenutnega okolja za odklonsko vedenje ter interaktivnih spodbud (med okoliščinami in otrokom/mladostnikom).« (str. 168)

Bečaj (2003) zapiše, da so motnje vedenja in osebnosti posebna oblika disocialnosti, povezane $\mathrm{z}$ motenim čustvenim razvojem. Ugotavlja, da »pri takem otroku oz. mladostniku lahko ugotovimo značilno disfunkcionalnost na vseh življenjskih področjih, kar je posledica specifične organiziranosti osebnostne strukture. Ne gre torej za to, da otrok s svojim disocialnim ravnanjem prihaja $\mathrm{v}$ konflikte $\mathrm{z}$ okoljem le $\mathrm{v}$ določenem okviru ali le na določenih področjih in situacijah, medtem ko je drugod normalno prilagojen« (str. 16), temveč v konflikte prihaja povsod. ${ }^{4}$

Redl in Wineman (1984) motnje vedenja ter čustvovanja otrok/mladostnikov - pri čemer izhajata iz psihoanalitične teorije - razlagata preko slabe razvitosti otrokovega/mladostnikovega »kontrolnega sistema", in sicer kot motnjo ega in nerazvitost superega ${ }^{5}$.

4 Temeljne posebnosti omenjene populacije, kot nadaljuje avtor, se izražajo v: nizki frustracijski toleranci, slabem nadzoru nad svojim vedenjem, nestrukturiranosti, kratkotrajni motivaciji, težavah na področju čustvovanja, težavah na področju socialnega vedenja, ki so povezane zlasti s strahom pred zavrnitvijo, negotovosti vase, strahu pred rivalitetnimi situacijami in neuspehom ipd. (Bečaj, 2003). Kot osrednjo težavo Bečaj izpostavi slabo samopodobo, za katero pravi, da je z zunanjim vedenjem uspešno prekrita. Tak otrok navzven deluje kot predrzen in agresiven, zaradi česar okolje njegove negativne samopodobe praviloma ne prepozna (Bečaj, 2003; prim. Skalar, 2003; Svetin Jakopič, 2005).

5 Superego, ki pomeni več ali manj isto kot vest, nas spominja na vrednote, ki so del vsakdanjega življenja. Za ego predpostavljamo, da nas bo vodil v skladu z realnostjo. V vsaki situaciji deluje več delov osebnosti, pri čemer je naloga ega skrb za koordinacijo, kar pomeni, da odloča, koliko naj na osebnost vplivajo zahteve impulzivnega sistema, koliko zahteve zunanje realnosti ter koliko lastna zavest. Uravnoteženo 
Skalar (2003) meni, da so otroci s čustvenimi in vedenjskimi težavami, ki jih enači z otroki z motnjami vedenja in osebnosti ter otroki s težavami v socialni integraciji, »otroci, ki s svojim vedenjem ogrožajo same sebe, svoje življenje in zdravje, svojo osebnostno in socialno integriteto, in pa otroci, katerih vedenje je ogrožajoče za socialno okolje, ker je uperjeno proti pravilom, vrednostim in vrednotam, tudi proti veljavnim moralnim normam in zakonom « (str. 9). Pravi, da v »kategorijo s čustvenimi in vedenjskimi težavami uvrščamo samo otroke, pri katerih predstavljajo neustrezni vedenjski vzorec trajnejša in hujša odstopanja od vedenjskih vzorcev, značilnih za otroka v določenem časovnem obdobju« (str. 9; prim. ZUOPP-1, 2011; Mednarodna klasifikacija bolezni (v nadaljevanju: MKB-10), 2005).

Metljak idr. (2010) v prispevku z naslovom Narava vedenjskih, čustvenih in socialnih težav se izmika definicijam, na temeljih izčrpnega pregleda predvsem tuje (anglosaške) literature, kot najbolj smiselna termina za poimenovanje čustvenih in vedenjskih težav in razlago le-teh izpostavijo: ${ }^{6}$

- socialnointegracijske težave, s katerimi poudarijo »težavo, ki jo ima posameznik (saj ne zanika individualne ravni ali dimenzije), in vpelje socialno, družbeno, skupinsko, okoljsko raven, ki je z nastajanjem in vzdrževanjem tovrstnih težav usodno povezana" (Metljak, 2010, str. 89);

- čustvene, vedenjske in socialne težave/motnje - $\mathrm{z}$ izrazom opozorijo, »da se težave pojavijo na enem, dveh ali vsaj treh področjih, najpogosteje pa so soodvisne in druga drugo vzdržujejo« (Metljak, 2010, str. 89).

Če izhajamo iz aktualne šolske zakonodaje - natančneje iz ZUOPP-1 (2011), s katerim se je skupno s sprejetjem univerzalnega naziva otroci s posebnimi potrebami (v nadaljevanju: OPP) začela spreminjati zakonska regulativa za populacijo OPP - opredeljuje le-ta kot eno izmed kategorij otroke šcustvenimi in vedenjskimi motnjami. Omenjeno kategorijo poimenuje:

"Otroci s čustvenimi in vedenjskimi motnjami so otroci $z$ disocialnim vedenjem, ki je intenzivno, ponavljajoče se in trajnejše ter se

osebnost torej predstavlja pravilna koordinacija vseh zgoraj omenjenih sistemov, za katero skrbi ego. Delinkventni ego pa daje prednost impulzivnosti ali superegu.

6 V podpoglavju Spekter opredelitev čustvenih in vedenjskih težav/motenj zgoraj navedeni avtorji uporabljajo termin čustvene, vedenjske težave in socialne težave, "vendar z zavedanjem, da je to izraz posplošitve, da ostaja kategorialna nalepka, ki ne odraža enkratnosti in posameznih, lahko zelo raznolikih značilnosti tako posameznika kot njegove socialne umeščenosti.« (Metljak idr., 2010, str. 93) 
kaže z neuspešno socialno integracijo. Otrokovo disocialno vedenje je lahko zunanje ali notranje pogojeno in se kaže s simptomi, kot so npr. agresivno vedenje, uživanje alkohola in mamil, uničevanje tuje lastnine, pobegi od doma, čustvene motnje. Otrok je lahko prepoznan kot otrok s čustvenimi in vedenjskimi motnjami le $v$ primerih, ko dosedanje delo šolske svetovalne službe in drugih strokovnih delavcev $z$ otroki, socialno skupino in družino ni vodilo do zmanjšanja opisanih težav. Kljub temu da se nekatera omenjena stanja in vzorci vedenja kažejo že zgodaj v otroštvu, se diagnoza osebnostne motnje ne postavlja, vse dokler ni zaključen otrokov osebnostni razvoj.« (ZUOPP-1, 2011).

MKB-10 (2005) v poglavju Vedenjske in čustvene motnje, ki se začnejo navadno v otroštvu in adolescenci (F9o-F98) "motnje vedenja " okarakterizira kot: »Motnje, za katere je značilen ponavljajoč se in trajen vzorec disocialnega, agresivnega ali predrznega vedenja. Takšno vedenje lahko velja za hujše kršitve starosti ustreznih družbenih pričakovanj; bile naj bi torej hujše kot običajna otroška objestnost ali adolescentna upornost in naj bi imele značaj trajnega vzorca vedenja (6 mesecev ali dalj).« (str. 379)

Bennett (v Metljak idr., 2010, str. 97) ugotavlja, da je termin »vedenjska motnja $\mathrm{v}$ "zgodovini opredeljen s celo paleto besed, ki opisujejo karakteristike asocialnega vedenja; delinkventno, neprilagojeno, deviantno, hiperaktivno, nevodljivo in agresivno vedenje.«

Myschker (2009) pri opredelitvi "vedenjske motnje« izhaja iz prilagodljivega ${ }^{8}$ (adaptive) in neprilagodljivega ${ }^{9}$ (maladaptive) vedenja. Upoštevajoč navedene značilnosti obeh oblik vedenja avtor vedenjsko motnjo ${ }^{10}$ oprede-

$7 \quad \mathrm{~V}$ nadaljevanju klasifikacija - kot primere vzorcev vedenja, na katerih temelji diagnoza - izpostavi, da le-ti »vključujejo pretirano borbenost in ustrahovanje, krutost do drugih ljudi ali živali, hudo uničevalno težnjo do lastnine, požigalništvo, krajo, nagnjenje k laganju, 'špricanje' šole in pobege od doma, nenavadno pogosto in hudo togoto ter neubogljivost" (MKB-10, 2005). Za diagnozo "motnje vedenja" po klasifikaciji zadostuje katera koli od oblik naštetega vedenja, če je izrazita.

Prilagodljivo vedenje je rezultat ustreznega zaznavanja, predelave, ovrednotenja in aktivacije. Omogoča spremembo neprimernega oz. motečega vedenja v primerno. Neprilagodljivo vedenje temelji na disfunkcionalnem sprejemanju, čustvih ter kogniciji in se manifestira v neprimernih ter socialno neustreznih oblikah premagovanja življenjskih ovir.

10 Za vedenjsko motnjo Myschker pravi, da jo je brez posebne strokovne oz. pedagoško terapevtske obravnave nemogoče zadovoljivo odpraviti. Definira jo kot fenomenološko nadrejeni pojem, kateremu se - zaradi specifičnega gledišča, aktualnost in razumevanja fenomena posameznih strok - v različnih znanstvenih disciplinah pri- 
li kot: »odstopajoče, neprilagodljivo, miljejsko povzročeno vedenje, pogojeno s časovnimi in kulturnimi pričakovanj določene družbe, ki nastane zaradi večdimenzionalnosti, pogostosti in težavnosti razvojnih, učnih ter delovnih sposobnosti, kot tudi zaradi interakcijskega dogajanja v okolju « (str. 49).

Kot Myschker definira fenomenološko nadrejeni pojem »vedenjsko motnjo«, pa Mars in Cooper (v Metljak idr., 2010, str. 95) kot krovni termin opredeljujeta »čustvene in vedenjske težave«. Le-ta, tako avtorja, »vsebuje širok spekter težav in potreb, skupaj s problemi, ki se kažejo v čustveni in vedenjski obliki, in problemi, ki vsebujejo obe dimenziji, čustveno in vedenjsko.« Metljak idr. (str. 89) na podlagi navedenega pri razumevanju čustvenih in vedenjskih težav (med drugim) izhajajo iz čustvene in vedenjske dimenzije, pri čemer je lahko izrazitejša bodisi čustvena bodisi vedenjska, "obe pa nastopata skupaj in sta v medsebojni soodvisnosti."

Kobal Tomc idr. (2011) ugotavljajo, da so čustvene in vedenjske motnje izražene v različnih stopnjah, ${ }^{\text {II }}$ katerih narava je zelo kompleksna. Pravijo, da je pri njihovi opredelitvi potrebno upoštevati medsebojno učinkovanje bioloških, psiholoških, socialnih in okoljskih dejavnikov. Čustvene in vedenjske motnje delijo na:

- $\quad$ »čustvene motnje (motnje ponotranjenja, internalizirane motnje);

- vedenjske motnje (motnje pozunanjenja, eksternalizirane motnje);

- $\quad$ vedenjske motnje, za katere je značilno intenzivno, ponavljajoče in trajno antisocialno vedenje.« (Kobal Tomc idr., 2011, str. 7)

pisujejo številne in mnoštvene pojavne oblike, ki jih zaradi navedenega razume kot podrejene (str. 49-50).

11 Podobno opredelitev je zaslediti v Kriterijih za opredelitev vrste in stopnje primanjkljajev, ovir oz. motenj otrok s posebnimi potrebami (2015), ki navajajo, da se za usmeritev otrok v kategorijo Otroci s čustvenimi in vedenjskimi motnjami upoštevajo naslednji kriteriji:

- »intenziteta čustvenih odzivov in vedenja presega stopnjo pričakovanega za razvojno obdobje ali okoliščine;

- vedenje in/ali čustvovanje je nekontrolirano ali iracionalno in se kaže vsaj šest mesecev (prim. MKB- 10, 2005); motnje se pojavljajo najmanj v dveh okoljih (npr. v šoli, doma, v vrstniški skupini, širšem okolju);

- pomembno ovirajo otrokovo učinkovitost in prilagajanje na enem ali več področjih (učni uspeh, socialni odnosi, prilagajanje šolskim pravilom, skrb zase);

- otrok nima zadosti varovalnih dejavnikov v svojem primarnem in širšem socialnem okolju (odsotnost izkušenj dobre povezanosti, doživljanje odklanjanja in zavrnitev).«(str. 32) 
Iz mnoštva predstavljenih definicij - kaj ČVT/M so in kaj niso ter kateri so tisti pogoji, ki morajo biti prisotni, da lahko govorimo o tem, da otrokovo/mladostnikovo vedenje oz. čustvovanje izstopa (prim. Kobolt, 2011) - zaključujemo, da:

- $\quad$ se pod streho definicije otrok/mladostnikov s ČVT/M skrivajo zelo različni otroci (Kosmač, 2007), ki tvorijo izrazito heterogeno skupino s specifičnimi in zelo različnimi potrebami (Kobal Tomc idr., 2011);

- $\quad$ se opredelitve ČVT/M med seboj velikokrat spodbijajo in si nasprotujejo (Kobolt, 2011; Evans, Harden in Thomas, 2004; Visser, 2003; idr.), zato igra področje, pri katerem iz opredelitev izhajamo, pomembno vlogo;

- predstavljajo poskusi definiranja ${ }^{12}$ (kot že rečeno) kompleksno problematiko (prim. Myschker, 2009; Terzi, v Opara idr., 2010; Krajnčan, 2010; idr.), ki se razprostira na kontinuumu terminološke kot tudi definicijske nedorečenosti, hkrati pa se, tako Kosmač (2007, str. 387), »hote ali nehote odražajo tudi v pojmovanju in implicitnih predstavah, ki jih do te populacije gojimo«; so ČVT/M odvisne od »časovno in kulturno pogojenih norm ter pričakovanj odklonskega, napačnega vedenja, ki nastaja zaradi organskih motenj ali neprimernega okolja, večdimenzionalnosti, pogostosti in težav v razvoju, nedoseganju učnih in delovnih zahtev, pa tudi zaradi interakcijskega dogajanja v okolju « (Krajnčan, 2006, str. 47; prim. Myschker, 2009);

- $\quad$ se čustvene in vedenjske »drugačnosti«, kot že Kobolt (2011, str. 167), »razdelijo po celotnem spektru/kontinuumu - od lažjih in redkeje izraženih do težjih/bolj nenavadnih in pogosteje izraženih« (prim. Kobal Tomc idr., 2011);

- je na ČVT/M potrebno gledati z vidika dinamike nastajanja, vzdrževanja in razvoja omenjenega fenomena $v$ specifičnem raziskovalnem področju, prav tako pa ga je treba razumeti kot večdimenzionalen, multikompleksen, interakcijski sistem psihološke,

12 O spremenljivosti definicij, tako Š. Razpotnik (2011, str. 26), govori tudi »iz različnih razlogov prisotna oteženost medsebojnih primerjav in kategorialnega aparata" (prim. Opara idr., 2010), za katero menimo, da jo je, poleg že naštetih, med drugim mogoče pripisati: 1 . neustreznemu prenosu oz. prevodu tuje terminologije v slovenski strokovni prostor ter 2. kulturni neprimerljivosti šolskega vzgojno-izobraževalnega prostora zaznavanja, diagnosticiranja ter interveniranja pri omenjeni populaciji posameznih držav. 
biološke, miljejske in socialne dimenzije razvoja posameznika, ki je s tovrstnimi težavami usodno povezan.

\section{Problematičnost opredelitev, ki izhajajo iz različnih diskurzov razumevanja}

Sprememba izrazoslovja in številčna aktualna uporaba le-tega se $\mathrm{v}$ današnjem času (bolj kot kadar koli prej) izraža v mnoštvu definicij ter poimenovanj, izhajajoč iz različnih sfer vzgojno-izobraževalnega aparata, ki laiku (tudi strokovnjaku) na omenjenem področju ne ponujajo jasnosti, temveč prej bariero nekonsistentnosti in zmede, ki posledično botruje tako zaznavanju, diagnosticiranju, nameščanju kot tudi obravnavi omenjene populacije v njim ustrezne programe pomoči.

Avtorjev, tako tujih kot domačih (npr. Kobolt, Metljak in Potočnik, 2008; Kosmač, 2007; Myschker, 2009; Razpotnik, 2011; idr.), ki izhajajoč iz različnih zornih kotov raziskovanja opozarjajo na problematičnost opredelitev ČVT/M - v polju razumevanja le-teh -, ne manjka. Nedorečenosti se kažejo tako znotraj posameznih držav, na mednarodni ravni, kot tudi med različnimi strokami (Marovič, 2017; Opara idr., 2010; Skalar, 2003). Vrsta različno utemeljenih pristopov pa aplicira na neenotnost teorij, ki jih je zaznati v raznovrstni terminologiji, s katero se populacija, katere vedenje je $\mathrm{v}$ nasprotju s prevladujočimi normami in pričakovanji socialnega okolja, opredeljuje (npr. Kenneth, Forness in Mostert, 2004; Krajnčan, 2010; Metljak idr., 2010; Vec, 2011; idr.).

Vzroke je mogoče iskati $\mathrm{v}$ različnih diskurzih razumevanja problematike, neenotnih ter kontradiktornih poimenovanjih $\mathrm{v}$ zakonodaji, neenotnosti strok (npr. pedagogike in psihiatrije), večdimenzionalnosti, v že omenjeni različnosti strokovnih paradigem idr. ter, tako Kenneth idr. (2004), v različnih socialnih kontekstih, kjer se opredelitve pojavljajo. Prav tako jasnosti ne more biti zaradi drugačnih, včasih nasprotujočih si interpretacij dotičnega (šolskega ali zavodskega) izobraževalnega aparata, iz katerega poimenovanja ČVT/M največkrat izhajajo. Če ponazorimo: ${ }^{13}$ opredelitev vedenja, npr. težavno vedenje, ima glede na okolje, iz katerega pri opredelitvi vedenja izhajamo (težavno vedenje $\mathrm{v}$ šoli ali težavno vedenje $\mathrm{v}$ zavodu), drugačno konotacijo. Vemo namreč, da je težavno vedenje, ki izhaja iz zavodskega polja, ponavadi veliko bolj »težavno« kot vedenje, ki je kot težavno opredeljeno v šoli. S težavnim vedenjem se v šoli lahko spopa-

13 Za ponazoritev smo izbrali enega izmed v slovenski literaturi uporabljajočih se terminov za opredeljevanje populacije s ČVT/M, in sicer težavno vedenje. 
demo na različne načine. $\mathrm{V}$ najslabšem primeru, seveda po vseh predhodnih intervencijah, tudi z oddajo v VZ. Če pa bi bilo vedenje, zgolj hipotetično, kot »težavno « opredeljeno v VZ (čeprav takih opredelitev vedenja $\mathrm{v}$ praksi ne podajamo), pa smo, če že drugo ne, zelo omejeni že pri samih intervencijah. Za otroka/mladostnika že nameščenega v VZ - za katerega se smatra, da posamezniku, v okviru zavodske vzgoje ter posebne zavodske obravnave, nudi vse možne oblike pomoči -, še posebej, če gre za zavod zaprtega tipa, ostaja $\mathrm{v}$ praksi bore malo alternativ. ${ }^{14}$

V literaturi, praksi ter veljavni zakonodaji za poimenovanje iste socialne pojavnosti tako danes zasledimo več med seboj ne povsem skladnih izrazov (Kosmač, 2007). Naštejmo nekatere: čustvene in vedenjske težave/ motnje, vedenjske težave/motnje, emocionalne težave/motnje, težave v socialni integraciji/adaptaciji, vedenjska problematičnost, neprilagojeno vedenje, odklonsko/deviantno vedenje, disocialnost, asocialnost, antisocialnost, delinkventnost, prestopništvo, izstopajoče vedenje, moteče vedenje, težavno vedenje, agresivno vedenje, "acting out (nekontrolirano) vedenje, vedenjska problematičnost idr. ${ }^{\text {is }}$

Sklenemo lahko, da gre pri vseh zgoraj naštetih terminih ${ }^{16}$ za $» v e d e-$ nje, ki ne ustreza pričakovanjem okolja in je zanj tako ali drugače moteče« (Bečaj, 2003, str. 13), ter za kontinuum, kjer so na eni strani prisotne značilnosti emocionalne/čustvene dimenzije, na drugi pa značilnosti dimenzije vedenj/ravnanj (Kobolt idr., 2008).

14 Posameznika, katerega vedenje bi bilo v VZ, kot že rečeno zgolj hipotetično, opredeljeno kot »težavno«, bi sicer lahko premestili v drugo vzgojno skupino, kar pa je v praksi bolj izjema kot pravilo. Premestitev predstavlja namreč, poleg že izvršene eliminacije iz primarnega okolja, še dodaten rez v njegovem življenju, z vnovično prilagoditvijo na »nove« vzgojitelje kot tudi »nove« otroke/mladostnike, s katerimi bo v nadaljevanju bival. In nenazadnje, kot ugotavljamo v praksi, tudi »težavno« vedenje s samo premestitvijo načeloma ne izzveni.

15 Kot je razvidno iz zgoraj naštetega, se termini za označevanje ČVT/M večinoma nanašajo na simptomatiko, kar pomeni, kot že Bečaj (2003, str. 13), »da ne povedo kaj dosti ali sploh ničesar o vzrokih "motnje«, o okoliščinah, v katerih je do nje prišlo, kot tudi ničesar o njeni intenzivnosti, pač pa le to, da je nekdo s svojim vedenjem prekršil določena pravila.« (prim. Kosmač, 2007). Prav tako velja opozoriti, da so ČV$\mathrm{T} / \mathrm{M}$ različno poimenovane tudi glede na to, ali se $\mathrm{z}$ določenim terminom želi poudariti etiološki, razvojni, fenomenološki, kurativni ali prognostični vidik (Škoflek, v Kosmač, 2007).

16 Čeprav je uporaba terminov mnogokrat sinonimna (prim. Bečaj, 2003; Kobolt idr., 2008; Kosmač, 2007; idr.), vsi zgoraj našteti termini niso sinonimni. Z njimi je namreč, kot že Zalokar (2013, str. 44), »mogoče izraziti različne fenomenološke in etiološke nianse asocialnega in antisocialnega vedenja." 
Če na tem mestu izpostavimo še trditev enega izmed referentov na mednarodnem kongresu za forenzično psihiatrijo, ki je ugotovil, »da uporabljamo po svetu za poimenovanje te skupine več kot 100 različnih poimenovanj« (Skalar, 2003, str. 10), je dejstvo, »da stroka tudi v mednarodnem prostoru v zvezi s kategorijo otrok s čustvenimi in vedenjskimi težavami ni oblikovala definicije, ki bi jo sprejeli kot splošno veljavno, kot smo jo npr. za slepe in slabovidne, gluhe in naglušne, za motorično in gibalno prizadete ali otroke $z$ duševnimi primanjkljaji« (str. 10-11), kot bo razvidno v nadaljevanju, še toliko bolj razumljivo.

\section{Razumevanje in opredeljevanje čustvenih in vedenjskih težav} in/ali motenj v polju vzgojnih zavodov

Strokovna literatura opredeljevanja in razumevanja ČVT/M, slovenskega kot tudi tujega raziskovalnega prostora, večinoma izhaja iz polja delovanja formalnega, predvsem osnovnošolskega izobraževanja ter v manjši meri iz polja delovanja VZ. Vendar pa omenjenih področij nikakor ne bi smeli enačiti.

Kljub temu, da zametki ČVT/M - s hkratnim sovplivanjem domačega, okoljskega ter vrstniškega miljeja - $\mathrm{v}$ večini izhajajo iz zaznavnega oz. diagnostičnega polja šolski ustanov, je obravnava populacije s ČVT/M v zavodski vzgoji veliko bolj kompleksa kot obravnava v osnovni šoli. Kot vemo, predstavljajo $\mathrm{VZ}$ zadnjega izmed vseh že predhodno izčrpanih arzenalov pomoči $\mathrm{v}$ domačem in $\mathrm{s}$ tem tudi šolskem okolju. Tako bi tudi uporaba terminov in definicij, ki jih za omenjeno populacijo uporabljamo, morala sovpadati s specifikami določenega strokovnega področja, iz katerega pri opredelitvah izhajamo, kar pa ne pomeni, da bi služila kakršni koli stigmatizaciji ${ }^{17}$ ter patologizirajočemu diskurzu, temveč le jasnosti opredelitev specifičnega razlagalnega področja. Ker v pričujočem delu izhajamo iz polja delovanja VZ, se pri interpretaciji spodaj opisanih terminov opiramo torej na zavodsko populacijo.

17 Sami menimo, da problem družbeno pogojene stigmatizacije ne leži toliko v terminologiji, ki se za poimenovanje določenega dela populacije uporablja, temveč le-ta izhaja iz domene, da je posameznik zaradi »drugačnosti«, ki mu jo družba pripisuje, v določeni instituciji nameščen (npr. psihiatrična bolnišnica, VZ, zapor idr.). Zato institucijo - bolj kot terminologijo - vidimo kot tisto, ki tako pri nameščenem posamezniku kot tudi pri večjem delu populacije vzbuja občutek, da je le-ta »drugačen, nezaželen in družbeno nesprejemljiv«. 
Z gledišča terminologije slovenskih avtorjev, ki se prvotno ukvarjajo $\mathrm{s}$ populacijo otrok in mladostnikov s ČVT/M, je v zadnjem desetletju zaznati zelo različno izrazoslovje povezano $\mathrm{z}$ omenjeno populacijo.

A. Kobolt (2010) v okviru raziskovalnega projekta $\mathrm{z}$ naslovom Problemi inkluzivne obravnave vedenjsko izstopajočih, socialno in kulturno depriviligiranih učencev in dijakov, katerega izsledki so izdani v monografiji Izstopajoče vedenje in pedagoški odzivi, uporablja izraz izstopajoče vedenje. Temeljno konceptualno usmeritev avtorjev omenjene monografije je, kot že Dekleva (2011), zaznati že v naslovu le-te, saj izbira pojme, ki ne implicirajo niti motnje niti težave, temveč poudarjajo interakcijsko naravo nastajanja težav. Izraz izstopajoče vedenje, kot nadaljuje Dekleva, "namreč sam po sebi ne implicira nikakršne motnje ali primanjkljaja«, s čimer avtorji v omenjeni monografiji »dosledno sledijo interakcijskemu pogledu na te težave in se praviloma uspešno izogibajo (predvsem) patologizirajočim diskurzom « (str. 199). Z napisanim se vsekakor strinjamo, predvsem kar se tiče patologizirajočega ter stigmatizirajočega diskurza, ki se ga $\mathrm{z}$ omenjenim poimenovanjem ogradimo. Vendar pa zgolj o izstopajočem vedenju $\mathrm{v}$ okviru populacije v VZ ne moremo govoriti. Čeprav ga A. Kobolt (2010) opredeli kot posledico nezmožnosti posameznikovega samoobvladovanja oz. kontrole nad lastnim vedenjem in kot nasledek notranje konfliktnosti, kar sicer nakazuje na tipične značilnosti večinskega dela zavodske populacije, pa eksplicitno ne nakaže, za kateri specifičen del populacije gre.$^{18}$ Zato menimo, da bi bilo izpostavljeni termin bolj smiselno uporabljati za populacijo otrok/mladostnikov, ki še bivajo v domačem okolju in obiskujejo »nezavodske« osnovne šole, kot za populacijo otrok/mladostnikov, ki so z odločbo centra za socialno delo (v nadaljevanju: CSD) že nameščeni v posamezni vzgojni ali vzgojno-izobraževalni zavod. Pri že nameščeni populaciji je namreč utopično govoriti le o izstopajočem vedenju, saj so predispozicije vedenjskih modalitet, ki so do namestitve pripeljale, največkrat geneza dolgotrajnejših ter večplastnih prepletajočih se kumuliranih ter manifestnih dejavnikov. Slednji se v nekaterih primerih že izražajo kot kompleksnej-

18 Prav tako lahko namreč navedeno nakazuje na skupine otrok/mladostnikov, ki niso uporabniki ne zavodskih kot tudi nobenih drugih storitev (npr. eksperimentiranje s kemičnimi substancami ipd.) in dokaj uspešno krmilijo potek svojega življenja v domačem okolju, pa je pri njih prav tako mogoče zaznati zgoraj navedene značilnosti, ki se občasno izražajo v obliki drugačnega, izstopajočega vedenja. Ker lahko termin izstopajoče vedenje zajema različne nianse neustreznih vedenj, ga sami razumemo kot splošen, širši termin z značilnostmi nedoločene konotacije, ki predstavlja enega izmed vidnih, zunanjih indikatorjev, ki botrujejo namestitvi v VZ. 
ša vedenjska težava, ki lahko nakazuje na simptome čustvene in vedenjske motnje ali (nemalokrat) kombinacijo obeh, kar pa seveda še ne pomeni, da je posameznik moten. Izstopajoče vedenje je, kot ugotavlja Kobolt (2010, str. 136), »lahko tudi bolj ali manj ciljno usmerjeno in motivirano. Torej načrtovano in ne tako kot $\mathrm{v}$ primerih impulzivnosti, ko posameznik nima zadostne kontrole nad svojimi vedenjskimi odzivi.« Prav impulzivnost in nezadostna kontrola posameznika nad svojimi vedenjskimi odzivi, ki se pri nekaterih posameznikih v VZ izražajo v silovitih eskalacijah vedenja, pa je pri populaciji nameščeni v VZ - predvsem, če pri razlagi izhajamo iz Redla in Winemana (1984) - velikokrat kazalec specifičnih kompleksnejših težav in slabe razvitosti njihovega »kontrolnega sistema", se pravi ega in superega. To pa prav tako kaže na neustreznost uporabe zgoraj omenjenega termina, predvsem $\mathrm{v}$ povezavi s populacijo nameščeno $\mathrm{v} \mathrm{VZ}$.

Vec (2011) v članku Moteče vedenje: ${ }^{19}$ ozadja in osnovni dejavniki, ki nanj vplivajo govori o motečem vedenju. Opredeli ga kot vedenje, pri katerem gre vedno za vedenje v socialni interakciji, v kar uvršča celoten spekter besedne in nebesedne komunikacije, ki se ne nanaša zgolj na agresivno vedenje, temveč na celoten »spekter vedenja, ki je socialno manj sprejemljivo oz. nesprejemljivo « (str. 126). Motečega vedenja ne enači z motnjami vedenja, temveč ga opredeli kot tisto vedenje, ki se lahko pojavi pred motnjami vedenja. Razliko med obema terminoma (s čimer se strinjamo) vidi v tem, »da če je vedenje nekoga moteče, še ne pomeni, da je (osebnostno) moten« (str. 128). Sami bi tu dodali še eno stališče, ki v povezavi z omenjenim terminom izhaja iz opredeljevanja populacije nameščene $\mathrm{v} V \mathrm{VZ}$ ter $\mathrm{z}$ njo povezanim vedenjem. Menimo namreč, da je verjetnost, da bi posameznik postal naslovnik zavodske vzgoje na podlagi tega, ker je njegove vedenje zgolj moteče, majhna. Zaradi motečega vedenja namreč v praksi še ne posežemo po tako skrajnem ukrepu, kot je oddaja v VZ, temveč poskušamo posamezniku, kolikor je le mogoče, z vsemi možnimi intervencijami pomagati najprej v domačem okolju. Je pa moteče vedenje - če k odpravljanju le-tega ne pristopimo dovolj hitro in učinkovito - lahko prediktor večjih vedenjskih odstopanj, ki v najslabšem primeru vodi do namestitve $\mathrm{v}$ VZ. Na podlagi navedenega menimo, da tudi dikcija moteče vedenje ni primerna za poimenovanje zavodske populacije. Ne glede na to, da je moteče

19 Avtor (2011) v povezavi z motečim vedenjem, v kontekstu čustvenih in vedenjskih težav, izpostavlja štiri osnovne dejavnike. In sicer: tiste, ki izhajajo iz skupine in skupinske dinamike; dejavnike, ki so povezani s posameznikom, njegovimi osebnostnimi, biološkimi in drugimi značilnostmi; dejavnike, ki izhajajo iz značilnosti in stilov vodenja, ter dejavnike, ki jih oblikuje institucija s svojo kuturo. 
vedenje vedno vedenje, ki je vezano na socialni kontekst, na socialno interakcijo in komunikacijo (str. 128) ter da imajo tudi ČVT/M srž predsipozicij svojega nastanka, prav tako vezane na socialni kontekst, socialno interakcijo ter komunikacijo, je patologija, ki smo ji v zadnjem času priča v VZ, veliko bolj kompleksna, da bi lahko bila poimenovana le s terminom mote$\check{c}$ e vedenje. Le-to, po našem mnenju, ne zajema celotnega kontinuuma koeksistence kompleksnosti teže težav populacije nameščene v VZ, hkrati pa je omenjeni izraz - enako kot že prej izraz izstopajoče vedenje - premalo natančno opredeljen. Ko govorimo o motečem vedenju, namreč ne "govorimo o specifičnem vzgojnem problemu (in specifičnem otroku, op. $a .^{20}$ ), temveč o mnogo širšem problemu, ki je tesno vpet $\mathrm{v}$ osnovne značilnosti sodobnih družb.« (Kobolt, 2010, str. 133). Na podlagi česar oba izraza, tako moteče vedenje kot izstopajoče vedenje, sami razumemo kot vedenje, ki bi ga v grobem lahko opredelili kot tisto vedenje, ki predstavlja vidne komponente značilnosti sodobnih družb in se lahko izraža tako v različnih življenjskih stilih posameznika kot tudi v oblikah »drugačnega« vedenja.

Oddelek za socialno pedagogiko znotraj socialnopedagoške stroke Pedagoške fakultete v Ljubljani, tako Š. Razpotnik (2011), uvaja in uporablja termin otroci in mladostniki s težavami v socialni integraciji, ki pa, kot že Krajnčan (2010), tudi nima enotne strokovne podpore. Izraz socialnointegracijske težave "poudari težavo, ki jo ima posameznik (saj ne zanika individualne ravni ali dimenzije), in vpelje socialno, družbeno, skupinsko, okoljsko raven, ki je $\mathrm{z}$ nastajanjem in vzdrževanjem tovrstnih težav usodno povezana.« (Metljak idr., 2010, str. 89). Na podlagi navedenega lah-

Na tem mestu velja - nanašajoč se na ključne dileme primerjav različnih teorij v razvojni psihologiji - izpostaviti še pomen ter interpretacijo individualnih razlik. Če pojasnimo: Thomas (v Batistič Zorec, 2006, str. 106) »navaja kot primer teorije, ki ne poudarja individualnih razlik, Gesellovo, ki govori predvsem o tipičnem otroku določene starosti«. Podobno tudi Piaget s teorijo povprečnega otroka (Batistič Zorec, 2006). Če torej v našem primeru izhajamo iz »teorij « zgoraj izpostavljenih vedenj, se uporabnost izpostavljenih terminov postavi pod vprašaj. In sicer, ali gre pri omenjenih terminih (moteče, izstopajoče vedenje) morebiti za »teoriji« vedenja, ki govorita predvsem o tipičnem otroku določene starosti in ne poudarjata individualnih razlik (OŠ, SŠ, VZ), ali pa se avtorja, sicer implicitno, prav tako ukvarjata $\mathrm{z}$ individualnimi razlikami specifičnega razlagalnega področja (npr. polje vzgojnih zavodov).

Thomas (v Batistič Zorec, 2006, str. 106) meni, »da želi večina teorij aplicirati svoj model na čim več otrok oziroma da govorijo o »otrocih v vseh prostorih in časih", kar pa za zgoraj navedena avtorja (Koboltovo in Veca) po vsej verjetnosti ne moremo trditi, saj oba, zaradi neposrednih izkušenj v polju zavodske vzgoje, pri svojih ugotovitvah (predvidevamo) najverjetneje implicitno izhajata tudi iz ugotovitev tega področja. 
ko rečemo, da omenjeni izraz z vpeljavo makrokomponent ter vzajemno povezanostjo oz. koeksistenco širšega družbenega okoljskega sistema opozori na različne indikatorje, ki znotraj skupine otrok ter mladostnikov s ČVT/M sicer že poudarijo večplasten problem, ki ga ta skupina zajema. Vendar pa smo sami mnenja, da je termin težave $v$ socialni integraciji širši, predvsem pa krovni termin, ki pomanjkljivo opredeli ter oriše specifike populacije nameščene v VZ. Podobno je s kategorijo "posebne potrebe «, ki poleg otrok/mladostnikov z disocialno simptomatiko vključuje še vrsto drugih (Bečaj, 2003). Strinjamo se z Bečajem, ki pravi, da imajo otroci z disocialno simptomatiko

"praviloma res težave $z$ vključevanjem $v$ socialno okolje, vendar pa to ni zgolj njihova posebnost (prim. Kosmač, 2007). Enake težave ima še kup drugih otrok, ki z vedenjsko problematiko nimajo nobene povezave (npr. izjemno nadarjeni). Tudi tu je torej potrebno vsakič še dodatno pojasniti, za kateri del populacije, ki ima težave $z$ $v k l j u c ̌ e v a n j e m$ v socialno okolje, gre. Oba termina sta nadredna in sama po sebi še ne označujeta kategorije otrok, o kateri govorimo. Oba sta sicer točna, za diagnostiko pa, tako kot termini, ki so vezani na simptomatiko, slabo uporabna." (str. 14)

Pomanjkljivosti, ki jih vidimo v omenjenem poimenovanju, temeljijo, poleg že navedenega, še v kompleksnosti, izraznosti ter pojavnosti težav, ki jih je pri določenem delu zavodske populacije zaznati in se kažejo v obliki Bregantove (1987a) fenomenološke klasifikacije, kar pa iz omenjenega termina zaradi nezadostne specifičnosti ni mogoče razbrati.

Poleg termina težave $v$ socialni integraciji se $\mathrm{v}$ slovenskem strokovno-raziskovalnem ter praktičnem prostoru za opredeljevanje populacije nameščene v VZ kot najpogosteje uporabljeni termini pojavljajo še: čustvene in vedenjske težave, čustvene in vedenjske motnje (prim. Kobolt idr., 2008) ali največkrat kombinacija obeh: čustvene in vedenjske težave/motnje.

21 V kategorijo OPP po ZUOPP-1 (2011) spadajo: otroci z motnjami v duševnem razvoju, gluhi in naglušni otroci, slepi in slabovidni otroci, otroci z govorno-jezikovnimi motnjami, gibalno ovirani otroci, otroci s primanjkljaji na posameznih področjih učenja, dolgotrajno bolni otroci, otroci s čustvenimi in vedenjskimi motnjami, otroci $z$ avtističnimi motnjami.

Termin »otroci s posebnimi potrebami« so v 7o. letih vpeljali Angleži (Skalar, 2003). Le-ta naj bi bil manj stigmatizirajoč, kot je npr. razvojno prizadet ali defekten, toda prav "Angleži danes odsvetujejo termin "posebne potrebe", češ da je prav tako stigmatizirajoč, kot so bili vsi drugi doslej.« (Mittler, v Skalar, 2003, str. 13). 
Poskušajmo opredeliti še razliko med razumevanjem težave in motnje. Metljak idr. (2010, str. 89) pravijo, da gre za težavo takrat, ko lahko rečemo, da "nek način čustvovanja ali vedenjskega odziva ne moti niti posameznikovega razvoja niti ni izrecno moteč za okolico«. Motnjo opredelijo kot problem posameznika in problem okolja, saj predstavlja resno oviro za njegov psihosocialni in osebnostni razvoj, hkrati pa je moteča tudi za okolje (Metljak, 2010, str. 89). Vendar pa, če pri interpretaciji zgoraj izpostavljenih terminov izhajamo iz zavodske populacije, so otroci/mladostniki v VZ (predvsem zavodih zaprtega tipa) ponavadi nameščeni ravno zato, ker je nek način čustvovanja in vedenjskega odziva motil ali posameznikov razvoj in/ali je bil moteč za okolico. Na podlagi česar bi, izhajajoč iz zgoraj navedene opredelitve obeh terminov, lahko sklepali, da pri že nameščeni populaciji ne moremo govoriti izključno o težavah, temveč tudi o motnjah, saj je ravno podana opredelitev termina motnja tisti dejavnik, ki do namestitve v praksi pripelje. Če misel razvijamo še naprej, Metljak idr. (2010, str. 89) za težave pravijo:

"Težave so lahko prehodne in z njimi se lahko posameznik kot tudi okolje precej dobro spoprime in jih obvlada. Težave so del vsakodnevnega življenja slehernega od nas. S težavo/težavami, bodisi socialnimi bodisi emocionalnimi, materialnimi, odnosnimi in drugimi, se ljudje bolje spoprimemo, če imamo podporo ožjega in širšega socialnega okolja in če najdemo dovolj primernih virov za spoprijemanje. Če okolje daje to podporo in je do potreb posameznika pozorno, se občasne težave dobro rešujejo že s pogovorom, spremembami posameznih odnosov ali elementov situacije."

Iz podane opredelitve lahko razberemo, da gre za splošen opis težav, ki ne ustreza opredelitvam težav populacije $\mathrm{v} V \mathrm{VZ}$, temveč so podane opredelitve diametralne tistim, ki do namestitve pripeljejo. Za populacijo $\mathrm{v} V Z$ je namreč značilno, da njihovih težav ne moremo opredeliti več kot predhodne, saj so se v različnih oblikah intervencij praviloma poskušale odpraviti že v posameznikovem primarnem okolju (pred namestitvijo v VZ), vključujoč različne mreže pomoči podpornih dejavnikov ožjega in širšega socialnega okolja; da se posameznik s svojimi težavami ne zna ustrezno spopadati, prav tako pa se z njimi praviloma ne zna (ali pa se ni zmožno) spopadati njegovo primarno okolje. Iz tega sledi, da jim praviloma primanjkuje podpore ožjega in širšega socialnega okolja oz. primernih ter ustreznih virov za spoprijemanje $\mathrm{z}$ različnimi vrstami težav, kar pa je med drugim tudi razlog, zaradi česar so ti posamezniki postali naslovniki zavodske vzgoje. 
Izpostaviti velja še naslednji pomislek v zvezi s poimenovanjem omenjene populacije, in sicer da je vedenje, kot vemo, interakcijsko pogojeno predvsem z okoljem posameznika. ${ }^{22}$ Vendar pa noben obstoječi termin za poimenovanje populacije $\mathrm{s}$ ČVT/M ne zajema vidika vedenja $\mathrm{v}$ taki meri, da bi bilo razvidno, da so bistvo neprimernega oz. drugačnega vedenja dolgotrajne posledice različnih kompleksnih težav $\mathrm{v}$ otrokovem/mladostnikovem okolju in ne v njem.

Če se vrnemo k terminologiji. Termin »otroci in mladostniki s čustvenimi in vedenjskimi težavami oz. motnjami«, tako Bečaj (2003), se vsaj na prvi pogled zdi bolj ustrezen. Vendar pa tudi pri tej opredelitvi obstajajo določene težave. Vemo, kot v nadaljevanju ugotavlja avtor, da obstajajo otroci/mladostniki, ki so čustveno moteni, niso pa disocialni, in taki, ki kažejo disocialno simptomatiko, niso pa čustveno moteni. Oznaka »čustvene in vedenjske motnje « torej velja la za tiste otroke/mladostnike, pri katerih najdemo oboje, kar pa izhajajoč iz ugotovitev Bečaja ${ }^{23}$ (2003) - pri čemer izhaja iz Bregantove klasifikacije - pomeni isto kot »motnje vedenja in osebnosti«, saj ta diagnoza poleg disocialne simptomatike že vključuje tudi čustvene motnje. Termin »otroci in mladostniki s čustvenimi in vedenjskimi težavami oz. motnjami«, kot pravi Bečaj, »ni tak, ker ni del sistematično kategoriziranih disocialnih motenj.«

Kontinuum razumevanja razvoja variabilnosti vedenja od težave do motnje, kot poimenovanja specifične skupine posameznikov, tako sovpada tudi z uporabo klasifikacije, iz katere pri razlagi omenjenega fenomena izhajamo. ${ }^{24}$

22 Na žalost (nemalokrat) iz tega med drugim izhaja tudi naša strokovna nezadostnost oz. (ne)pomoč, ki je posameznikom opredeljenim kot otroci/mladostniki s ČVT/M na voljo. Predvsem pri populaciji nameščeni v VZ se navedeno pokaže kot upravičeno, saj se otrokovo/mladostnikovo primarno okolje s prihodom le-tega v VZ ponavadi ne spremeni, temveč ostaja isto. Pri posamezniku je tako v zavodskem okolju sicer zaznati izboljšave njegovih neprimernih vzorcev vedenja, vendar se taisti posameznik med vikendi vrača $v$ domače (še vedno) disfunkcionalno okolje, ki v večini primerov ostaja isto, kot je bilo pred namestitvijo otroka/mladostnika v zavodsko institucijo.

23 Bistveno razliko med obema oznakama Bečaj vidi v tem, »da so »motnje vedenja in osebnosti« ena od kategorij Bregantove klasifikacije, ki pri diagnosticiranju seveda izključuje ostale kategorije in obratno: uporaba neke druge kategorije izključuje motnje vedenja in osebnosti. Informacijska vrednost take diagnostične ocene je seveda veliko večja, ker je del širše klasifikacijske sheme in s tem že sama po sebi diferencialna." (Bečaj, 2003, str. 14).

24 Vendar pa se sami na tem mestu ograjujemo od klasifikacij in se sprašujemo le o ustreznosti termina, ki bi ga bilo za poimenovanje zavodske populacije najbolj smiselno uporabljati. 
Opozoriti velja, da celotne populacije v VZ nikakor ne moremo opredeliti kot populacije $s$ »čustvenimi in vedenjskimi težavami«, prav tako pa celotne zavodske populacije ne moremo opredeliti kot populacije $s$ »čustvenimi in vedenjskimi motnjami«. Prvič zaradi tega, ker vemo, da v določenem časovnem obdobju ${ }^{25}$ (puberteti), nenadni ter predvsem neugodni življenjski situaciji, pa tudi ob stiku z določenimi osebami, lahko postane »težaven « vsak posameznik, ki na tak ali drugačen način kaže kakršno koli vedenjsko odstopanje ter ne zadovoljuje pričakovanj vedenjskih modalitet določene kulture (Bečaj, 2003; Skalar, 2003; Tomori, 1999), kar v enaki meri velja tako za nezavodsko kot tudi zavodsko populacijo. Ter drugič, ker v VZ (kot že rečeno) najdemo posameznike, ki so čustveno "moteni«, niso pa disocialni, in take, ki kažejo disocialno simptomatiko, niso pa čustveno »moteni«. Pri nekaterih je tako zaznati izrazitejše internalizirane oblike izražanja, stiske, anksioznosti in nemoči, pri drugih eksternalizirane oblike izražanja, jeze in agresije, pri tretjih kombinacijo obeh.

$\mathrm{Na}$ tem mestu velja izpostaviti še en vidik, ki se nanaša na težavnost enotnega poimenovanja populacije nameščene $\mathrm{v} \mathrm{VZ}$. Ta je, da tudi znotraj izvendružinskega institucionalnega aparata opredeljevanja, razumevanja ter interpretiranja ČVT/M - se pravi VZ, mladinskih domov ter stanovanjskih skupin - obstajajo razlike. Kljub temu, da vse zgoraj naštete institucije obravnavajo populacijo, katere značilnosti bi v grobem sicer lahko opredelili kot identične, pa $\mathrm{v}$ praksi temu ni tako. Mladinski domovi in stanovanjske skupine (že na podlagi svoje namembnosti) sprejemajo populacijo, ki se od populacije v VZ praviloma razlikuje po večji meri samostojnosti, odgovornosti ter upoštevanju pravil oz. manjši, predvsem »vedenjsko izstopajoči« problematiki, zato bi tudi tu bilo potrebno upoštevati specifike dotičnega raziskovalnega področja, iz katerih pri opredelitvah izhajamo, kar pa fenomen poimenovanja, jasnost ter ustreznost le-tega še dodatno oteži. 


\section{Sklep}

Zaključujemo, da je obravnavano področje - tudi znotraj zavodske vzgoje - zelo kompleksno, kriteriji izpostavljenih terminov nejasni in premalo opredeljeni, predvsem pa odvisni od kombinacije oz. interakcije več heterogenih dejavnikov, ki svojo pravo težo pri vsakem konkretnem otroku/ mladostniku dobijo šele $\mathrm{v}$ specifični kombinaciji, zaradi česar postane tudi uporaba terminologije precej relativna (prim. Bečaj, 2003).

Strinjamo se z Bečajem (str. 13), ki pravi, da je prehitro uvrščanje otroka/mladostnika »v kategorijo osebnostno motenega, samo zaradi prisotne simptomatike «, lahko nevarna. Zato se - kljub temu, »da se nekatera omenjena stanja in vzorci vedenja kažejo že zgodaj v otroštvu « (ZUOPP-1, 2011) - tudi sami ograjujemo od poimenovanja oz. diagnoze »osebnostne motnje«, saj se le-ta »ne postavlja, vse dokler ni zaključen otrokov osebnostni razvoj.«

Smo pa enotnega mnenja z Bečajem (2003) tudi, ko pravi, da je težava s terminologijo, ki se poskuša izogniti slabšalnemu označevanju, »v tem, da prav zaradi tega ostaja ponavadi na zelo splošni ravni, tako da nam uporabljani izrazi ne povedo, za kaj pravzaprav gre« (str. 14) oz. na katero specifično kategorijo posameznikov se določeno poimenovanje nanaša.

Na podlagi navedenega in ker je (kot že rečeno) pri zavodski populaciji zaznati kontinuum več, predvsem pa različnih nians med seboj prepletenih neustreznih vedenj, ki se lahko - odvisno od posameznika, njegovega socialnega okolja ter celotnega življenjskega mikro, mezo, eko in makro sistema - izražajo kot internalizirane oblike, eksternalizirane oblike ali kombinacija obeh, sami za poimenovanje zavodske populacije (predvsem tiste, nameščene v klasičnih oblikah zavodske vzgoje oz. zavodih »zaprtega" tipa) uporabljamo termin "čustvene in vedenjske težave in/ali motnje«, ${ }^{26}$ kar pa nikakor ne pomeni, da čustvene in vedenjske motnje enačimo $\mathrm{z}$

26 Da gre pri že nameščenem otroku/mladostniku za ČVT/M, morajo biti prisotni naslednji kriteriji (Kobolt, 2011; Bregant, 1987b):

- da gre za »neobičajno«, precej drugačno vedenje od povprečnega;

- da se čustvena in/ali vedenjska slika pojavlja intenzivno, skozi daljše časovno obdobje;

- da je vedenjski in/ali čustveni problem resen ter da obstaja nevarnost za njegov nadaljnji razvoj;

- da le-ta ogroža posameznikov razvoj in/ali je zaradi njegovega vedenja »ogrožena« okolica;

- da je z običajnimi ter razpoložljivimi intervencijami v primarnem okolju nismo uspeli ublažiti oz. odpraviti do te mere, da bi lahko bil posameznikov psihosocialni razvoj v domačem okolju optimalen. 
osebnostnimi motnjami, temveč se skušamo z omenjenim poimenovanjem le približati kompleksnim značilnostim zavodske populacije.

Zavedamo se, da tudi to poimenovanje populacije $\mathrm{v} V \mathrm{VZ}$ ni popolnoma ustrezno, da le-to še vedno izraža sled posplošitev ter da, kot že Metljak idr. (2010, str. 93), še vedno »ostaja kategorialna nalepka, ki ne odraža enkratnosti in posameznih, lahko zelo raznolikih značilnosti tako posameznika kot njegove socialne umeščenosti«. Vendar pa na podlagi dolgoletnega neposrednega dela $\mathrm{z}$ zavodsko populacijo menimo, da omenjeni izraz, s hkratnim zajetjem težave in/ali motnje, v dovolj veliki meri opozori na kompleksne značilnosti, ki jih je pri populaciji nameščeni v VZ zaznati. Z veznikom in/ali nakažemo, da lahko gre ali za težavo ali za motnjo ali pa sta prisotni obe obliki oz. komponenti vedenja.

\section{Literatura}

Batistič Zorec, M. (2006). Teorije v razvojni psihologiji. Ljubljana: Univerza v Ljubljani, Pedagoška fakulteta.

Bečaj, J. (1987). L. Bregant: Disocialnost pri otrocih in mladostnikih. Psihoterapija, 15, 9-70.

Bečaj, J. (2003). Disocialnost pri otrocih in mladostnikih. Slovenska pediatrija, 10(1), 12-27.

Bela knjiga o vzgoji in izobraževanju v Republiki Sloveniji (2011). J. Krek in M. Metljak (ur.). Ljubljana: Ministrstvo za šolstvo in šport.

Bregant, L. (1987a). Navodilo za klasifikacijo disocialnih motenj. Ptički brez gnezda, 12(25), 7-21.

Bregant, L. (1987b). Diagnostično vrednotenje in prognostična ocena disocialnih motenj. Ptički brez gnezda, 12(25), 23-27.

Byrne, Š. (2010). Sistemski pogled na vedenjske težave pri osebah z motnjami v duševnem razvoju. V V. Bužan, A. Golob, Š. Byrne in B. Hegedüš (ur.), Težave v vedenju kot izziv: Naša pot (str. 32-36). Ig: CUDV Draga.

Dekleva, B. (2011). Prikaz knjige - Alenka Kobolt (ur.): Izstopajoče vedenje in pedagoški odzivi. V O. Poljšak Škraban (ur.), Razumevanje in odzivanje na problematiko otrok s težavami v socialni integraciji (str. 197-200). Socialna pedagogika, tematska številka, 15(2).

Evans, J., Harden, A., in Thomas, J. (2004). What are effective strategies to support pupils with emotional and behavioral difficulties (EBD) in mainstream primary schools? Findings from a systematic review of research. Journal of Research in Special Education Needs. 4(1), 2-16. 
Kenneth, K., Forness, S., in Mostert, M. (2004). Defining emotional or behavioral disorders: The quest for affirmation. V P. Clough, P. Garner, J. T. Pardeck in F. Yuen (ur)., Handbook of emotional \& behavioral difficulties (str. 45-58). Thousand Oaks, CA: SAGE Publications.

Kobal Tomc, B., Centrih, M., Zalokar, L., Švab, V., Bužan, V., Klanjšček, M., in Pavlič, S. (2011). Otroci in mladostniki s hudimi motnjami vedenja Analiza stanja. Ljubljana: Inštitut Republike Slovenije za socialno varstvo.

Kobolt, A. (2010). Oblike in pogostost motečega vedenja ter razlogi, ki jih učitelji pripisujejo takemu vedenju. V A. Kobolt (ur.), Izstopajoče vedenje in pedagoški odzivi (str. 115-164). Ljubljana: Pedagoška fakulteta.

Kobolt, A. (2011). Razumevanje in odzivanje na čustvene in vedenjske težave. V O. Poljšak Škraban (ur.), Razumevanje in odzivanje na problematiko otrok s težavami v socialni integraciji (str. 153-173). Socialna pedagogika, tematska številka, 15(2).

Kobolt, A., Metljak, U., in Potočnik, Š. (2008). Zadrege z definicijami - pot $\mathrm{k}$ drugačnemu razumevanju izstopajočega vedenja. V A. Kobolt (ur.), Problemi inkluzivne obravnave vedenjsko izstopajočih, socialno in kulturno depriviligiranih učencev in dijakov (str. 48-59). Univerza v Ljubljani: Pedagoška fakulteta.

Krajnčan, M. (2006). Na pragu novega doma: Oddaja otrok v vzgojni zavod. Ljubljana: Pedagoška fakulteta.

Krajnčan, M. (2010). Otroci in mladostniki v vzgojnih zavodih, stanovanjskih skupinah in mladinskih domovih. V M. Krajnčan in P. Miklavžin (ur.), Zdravje mladostnikov s čustvenimi in vedenjskimi težavami (str. 34-55). Ljubljana: Ministrstvo za zdravje.

Krajnčan, M., in Škoflek, I. (200o). Pregled nekaterih klasifikacij motenj vedenja in osebnosti otrok in mladostnikov. Socialna pedagogika, 4(2), 167-180.

Kriteriji za opredelitev vrste in stopnje primanjkljajev, ovir oz. motenj otrok s posebnimi potrebami (2. izdaja) (2015). N. Vovk Ornik (ur.). 2. izdaja. Ljubljana: Zavod RS za šolstvo.

Kosmač, S. (2007). (Ne)ustreznost kriterijev za opredeljevanje otrok s čustveni$\mathrm{mi}$ in vedenjskimi motnjami. Socialna pedagogika, 11(3), 361-383.

Marovič, M. (2017). Participacija otroka/mladostnika v vzgojnih zavodih (Doktorska disertacija). Univerza na Primorskem, Pedagoška fakulteta, Koper.

Metljak, U., Kobolt, A., in Potočnik, Š. (2010). Narava čustvenih, vedenjskih in socialnih težav se izmika definicijam. V A. Kobolt (ur.), Izstopajoče 
vedenje in pedagoški odzivi (str. 87-113). Ljubljana: Pedagoška fakulteta Univerze v Ljubljani.

Myschker, N. (2009). Verhaltensstörungen bei Kindern und Jugendlichen: Erscheinungsformen - Ursachen - Hilfreiche Maßnahmen. Stuttgart: W. Kohlhammer Druckerei.

MKB-10 (2005). Mednarodna klasifikacija bolezni in sorodnih zdravstvenih problemov za statistične namene. Deseta revizija, 1. knjiga (2. izdaja). Ljubljana: Inštitut za varovanje zdravja Republike Slovenije.

Opara, B., Barle, A., Globačnik, B., Kobal Grum, D., Košir, S., Macedoni Lukšič, M., ... Vršnik Perše, T. (2010). Analiza vzgoje in izobraževanja otrok s posebnimi potrebami. Ljubljana: Pedagoški inštitut.

Razpotnik, Š. (2011). Družbeni kontekst kategorije »čustvene in vedenjske motnje«. V O. Poljšak Škraban (ur.), Razumevanje in odzivanje na problematiko otrok s težavami v socialni integraciji (str. 103-123). Socialna pedagogi$k a$, tematska številka, 15(2).

Redl, F., in Wineman, D. (1984). Agresiven otrok: povzetek. Ljubljana: Svetovalni center v Ljubljani, Sekcija za skupinsko delo in osebnostno rast Društva psihologov Slovenije.

Skalar, V. (2003). Socialna integracija otrok $\mathrm{z}$ vedenjskimi in čustvenimi težavami v osnovni šoli. Šolsko svetovalno delo, 3-4(8), 8-14.

Svetin Jakopič, S. (2005). Obravnava otrok in mladostnikov z vedenjskimi motnjami na centru za socialno delo: Pomoč ali prisila. Socialna pedagogika, 9(4), 391-422.

Tomori, M. (1999). Duševne motnje v razvojnem obdobju. V M. Tomori in S. Ziherl (ur.), Psihiatrija (str. 317-351). Ljubljana: Medicinska fakulteta.

Vec, T. (2011). Moteče vedenje: ozadja in osnovni dejavniki, ki nanj vplivajo. V O. Poljšak Škraban (ur.), Razumevanje in odzivanje na problematiko otrok s težavami v socialni integraciji (str. 125-152). Socialna pedagogika, tematska številka, 15(2).

Zalokar, L. (2013). Evalvacija institucionalnega obravnavanja mladinske odklonskosti - primer Vzgojnega zavoda Planina (Doktorska disertacija). Univerza v Ljubljani, Pedagoška fakulteta, Ljubljana.

Zakon o usmerjanju otrok s posebnimi potrebami (ZUOPP-1) (2011). Uradni list RS, št. 58/2011 z dne 22. 7. 2011. Pridobljeno s http://www.zrss.si/ pdf/o50911123118_zakon_o_usmerjanju_otrok_s_posebnimi_potrebami_22072011.pdf 
Zorc Maver, D. (2010). Nekateri vidiki zdravja otrok in mladostnikov. V M. Krajnčan in P. Miklavžin (ur.), Zdravje mladostnikov s čustvenimi in vedenjskimi težavami (str. 24-31). Ljubljana: Ministrstvo za zdravje. 



\title{
Vključevanje priseljenskih učencev v slovenski zakonodaji in šolski praksi
}

\author{
Andreja Sinjur \\ OŠ Dušana Bordona Semedela, Koper \\ Univerza na Primorskem, Pedagoška fakulteta
}

\section{Uvod}

Slovenija je članica Organizacije združenih narodov, UNESCA, EU in Sveta Evrope. Po 2. svetovni vojni so bili v okviru teh organizacij izdani mnogi dokumenti, ki obravnavajo področje izobraževanja zlasti $\mathrm{z}$ vidika človekovih pravic, enakih možnosti in kulturne raznolikosti. Ti dokumenti narekujejo smernice medkulturnega izobraževanja in tudi izobraževanja priseljenskih učencev. Podpisnica teh dokumentov je tudi Slovenija. Že Konvencija o otrokovih pravicah (1989) v 30. členu poudarja, da v tistih državah, $\mathrm{v}$ katerih živijo etnične, verske, jezikovne manjšine ali osebe staroselskega porekla, otroku, ki pripada taki manjšini ali ki je staroselec, ne sme biti vzeta pravica, da skupaj z drugimi člani svoje skupine uživa svojo lastno kulturo, izpoveduje in izraža svojo lastno vero in da uporablja svoj lastni jezik. V Sloveniji zagotavljanje pravic priseljenskih učencev urejajo različni zakoni in dokumenti, ki jih predstavljamo v nadaljevanju.

\section{Slovenski zakonodajni in strokovni dokumenti}

\section{Dokumenti, ki se nanašajo na pravico do vključevanja v osnovno šolo, in načelo enakih možnosti}

Pravice do vključevanja priseljenskih učencev v slovensko osnovno šolo urejajo Zakon o organizaciji in financiranju vzgoje in izobraževanja, Zakon o osnovni šoli ter Pravilnik o preverjanju in ocenjevanju znanja ter napre- 
dovanju učencev v osnovni šoli. Zakon o osnovni šoli (2007) v 10. členu otrokom, ki so tuji državljani, zagotavlja pravico do obveznega osnovnošolskega izobraževanja pod enakimi pogoji kot državljanom Republike Slovenije. Zakon o organizaciji in financiranju vzgoje in izobraževanja (2007) v 2. členu izpostavlja cilje sistema vzgoje in izobraževanja:

- zagotavljanje optimalnega razvoja posameznika ne glede na spol, socialno in kulturno poreklo, veroizpoved, rasno, etnično in narodno pripadnost, telesno in duševno zgradbo ali invalidnost;

- $\quad$ zagotavljanje enakih možnosti za vzgojo in izobraževanje otrok iz socialno manj spodbudnih okolij.

Tudi Bela knjiga (2011, str. 16-17) med splošnimi cilji vzgoje in izobraževanja poudari zagotavljanje enakih možnosti za vzgojo in izobraževanje vsakega posameznika (ne glede na spol, socialno in kulturno poreklo, veroizpoved, narodno pripadnost, svetovnonazorsko pripadnost in telesno ter duševno konstitucijo) ter nudenje ustrezne pomoči in spodbud posameznikom oz. skupinam (tj. priseljencem, ki prihajajo iz socialno in kulturno manj spodbudnega okolja, in osebam s posebnimi potrebami, ki imajo odločbo o usmeritvi).

Med načeli in cilji nadaljnjega razvoja osnovne šole Bela knjiga (2011, str. 48) poudari načelo enakih možnosti in optimalnega razvoja posameznika, in sicer zaradi individualnih razlik med učenci predlaga pestro ponudbo dejavnosti in uporabo različnih učnih pristopov $\mathrm{z}$ namenom zmanjševanja razlik med učenci, ki so povezane $\mathrm{z}$ njihovim socialno-kulturnim in jezikovnim okoljem. Torej predlaga možnost pozitivne diskriminacije za povečanje enakih izobraževalnih možnosti za otroke iz socialno in kulturno depriviligiranih okolij.

\section{Dokumenti, ki vključujejo načelo medkulturnosti}

$\mathrm{V}$ zakonodajnih dokumentih terminov, kot so večkulturnost, medkulturnost, spodbujanje medkulturnih odnosov in podobno, ne najdemo, vendar pa nekateri cilji predstavljajo izhodišče za razvoj medkulturne vzgoje in izobraževanja (Vižintin, 2013). Izhodišča za razvoj medkulturnega izobraževanja omogoča že Zakon o organizaciji in financiranju vzgoje in izobraževanja (1996) z dopolnitvami, ki v 2. členu navaja cilje sistema vzgoje in izobraževanja, med katerimi so naslednji povezani z medkulturnim izobraževanjem: 
- zagotavljanje optimalnega razvoja posameznika ne glede na spol, socialno in kulturno poreklo, veroizpoved, rasno, etnično in narodno pripadnost, telesno in duševno zgradbo ali invalidnost;

- vzgajanje za medsebojno strpnost, razvijanje zavesti o enakopravnosti spolov, spoštovanje drugačnosti in sodelovanje $z$ drugimi, spoštovanje otrokovih in človekovih pravic in temeljnih svoboščin, razvijanje enakih možnosti obeh spolov ter s tem razvijanje sposobnosti za življenje v demokratični družbi;

- razvijanje zavesti o državni pripadnosti in nacionalni identiteti in vedenja o zgodovini Slovenije in njeni kulturi;

- $\quad$ vzgajanje in izobraževanje za trajnostni razvoj in dejavno vključevanje $\mathrm{v}$ demokratično družbo, kar vključuje globlje poznavanje in odgovoren odnos do sebe, svojega zdravja, drugih ljudi, svoje in drugih kultur, naravnega in družbenega okolja, prihodnjih generacij;

- na območjih, ki so opredeljena kot narodno mešana, je omogočeno ob razvijanju slovenskega jezika tudi ohranjanje in razvijanje italijanskega in madžarskega jezika.

V 2. členu Zakona o osnovni šoli (1996) so navedeni naslednji cilji:

- $\quad$ vzgajanje za obče kulturne in civilizacijske vrednote, ki izvirajo iz evropske tradicije;

- $\quad$ vzgajanje za medsebojno strpnost, spoštovanje drugačnosti in sodelovanje $\mathrm{z}$ drugimi ter spoštovanje človekovih pravic in temeljnih svoboščin in s tem razvijanje sposobnosti za življenje v demokratični družbi;

- $\quad$ seznanjanje $\mathrm{z}$ drugimi kulturami in učenje tujih jezikov.

Ministrstvo za šolstvo in šport (danes Ministrstvo za izobraževanje, znanost in šport) je maja 2007 sprejelo Strategijo vključevanja otrok, učencev in dijakov migrantov $v$ sistem vzgoje in izobraževanja $v$ Republiki Sloveniji. V dokumentu je podana analiza stanja, našteti so problemi pri vključevanju priseljenskih učencev v slovenski vzgojno-izobraževalni sistem ter navedene zakonske podlage, ki obravnavajo njihovo izobraževanje. $\mathrm{V}$ dokumentu so poudarjena načela vključevanja in predlagani ukrepi, ki bi pripomogli k izboljšanju razmer na omenjenem področju. S predlaganimi ukrepi avtorji pokažejo na potrebo po oblikovanju ustreznih zakonskih aktov, ki naj jih pripravijo pristojna ministrstva s pomočjo institucij, kot sta Center za slovenščino kot drugi/tuji jezik in Zavod Republike Slovenije za 
šolstvo. V Strategiji (2007, str. 12) so opredeljeni tudi cilji vključevanja priseljenskih učencev:

- na sistemski ravni zagotavljanje pogojev, možnosti in priložnosti, ki omogočajo doseganje ciljev oz. standardov znanja, ki so opredeljeni v učnih načrtih;

- $\quad$ uspešna vključenost otrok migrantov v šolsko, socialno in pozneje poklicno okolje;

- razvijanje zmožnosti za predstavljanje lastne kulture, zaznavanje, razumevanje in sprejemanje drugačnosti za premagovanje predsodkov do drugih kultur, primerjanje kultur, vzgajanje k strpnosti, ohranjanje oz. nadgrajevanje lastne identitete in kulture;

- $\quad$ znanje slovenščine v taki meri, da zagotavlja uspešno vključevanje v sistem vzgoje in izobraževanja, to pa pomeni:

- razvijanje jezikovne zmožnosti (otroci usvojijo oz. se naučijo zadostnega nabora besedišča, slovničnih in sporazumevalnih vzorcev za uspešno sporazumevanje v šolskem okolju: sporazumevanje z učitelji, sporazumevanje z vrstniki, dejavno sodelovanje pri pouku);

- razvijanje socialne zmožnosti (zmožnost izražanja mnenja, želja, namere oz. ustreznega reagiranja na želje drugih. Otroci imajo to zmožnost že razvito, vendar so jo razvili v lastnem okolju in jo znajo realizirati le v svojem jeziku ter na način, ki ustreza ustaljenim vzorcem v njihovem sociokulturnem okolju. Učenje jezika je tudi socializacijski proces, prilagajanje novim življenjskim okoliščinam, govornim položajem);

- razvijanje spoznavne zmožnosti (širjenje otrokovega pojmovnega sveta).

M. Vižintin (2013, str. 191) ugotavlja, da je Strategija (2007) v slovenski prostor prinesla kritičen, realen in do leta 2007 najbolj natančen pogled na pomanjkljivo slovensko zakonodajo in neurejene razmere pri vključevanju otrok priseljencev ter tudi predloge za spremembe.

Zavod Republike Slovenije za šolstvo je na podlagi Strategije leta 2009 izdal dokument Smernice za izobraževanje otrok tujcev v vrtcih in šolah (2009), leta 2012 pa je omenjeni dokument dopolnil in izboljšal ter izdal Smernice za vključevanje otrok priseljencev v vrtce in šole (2012). Smernice (2012) opredeljujejo ukrepe, strategije, prilagoditve za delo in načine sodelovanja ter vključevanja otrok in njihovih staršev na področju vzgoje 
in izobraževanja. S konkretnimi predlogi za uspešno vključevanje priseljenskih učencev podpirajo razvoj medkulturne vzgoje in izobraževanja. Namenjene so tako za delo s priseljenskimi učenci kot tudi za vso populacijo učencev. Upoštevano je načelo avtonomije, zato vsaka vzgojno-izobraževalna ustanova sama pripravi izvedbeni načrt aktivnosti, ki vključuje in upošteva značilnosti in posebnosti učenca ter $\mathrm{v}$ skladu $\mathrm{z}$ veljavnimi predpisi in pričujočimi smernicami poišče najustreznejše rešitve konkretnih problemov.

Bela knjiga (2011, str. 45) slovenske družbe sicer še ne opredeljuje kot večkulturne, vendar pa poudarja vzgojo za medkulturnost, kar razberemo iz naslednjega: »Z veliko verjetnostjo je mogoče predvidevati, da bo Slovenija postajala večkulturna država, ki bo zaznamovana $\mathrm{z}$ intenzivnejšimi medkulturnimi vplivi, zato je treba že danes misliti na prihodnje razmere in pripravljati sedanje generacije na življenje v spremenjenih razmerah. Predvidevamo lahko, da bo naša družba vse bolj odprta tudi za priseljevanje ljudi iz drugih kulturnih okolij, zato je pomembno vzgajati in izobraževati za medsebojno spoštovanje in dialog.« Hkrati Bela knjiga (2011, str. 116-117) opredeli šolo kot prostor, v katerem se srečujejo posamezniki različnih narodnosti, socialno-kulturnih okolij, etičnih skupin, veroizpovedi, svetovnonazorskih prepričanj in podobno. Berdajs (2016) pravi, da je treba vzgojno-izobraževalno delo organizirati tako, da bo spoštovalo človekove pravice in temeljne svoboščine ter omogočalo optimalen razvoj vsem otrokom ne glede na izobrazbo njihovih staršev, njihov socialno-ekonomski položaj, narodno pripadnost, spol in podobno. Bela knjiga (2011, str. 116-117) pravi, da se mora šola pri vzgoji osredotočiti zlasti na razvijanje medsebojne strpnosti, solidarnosti, odgovornosti, spoštovanja drugačnosti, medgeneracijskega sožitja in s tem na razvijanje sposobnosti za življenje $\mathrm{v}$ demokratični družbi. Med načeli izpostavi načelo oblikovanja in širjenja nacionalne kulture in spodbujanja medkulturnosti, ki vključuje poznavanje in oblikovanje kulture, oblikovanje zavesti o pomenu kulture in spodbujanje medkulturnosti. Poleg razvijanja in ohranjanja lastne kulturne tradicije šola spodbuja medkulturnost, seznanja učence $\mathrm{z}$ obče kulturnimi in $\mathrm{s}$ civilizacijskimi vrednotami, $\mathrm{z}$ drugimi kulturami in prispeva $\mathrm{k}$ spoštovanju pluralizma kultur. Posebno pozornost je treba nameniti tudi kulturam učencev priseljencev. Med cilji osnovne šole pa Bela knjiga (2011, str. 118) navede, da razvija sposobnosti za razumevanje različnosti:

spoštovanje človekovih pravic in temeljnih svoboščin ter vzgajanje za udejanjanje dolžnosti posameznika, ki izhajajo iz teh pravic; 
- $\quad$ vzgajanje za medsebojno strpnost, spoštovanje drugačnosti in sodelovanje $z$ drugimi;

- poznavanje, razvijanje in ohranjanje lastne kulture, razvijanje narodne identitete in spoznavanje kultur drugih narodov;

- $\quad$ vzgajanje za obče kulturne in civilizacijske vrednote, ki izvirajo iz evropske tradicije.

\section{Dokumenti, ki obravnavajo učenje slovenščine kot jezika okolja}

Vloga slovenščine kot enega od ključnih pogojev za uspešno vključevanje priseljenskih učencev v slovenske šole je bila $\mathrm{v}$ šolskih dokumentih prvič jasneje izpostavljena v Strategiji (2007). V tem dokumentu je tudi jasno izraženo, da gre pri priseljenskih učencih večinoma za govorce slovenščine kot drugega jezika, ki potrebujejo drugačen način poučevanja slovenščine. Zakon o osnovni šoli (8. člen) že od leta 1996 predvideva možnost, da se za otroke slovenskih državljanov, ki prebivajo v Republiki Sloveniji in katerih materni jezik ni slovenski jezik, lahko dodatno organizira pouk slovenskega jezika. Torej za priseljenske učence prve generacije, ki so se vključili v osnovno šolo, ni bil predviden dodatni pouk slovenščine. To je bilo omogočeno šele novembra 2007, ko imajo priseljenski otroci, pri katerih materni jezik ni slovenščina in nimajo državljanstva RS, po priselitvi v Slovenijo pravico do tečaja slovenščine (Zakon o osnovni šoli, 2007, 10. člen).

Tudi Smernice (2012) izpostavljajo učenje slovenščine kot ključni element za zagotavljanje možnosti komunikacije. Šola naj spodbuja učenje jezika učnega okolja, to je slovenščine, in maternega jezika posameznega otroka. Za priseljenske otroke s pomanjkljivim znanjem slovenščine mora šola ob vstopu v skladu z možnostmi organizirati učenje in izpopolnjevanje slovenščine, pri čemer se stopnja in obseg učenja prilagodita ravni ugotovljenih individualnih jezikovnih zmožnosti in potrebam. Po potrebi se tudi v nadaljnjih letih šolanja organizira pomoč pri učenju slovenščine v okviru nadaljevalnih tečajev, dopolnilnega pouka, obveznih izbirnih predmetov. Smernice (2012) opozarjajo, da mora šola zagotoviti, da priseljenske učence poučujejo učitelji, ki so usposobljeni za poučevanje slovenščine kot drugega jezika in imajo razvite medkulturne kompetence. Zagotavljanje učenja slovenščine kot drugega jezika je izpostavljeno tudi v Resoluciji o nacionalnem programu za jezikovno politiko 2014-2018 (2013). Med ukrepi so navedeni: prenova normativov in standardov $\mathrm{z}$ vidika uvedbe uvajalnih intenzivnih tečajev slovenščine za priseljenske učence; oblikovanje učnega načrta za slovenščino kot drugi jezik v osnovni šoli na podlagi definiranega obsega 
in oblike učenja slovenščine kot drugega/tujega jezika; izdelava ustreznih e-gradiv (vključno s priročniki, kot so slovnica in slovarji), namenjenih za samostojno učenje in kombinirano učenje za najrazličnejše ciljne publike.

\section{Zakonske podlage, ki urejajo področje učenja maternega jezika priseljenskih učencev}

Evropski parlament (2009) poziva vlade držav članic, naj otrokom zakonitih priseljencev zagotovijo brezplačno izobraževanje, hkrati z učenjem uradnega jezika države gostiteljice in maternih jezikov priseljenskih učencev. Slovenija mora kot članica EU na podlagi načela enakih pravic učencem ponuditi učenje maternega jezika. V državah članicah EU obstajata dva glavna pristopa $\mathrm{k}$ učenju maternega jezika priseljenskih učencev: Direktiva Sveta Evropske skupnosti o izobraževanju otrok delavcev migrantov iz leta 1977 in dvostranski sporazumi s tretjimi državami, ki niso članice EU (Sinjur, 2010). Ohranjanje maternega jezika priseljenskih učencev je tudi ustavna pravica, saj Ustava Republike Slovenije v 61. členu določa, da ima vsakdo pravico, da svobodno izraža pripadnost svojemu narodu ali narodni skupnosti, da goji in izraža svojo kulturo in uporablja svoj jezik in pisavo (Ustava, 2006). Zakonodaja že od leta 1996 omogoča možnost učenja maternega jezika, saj predvideva, da se za otroke slovenskih državljanov, ki prebivajo v Republiki Sloveniji in katerih materni jezik ni slovenski jezik, $\mathrm{v}$ skladu $\mathrm{z}$ mednarodnimi pogodbami organizira pouk njihovega maternega jezika in kulture (Zakon o osnovni šoli, 8. člen). Prav tako se v skladu $\mathrm{z}$ mednarodnimi pogodbami organizira pouk maternega jezika in kulture za otroke, ki so tuji državljani oz. osebe brez državljanstva in prebivajo v Republiki Sloveniji (Zakon o osnovni šoli, 10. člen). Zakon o organizaciji in financiranju vzgoje in izobraževanja v 81. členu določa, da država zagotavlja sredstva za poučevanje maternega jezika za tujce, vključene v redno osnovnošolsko izobraževanje. Leta 2011 Zakon o osnovni šoli v 8. členu odpravlja razlikovanje med otroki priseljenci $z$ državljanstvom ali brez njega in predvideva pouk njihovega maternega jezika in kulture s sodelovanjem $\mathrm{z}$ državami izvora. Tudi Bela knjiga (2011) poudarja, da morajo imeti materni jeziki učencev, katerih materinščina ni slovenščina, posebno mesto. Predlaga, da bi imeli priseljenci v osnovni šoli možnost učenja svojega prvega jezika/ materinščine in kulture, saj je dobro razvita jezikovna zmožnost v prvem jeziku eden od temeljnih pogojev za razvoj jezikovne zmožnosti v vseh drugih jezikih. Zato naj šola (lahko tudi v sodelovanju z drugimi šolami) oblikuje skupine za učenje maternega jezika in kulture za učence, katerih ma- 
terni jezik ni slovenščina, v obsegu ene ure na teden za skupino učencev. Prav tako je izhodišče jezikovne politike v Sloveniji, da imajo vsi govorci, katerih prvi jezik ni slovenščina, v skladu s človekovimi pravicami in načeli EU pravico ohranjati in obnavljati lastni jezik in kulturo (Resolucija o nacionalnem programu za jezikovno politiko 2014-2018, 2013).

\section{Zakonodaja o preverjanju in ocenjevanju znanja ter napredovanju priseljenskih učencev}

Pravilnik o preverjanju in ocenjevanju znanja ter napredovanju učencev $v$ osnovni šoli (2013, 15. člen) omogoča od leta 2008 prilagajanje ocenjevanja med šolskim letom: "Za učenca priseljenca iz druge države se lahko v dogovoru s starši med šolskim letom prilagodijo načini in roki za ocenjevanje znanja, število ocen ter drugo. Znanje učenca priseljenca iz druge države se lahko ocenjuje glede na njegov napredek pri doseganju ciljev oz. standardov znanja, opredeljenih v učnih načrtih. O prilagoditvah ocenjevanja med šolskim letom iz tega člena odloči učiteljski zbor. Prilagoditve ocenjevanja med šolskim letom se učencu priseljencu iz druge države upoštevajo največ dve šolski leti po vključitvi v osnovno šolo v Republiki Sloveniji.« Glede nacionalnega preverjanja znanja pa zakonodaja omogoča, da »učenci priseljenci iz drugih držav, katerih materni jezik ni slovenski in se prvič vključijo v osnovno šolo v Republiki Sloveniji v 6. in 9. razredu, opravljajo v tem šolskem letu nacionalno preverjanje znanja prostovoljno« (Zakon o osnovni šoli, 64. člen).

O napredovanju pa v Zakonu o osnovni šoli v 69. členu piše, da so lahko učenci priseljencev iz drugih držav ob koncu pouka v šolskem letu, v katerem so prvič vključeni v osnovno šolo v Republiki Sloveniji, neocenjeni iz posameznih predmetov in napredujejo v naslednji razred. O napredovanju odloči na predlog razrednika učiteljski zbor.

\section{Podporne oblike pomoči priseljenskim učencem v zakonodaji}

\section{Učenje slovenščine kot drugega jezika}

Za priseljenske učence je slovenščina drugi jezik oz. jezik novega okolja, ki se ga morajo naučiti, če se želijo vključiti v to okolje. Hkrati je zanje tudi učni jezik, saj poučevanje poteka v slovenščini. Prav tako pa je glede na predmetnik devetletne osnovne šole slovenščina zanje tudi učni predmet. Z vključitvijo v osnovno šolo so priseljenski učenci postavljeni pred dve nalogi hkrati: učenje nove snovi v jeziku, ki ga ne obvladajo, in (posredno) 
učenje jezika. To ni enako kot učenje jezika. Učenje jezika je osredinjeno na pridobivanje jezikovnih sposobnosti in naj bi potekalo pred vstopom $\mathrm{v}$ šolo, kadar je to možno. Učenje (razumevanje in pomnjenje) nove snovi in seznanjanje z novim jezikom sta za učenca priseljenca zelo težavni nalogi (Knaflič, 2010).

Krek in Vogrinc (2005) ugotavljata, da je pogoj uspešne vključitve učencev iz jezikovno, kulturno in socialno deprivilegiranih družin $\mathrm{v}$ vzgojno-izobraževalni sistem ustrezno začetno opismenjevanje teh učencev. Slabše obvladovanje ali neobvladovanje slovenskega sporazumevalnega jezika vodi do neučinkovitega dela $\mathrm{v}$ šoli, saj učenec ni zmožen slediti pouku zaradi jezikovne pregrade. Problem priseljenski učencev je nezadostno obvladanje slovenskega jezika ob vključevanju v šolski sistem oz. obremenjenost $\mathrm{z}$ vzporednim usvajanjem slovenščine in obvladovanjem učne snovi (Krek in Vogrinc, 2005). Obvladanje učnega jezika je za potek šolanja nujno, saj učenci, ki ne obvladajo učnega jezika, v učnem procesu ne morejo razviti vseh svojih sposobnosti (Knaflič, 2010). Knez (2012) poudari razliko med vsebinami in pristopi pri poučevanju in preverjanju znanja pri prvem ali drugem jeziku. Učenci rojeni govorci svoje dobro znanje slovenščine v šoli nadgrajujejo, učenci priseljenci pa se (običajno) s slovenščino srečujejo prvič in se jo morajo naučiti »od začetka«. Zato je pri načrtovanju začetnega pouka slovenščine za učence priseljence smiselno $\mathrm{v}$ ospredje postaviti tiste vsebine, ki so potrebne za sporazumevanje v vsakdanji komunikaciji in pri spremljanju drugih predmetov, pozneje pa dodati metajezikovna in literarna znanja.

Od leta 2007 Zakon o osnovni šoli (10. člen) predvideva organizacijo tečaja slovenščine za otroke, ki prebivajo v Sloveniji, a so tuji državljani ali osebe brez državljanstva in potrebujejo pomoč pri učenju slovenščine. Šole zaprosijo za finančno pomoč Ministrstvo za izobraževanje, znanost in šport (81. člen Zakona o organizaciji in financiranju vzgoje in izobraževanja), ki jim praviloma financira do 35 ur dodatnega pouka slovenščine na leto za posameznega otroka. V zakonodaji ni določeno, kako bo potekalo učenje slovenščine, ampak je izvedba prepuščena šolam. Poteka zelo različno: kot dodatne ure med/pred poukom ali po njem, v oddelkih podaljšanega bivanja, kot individualna strokovna pomoč, interesna dejavnost ali tečaj (Knez, 2009). Tudi profil učitelja, ki poučuje slovenščino kot drugi jezik, ni določen, torej učitelji, ki poučujejo slovenščino kot drugi jezik, največkrat niso usposobljeni za poučevanje jezika oseb, ki jim slovenščina ni materni jezik. To pomeni, da so priseljenski učenci po 35-urnem te- 
čaju večinoma deležni poučevanja slovenskega jezika kot učenci, ki jim je slovenščina materinščina. Prav tako ustrezne podpore pri svojem pedagoškem delu niso deležni slovenski učitelji, saj so večinoma tako rekoč postavljeni pred dejstvo, da je v razredu učenec, ki slovenskega jezika ne razume (Lesar, Čančar in Jug Došler, 2012). Vižintin (2014, str. 78) poudarja, da je pouk slovenščine kot drugega jezika temeljna oblika podpore za uspešno vključevanje otrok priseljencev v novo okolje, zato je pomembno, da je organiziran strokovno, sistematično in prilagojeno individualnim potrebam. Vendar za poučevanje slovenščine kot drugega jezika ni ustreznega učnega načrta. Upoštevajoč dejstvo, da je slovenščina za nekatere učence materni, za druge pa drugi jezik, K. Skubic Ermenc (2010a) predlaga pripravo učnega načrta za slovenščino kot drugega jezika (kot pri učnih načrtih za madžarsko in italijansko manjšino), s čimer se strinja tudi Bela knjiga (2011). Takšen učni načrt bi bil lahko bodisi osnova za dopolnilni pouk slovenščine bodisi za oblikovanje novega učnega predmeta - slovenščina kot drugi jezik. Vendar pa omenjena avtorica pri tem opozarja, da oblikovanje novega predmeta prinaša tveganje, saj lahko pripomore $\mathrm{k}$ ločevanju učencev. Za čim bolj kakovosten pouk slovenščine kot drugega jezika M. Vižintin (2014) svetuje usposabljanje za poučevanje slovenščine kot drugega jezika, študij strokovne literature s tega področja ter izmenjavo izkušenj z drugimi učitelji slovenščine kot drugega jezika. Predlaga fleksibilno obliko izvajanja pouka slovenščine kot drugega jezika: poleg uvajalnice naj se pouk slovenščine kot drugega jezika izvaja med poukom, na začetku intenzivneje, postopoma pa naj bo otrok vedno več vključen v redni vzgojno-izobraževalni proces.

Tudi Bela knjiga (2011) ugotavlja sistemsko neurejenost. Šole se morajo tako znajti po svoje in izkušnje kažejo, da je njihovo uresničevanje odvisno zlasti od ozaveščenosti in angažiranosti posameznih učiteljev in ravnateljev. Zato Bela knjiga poudari, da je treba nujno ponuditi ustrezno sistemsko rešitev in $\mathrm{v}$ njej natančno opredeliti: obseg dodatnega pouka, njegove obliko in vsebine ter kdo so lahko izvajalci dodatnega pouka in kakšna naj bo njihova strokovna usposobljenost. Predlaga tako obliko učenja slovenščine, ki bo učencem omogočala učinkovito jezikovno napredovanje, hkrati pa jih ne bo izključevala ali marginalizirala. Predlagana je obvezna strnjena začetna oblika jezikovnega tečaja (do 240 ur), ki jo je možno zagotoviti z regijskim medšolskim sodelovanjem. Po potrebi se nadaljuje dodatno učenje slovenščine $\mathrm{v}$ okviru diferenciacije in individualizacije rednega 
pouka, kombinirano s pomočjo učencev s podobno izkušnjo (oblike tutorstva). Posebej je poudarjeno tudi vzpodbujanje staršev $k$ učenju slovenščine.

Stanje se sicer izboljšuje, saj je $\mathrm{v}$ zadnjih letih izšlo nekaj učnega gradiva, ki je učiteljem $\mathrm{v}$ pomoč pri učenju slovenščine kot drugega jezika, Center za slovenščino kot drugi/tuji jezik pa izvaja usposabljanja za učenje slovenščine kot drugega jezika za učitelje.

\section{Učenje maternega jezika}

Formalno-pravno imajo priseljenski učenci (oz. vsi, katerih materni jezik ni slovenščina) v Sloveniji možnost učenja maternega jezika. Vendar pa uresničevanje teh pravic ni sistemsko urejeno. V praksi se izvaja učenje maternih jezikov učencev priseljencev v obliki dopolnilnega pouka ali izbirnega predmeta. Po sklepu ministra o sofinanciranju dopolnilnega pouka maternih jezikov in kultur za otroke priseljencev v šolskem letu 2014/15 dopolnilni pouk maternega jezika izvaja osnovna šola, sredstva za izvajanje pa zagotavljata Ministrstvo za izobraževanje, znanost in šport ter države, katerih jezik se poučuje, ali starši učencev, ki bodo pouk obiskovali, ali druge osebe. Države, katerih jezik se poučuje, ali starši ali druge osebe zagotavljajo plačilo učitelja ter njegove potne stroške, medtem ko Ministrstvo za izobraževanje, znanost in šport zagotavlja letni pavšalni znesek na učenca ali dijaka, ki obiskuje dopolnilni pouk, ki zadostuje za plačilo uporabe prostorov (najmanj) 6o ur pouka, nabavo učil in učnih pripomočkov za učenca ter materialne stroške za izvedbo programa (fotokopiranje, telefon, drobni potrošni material in drugo).

Druga možnost učenja maternega jezika je v obliki izbirnega predmeta, pri katerem pa ti jeziki niso opredeljeni kot prvi jeziki, temveč se obravnavajo kot tuji. Kljub dobro urejeni teoretični podlagi učenja maternega jezika učencev priseljencev pa je v praksi le nekaj šol, ki ponujajo in izvajajo učenje maternega jezika. Priseljenski učenci iz Makedonije se lahko učijo materni jezik od leta 1993, v zadnjih letih pa tudi priseljenci iz drugih držav. Za učence priseljence iz držav EU Slovenija trenutno na podlagi Direktive Sveta Evropske skupnosti (1977) sofinancira pouk nemščine in finščine. Na podlagi bilateralnih sporazumov pa Ministrstvo za izobraževanje, znanost in šport sofinancira dopolnilno učenje albanščine, ruščine in makedonščine. Dopolnilno učenje hrvaščine financira država Hrvaška sama (Sinjur, 2010). V manjšem številu šol pa se izvaja učenje maternih jezikov kot izbirnega jezika (Komac, Medvešek in Roter, 2007). 
Smernice (2012) spodbujajo branje knjig in drugih publikacij v maternem jeziku in organiziranje bralne značke $v$ maternih jezikih. O pomenu maternega jezika bi bilo treba izobraziti tudi pedagoške delavce, saj raziskava (Krek in Vogrinc, 2011) ugotavlja, da le dobra tretjina osnovnošolskih učiteljev ( $38 \%)$ meni, da bi šola morala poskrbeti, da bi se učenci, katerih materni jezik ni slovenščina, učili tudi svoje materne jezike.

\section{Prilagoditve metod in oblik dela}

V skupino učencev $\mathrm{z}$ učnimi težavami so vključeni tudi učenci, katerih težave pri učenju so posledica kulturne in ekonomske prikrajšanosti ter težave, povezane $z$ večjezičnostjo in večkulturnostjo (Magajna idr., 2008), torej $\mathrm{v}$ to skupino sodijo tudi priseljenski učenci.

Zakon o osnovni šoli $\mathrm{v}$ 12. členu navaja, da so osnovne šole učencem $\mathrm{z}$ učnimi težavami dolžne prilagajati metode in oblike dela ter zagotavljati dopolnilni pouk in druge oblike individualne in skupinske pomoči. Država financira izvedbo dopolnilnega pouka (1 uro dopolnilnega in dodatnega pouka na oddelek) in pol ure drugih oblik individualne in skupinske pomoči na oddelek (Zakon o financiranju, 81. člen).

Učenci priseljenci so tako upravičeni do prilagajanja metod in oblik dela med poukom, obiskovanja dopolnilnega oz. dodatnega pouka ter obiskovanja individualne oz. skupinske pomoči. Če učenec kljub vsem učiteljevim prilagoditvam pri rednem in dopolnilnem pouku ter $\mathrm{v}$ okviru podaljšanega bivanja ne napreduje, potem se na učiteljevo pobudo ali pobudo staršev vključi še svetovalni delavec. Naslednja stopnja pomoči pa je pomoč $\mathrm{v}$ obliki individualne oz. skupinske pomoči.

\section{Prilagoditve preverjanja, ocenjevanja, napredovanja in opravljanja NPZ za priseljenske učence}

Od leta 2008 imajo priseljenski učenci možnost do dvoletnega prilagojenega preverjanja in ocenjevanja znanja ter možnost napredovanja $\mathrm{v}$ naslednji razred kljub neocenjenosti. Priseljenski učenci v prvem letu vključitve $\mathrm{v}$ osnovno šolo nacionalno preverjanje znanja opravljajo prostovoljno. Odgovornost za prilagojeno preverjanje in ocenjevanje znanja prenaša zakonodaja na celoten učiteljski zbor, in to $\mathrm{v}$ dogovoru s starši. Pravne podlage za izvajanje prilagojenega ocenjevanja so zelo splošne in ohlapne, vsaka šola pa se po svoje spopada $\mathrm{z}$ ocenjevanjem priseljenskih učencev. Prilagoditve se izvajajo na posameznih šolah različno (Vižintin, 2013): 
- $\quad$ učenci priseljenci prvo leto po vpisu niso ocenjeni ali pa so ocenjeni le pri posameznih učnih predmetih in kljub temu napredujejo v višji razred;

- učitelji preverjajo in ocenjujejo znanje na različne načine: ustno, individualno, s podaljšanim časom pisanja, $\mathrm{z}$ dodatno razlago, možnostjo uporabe slovarja ali spletnega prevajalnika, uporabo slikovnega gradiva;

- $\quad$ pri preverjanju in ocenjevanju priseljenski učenci uporabljajo svoj materni jezik ali skupni vmesni jezik, ki ga razume tako učenec priseljenec kot učitelj;

- $\quad$ učitelji pripravljajo za priseljenske učence posebne učne liste, $s$ pomočjo katerih dosegajo standarde znanja skladno $\mathrm{z}$ individualnim napredkom posameznega učenca priseljenca (ki se spremlja v individualnem programu).

Ohlapnost pravil je lahko priložnost za fleksibilno prilagajanje individualnim situacijam. Učitelji lahko tako po svoji presoji nekatere standarde znanja ocenijo v tekočem šolskem letu, nekatere pa šele v naslednjem.

\section{Individualni program}

Pomoč otrokom, ki imajo učne težave, in v to skupino so vključeni tudi priseljenski učenci ali »drugojezični oz. socialno-kulturno drugačni učenci«, je lahko nudena tudi s pomočjo koncepta individualnega programa (Magajna idr., 2008, str. 68).

Smernice (2007) predlagajo, naj šola glede na ugotovljeno predznanje priseljenskega učenca izdela individualni načrt aktivnosti, ki vsebuje načrt notranje individualizacije in diferenciacije, program dopolnilnega in dodatnega pouka ter druge ukrepe, tako da upošteva učne in druge potrebe ter specifiko učencev, ki pripadajo drugim kulturam. Individualni načrt aktivnosti pa naj vključuje tudi načrt spremljanja doseganja vzgojno-izobraževalnih ciljev ter vloge in odgovornosti strokovnih delavcev, učenca in staršev. Ker prihajajo učenci priseljenci z različnimi predznanji, se zdi smiselno, da se za vsakega učenca pripravi individualni program, ki vključuje informacije o učenčevem predhodnem šolanju, predznanju, izpostavijo se njegova močna in šibka področja, vanj učitelji posameznih predmetnih področij zapišejo cilje, prilagoditve pri učnih predmetih ter jih tudi spremljajo in evalvirajo. Načrtovane so vsebinske prilagoditve in tudi prilagoditve ocenjevanja. 
K. Skubic Ermenc (2010b) je do tega, da se z učenci priseljenci postopa po nekih posebnih postopkih in se zanje pripravljajo posebni programi, kritična. Predlaga pripravo individualnih programov za vse učence, saj bi tako individualizirali in diferencirali pouk brez stigmatizacije.

\section{Podporne oblike pomoči priseljenskim učencem v šolski praksi}

V zadnjem desetletju so se v Sloveniji izvajali številni projekti, dejavnosti, raziskave in usposabljanja za spodbujanje medkulturnosti, učenje slovenščine kot drugega jezika, aktivnega državljanstva, medkulturnega dialoga, razvoj medkulturne zmožnosti vseh prebivalcev, saj so praksa in raziskave pokazale, da za uspešno vključitev priseljenskega učenca ni dovolj le njegova vključitev v razred sovrstnikov, ampak da so za uspešno vključevanje priseljenskih učencev odgovorne tako šole $\mathrm{z}$ učitelji kot širše družbeno okolje. Nekatere slovenske osnovne šole so v sodelovanju z zunanjimi institucijami v okviru projektov že oblikovale podporne mehanizme za lažje vključevanje učencev priseljencev v šolo, ki lahko predstavljajo dobro izhodišče za uspešno vključevanje priseljenskih učencev v osnovne šole (Vižintin, 2013; Knez, 2012). Cilj teh programov je omilitev »kulturnega šoka« in ublažitev njihovih socialnih stisk (osamljenost, odrinjenost, zaznamovanost), ki jih doživijo priseljenski učenci ob selitvi v novo okolje in vstopu v šolo. Nekatere podporne oblike pomoči so predstavljene v nadaljevanju.

\section{Intenzivni tečaj slovenščine pred vključitvijo v pouk}

$\mathrm{Na}$ Centru za slovenščino kot drugi/tuji jezik so izvedli pet pilotnih tečajev slovenščine, $v$ katere so se vključili učenci priseljenci ob začetku njihovega šolanja v Sloveniji in njihovi starši. V tečaj so vključili tudi učence, ki so slovenske šole obiskovali že preteklo leto, vendar $\mathrm{v}$ znanju slovenščine niso napredovali. Tečaji so bili zelo intenzivni (pouk je potekal štirinajst dni vsak dan po šest šolskih ur, skupaj torej 60 ur) in so, kot so poročale šole, bistveno pripomogli $\mathrm{k}$ uspešni vključitvi učencev v pouk in druge šolske dejavnosti. Potekali so na izbranih šolah. Tečaji, ki so vključevali spoznavanje osnovnega besedišča in sporazumevalnih vzorcev, urjenje v vseh štirih jezikovnih spretnostih ter seznanjanje s sociokulturnimi vsebinami, so se izkazali za dobro rešitev pri začetnem učenju slovenščine. Šole so po končanih projektih želele nadaljevati s tako obliko začetnega poučevanja 
slovenščine, vendar zaradi finančnih omejitev takih tečajev po koncu projekta ni bilo več možno izpeljati (Knez, 2012).

Strnjeni uvodni tečaji so že prepoznani kot smiselno učenje novega jezika, za katerega izkušnje kažejo, da povečuje možnosti za uspeh, hitrejšo vključitev in napredovanje (Knez, 2012; Skubic Ermenc, 2010a; Bela knjiga, 2011). Vendar pa so v tem primeru priseljenski učenci izolirani od drugih učencev. Raziskave kažejo, da se v pripravljalnem razredu priseljenski učenci sicer naučijo osnovnega jezikovnega znanja, da pa mora biti segregacija kratka, sicer so učinki negativni (učenci ostajajo predolgo v teh razredih). Hkrati raziskave kažejo, da mora biti jezikovni tečaj povezan $\mathrm{z}$ učnim načrtom. Tudi K. Skubic Ermenc (2010a) opozarja pred segregacijo, saj je prav raziskava PISA pokazala, da so višji učni dosežki verjetnejši v enotnih kot pa $\mathrm{v}$ diferenciranih izobraževalnih sistemih, to pa pomeni, da diferencirani sistem razlike povečuje. Tako morajo biti cilj rešitev čim manj togega in tem bolj kratkotrajnega ločevanja učencev. Najmanj pa so učinki ločevanja škodljivi takrat, ko se prilagajanje pouka dogaja znotraj večinskega oddelka, torej pri notranji diferenciaciji in individualizaciji (Skubic Ermenc, 2010a, 271). Tudi Medveš (2006) na podlagi raziskav OECD in PISA zagovarja notranjo diferenciacijo, ki upošteva potrebo vsakega posameznika, torej zagovarja individualizacijo pouka.

V Beli knjigi (2011) se je stroka izognila segregaciji priseljenskih učencev in je kot rešitev predlagala strnjeni program slovenščine, $v$ katerem bi se učenci v določenem deležu udeleževali tudi rednega pouka skupaj s sošolci. Za program bi se oblikoval posebni učni načrt za slovenščino kot drugi/ tuji jezik. Tudi učitelji vidijo pozitivno stran intenzivnih tečajev slovenščine in jih podpirajo. Raziskava (Krek in Vogrinc, 2011) je pokazala, da večina osnovnošolskih učiteljev ( $88 \%$ ) meni, da bi morali učenci, katerih materni jezik ni slovenščina in slovenščine ne obvladajo, pred vključitvijo v slovensko osnovno šolo začetno znanje slovenščine pridobiti na posebnem intenzivnem tečaju. Več kot polovica osnovnošolskih učiteljev $(54,6 \%)$ meni, da bi morali učenci na takšnem tečaju pridobiti tudi osnovno znanje drugih predmetov.

\section{Pripravljalnica: uvajalnica in nadaljevalnica}

V zadnjih letih se pripravljalna faza pojavlja na posameznih šolah, na katerih je odstotek priseljenskih učencev višji. Na nekaterih šolah izvajajo "pripravljalnico «, ki jo sestavljata »uvajalnica i in »nadaljevalnica«. Uvajalnica se začne izvajati pred začetkom šolskega leta $\mathrm{v}$ zadnjem tednu avgusta. 
Namenjena je pomoči novopriseljenim učencem pri kulturnem in jezikovnem vključevanju v novo okolje. Novopriseljeni učenci se naučijo osnovnih sporazumevalnih vzorcev v slovenščini, spoznajo se s kulturno dediščino države gostiteljice ter vsebinami državljanske in domovinske vzgoje. Poleg tega lahko drugim predstavijo tudi svoj jezik in kulturo, se spoznajo $\mathrm{z}$ učitelji, učitelji pa se srečajo s starši (Jelen Madruša, 2010a; 2010b). Tako se poveča verjetnost, da se bo sodelovanje s starši ohranilo skozi vse leto. $\mathrm{V}$ nadaljevanju se spoznajo $\mathrm{z}$ učnimi in dnevnimi vsebinami, ki bodo del njihovega življenja v novem okolju (šola in življenje v šoli, potrebščine, predmeti in drugo). Tako se predpostavlja, da učenci v šolo pridejo manj prestrašeni, se počutijo varnejše in bolj sprejete, še pred začetkom šolanja pa se seznanijo tudi z novim jezikom (Jelen Madruša, 2010a; 2010b).

\section{Vrstniško in medvrstniško tutorstvo ter vrstniška pomoč}

Pri uspešnem vključevanju učencev priseljencev lahko ključno vlogo odigrajo tudi sovrstniki. Vrstniška pomoč, uporablja se tudi termin vrstniško tutorstvo, predstavlja obliko pomoči vrstnika vrstniku na različnih področjih (Dubois in Karcher, v Jereb, 2011). V Sloveniji kot vrstniško tutorstvo štejemo različne oblike sodelovalnega učenja $\mathrm{v}$ paru (pri tem medvrstniško tutorstvo pomeni tutorstvo med različno starima učencema, vrstniško tutorstvo pa med enako starima učencema), kot vrstniško pomoč pa različne oblike učenja v skupini enako starih učencev (Jereb, 2011, str. 95). Pri tutorstvu med različno starimi učenci tutor predstavlja model vzornega obnašanja, organiziranja dela, postavljanja vprašanj, predstavlja lastno učinkovito učenje in spodbuja izboljšanje učnih navad učenca, s katerim sodeluje (Gaustad; Miller in Miller, v Jereb, 2011). Na področju vključevanja učencev priseljencev je medvrstniško tutorstvo namenjeno učencem priseljencem kot dodatna pomoč pri razumevanju in usvajanju učne snovi posameznih predmetov pa tudi učenju slovenščine prek skupnega maternega jezika. Hkrati pa se, kot navajata Bešter in Medvešek (2010, str. 231), v določenih pogledih otrok lažje in hitreje identificira $\mathrm{z}$ vrstnikom kot $\mathrm{z}$ učiteljem in lahko zaradi tega bolje napreduje ob pomoči vrstnika. Medvrstniško druženje ne omogoča samo pomoči pri usvajanju učne snovi, ampak tudi lažje in hitrejše učenje nenapisanih pravil in norm obnašanja.

\section{Druge podporne oblike pomoči priseljenskim učencem $v$ Sloveniji}

Tudi nevladne in prostovoljske organizacije (npr. Slovenska filantropija, Mirovni inštitut, Inštitut za afriške študije ter številne druge ustanove, 
zavodi in društva) lahko še kako vplivajo na vsa področja življenja priseljenskih učencev in njihovih staršev. A. Mikuš Kos (1996, str. 36-37) meni, da lahko nevladne organizacije vplivajo na: (1) življenje in zdravje neposrednih porabnikov (npr. na otroke s psihosocialnimi motnjami, ki jim pomagajo prostovoljci, ali vplivajo na starše), (2) družino osebe, ki ji pomagajo (npr. na starše otroka $\mathrm{z}$ učnimi težavami, ki mu prostovoljec pomaga), (3) prostovoljne delavce (na občutek socialne koristnosti, zadovoljstva, osebnostne rasti, povezovanje $\mathrm{z}$ ljudmi, pridobivanje novih znanj in izkušenj), (4) socialnovarstvene in zdravstvene ustanove (na izboljšanje kakovosti delovanja, ugodnejša psihosocialna klima, večja motivacija bolnikov ali varovancev za zdravljenje ali aktivnosti, zmanjševanje psihičnih obremenitev osebja in podobno), (5) širšo družbo (glede vrednot, kot so odgovornost do lastnega ravnanja, osveščenost, solidarnostno vedenje in podobno), (6) zakonodajo, (7) uveljavljanje človekovih pravic in otrokovih pravic in (8) pokrivanje potreb (poskrbijo za nekatere potrebe, za katere država ne zmore poskrbeti oz. državi olajšajo izvajanje nekaterih dejavnosti). Avtorica poudarja, da nevladne in prostovoljske organizacije postajajo vse bolj pomembna ekonomska kategorija, ki ljudem pomaga na različne načine (npr. ustvarja nove socialne mreže, servise, nova delovna mesta).

V nekaterih osnovnih šolah v Sloveniji skušajo priseljenskim otrokom lajšati vzpostavljanje vezi s slovenskim jezikom tudi tako, da jim priskrbijo zasebne ure slovenščine, ki jih omogočajo prostovoljci z različnih oddelkov Filozofske fakultete. Spet druge šole poiščejo prevajalce, ki prevajajo šolske teste v materne jezike priseljenskih učencev (Mikuš Kos, 1996, str. 36-37). $\mathrm{V}$ nekaterih šolah poleg teh dejavnosti potekajo tudi druge aktivnosti (npr. strokovna pomoč/svetovanje šolam pri vključevanju priseljencev), ki jih izvaja Zavod republike Slovenije za šolstvo.

Podporne oblike pomoči priseljenskim učencem v šolski praksi se torej uresničujejo preko intenzivnih tečajev slovenščine pred vključitvijo $\mathrm{v}$ pouk, pripravljalnic, vrstniških in medvrstniških tutorstev, vrstniške pomoči in s pomočjo nevladnih in prostovoljnih organizacij, vendar je to prej izjema kot pravilo. Vključevanje priseljenskih učencev v vzgojno-izobraževalni sistem poteka predvsem $\mathrm{v}$ obliki dodatnega pouka slovenščine, ki je v slovenski zakonodaji različno opredeljen, dejanska praksa pa z zakoni ni vedno usklajena. Priseljenskim otrokom, za katere se ugotovi, da slovenskega jezika še ne znajo oz. ga še ne obvladajo dovolj, se praviloma odobri največ 1 ura dodatnega pouka slovenščine na teden, kar pomeni največ 35 ur na leto. Obseg ur za posameznega otroka glede na okoliščine določi 
Ministrstvo za izobraževanje, znanost in šport, način izpeljave pouka pa izberejo šole same. Posebnih zakonskih določil, kdo naj izvaja tak pouk in $\mathrm{v}$ kakšni obliki, ni (Strategija, 2007, str. 4).

\section{Pomanjkljivosti obstoječe slovenske zakonodaje in drugih strokovnih dokumentov}

Slovenska osnovnošolska zakonodaja omogoča, da se $\mathrm{v}$ osnovno šolo pod enakimi pogoji lahko vključijo vsi učenci, prav tako so izražene pravice priseljenskih učencev. Zakonodaja omogoča tečaj slovenščine, pouk maternega jezika in kulture (v sodelovanju $\mathrm{z}$ izvornimi državami) ter dveletno prilagojeno preverjanje in ocenjevanje znanja. Po pregledu zakonodajnih in drugih dokumentov, ki so podlaga za delovanje vzgojno-izobraževalnega sistema in za vključevanje učencev priseljencev, lahko zaključimo, da slovenski vzgojno-izobraževalni sistem vsebuje različne elemente medkulturnega pristopa, vendar je kljub temu zaznati nekatere pomanjkljivosti v zakonodaji. K. Skubic Ermenc (2010b, str. 85-86) je kritična do ciljev vključevanja, ki so našteti v Strategiji (2007) in Smernicah (2012), ter opozarja, da so priseljenski učenci obravnavani kot posebna kategorija, ki jih definira stopnja primanjkljaja (tj. stopnja obvladovanja slovenščine) ter da se večina ciljev nanaša nanje. Le cilj, ki predvideva medkulturno kulturo šole, v kateri se še posebej skrbi za dosežke priseljenskih učencev, se nanaša na celotno šolsko populacijo. K. Skubic Ermenc (2010b) opozori, da bi cilje lažje realizirali, če bi bilo osnovno izhodišče Strategije (2007) razvoj medkulturno zasnovane vzgoje in izobraževanja in ne vključevanje priseljenskih učencev. Priseljenski učenci imajo po vključitvi v redne oddelke osnovne šole le nekaj oblik podpore. Vendar pa slovenski avtorji in raziskovalci vzgoje in izobraževanja opozarjajo tako na pomanjkljivo zakonodajo kot neustrezno šolsko prakso (Lesar, 2009; Bešter in Medvešek, 2010; Mikulec, 2010; Lesar idr., 2012; Vezovnik, 2013), saj je velikokrat uspešno vključevanje priseljenskih učencev odvisno tudi od podpore in prizadevanja posameznega ravnatelja in/ali učitelja (Bela knjiga, 2011).

M. Vižintin (2010) in Bela knjiga (2011) opozarjata, da se priseljenski učenci ne učijo slovenščine kot drugega jezika, da je število ur za učenje slovenščine preskromno, za poučevanje slovenščine kot drugega jezika ni niti učnega načrta. Učenec priseljenec, ki ne obvlada jezika okolja, torej slovenščine, ima najverjetneje težave tudi pri drugih predmetih, hkrati pa tudi težave pri vključevanju $\mathrm{v}$ družbo. Tudi na področju učenja maternega jezika in kulture osnovne šole ne zagotavljajo uresničevanje pravic učencem, da 
se učijo svojega maternega jezika, saj le redke šole ponujajo učenje maternega jezika kot dopolnilno učenje, nekaj šol pa v sklopu izbirnega predmeta v tretjem triletju, pa še to gre za učenje tujega jezika. Učni načrti sicer predvidevajo medkulturne vsebine in učiteljem omogočajo, da jih lahko vpletejo v svoj predmet. O spoznavanju kultur priseljenskih učencev v slovenskih šolah I. Lesar (2009, str. 340) razlaga, da se skozi vidik prisotnosti drugih kultur v učnih načrtih obveznih predmetov postavlja resen dvom o možnosti spoznavanja in razvijanja oz. življenja lastne kulture teh učencev, saj je v kurikulih prepoznavna monokulturna naravnanost, ki se na ravni poučevanja izraža s proučevanjem kulturno drugačnih, ki so ekonomsko in socialno na slabšem. Vezovnik (2013) celo trdi, da se vključevanje, ki se navzven kaže kot demokratični poskus vključitve otrok, katerih prvi jezik ni slovenščina, v slovenske šole, v praksi izkaže za klasično asimilacijsko strategijo. Integracijska politika s svojimi ukrepi utrjuje dana razmerja moči v družbi in družbeni nadzor države in družbene večine nad manjšinskimi populacijami ter nastopa predvsem kot etnocentrična ideologija. K. Skubic Ermenc (2007) pa opozarja na zaskrbljujočo diskrepanco med tistim, za kar se javno zavzemamo, in med tistim, kar zares delamo in v sebi menimo. Splošna ugotovitev za slovensko šolo je, da kljub zavzemanju za integracijo in inkluzijo na ravni šolskega sistema (skladno z drugimi družbenimi sistemi) še vedno delujemo asimilacijsko. Želimo torej, da se vsi državljani in prebivalci Slovenije nasploh prilagodijo nam, da postanejo Slovenci (Skubic Ermenc, 2007, str. 134).

Pomanjkljivost obstoječega sistema se kaže tudi v tem, da Ministrstvo za izobraževanje, znanost in šport ne vodi evidence vpisanih priseljenskih učencev v osnovne šole. Na podlagi vlog šol za soglasje $\mathrm{k}$ uram dodatne strokovne pomoči (učenje slovenščine) za priseljenske učence, ki se prvo leto šolajo v Sloveniji, lahko Ministrstvo za izobraževanje, znanost in šport posredno in okvirno ugotovi le, koliko teh učencev se je všolalo v tekočem šolskem letu (Magdič in Straus, osebna komunikacija, januar in februar 2010; v Sinjur, 2010). Vrtci in šole ob vpisu priseljenskih učencev prav tako ne zapisujejo maternega (prvega) jezika otrok. Po podatkih, ki jih navaja Klinar (2010) je v osnovne šole v Sloveniji vključenih 5,2 \% otrok, katerih materni jezik ni slovenščina. Knaflič (2010) meni, da smo si s tako strogim režimom varovanja osebnih podatkov otežili preverjanje nepravičnosti sistema do jezikovnih manjšin. 


\section{Predlagani ukrepi in možne rešitve pri vključevanju priseljenskih učencev v vzgojno-izobraževalnih institucijah}

Učinkovitejše in pravičnejše vključevanje priseljenskih učencev v slovenski vzgojno-izobraževalni sistem je v veliki meri odvisno od znanja slovenščine. Bela knjiga (2011) predlaga tako obliko učenja slovenščine, ki jih bo motivirala ter omogočila hitro in učinkovito jezikovno napredovanje, hkrati pa učencev ne bo izključevala. Predlagajo bistveno povečano število skupnih ur in obvezno strnjeno obliko jezikovnega tečaja. Šola naj samostojno ali v sodelovanju $\mathrm{z}$ drugimi šolami na določenem območju oblikuje skupine za učenje maternega jezika in kulture za učence, katerih materni jezik ni slovenščina. Drugi materni jezik priseljenskih učencev bi se moral poučevati tako, da ga šole ponudijo kot izbirni predmet po posebnem kurikulu. Različni avtorji se strinjajo, da bi se sistematično učenje jezika okolja za priseljenske učence moralo začeti že pred vstopom v osnovno šolo. Tako bi učenci svoje znanje in razumevanje slovenskega jezika lahko začeli utrjevati že pred vstopom $\mathrm{v}$ formalno izobraževanje in bi se njihovi učni rezultati lahko izboljšali. S tem se strinja tudi B. Hanuš (2010), ki pravi, da bi morali učencem, ki so tukaj prvo leto, posvetiti več pozornosti, saj ob vključitvi v slovensko osnovno šolo potrebujejo več pomoči, ki jim je učitelji pri pouku ne morejo ponuditi. Vsi učenci bi morali biti že pred prvim šolskim dnem deležni pouka slovenščine. Predlaga tudi pripravo programov, ki bi poleg poučevanja jezika omogočali tudi spoznavanje slovenske kulture in kultur priseljenskih učencev. Strokovno izpopolnjevanje in dopolnilno izobraževanje so zanesljivi načini, kako se lahko izobraževalne ustanove učinkovito odzovejo na večkulturnost okolja in iščejo načine za navezovanje odnosov med posamezniki različnih kultur. Poleg samega učnega procesa, ki se odziva na njihove želje in potrebe, je nujno učencem priseljencem zagotoviti tudi udobnost v okolju, kjer se nahajajo. V Smernicah (2012) najdemo kar nekaj predlogov zagotavljanja medkulturnega okolja: zemljevidi sveta $\mathrm{z}$ označenimi državami izvora otrok priseljencev, pozdravi v jezikih otrok na hodnikih, prirejene brošure, spletne strani z vsaj osnovnimi informacijami $\mathrm{v}$ drugih jezikih, slikovne in besedne oznake otrok v šoli. Na področju sodelovanja s starši pa predlagajo pomoč pri izpolnjevanju vpisnih dokumentov, seznanitev staršev s pravicami in dolžnostmi, vključitev staršev v življenje in delo šole, ponuditi možnost učenja slovenskega jezika za učence in starše priseljence. Šola pomaga in sodeluje pri prevajanju, pripravi brošure za starše, spodbuja družinsko branje knjig, v knjižnici organizira tematska srečanja otrok in staršev. Tatković (2001) predlaga tudi vpeljavo nekaterih 
tem v učni proces, in sicer vzgoja za sprejemanje različnosti v jeziku, veri, stališčih, vedenju; spoznavanje drugih kultur in njihovih sestavin (gostovanja, izmenjave, ekskurzije); premagovanje predsodkov in socialnih stereotipov o posameznikih, ki pripadajo drugi kulturi; učenje jezika drugih kultur; uporaba nove tehnologije in medijev, s katerimi lahko znanje hitreje širimo. Kot smo izpostavili že zgoraj, je vzgoja v večkulturnih razredih uspešna le, če bodo v načrtovanje kurikuluma vključeni tudi starši. Starši so zadovoljni, če so vključeni v proces učenja svojih otrok, in lažje pomagajo svojim otrokom, ker jih bolje poznajo; na splošno imajo starši pri učenju drugega jezika zelo pomembno vlogo, saj lahko s svojim ravnanjem pozitivno vplivajo na otroka in prispevajo $\mathrm{k}$ njegovem uspehu s pohvalami in spodbudami (Knaflič, 1991).

Pri vključevanju priseljenskih učencev v slovenski vzgojno-izobraževalni sistem bi bila torej nujno potrebna aktivna podpora države, s konkretnimi ukrepi in sistemskimi rešitvami ter spodbudami, s katerimi bi pomagali pri vključevanju, saj lahko samo več sočasnih strokovno utemeljenih sprememb in ukrepov prinese rezultate.

\section{Literatura}

Bela knjiga o vzgoji in izobraževanju v Republiki Sloveniji. (2011). Krek, J. in Metljak, M. (ur.). Ljubljana: Zavod Republike Slovenije za šolstvo.

Berdajs, A. (2016). Socialnopedagoško delo učiteljev z rizičnimi dijaki v strokovnih šolah. V IV. International Scientific conference "Special education and rehabilitation - early intervention « (str. 196). Beograd: Beogradska defektološka škola.

Bešter, R., in Medvešek, M. (2010). Vključevanje migrantskih otrok v vzgojno-izobraževalni sistem. V M. Medvešek, in R. Bešter (ur.), Državljani tretjih držav ali tretjerazredni državljani?: integracija državljanov tretjih držav v Sloveniji (str. 205-269). Ljubljana: Inštitut za narodnostna vprašanja.

Direktiva Sveta $z$ dne 25. julija 1977 o izobraževanju otrok delavcev migrantov (77/486/EGS). Pridobljeno s http://eur-lex.europa.eu/legal-content/SL/ TXT/PDF/?uri=CELEX:31977Lo486\&qid=1406829546826\&from=EN

Hanuš, B. (2010). Jezikovne in kulturne ovire, ki vplivajo na opismenjevanje učencev priseljencev. Sodobna pedagogika, 61(1), 122-135.

Jereb, A. (2011). Strategije vrstniške pomoči za učence $\mathrm{z}$ učnimi težavami. V S. Pulec Lah in M. Velikonja (ur.), Učenci z učnimi težavami-izbrane teme (str. 94-110). Ljubljana: Pedagoška fakulteta. 
Jelen Madruša, M. (2010a). Iskanje poti pri delu z učenci migranti. V A. Baloh (ur.), Uvajanje rešitev s področja vključevanja migrantov v izvedbene kurikule (str. 7-19). Koper: Osnovna šola Koper/Scuola elementare Capodistria.

Jelen Madruša, M. (2010b). Novosti pri vključevanju učencev migrantov. V A. Baloh (ur.), Uvajanje rešitev s področja vključevanja migrantov $v$ izvedbene kurikule (str. 69-81). Koper: Osnovna šola Koper/Scuola elementare Capodistria.

Klinar, P. (2010). Medkulturno komuniciranje v šolskem prostoru. Socialna pedagogika, 14(2), 213-230.

Knaflič, L. (1991). Neslovenski otroci in šola. Jezikovni problemi otrok, ki se ne šolajo v maternem jeziku. Vzgoja in izobraževanje, 14(2), 38-41.

Knaflič, L. (2010). Pismenost in dvojezičnost. Sodobna pedagogika, 61(2), 280-294.

Knez, M. (2009). Jezikovno vključevanje (in izključevanje) otrok priseljencev. V M. Stabej (ur.), Infrastruktura slovenščine in slovenistike (str. 197-202). Ljubljana: Filozofska fakulteta.

Knez, M. (2012). Za koliko slovenščine je prostora v naši šoli? Jezik in slovstvo, $57(3-4), 47-62$.

Komac, M., Medvešek, M., in Roter, P. (2007). Pa mi vi povejte, kaj sem???! Študija o etnični raznolikosti v Mestni občini Ljubljana. Ljubljana: Fakulteta za družbene vede.

Konvencija o otrokovih pravicah (1989). OZN: Generalna skupščina OZN.

Krek, J., in Vogrinc, J. (2005). Znanje slovenskega jezika kot pogoj šolskega uspeha učencev iz jezikovno in kulturno različnih ter socialno depriviligiranih družin - primer začetnega opismenjevanja romskih otrok. Sodobna pedagogika, 56(2), 118-139.

Krek, J., in Vogrinc, J. (2011). Izbrani predlogi sistemskih rešitev v šolskem sistemu vidika socialne kohezivnosti. V B. Borota, M. Cotič, D. Hozjan in L. Zenja (ur.), Social cohesion in education (str. 79-93). Horlivka: Horlivka State Pedagogical Institute for Foreign Languages.

Lesar, I. (2009). Ali formalne rešitve na področju šolanja marginaliziranih omogočajo uresničevanje ideje inkluzije? Sodobna pedagogika, 6o(1), 334-348.

Lesar, I., Čančar, I., in Jug Došler, A. (2012). Učitelji iz Slovenije in Švedske o poučevanju (novo)priseljenih učencev. Dve domovini/Two Homelands, 36 , $59-72$. 
Magajna, L., Kavkler, M., Čačinovič Vogrinčič, G., Pečjak, S., in Bregar Golobič, K. (2008). Učne težave v osnovni šoli: koncept dela. Ljubljana: Zavod Republike Slovenije za šolstvo.

Medveš, Z. (2006). Upoštevanje drugačnosti - korak k šoli enakih možnosti. Sodobna pedagogika, 57(posebna izdaja), 10-41.

Mikuš Kos, A. (1996). Nevladne organizacije, prostovoljno delo in promocija zdravja. V E. Kraševec Ravnik (ur.), Varovanje zdravja posebnih družbenih skupin v Sloveniji (str. 25-41). Ljubljana: Inštitut za varovanje zdravja Republike Slovenije: Slovenska fondacija.

Pravilnik o preverjanju in ocenjevanju znanja ter napredovanju učencev $v$ osnovni šoli (2013). Uradni list RS, št. 52/2013. Pridobljeno 16. 10. 2013 s http:// www.uradni-list.si/1/objava.jsp? urlurid $=20131988$

Resolucija o nacionalnem programu za jezikovno politiko 2014-2018. Pridobljeno 16. 10. 2013, s http://pisrs.si/Pis.web/pregledPredpisa?id=RESO91

Sinjur, A. (2010). Učenci z imigrantskim ozadjem - politike in praksa učenja maternega jezika učencev imigrantov v nekaterih državah EU. Educa, 19(3-4), 59-69.

Skubic Ermenc, K. (2007). Interkulturnost v učnih načrtih slovenske osnovne šole. Pedagoška obzorja, 22(1-2), 128-135.

Skubic Ermenc, K. (2010a). Slovenska strategija vključevanja učencev migrantov v izobraževanje $\mathrm{v}$ kontekstu evropske izobraževalne politike. V N. Ličen (ur.), Kulture v dialogu (str. 79-89). Maribor: Grafiti Studio.

Skubic Ermenc, K. (2010b). Med posebnimi pravicami in načelom medkulturnosti. Sodobna pedagogika, 61(2), 268-279.

Strategija vključevanja otrok, učencev in dijakov migrantov $v$ sistem vzgoje in izobraževanja v Republiki Sloveniji (2007). Pridobljeno s http://www. mizks.gov.si/fileadmin/mizks.gov.si/pageuploads/podrocje/os/devetletka/ program_drugo/Smernice_izobr_otrok_tujcev_v_vrtcih

Tatković, N. (2001). Vzgoja za medkulturnost: usposabljanje za življenje v multikulturni družbi. Andragoška spoznanja, 7(2), 24-30.

UstavaSocialističnefederativnerepublikeJugoslavije.(1974).Odnosivfederacijiter pravice in dolžnosti federacije. Pridobljeno s http://sl.wikisource.org/wiki/ Ustava_Socialisti\%C4\%8Dne_federativne_republike_Jugoslavije_(1974)/ Odnosi_v_federaciji_ter_pravice_in_dol\%C5\%BEnosti_federacije

Vezovnik, A. (2013). Children whose first language is not Slovenian in the Slovenian educational system: A critical analysis of normalisation. Annales, Series historia et sociologia, 23(2), 303-316. 
Vižintin, M. A. (2010). Pouk maternega jezika in kulture pri učencih priseljencih. Sodobna pedagogika, 61(1), 104-120.

Vižintin, M. A. (2013). Vključevanje otrok priseljencev prve generacije in medkulturni dialog v slovenski osnovni šoli (Doktorska disertacija). Univerza v Ljubljani, Pedagoška fakulteta, Ljubljana.

Vižintin, M. A. (2014). Model medkulturne vzgoje in izobraževanja. Dve domovini/Two Homelands, 40, 71-89.

Zakon o organizaciji in financiranju vzgoje in izobraževanja (ZOFVI-UPB5) (2007). Uradni list RS, št. 16/2007. Pridobljeno s http://www.uradni-list.si/1/ objava.jsp? urlid=200716\&stevilka $=718$

Zakon o osnovni šoli (ZOsn) (1996). Uradni list RS, 12/1996. Pridobljeno s http:// www.pisrs.si/Pis.web/pregledPredpisa?id=ZAKO448

Zakon o spremembah in dopolnitvah Zakona o osnovni šoli (ZOsn-F) (2007). Uradni list RS, št. 102/2007. Pridobljeno s http://www.uradni-list.si/1/objava. jsp?urlid=2007102\&stevilka $=5073$ 


\title{
Vodenje in (neprofitni) menedžment v socialni pedagogiki
}

\author{
Andrej Berdajs \\ Univerza na Primorskem, Pedagoška fakulteta
}

\section{Uvod}

Organizacije, kjer se večinoma srečujemo s socialnopedagoško dejavnostjo, so predvsem vzgojni zavodi, vrtci, osnovne šole, srednje šole, stanovanjske skupine, centri za socialno delo, dijaški domovi, zapori, različne organizacije s področja dela $\mathrm{z}$ zasvojenimi, s težje zaposljivimi, $\mathrm{z}$ osebami s težavami v duševnem zdravju in različna društva ter nevladne organizacije. Socialni pedagog pri svojem delu vedno uporablja postopke in veščine vodenja. Ne samo takrat, ko je vodja kakšne od naštetih organizacij, pri svojem delu vedno vodi posameznike ali skupine skozi proces $\mathrm{k}$ zadanemu cilju. Kot osnovno mora obvladovati vodenje in organiziranje lastnega delovanja in razvoja. Predvsem mora biti vešč evalvacije lastnih postopkov, izmenjave izkušenj s kolegi in načrtovanja svojih korakov in uporabljanih metod pri svojem delu. Poznavanje in obvladovanje socialnih veščin mu je pri tem v veliko pomoč, ravno tako pa mora znati uporabljati osnovna pravila vodenja (menedžmenta).

V nadaljevanju bomo pregledali, kako je polje neprofitnih organizacij definirano $\mathrm{v}$ različnih državah in kakšne so njegove specifike $\mathrm{v}$ slovenskem prostoru. Poudarili bomo pomembne vsebine vodenja, kot so upravljanje s človeškimi viri, snovanje kulture neprofitnih organizacij in kaj je pomembno pri opredeljevanju organizacijske strukture. Opisali bomo posebnosti v snovanju vizije $\mathrm{v}$ neprofitnih organizacijah in izhodišča $\mathrm{v}$ pristopu 
do njihovega trženja. Opredelili bomo pomembnost ugotavljanja uspešnosti in usmeritve pri uvajanju sprememb v neprofitnih organizacijah.

\section{Posebnosti in vrste neprofitnih organizacij}

Temeljna opredelitev neprofitnih organizacij je, da služijo praviloma javnemu interesu ali interesu določenih skupin. Njihovo delovanje (in preživetje) je velikokrat odvisno od osnovnega pristopa države, ki se lahko bistveno razlikuje (Kolarič, 2001):

- $\quad$ lahko gre za liberalni tip sistema, kjer so v celoti prepuščene delovanju trga (ZDA, Avstralija);

- $\quad$ v konservativno-korporativističnem tipu sistema država primora večino državljanov, da se zavarujejo, sama pa nudi servis za tiste, ki tega ne zmorejo (Nemčija, Avstrija, Francija, Belgija);

- $\quad$ v socialdemokratskem tipu sistema država poskrbi za njegovo delovanje v celoti (skandinavske države);

- $\quad$ v katoliškem tipu je država v ozadju in pušča prostor, ki ga v večini pokrijejo cerkvene organizacije (Italija, Španija, Portugalska);

- $\quad$ v etatističnem tipu sistema država ne izpusti iz rok nadzora nad njim (postsocialistične države).

Vidimo, da se pristopi v različnih državah (tudi v okviru EU) zelo razlikujejo. Različna so tudi konkretna področja delovanja, ki jih pokrivajo neprofitne organizacije. Za Slovenijo velja, da je velika večina neprofitnih organizacij s področja kulture in rekreacije (športa) ter gasilska društva. Podoben odstotek je značilen tudi za druge srednjeevropske postsocialistične države. V ZDA, na Japonskem in Nizozemskem je večina neprofitnih organizacij s področja zdravstva. V Avstriji, Franciji, Nemčiji in Španiji prednjačijo socialne storitve. V Veliki Britaniji, Izraelu, Irski in Belgiji jih je največ na področju izobraževanja. Uravnoteženo zastopana področja najdemo na Finskem, v Avstraliji in Kolumbiji (Rončević, 2001).

Kot specifiko za Slovenijo lahko navedemo, da se še vedno pozna vpliv zaradi okoliščin, ko je v prejšnjem sistemu država (politika) obvladovala vse možne veje delovanja neprofitnih organizacij. Ob prehodu v nov sistem pa konstantno nastaja vrzel med realno prakso in nedodelano izvedbeno zakonodajo, iz katere izhaja veliko problemov, predvsem na področju angažiranja kadrov in odsotnosti spodbud davčnega sistema (Rončević, 2001).

$S$ finančnega stališča je glavna in osnovna razlika med profitnimi in neprofitnimi organizacijami ta, da je glavni cilj prvih ustvarjanje dobička 
glede na vložena sredstva, pri drugih pa je v ospredju izpolnjevanje njihovega poslanstva, medtem ko doseganje dobička ne igra glavne vloge.

S stališča dobrega vodenja (menedžmenta) vsako organizacijo vodimo $\mathrm{v}$ smeri, da bi v čim večji meri uresničili namene in cilje, zaradi katerih je bila ustanovljena. Ni pa tako bistvenih razlik, če je poudarek na materialnem dobičku, javnem ali zasebnem interesu ali na humanistično moralnih vrednotah (Jelovac, 2001).

Večina okvirov in smernic za delovanje neprofitnih organizacij je postavljena z določili Zakona o zavodih, Zakona o društvih idr. Osnovni cilji, ki so s pravnimi akti določeni ob ustanovitvi teh organizacij, so predvsem zadovoljevanje različnih družbenih potreb (finančni dobiček, kot smo že omenili, ne more biti glavno vodilo). Vse organizacije pa tako kot gospodarske družbe delujejo v okolju trga in so podvržene logiki bilance uspeha. Razumljivo in logično je, da se tudi v neprofitnih organizacijah tako imenovana prodaja storitev utemeljuje kot potrebna dejavnost, ki določa odnos do posameznih aktivnosti $v$ delovnem procesu. $V$ neprofitnih organizacijah je tako stalnica uskladitev pridobivanja sredstev (v okviru osnovne dejavnosti, z različnimi projekti ipd.) s poslanstvom osnovne dejavnosti. Problem se poglablja predvsem pri težavah s kadrovsko zasedbo in $s$ finančnimi sredstvi, ki jih je potrebno vložiti v projekte, ki morda ne bodo uspeli.

N. Hrovatin (2001) navaja, da neprofitne organizacije v izhodišču služijo širšemu družbenemu interesu. Po njenem so neprofitne organizacije lahko skupni pojem za vso javno upravo, za vse družbene dejavnosti in za prostovoljne organizacije, katerih poslovanje nima le cilja dobička. Če poslovanje organizacije pripelje do dobička, se le-ta praviloma vlaga v osnovno dejavnost organizacije.

To pomeni, da so neprofitne organizacije lahko vladne ali nevladne. Tako so pravne osnove za njihovo delovanje definirane ne le $\mathrm{v}$ zakonih o zavodih, ustanovah in društvih, ampak tudi v zakonih o gospodarskih družbah. Njihova področja, kjer se jih tradicionalno najde največ, so socialni sektor (brezdomstvo, okoljevarstvo, nasilje) in organiziranje družbenih dejavnosti (izobraževanje, šport, kultura, verske dejavnosti).

Osnova za njihovo operativno delovanje je poleg zakonskih aktov natančna definicija njihovega poslanstva. Definiranje poslanstva je izhodišče za določanje konkretnih nalog in aktivnosti. Tu nastane večji problem kot pri profitnih organizacijah, saj je praviloma potrebno zadovoljiti interese različnih uporabnikov (strank) in akterjev: otrok, staršev, "gojencev«, za- 
poslenih, stroke in države. $\mathrm{V}$ tem spektru je posebno pomembna vloga države, saj način in količina njene prisotnosti neposredno vpliva na obseg, $\mathrm{v}$ katerem se mora organizacija orientirati na svoj neposredni nastop na trgu (Hrovatin, 2001). Utemeljen je dvom, da bolj kot je organizacija usmerjena na trg in odvisna od njega, bolj se njena dejavnost oddaljuje od revnejših slojev družbe.

Kovač (2001) izhaja iz predpostavke, da ljudje zadovoljujejo svoje interese skozi trg, državo in civilno družbo. Razdelitev civilne družbe pa opravi na podlagi štirih vidikov:

- $\quad$ s formalnega vidika - dejavnosti delimo po poslanstvu na človekoljubne in tržne;

- $\quad$ z lastninskega vidika - dejavnosti civilne družbe so lahko vladne - javne službe ali privatne organizacije;

- $\quad$ z vidika vodenja - nekatere dejavnosti so profesionalno vodene, nekatere pa volontersko;

- $\quad$ z vidika končnih uporabnikov - nekatere dejavnosti so v javnem interesu, nekatere pa le v interesu ožjega članstva.

Avtor trdi, da neprofitni sektor (javna uprava, šolstvo, zdravstvo, kultura, šport in številne neformalne oblike civilne družbe) postaja čedalje pomembnejši segment družbe. Na vseh področjih ga opredeljuje tudi zelo velik preplet interesov. Kakor na eni strani razvoj globalizacije terja večji pomen civilnih institucij, tako na drugi strani kriza socialne države zahteva vedno bolj racionalne rešitve.

Osnovno poslanstvo socialne pedagogike - pomagati ljudem v stiski in področja delovanja socialnih pedagogov našo dejavnost v največji meri uvrščajo v sfero neprofitnih organizacij. V to domeno sodijo vse vzgojno-izobraževalne institucije (vrtci, osnovne šole, srednje šole, šole s prilagojenim programom, dijaški domovi), zavodi institucionalne vzgoje (vzgojni zavodi, zavodi socialnega skrbstva, varstveno delovni centri, zavodi za usposabljanje, zapori, prevzgojni domovi, mladinski domovi), zavodi socialnega varstva (domovi za starejše, krizni centri za žrtve nasilja, varstvo invalidov) ter v nevladnem sektorju področja humanitarnosti, preventivni programi, skupine za samopomoč in mladinsko delo. 


\section{Vodenje neprofitnih organizacij}

Teoretik znanosti vodenja in menedžmenta, Drucker (2001), izhaja iz dejstva, da se osnovni pristopi v menedžmentu profitnih ali neprofitnih organizacij ne razlikujejo.

Osnovni problem, ki v dobršni meri velja za vse neprofitne organizacije, je, da so kadrovsko podhranjene v segmentu strokovnih služb. Menedžer $\mathrm{v}$ neprofitni organizaciji mora večinoma sam opravljati dela pravnika, kadrovika, psihologa ipd. Za vsa ta področja nima na voljo posebnih strokovnih služb. Tako lahko zaključimo, da je vodenje neprofitnih organizacij s stališča vodje težje in predvsem bistveno bolj večplastno delo.

Zanimivo je tudi dejstvo, da pri vsakoletni izbiri menedžerja leta le-ta še nikoli ni bil izbran iz neprofitne organizacije. Prav tako nismo zasledili niti primera, da bi se uspešen menedžer iz gospodarstva preusmeril v neprofitni menedžment (za kar po vsej verjetnosti ni razlog le večja zahtevana heterogenost operativnega dela, ampak tudi drugačni razpoložljivi finančni okviri plače).

Težavnost vodenja neprofitnih organizacij morda povečuje tudi to, da ni jasne strateške vizije razvoje države, da se ne moremo izviti iz stalne krize izobraževalnega sistema in marginalnosti civilne družbe (Jelovac, 2001).

Pomen vodje za organizacijo je velik in se odraža na različnih področjih njenega dela in življenja. Njegovo delovanje se neposredno odraža na vtisu, ki ga organizacija daje navzven kot tudi navznoter do ostalih zaposlenih. Poleg koordiniranja dela, razdeljevanja nalog, nadzora nad izvedbo in ocenjevanja zaposlenih ima glavno vlogo pri snovanju vizije organizacije, načina njenega trženja ter skrbi in aktivno vpliva na kulturo in klimo, je snovalec in spodbujevalec sprememb.

\section{Upravljanje s človeškimi viri}

Upravljanje s človeškimi viri je proces, $\mathrm{v}$ katerem se $\mathrm{v}$ organizacijah na osnovi poslovne strategije načrtujejo potrebe po kadrih in $\mathrm{v}$ katerem se kadri zaposlujejo, razvijajo, vrednotijo, nagrajujejo in $\mathrm{z}$ njimi vzpostavljajo odnosi (Vodopivec, 2010). Pomembno je, da z znanjem, s spretnostmi zaposlenih upravljamo v skladu $\mathrm{z}$ njihovimi lastnostmi in cilji organizacije.

Upravljanje s človeškimi viri pomeni tudi, da zaposlenim pomagamo nadzirati in razvijati njihove lastne delovne kariere v sožitju s cilji organizacije (izobraževanje, usposabljanje, zastavljanje novih ciljev). Posebna 
skrb mora biti namenjena zaposlovanju novih delavcev in njihovemu uvajanju v delo.

Glede na to, da so neprofitne organizacije v večji meri storitvene, so človeški viri za njihovo dejavnost še bolj pomembni.

Vprašanja, na katera skušamo odgovoriti s pravilnim upravljanjem človeških virov v neprofitnih organizacijah, so po Svetliku (2001) naslednja:

- $\quad$ kako pridobiti zadosti ustrezno usposobljenih ljudi;

- $\quad$ kako iz njih izvabiti čim več ustvarjalne energije;

- $\quad$ kako doseči, da bodo svoje sposobnosti izpopolnjevali;

- $\quad$ kako jih v organizaciji obdržati - doseči, da jo bodo vzeli za svojo.

Vse to skušamo doseči $\mathrm{z}$ analizo delovnih procesov, s skrbjo za racionalno delitev dela, s stalnim spodbujanjem zaposlenih, $\mathrm{z}$ vlaganjem $\mathrm{v}$ njihovo izpopolnjevanje, s sprotnim ocenjevanjem njihovega dela in dosežkov.

Praviloma je $\mathrm{v}$ neprofitnih organizacijah denar kot motivacijsko sredstvo $\mathrm{v}$ večini primerov omejen, ob tem je največkrat število zaposlenih manjše od želja in potreb, in zato je nujno, da morajo zaposleni delati na več različnih področjih.

Ena osnovnih dilem je tudi ta, v kolikšni meri delovne potrebe pokrijemo $\mathrm{z}$ lastnimi kadri in katere dejavnosti ter v kolikšnem obsegu opravljamo z zunanjimi izvajalci.

Pri neprofitnih organizacijah, kjer so zaposleni socialni pedagogi, je s stališča upravljanja s človeškimi viri pomembna tista dimenzija, kjer skušamo doseči, da bodo le-ti svoje sposobnosti izpopolnjevali ter nadgrajevali svoje znanje in veščine s permanentnim dodatnim izobraževanjem ali funkcionalnim usposabljanjem. Možnost morajo imeti tudi za izmenjavo refleksij lastnega dela. Glede na to, da se večina socialnih pedagogov pri svojem delu s klienti stalno srečuje $\mathrm{z}$ lastnimi čustvenimi obremenitvami, jim je treba omogočiti supervizijo, kot njihovo stalno spremljajoče svetovanje. S tem preprečujemo stres in izgorevanja ob čustvenih in psihičnih obremenitvah.

\section{Kultura neprofitnih organizacij}

S kulturo organizacije označujemo definicijo socialne in fenomenološko unikatnost posamezne organizacijske skupnosti, ki vsebuje tako nematerialne kot materialne elemente (Beare, Caldwell in Millikan, 1992). Iz sociološkega vidika je kultura sistem dogovorjenih pomenov, spoznanj, simbo- 
lov in izkušenj, ki se izražajo v obnašanju in praksi članov organizacije, jih socialno definirajo ter jim dajejo občutek pripadnosti. Kultura organizacije pomeni način, kako le-ta deluje. Kultura ima osnovo v prepričanjih ljudi in njihovih vrednotah. Schein (1992) po Biloslavu (2007) kulturo organizacije določa na treh ravneh:

- na artefaktih ali pojavnih oblikah kulture (urejenost fizičnega okolja, uporabljan jezik in tehnologija, proizvodi, slog skupine (oblačenje, poimenovanja, izkazovanje čustev), legende o organizaciji, slovesnosti;

- na vrednotah (težnjah k privilegiranju nečesa pred drugim), velja, da so vrednote na meji med zavednim in nezavednim;

- $\quad$ na temeljnih podmenah (rešitve določenih situacij, ki jih organizacija privzame kot nesporne: vedenje, načini dojemanja ipd.).

Schein (1992) za posameznika pravi, da je njegovo vedenje odvisno od njegovih osebnih značilnosti in kulture organizacije, $\mathrm{v}$ kateri deluje. Posamezniki imajo generalno lahko operativno kulturo (izvajalci), inženirsko kulturo (načrtovalci procesov) in vodstveno kulturo (vodje).

Prav tako je kultura neke organizacije lahko močna (zanjo se zavzema večina članov) ali šibka (podpira jo le ožja skupina). Za uspešno delovanje organizacije in njeno rast je pogoj močna kultura (Biloslavo, 2007). Ob tem le-ta ni statična, temveč je v stalnem spreminjanju in dograjevanju.

Kultura organizacije, predvsem posamezne etape pri njenem ustvarjanju, je neposredno v rokah vodje. Le-ta se mora tega zavedati in jasno mu mora biti, h kašnemu cilju želi priti. Zaposleni vzpostavljajo niz splošno veljavnih mnenj o dogajanju v organizaciji in o vodji. Ta mnenja, ki se formirajo na podlagi v organizaciji veljavnih vrednot in stališč, niso nepomembna. Pogosto so razlog obnašanja in reakcij v odnosu zaposleni - vodja in zaposleni - uporabniki. Zato je prav, da vodja tega ne pušča vnemar in da se aktivno vključi v konstrukcijo vrednot in stališč določene (na primer, šolske) sredine.

Vsaka organizacija ima svojo lastno kulturo, ki je določena $\mathrm{z}$ individualnimi vrednotami, stališči in izkušnjami, ki jih prispevajo zaposleni. To nastane $\mathrm{z}$ načini, s katerimi zaposleni komunicirajo med seboj, in s sledmi, ki jih za seboj puščajo ti medosebni odnosi.

Robbins in Judge (2012) opredeljujeta organizacijsko kulturo kot skupno percepcijo, ki jo imajo člani organizacije. Pomeni sistem enakih pomenov, ki ločijo organizacijo od drugih organizacij. Gre za izbiro ključnih 
karakteristik, ki jih ima organizacija za vredne. Avtorja izpostavljata 10 karakteristik, ki se tičejo bistva kulture organizacij, in sicer:

- individualna iniciativa (stopnja odgovornosti, svobode in neodvisnosti posameznikov);

- $\quad$ toleranca tveganja (stopnja, do katere naj bi bili zaposleni agresivni, inovativni in naj bi tvegali);

- $\quad$ usmeritev (stopnja, do katere ustvarja organizacija jasne cilje in pričakovanja glede dela);

- integracija (do kakšne stopnje naj se enote $\mathrm{v}$ organizaciji integrirajo);

- podpora vodij (koliko vodje jasno komunicirajo, pomagajo in podpirajo podrejene);

- $\quad$ kontrola (število pravil in pravilnikov, stopnja direktnega nadzora nad zaposlenimi);

- identiteta (koliko se zaposleni identificirajo s celotno organizacijo - bolj kot recimo s svojim oddelkom ali s svojim poklicem);

- $\quad$ sistem nagrajevanja (koliko je ta sistem vezan na dosežke zaposlenih - namesto na delovno dobo, favoriziranje posameznikov in podobno);

- toleranca do konfliktov (koliko lahko zaposleni odkrito izražajo kritike in so konfliktni do vodij);

- $\quad$ komunikacijski vzorci (stopnja, do katere so komunikacijski vzorci omejeni na formalno hierarhijo in avtoriteto).

Vsaka od teh karakteristik je nekje na kontinuumu od nizke do visoke. Na podlagi teh karakteristik lahko ocenimo stanje in oblikujemo skupno sliko kulture organizacije. Seveda nam ta slika pove, kako zaposleni zaznavajo deset karakteristik, ne pa, ali so jim le-te všeč ali ne. Kultura organizacije je opisni pojem in po tem se loči od zadovoljstva s službo. Organizacijska kultura se ukvarja s percepcijo posameznih karakteristik, zadovoljstvo s službo pa s čustvenimi odzivi na delovno okolje (kultura organizacije je opisni pojem, zadovoljstvo s službo pa vrednostni).

$\mathrm{V}$ organizaciji pogosto ne obstaja enotna kultura. Obstaja dominantna kultura, ki izraža glavne vrednote, ki jih sprejema večina zaposlenih. Obstajajo pa tudi subkulture, ki se razvijejo po posameznih oddelkih. Do tega pride predvsem takrat, ko obstajajo lokacijsko oddaljene enote.

Robbins in Judge (2012) trdita, da je kultura lahko šibka ali močna. Močna je tedaj, če so glavne vrednote intenzivne in široko razširjene. 
Močna kultura povečuje povezanost vedenja. Je lahko nadomestek za formalizirana pravila in zato povzroča (brez napisanih pravil) predvidljivost v organizaciji, red in skladnost ter zmanjšuje fluktuacijo. Omejuje organizacijo od drugih organizacij, predstavlja identiteto članov, olajšuje upoštevanje širšega organizacijskega interesa, predstavlja sistem socialne stabilnosti (vedenje, nenapisana pravila) in stališča članov. Že ob vstopu v službo ima kultura velik vpliv na selekcijo kandidatov. Nekdo postane polnopravni član organizacije šele, ko sprejme kulturo organizacije. Za kulturo ne moremo reči, da je dobra ali slaba, ima pa veliko funkcij, ki so pomembne tako za organizacijo kot za posameznike. Lahko pa se tudi zaradi funkcije konsistentnosti in določanja vedenja posameznikov spremeni v »coklo« razvoja organizacije.

Beare idr. (1992) opozarjajo, da je kultura včasih v nesoglasju z deklariranimi cilji organizacije. Za močno in usklajeno kulturo je potrebna tesna povezava med nematerialnimi in konceptualnimi elementi ter materialnimi, zunanjimi izrazi in simboli.

Trenutne navade in tradicije $\mathrm{v}$ organizaciji so $\mathrm{v}$ glavnem posledica tega, kar se je že prej delalo in se je izkazalo za uspešno. Utemeljitelji kulture v organizaciji imajo največji vpliv na zgodnjo kulturo. Utemeljitelji imajo vizijo o tem, kaj naj bi organizacija bila. Ne omejujejo jih prejšnje navade ali ideologije. Kultura organizacije je rezultat interakcije med zamislimi in predpostavkami utemeljiteljev in tem, kar se zaposleni naučijo direktno iz lastnih izkušenj. Kulturo potem ohranja pri življenju proces selekcije kadrov, vodenje in socializacija delavcev znotraj organizacije (Robbins in Judge, 2012).

Socialni pedagog v naravi svojega delovanja - ko je njegova aktivnost usmerjena na osebo, ki je potrebna pomoči - ustvarja tudi kulturo svoje organizacije (institucije, zavoda), ki ji pripada. Z dobrimi odnosi, primernimi storilnostnimi pritiski in dosežki lahko gradi socialno kulturo, ki bo usmerjena $\mathrm{k}$ ljudem, njihovemu počutju in ne le rezultatom. Predvsem za reševanje problemov posameznikov, vključenih v organizacijo, je taka kultura najprimernejša.

\section{Organizacijska struktura}

Organizacijska struktura opredeljuje formalno ureditev organizacije glede razdelitev nalog, izvajalce nalog, njihove medsebojne odnose, pretok informacij ter linije avtoritete in vodenja (Vodopivec, 2010). 
Isti avtor loči formalno strukturo in neformalno, ki dopolnjuje funkcioniranje organizacije. Strukturo organizacije sestavljajo: tehnična struktura (razdelitev in združevanje delovnih nalog), komunikacijska struktura (smeri komunikacije, poročanje), motivacijska struktura (formalna in neformalna) in struktura vodenja (stopnje hierarhije, zadolžitve, pozicije posameznikov).

$\mathrm{Z}$ bolj dinamično dejavnostjo organizacije, njeno pojavo na trgu ali $\mathrm{z}$ razvojem se pojavi tudi potreba po drugačni in specifični organizacijski strukturi. Vodja mora pravočasno reagirati, predlagati in uvesti tako strukturo organizacije, da je prilagojena njenemu delu in življenju, da bo sam kot vrh te strukture svoje delo dobro opravljal.

Vodja mora znati vse večje in manjše skupine povezati v celoto, ki tvori organizacijo. Način tega povezovanja nam določi odnose - tako imenovano strukturo organizacije. Vodjo naj bi pri sprejemanju strukturnih odločitev vodili temeljni organizacijski koncepti, ki v glavnem veljajo za vse vrste organizacij. Ti temeljni organizacijski koncepti nam določajo vodenje organizacije. Pri snovanju strukture organizacije je potrebno upoštevati zakonske zahteve (predvsem v delu, ki določa soodločanje zaposlenih) in cilje organizacije.

Organizacijske strukture imajo otipljiv izraz v obnašanju in aktivnosti članov določene organizacije. Te strukture nam zelo nazorno prikazujejo poti odločanja, komunikacije, relacij moči in avtoritete, ki jih favorizira vodja kot »kreator« te strukture.

Lipičnik (1999) opozarja, da notranja organizacija in način njenega delovanja predstavljata glavna pogoja uspešnosti organizacije. Zato je pomembno, da ji posvetimo dovolj pozornosti. Vedno naj bi ju oblikovali cilji, naloge, nosilci nalog in njihova medsebojna razmerja. Cilji določajo naloge, ki jih morajo nosilci nalog izvršiti za doseganje cilja. Medsebojna razmerja med posameznimi sklopi ne smejo biti toga, ampak dovolj fleksibilna, da omogočajo hitro, učinkovito in stalno komunikacijo.

V organizacijski strukturi neprofitnih organizacij, kjer je zaposlenih več socialnih pedagogov, to daje možnost formiranja tima, ki poleg osnovnega sodelovanja in izmenjave izkušenj nudi tudi možnost skupnih refleksij in evalvacij njihovega dela. Če pa imamo v isti organizaciji zaposlene tudi druge strokovnjake iz različnih poklicev pomoči (socialni pedagogi, pedagogi, psihologi, socialni delavci), to omogoča osvetlitev problemov iz različnih zornih kotov. Sinergija in večplastni pogled na reševanje nekega proble- 
ma, ki lahko nastane ob taki organizacijski strukturi, sta izrazito pozitivna pri iskanju rešitev.

\section{Snovanje vizije organizacije}

Vizija delovanja neprofitne organizacije že na prvi pogled organizacijo loči od tiste, ki je profitno naravnana.

Načrtovanje razvoja organizacije je sestavljeno iz snovanja njene vizije in načrtovanja poti, ki nas pelje k uresničevanju le-te. Osnova za snovanje ali spreminjanje vizije organizacije mora biti fleksibilno odzivanje na spremembe v okolju, stroki, trgu in sistemu dela. Vizija je predstava o zaželeni prihodnosti. $\mathrm{V}$ osnovi mora zasnovati vizijo delovanja in razvoja organizacije njen vodja. Pomembno je, da vizijo konstruira na podlagi tako zunanjih dejavnikov kot tudi konkretne ekipe zaposlenih, ki bodo vizijo skupaj z njim udejanjili. Zato je potrebno, da posamezne segmente te vizije preigra in pretrese skupaj s posamezniki in skupinami, preden vizija dobi končno in potrjeno obliko. Nujno je, da se mora za uspešno delovanje organizacije v tej viziji videti vsak posameznik in vsaka skupina v organizaciji - ne sme biti to le vizija vodje. Resman (1994) poudarja, da ko snujemo vizijo razvoja organizacije moramo k delu pritegniti ne le zaposlene, temveč tudi ljudi iz okolja, v katerem organizacija deluje, in potencialne uporabnike, da ne bo vizija preveč abstraktna.

V. Vodopivec (2010) vizijo organizacije opredeljuje kot točko v prihodnosti življenja in delovanja organizacije. Njen namen je motivacijski naboj za zaposlene. Predstavlja kreativno pretvorbo poznavanja bodočih sprememb v okolju in sposobnosti organizacije za doseganje postavljenih smeri razvoja. Je slika možnega in želenega položaja organizacije v prihodnje. Bistveno je, da je konstruirana na osnovi realnih možnosti, da je taka, da jo razumejo in v njo verjamejo vsi zaposleni. Njen namen je: kontrola nad razvojem organizacije, oblikovanje strategije delovanja organizacije in spremembe kulture organizacije.

Skladno z vizijo organizacije morajo biti jasni tudi kratkoročni cilji. Medtem ko je vizija včasih bolj abstraktna, morajo biti kratkoročni cilji bolj pragmatični, usmerjeni v operativno akcijo. Konkretizacija vizije določa poslanstvo organizacije in nam pomaga pri definiranju (Vodopivec, 2010):

področij delovanja organizacije,

- koristnikov uslug organizacije,

- načina delovanja organizacije, 
- osnovnih vrednot in vzorcev obnašanja $\mathrm{V}$ organizaciji in $\mathrm{Z}$ okoljem.

Vizija kot tudi kratkoročni cilji niso nespremenljivi. Ene in druge je potrebno večkrat premisliti in ponovno preverjati. Vedno se je potrebno spraševati, ali še delamo to, kar smo želeli.

Vizija organizacije s socialnopedagoškim delovanjem je tako določena $z$ organizacijo nudenja pomoči neki ciljni skupini, ki to pomoč potrebuje, na optimalen način $z$ upoštevanjem etičnih načel in socialno sprejemljivih vzorcev vedenja v organizacijah in družbi.

\section{Trženje (marketing) v neprofitnih organizacijah}

Današnji koncept prostega trga opredeljujejo globalizacija in neoliberalni pristopi. Trg se od nadzorovanih postopkov vedno bolj premika $\mathrm{k}$ avtonomnosti. Situacijo na trgu najbolj opišejo pojmi, kot so: iniciativa posameznika, svobodna izbira, tekmovalnost, suverenost porabnika. Če želimo s trgom urejati področja, ki so glavna blaginja skupnosti in posameznika (šolstvo, zdravstvo in socialna varnost), to pomeni zaton socialne države (Trnavčevič, 2007).

$Z$ večanjem pomena trga se država umika tudi s področja nadzora nad organizacijami. Del nadzora naj bi se realiziral z različnimi koncepti ugotavljanja kakovosti, z eksternostjo rezultatov in poudarjenim vplivom menedžerjev. V praktičnem primeru imamo obliko trga, ki je definiran z možnimi izbirami odjemalcev in tekmo med polavtonomnimi izvajalci. Apeli nasprotnikov tržnih odnosov v smeri, »naj država uredi red na trgu in zagotovi socialne pravice ter enake možnosti«, se zavračajo $\mathrm{z}$ argumentiranjem, da moramo vzpostaviti primerljivost z drugimi državami EU (Trnavčevič, 2007).

Ko se organizacija pojavi na trgu, skuša koncipirati postopke in načine, kako bo s svojo dejavnostjo čim bolj odzivna na potrebe potencialnih odjemalcev. Trg seveda spodbuja tekmovanje med organizacijami $\mathrm{z}$ istega področja, kar lahko vpliva na rast kvalitete posamezne organizacije in bolj smotrno uporabo razpoložljivih sredstev. Država spodbuja vzpostavitev trga s spremembo zakonodaje in s spremenjenim financiranjem, ki omogoča večjo avtonomnost organizacij ter $\mathrm{z}$ spodbujanjem nastajanja zasebnih neprofitnih organizacij.

Marketing v neprofitnih organizacijah seveda vodi v večjo povezanost teh organizacij s profitnimi. Da so organizacije v takih partnerstvih uspeš- 
ne, morajo spreminjati svojo kulturo, prevzemati morajo pravila marketinških odnosov. Neprofitne organizacije za dosego svojih ciljev uporabljajo metode iz marketinških aktivnosti profitnih podjetij, ki so lahko tudi neučinkovite, če hkrati v organizacijah niso sprejeli tudi nove marketinške kulture. To seveda vodi v komercializacijo neprofitnega sektorja.

Tržno naravnana organizacija je po svoji kulturi poudarjeno pragmatična. Njene prednostne naloge delovanja določa zadovoljevanje potreb potencialnih odjemalcev (Snoj, 2007).

A. Trnavčevič (2007) opredeljuje, da trženje ali marketing organizacije pomeni naslednje: uzaveščenje, kaj je organizacija sposobna narediti; ugotovitev, kaj tvoji potencialni uporabniki želijo, potrebujejo ali so pripravljeni kupiti; doseči v zavesti potencialnega uporabnika, da je organizacija tisto, kar on želi, sposobna narediti; ter realizacija te produkcije $\mathrm{z}$ istočasnim informiranjem o aktivnosti organizacije. Vedno pa se moramo zavedati, kaj, zakaj in komu tržimo.

Logaj (2007) meni, da ima marketing neprofitne organizacije naslednje specifike: zagotoviti mora vnaprej določene socialne zahteve in operirati mora $\mathrm{v}$ tržnem okolju, ki je pogosto omejeno s poudarjenimi cilji organizacije.

Marketinške dejavnosti se začno $\mathrm{z}$ ugotovitvijo potreb in želja potencialnih uporabnikov in $\mathrm{z}$ definicijo trenutnega stanja delovanja organizacije. Iz teh izhodišč predlagamo in načrtujemo potrebne nove dejavnosti. Pomembna vloga vodje je, da spodbuja zaposlene in pripomore k spremembi organizacijske kulture tako, da postane marketinška naravnanost interes vseh.

V trženju socialnopedagoških uslug izhajamo iz vnaprej določenih socialnih zahtev, ki jih družba ali organizacija pričakuje od prejemnikov teh uslug, ter njihovih primanjkljajev, ki jim to onemogočajo ali otežujejo.

\section{Ugotavljanje uspešnosti neprofitnih organizacij}

V nobeni organizaciji, profitni ali neprofitni, ne moremo meriti uspešnosti le s finančnim dobičkom na podlagi številk iz bilance uspeha. Uspešnost organizacije določajo tudi različna kvalitativna merila (Jelovac, 2001).

Dejstvo je, da se merila in izhodišča ugotavljanja uspešnosti za profitne organizacije (gospodarske družbe) in neprofitne organizacije prepletajo. Instrumenti in načini merjenja uspešnosti neprofitnih organizacij morajo praviloma izhajati iz v osnovi definiranega poslanstva organizacije. 
Večinoma gre za kvalitativne elemente, ki so taksativno težje ugotovljivi (na primer zadovoljstvo). Prav je tudi, da jih kombiniramo s kvantitativnimi elementi (uspeh, število obravnavanih primerov) in splošen rezultat ugotavljamo na osnovi evalvacije.

M. Tekavčič (2002) navaja, da so ugotovitve o uspešnosti delovanja organizacije osnova, na kateri lahko $v$ organizaciji uvajamo spremembe $\mathrm{v}$ strategiji in konkretnih odločitvah $\mathrm{v}$ zvezi z delovanjem organizacije. Uspešnost organizacije moramo kvantitativno meriti in tudi kvalitativno presojati. Pri tem moramo opraviti naslednje korake: ločitev bistvenih aktivnosti od nebistvenih, analiziranje pomembnih bistvenih aktivnosti, primerjava opravljenih aktivnosti z najboljšimi znanimi primeri dobre prakse in preučevanje povezav med aktivnostmi.

Tudi pri socialnopedagoški dejavnosti lahko uspešnost delovanja opredeljujemo s kvantitativnimi kazalci, ki nam dajejo podatke o številu (uspešno ali neuspešno) obravnavanih primerov (oseb). Merilo za vsebinsko ugotavljanje uspešnosti socialnopedagoškega delovanja pa so kvalitativni kazalci, s katerimi ugotavljamo uspešnost in zadovoljstvo prejemnikov uslug oziroma primerjavo našega delovanja s primeri dobre prakse.

\section{Uvajanje sprememb v organizacije}

Splošna situacija v družbi, navade, življenjski stili, globalizacija, tehnološki in informacijski napredek pogojujejo stalno zahtevo po spremembah v vseh družbenih segmentih. A. Sinjur (2009, str. 362) pravi, »da morajo biti učitelji pri svojem delu ustvarjalni in fleksibilni, da lahko konstruktivno rešujejo težave, ki se pojavljajo znotraj pedagoškega procesa, in tako dosegajo vzgojno-izobraževalne cilje«.

Enako je pri vsaki drugi organizaciji - ne glede na panogo njene dejavnosti. Vsaka organizacija, ki želi izboljšati svojo uspešnost, mora spodbujati stalno učenje vseh svojih članov in jim s tem omogočiti napredek ter primeren odziv na potrebne spremembe (Erčulj, 1998).

Pri uvajanju sprememb moramo upoštevati trenutno stanje organizacije, njeno kulturo in klimo, značilnosti in zmožnosti zaposlenih.

Za uvajanje sprememb bi lahko uporabljali izraz organizirano izboljševanje dejavnosti. Seveda pa moramo v naprej definirati, kaj za neko sredino, organizacijo pomeni uspešnost (Drucker, 2001).

Vsaka sprememba v večji ali manjši meri ruši ravnotežje nekega stanja in s tem predvidljivost in varnost delovne situacije. S strani zaposlenih 
je velikokrat zaradi tega odziv odpor in strah. Zato je nujno, da vodja zaposlene pripravi na uvajanje sprememb, tako da novi okviri pomenijo izziv, ne pa le probleme in ovire.

Cilji vpeljevanja sprememb v življenje in delo organizacije so izboljšanje kakovosti delovanja posameznikov kot organizacije (Rupnik Vec in Rupar, po Schollaert, 2013). Važna je seveda smiselnost predvidenih sprememb. Bolje je, da vpeljujemo le tiste, ki pomembno in trajno prispevajo k izboljšanju uspešnosti organizacije. Spremembe niso uspešne, če zaposleni, ki naj bi spremembe vpeljevali, nimajo vpliva na njihovo načrtovanje (Schollaert, 2006).

Cilji sprememb morajo biti vedno usklajeni $\mathrm{z}$ vizijo organizacije in vedno morajo biti merljivi (Tavčar, 2002). Vodja mora vse zaposlene angažirati že tedaj, ko se definirajo cilji organizacije, da jih sprejmejo kot svoje. Uvajanje sprememb in razvojna aktivnost brez vizije je praviloma trošenje energije in časa brez pravega smisla.

Za kreiranje vizije je v osnovi zadolžen vodja. Pomembno pa je, da jo konstruira tako na podlagi zunanjih dejavnikov kot tudi konkretnih značilnosti in sposobnosti zaposlenih, $\mathrm{s}$ katerimi bo to vizijo skupaj v prihodnosti realiziral. Vizija pa ne sme biti le vizija vodje. V njej se mora videti vsak posamezni zaposleni. Ugodno je, da vsi zaposleni na pobudo vodje neposredno sodelujejo pri opredeljevanju posameznih segmentov vizije.

Skladno z vizijo organizacije morajo biti definirani tudi kratkoročni cilji delovanja. Medtem ko je vizija lahko malo bolj abstraktna, morajo biti kratkoročni cilji povsem pragmatični, osnova za konkretno akcijo. Vedno pa moramo imeti v zavesti, da tako vizija kot kratkoročni cilji niso nespremenljivi. Ene in druge je potrebno večkrat preveriti in premisliti njihovo utemeljenost.

Demokratičen pristop k uvajanju sprememb da bistveno več možnosti, da vsi zaposleni sprejmejo in aktivno delajo v postopkih njihovega uvajanja.

Koren (2006, po Nader, 1998) loči med stalnimi spremembami s ciljem odprave problemov delovanja organizacije in izboljšanja uspešnosti ter radikalnimi spremembami, ki so vezane na strategijo delovanja organizacije in njenih struktur.

Schollaert (2006, po Van Dougen, De Laat in Maas, 1996) loči tri vrste sprememb, in sicer:

radikalne spremembe (gre za izboljšavo v tehničnem smislu delovanja organizacije); 
- adaptivne spremembe (tu vpeljujemo novosti, ki ne zahtevajo sprememb v mišljenju);

- razvojne spremembe (ne gre le za spremenjeno ravnanje, ampak za nova stališča, pojmovanja, prepričanja, za razvoj novih kompetenc).

Drucker (2001, po Dimovski, 2005) glede uvajanja sprememb predpostavlja naslednja izhodišča: vsako spremembo je treba uvajati postopno, pred uvedbo spremembe pretehtajte stroške in zagotovite potrebna sredstva, spremembe ne smejo nasprotovati identiteti organizacije in stalno nagrajujte tiste, ki največ prispevajo $\mathrm{v}$ procesu uvajanja sprememb.

$\mathrm{V}$ današnjih časih uvajanje sprememb $\mathrm{v}$ organizacijo ni projekt $\mathrm{z}$ opredeljenim končnim rokom. Stalne spremembe dejavnikov okolja zahtevajo tudi stalnost sprememb v organizacijah, če te želijo ohranjati svoj položaj v prostoru (ali ga celo izboljševati).

Zelo pomemben del uvajanja sprememb je evalvacija (Štrajn, 200o). Z vrednostnim, količinskim in kakovostnim tehtanjem rezultatov neke nove dejavnosti, ki smo jo vpeljali v delo šole, dobimo učinkovite informacije o smotrnosti uvedbe sprememb. Postopek evalvacije in načrtovanja naslednjih korakov, ki sledijo iz nje, je proces, kjer se lahko omogoči veliko sodelovanja med zaposlenimi. Evalvacija po Schollaertu (2006) je smiselna med posameznimi akcijskimi koraki vpeljevanja sprememb in naj bi skušala odgovoriti na naslednja vprašanja:

- $\quad$ Ali smo še vedno na pravi poti?

- $\quad$ Ali se približujemo cilju?

- $\quad$ Ali naš cilj še vedno ostaja tak, kot smo si ga zamislili?

- Kaj je treba storiti, da pridemo na pravo pot?

- Kaj smo do sedaj že dosegli?

- Kaj je dokaz tega?

- Kaj smo se naučili iz vsega tega?

Sprememba, ki ne povzroči odpora, sploh ni sprememba, ampak nadaljevanje stanja, ki trenutno ustreza večini (Tavčar, 2002).

Razlogi za odpor so (Tavčar, 2009, po Robbins, 1991) ogrožene koristi (odvzemanje ali razvrednotenje dosedanjih koristi), sprememba utečenih navad, ogrožena varnost (nova tveganja), strah pred neznanim, sprejemanje le tistih dejstev o spremembah, ki se ujemajo z njihovimi navadami. 
Odpore zaposlenih do uvajanja sprememb lahko zmanjšamo ali čisto odpravimo z naslednjimi aktivnostmi (Koren, 2006, po George in Jones, 1999):

- $\quad$ z intenzivno in kvalitetno komunikacijo z zaposlenimi (odpori se velikokrat porajajo zaradi pomanjkanja informacij);

- $\quad$ z izobraževanjem in usposabljanjem na področjih, kjer uvajamo spremembe (odpori so velikokrat posledica nevednosti);

- $\quad$ s sodelovanjem čim večjega kroga zaposlenih in pooblaščanjem posameznikov za posamezne aktivnosti (distribucija moči);

- $\quad$ s podporo zaposlenim (svetovanje, izobraževanje);

- $\quad$ s pogajanji in dogovarjanjem (vodja tako dobi odziv zaposlenih na svoje ideje);

- $\quad \mathrm{z}$ manipulacijo (selektivno informiranje kot preprečevanje oviranja procesa sprememb);

- $\quad s$ prisilo (s tem pospešimo uvedbo sprememb, a velikokrat ob nezadovoljstvu zaposlenih, ki sprememb ne vzamejo za svoje).

Slabosti in nevarnosti, ki jih zaposleni vidijo v uvajanju sprememb, lahko s primerjalno analizo spremenimo v prednosti in izzive (Škrinjarič, 2006). Zavedati se pa moramo, da so za uspešno vpeljavo sprememb v kolektiv potrebni tudi kompromisi med vsemi, ki so vanje vpleteni. A. Sinjur (2009, str. 365) pravi, »da mora učitelj v pogojih globalne družbe, poleg pedagogike, menedžmenta in vodenja $\mathrm{v}$ izobraževanju, obvladati še vrsto drugih sposobnosti in spretnosti«.

Zelo važna je stalna in intenzivna komunikacija med vsemi člani kolektiva s ciljem prenosa informacij in znanja (diskusije, predavanja) ter iskanjem najustreznejših rešitev za probleme. Na začetku procesa je potrebno definirati pričakovanja, želje, se soočiti z morebitnimi strahovi in pomisleki. Odločilno vlogo v postopku uvajanja sprememb v kolektivu ima lahko tako imenovani razvojni tim, ki reflektira nameravane spremembe in procese njihovih vpeljevanj, zagotavlja izmenjavo informacij med zaposlenimi (Rupnik Vec in Rupar, 2013). Med člani takega tima je dobro, da so tisti, ki so odprti za spremembe, ki se radi učijo in ki znajo spodbujati tudi druge. Tak tim lahko bistveno vpliva na ustvarjanje pozitivne klime za spremembe (Rupnik Vec in Rupar, 2013). Tim reflektira nameravane spremembe, zbira, pripravlja in razvija podporna gradiva, zagotavlja in spodbuja izmenjavo mnenj med člani kolektiva. Osnovno delo takega tima 
je utemeljitev smiselnosti sprememb (Rutar Ilc, 2008). Nujno je, da kolektiv zaupa v vodstvo in morebitni tim za uvajanje sprememb.

Vodja se mora angažirati, da ustvarja primerno okolje, ki je naklonjeno uvajanju sprememb. Zaposleni so načeloma zelo zainteresirani, da vplivajo na delovanje organizacije $v$ prihodnje, saj bodo sami del tega delovanja. To, da gredo vsi člani kolektiva skupaj skozi proces kreiranja vizije organizacije, daje vsem odgovornost in jim dviguje moč za lastno delovanje. Njihove strahove in nemir pred novitetami mora vodja $\mathrm{z}$ razumevanjem sprejeti. Vseskozi je zaposlene potrebno osveščati, da bo večina rezultatov sprememb vidna šele po določenem času (predvsem, če s spremembami posegamo v kulturo organizacije).

Vpeljevanje sprememb $\mathrm{v}$ organizacijo s socialnopedagoško dejavnostjo lahko pogojujemo s spremembami, ki so ji podvržene ciljne skupine našega delovanja (na to v veliki meri vpliva splošno stanje v družbi). Najbolj koreniti in vsebinski premiki naše dejavnosti pa so odvisni od razvoja stroke in vpeljevanja novih organizacijskih pristopov in praks $\mathrm{v}$ socialnopedagoško delovanje.

\section{Sklep}

Ugotavljamo, da se socialnopedagoška dejavnost v največji meri realizira na polju neprofitnih organizacij. Ob tem velja, da vodenje neprofitnih organizacij danes doživlja intenzivne spremembe predvsem na segmentu marketizacije vseh področij. Tržna naravnanost dejavnosti neprofitnih organizacij bistveno vpliva na njihovo delovanje. Zato lahko zaključimo, da je s stališča vodenja teh organizacij prvi pomembnejši segment upravljanje s človeškimi viri, kjer je cilj, da vodja zna izbrati prave osebe za konkretna delovna mesta ter da stalno skrbi za njihovo motiviranost in možnosti profesionalnega razvoja. Prav tako je potrebno, da se $\mathrm{v}$ teh organizacijah vzpostavi socialna kultura, ki bo posameznikom (tako tistim, ki nudijo pomoč, kot tistim, ki jo sprejemajo) prijazna. V organizacijski strukturi moramo omogočiti formiranje strokovnega tima, ki bo osnova za izmenjavo izkušenj in skupne evalvacije dela. Tudi v snovanju vizije in poslanstva neprofitnih organizacij s socialnopedagoško dejavnostjo moramo biti usmerjeni v optimalno nudenje pomoči različnim ciljnim skupinam. Ne smemo dopustiti, da zaradi zahtev trga zanemarjamo potrebe uporabnikov, zaradi katerih je bila neprofitna organizacija ustanovljena. Glede na generalno poslanstvo neprofitnih organizacij, ki je v večini primerov usmerjeno k zadovoljevanju javnih družbenih potreb, je velikokrat težko obravnavati produkte njiho- 
vega delovanja kot izdelke ali usluge, ki so podvrženi tržnim zakonitostim. Če pogledamo polje socialnopedagoške dejavnosti, ki je usmerjena k delu s socialno šibkejšo, problematično in velikokrat marginalizirano populacijo, pretirano uvajanje tržnih zakonitosti lahko privede do zmanjševanja ali celo zapiranja socialnopedagoških uslug delu populacije, ki te usluge najbolj potrebuje. Ugotovimo lahko tudi, da je pomembno poznavanje kvantitativnih in predvsem kvalitativnih kazalcev našega dela, na podlagi katerih lahko ocenimo uspešnost delovanja. Zaključimo lahko, da s pravočasnim in aktualnim uvajanjem sprememb na podlagi novih družbenih zahtev ali novih doktrin stroke zagotavljamo, da naše socialnopedagoško delovanje ostane aktualno in da $\mathrm{z}$ njim dosegamo zastavljene cilje.

\section{Literatura}

Beare, H., Caldwell, B., in Millikan, R. (1992). Creating an excellent school. Some new management techniques. London: Routledge.

Biloslavo, R. (2007). Kultura organizacije. V A. Trnavčevič (ur.), Ko država šepeta (str. 29-56). Koper: Fakulteta za management.

Dimovski, V. (2005). Učeča se organizacija. Ljubljana: GV založba.

Drucker, P. (2001). Managerski izzivi v 21. stoletju. Ljubljana: GV založba.

Erčulj, J. (1998), Učeča se organizacija - izziv za učiteljev strokovni razvoj. Ljubljana: Vzgoja in izobraževanje, 29(3), 21-25.

Hrovatin, N. (2001). Ekonomski vidiki menedžmenta nevladnih organizacij. V D. Jelovac (ur.), Jadranje po nemirnih vodah managementa nevladnih organizacij (str. 36-46). Ljubljana: Zavod Radio Študent.

Jelovac, D. (2001). Odisejada krmarjev neprofitnega sektorja. V D. Jelovac (ur.), Jadranje po nemirnih vodah managementa nevladnih organizacij (str. 2-10). Ljubljana: Zavod Radio Študent.

Kolarič, Z. (2001). Različni znanstveno-teoretski pristopi k preučevanju neprofitnih organizacij. V D. Jelovac (ur.), Jadranje po nemirnih vodah managementa nevladnih organizacij (str. 11-22). Ljubljana: Zavod Radio Študent.

Koren, M. (2006). Ključni dejavniki uspešnosti uvajanja sprememb v podjetje v slovenskih razmerah (Magistrsko delo). Univerza v Ljubljani, Ekonomska fakulteta, Ljubljani.

Kovač, B. (2001). Lobiranje v neprofitnem sektorju. V D. Jelovac (ur.), Jadranje po nemirnih vodah managementa nevladnih organizacij (str. 108-115). Ljubljana: Zavod Radio Študent.

Lipičnik, B. (1999). Organizacija podjetja. Ljubljana: Ekonomska fakulteta. 
Resman, M. (1994). Ravnatelj in vizija šole. Sodobna pedagogika, 45(3-4), 122-132.

Robbins, P. S., in Judge, T. A. (2012). Organizational behaviour. Englewood Cliffs, NJ: Prentice Hall.

Rončević, B. (2001). Različni znanstveno-teoretski pristopi k preučevanju neprofitnih organizacij. V D. Jelovac (ur.), Nekaj nastavkov za sociološko obravnavo nevladnih organizacij (str. 23-35). Ljubljana: Zavod Radio Študent.

Rupnik Vec, T., in Rupar, B. (2013). Vpeljevanje sprememb v šole. Ljubljana: Zavod Republike Slovenije za šolstvo.

Schollaert, R. (2006). Pomen sprememb v izobraževanju. Vpeljevanje sprememb v šole: konceptualni vidiki. Ljubljana: Zavod Republike Slovenije za šolstvo.

Sinjur, A. (2009). Menedžment učiteljeve administracije. V M. Blažič (ur.), Menedžment v pogojih globalne recesije (zbornik prispevkov) (str. 361-366). Novo Mesto: Visoka šola za upravljanje in poslovanje.

Snoj, B. (2007). Marketinška kultura. V A. Trnavčevič (ur.), Ko država šepeta (str. 57-80). Koper: Fakulteta za management.

Svetlik, I. (2001). Menedžment človeških virov v neprofitnem sektorju. V D. Jelovac (ur.), Nekaj nastavkov za sociološko obravnavo nevladnih organizacij (str. 47-52). Ljubljana: Zavod Radio Študent.

Škrinjarič, K. (2006). Projekti v šoli - vodstveni izziv. V T. Taštanovska (ur.), Mednarodni projekti $v$ šoli: Priročnik za ravnatelje (str. 6-14). Ljubljana: CMEPIUS, Ministrstvo za šolstvo in šport.

Štrajn, D. (200o). Evalvacija. Ljubljana: Pedagoški inštitut.

Tavčar, M. (2002). Strateški management. Maribor: Ekonomsko-poslovna fakulteta, Inštitut za razvoj managementa.

Tavčar, M., (2009). Management in organizacija. Sinteza konceptov organizacije kot instrumenta in kot skupnost interesov. Koper: Fakulteta za management.

Tekavčič, M. (2002). Merjenje in presojanje uspešnosti poslovanja. V S. Možina (ur.), Management - nova znanja za uspeh (str. 664-693). Radovljica: Didakta.

Trnavčevič, A. (2007). Marketinška kultura v šoli. V A. Trnavčevič (ur.), Ko država šepeta (str. 13-28). Koper: Fakulteta za management.

Vodopivec, V. (2010). Osnove upravljanja in organizacija poslovanja. Ljubljana: Leila. 


\title{
Refleksija socialnopedagoškega diskurza osnovnošolskih praks
}

\author{
Ana Bogdan Zupančič \\ Univerza na Primorskem, Pedagoška fakulteta
}

\section{Uvod}

Med profile zaposljive na osnovni šoli (v nadaljevanju OŠ) je bil socialni pedagog zakonsko umeščen leta $1996 \mathrm{z}$ Zakonom o osnovni šoli in natančneje 2011 s Pravilnikom o izobrazbi učiteljev in drugih strokovnih delavcev $v$ izobraževalnem programu osnovne šole. Na podlagi zakonskih (ZOsn, 1996; 2016) in podzakonskih določil (Pravilnik o izobrazbi učiteljev in drugih strokovnih delavcev $v$ izobraževalnem programu osnovne šole, 2011) je v praksi socialni pedagog $\mathrm{v}$ osnovni šoli prisoten na delovnih mestih svetovalnega delavca, učitelja za dodatno strokovno pomoč (v nadaljevanju DSP) (predvsem za otroke $s$ težavami na čustvenem in vedenjskem področju ${ }^{1}$ ), učitelja individualne in skupinske pomoči ( $v$ nadaljevanju ISP) za učence $\mathrm{z}$ učnimi težavami, učitelj v jutranjem varstvu (v nadaljevanju JV) ter kot učitelj v organiziranem podaljšanem bivanju (v nadaljevanju OPB).

$\mathrm{Na}$ ta način profil pokriva širok diapazon področij dela, kjer je veliko priložnosti za socialnopedagoško (predvsem vzgojno) delovanje, katerega

1 V Kriterijih za opredelitev vrste in stopnje primanjkljajev, ovir oz. motenj otrok s posebnimi potrebami (Vovk Ornik, 2015) so tovrstne težave še vedno opredeljene kot čustvene in vedenjske motnje. V prispevku pa smo se odločili za uporabo pojma težave in ne motnje, saj le-ta zajema širšo skupino otrok in mladostnikov ter poudarja možnost prehodnega značaja in razrešitve, o čemer piše Vec (2011), ki predlaga kontinuum čustvenih, vedenjskih in socialnih težav, kjer predlaga boljši kriterij določanja težavnosti/motenosti, glede na to, koliko je otrok, mladostnik sposoben zadovoljevati osnovne psihosocialne potrebe. 
bistven element je socialnopedagoški odnos (Krajnčan in Bajželj, 2008), ki se vzpostavi med profesionalcem, socialnim pedagogom in otrokom $/ \mathrm{mla}$ dostnikom. Gre torej za profesionalni odnos, za katerega sta ključna odnosna kompetentnost in profesionalni razvoj (Juul in Jensen, 2010) strokovnega delavca, če naj bi šlo za čustveno stabilen, sprejemajoč, kvaliteten in stabilen odnos.

Med kompetencami, ki naj bi jih študentje socialne pedagogike pridobili tekom študija, so tudi kompetence za vzpostavljanje profesionalnih odnosov (Dekleva, Kobolt in Klemenčič Rozman, 2006), zato omenjeni strokovni delavci obetajo visoko mero odnosnih, komunikacijskih in socialnih kompetenc. To jim omogoča suveren vstop v osnovnošolski prostor, vendar hkrati odpira številna vprašanja povezana $z$ vnosom kompetenčnega diskurza v vzgojo in izobraževanje (Štefanc, 2012). Poleg omenjenih vprašanj se na področju socialnopedagoškega delovanja v osnovnošolskem prostoru soočamo s pomanjkanjem pravno formalne veljave, ki se kaže v odsotnosti družbenoemancipatorne vloge socialnih pedagogov (Zorc Maver, 2006) in v prilagajanju le-teh prevladujočim psihološko-medicinskim diagnostičnim modelom obravnave otrok s posebnimi potrebami (v nadaljevanju OPP), še posebej ko gre za eno od najbolj ranljivih skupin otrok s čustvenimi in vedenjskimi težavami, motnjami (Opara idr., 2010). Tak status socialne pedagogike na sistemski ravni onemogoča zagotavljanje inkluzivnega okolja in aktivnejše vključevanje v dejavnosti zgodnjega odkrivanja in primarne preventive kot ključnih smernic za uspešno socialnopedagoško prakso v osnovni šoli.

S pomočjo pregleda različnih sodobnih socialnopedagoških, filozofskih in pedagoških izhodišč ter nekaterih zakonskih smernic želimo v prispevku pregledati in analizirati obstoječe osnovnošolske prakse. Hkrati pa je naš namen nakazati alternative, potenciale socialnopedagoškega diskurza na področjih vzgojnega, družbenoemancipatornega, pravno-formalnega, inkluzivnega in preventivnega delovanja.

\section{Socialni pedagog kot glasnik pomembnosti kakovostnih profesionalnih odnosov $\mathbf{v}$ osnovni šoli}

Spodbuden, čustveno sprejemajoč odnos z otroki/mladostniki je osnova za vedenjsko in učno prilagajanje, uspešnost v osnovni šoli (Vidmar in Kerman, 2016) ter tudi uspešno pomoč (Krajnčan in Bajželj, 20o8). Tudi Galimberti (2015) zapiše, da bi učitelji morali vedeti, da je čustvena sprejetost predpogoj za kognitivni razvoj. Za čustveno sprejemanje, spodbudne, 
profesionalne in kakovostne odnose sta zelo pomembna profesionalni razvoj in odnosna kompetenca (Juul in Jensen, 2010; Vernooji, 1995), ki omogočata samokritično refleksivnost in sta del profesionalizacije, o kateri govori Müller (1983).

Juul in H. Jensen (2010) trdita, da profesionalnega razvoja ni mogoče povsem ločiti od osebnostnega. Tudi Krajnčan in Bajželj (2008) menita, da (socialni) pedagog vzgaja s svojo celotno osebo, kjer je ločnica med osebnim in profesionalnim včasih zabrisana. Kar pomeni, da "pri vsakem profesionalnem delu z ljudmi igrajo za kakovost profesionalnega odnosa pomembno vlogo strokovnjakova osebna karizma, njegov značaj in sposobnost uveljavitve " (Juul in Jensen, 2010, str. 175). Gre za vzajemno vplivanje obeh vidikov - profesionalni vpliva na osebnostnega in obratno (Juul in Jensen, 2010, str. 175).

Odnosno kompetenco Juul in H. Jensen (2010) definirata kot sposobnost odraslega, učitelja, vzgojitelja, da »vidi« otroka, mladostnika kot edinstveno in enakovredno človeško bitje, da je sposoben voditi otroka/mladostnika, da je pri tem avtentičen in hkrati prevzema polno odgovornost za odnos. Je torej sposobnost posameznika, da vzpostavi enakovreden odnos $\mathrm{z}$ otrokom/mladostnikom, ki temelji na dialogu (Juul in Jensen, 2010), spodbuja avtorefleksijo, osebno emancipacijo in družbeno solidarnost, o kateri govori Rutar (2002). Profesionalna ravnanja, ki izhajajo iz omenjene sposobnosti "zahtevajo « tudi visoko mero poznavanja samega sebe, lastnega čustvovanja in vedenja (predvsem v stresnih situacijah), če naj gre za zavestno vzgojo in izobraževanje (Gardner, po Galimberti, 2015)

Postavlja se vprašanje, ali so socialni pedagogi profesionalno (tudi osebnostno) in odnosno kompetentni avtonomno zagovarjati pomembnost kvalitete odnosov in čustveno sprejemajoče klime na osnovni šoli? Ali gre za kompetence, ki naj bi bile »sin qua non« odločitve za študije, poklice, kjer so temelj odnosi z ljudmi, in ali jih je možno razviti tekom študija? Tudi tu zopet pridemo do tesne povezanosti profesionalnega in osebnega (Juul in Jensen, 2010; Krajnčan in Bajželj, 2008), ki pa ne sme biti »izgovor« za profesionalne napake in nereflektirano prakso študentov in kasneje strokovnih delavcev.

Glede na značilnosti socialnopedagoške doktrine, kjer gre za delovanje od spodaj navzgor, usmerjenost $\mathrm{v}$ življenjski prostor posameznika (Grunwald in Thiersch, 2008; Krajnčan, 2006; Razpotnik, 2014) in hermenevtični pristop k diagnostiki (Rapuš Pavel, 1999), bi od socialnega pedagoga v OŠ pričakovali, da bo zgled enakovrednosti in medsebojnega pri- 
znavanja partnerjev, spoštovanja v procesu pomoči (Grunwald in Thiersch, 2008). Z zavedanjem pomembnosti kvalifikacije v vzpostavljanju odnosov, torej $\mathrm{z}$ ozaveščenim profesionalizmom, kjer bo znal razpoznavati in nadzorovati odnosno polje na šestih področjih ${ }^{2}$ (Krajnčan in Bajželj, 20o8): osredinjenost na naloge in osebe, simetrija in asimetrija odnosa, fleksibilnost in doslednost, prevzemanje in predajanje odgovornosti, zadržanost in angažma, bližina in distanca, bo lahko kot vzor in usmerjevalec ohranjal socialno in vzgojno v šolskem polju.

\section{Vzgojna vloga socialnega pedagoga $\mathrm{v}$ osnovni šoli}

V Zakonu o osnovni šoli (2006, 2. člen) so zapisani vsaj trije vzgojni cilji, če se osredotočimo samo na tiste, ki se začnejo z pojmom vzgajanje, in sicer:

- $\quad$ "vzgajanje in izobraževanje za trajnostni razvoj in za dejavno vključevanje v demokratično družbo, kar vključuje globlje poznavanje in odgovoren odnos do sebe, svojega zdravja, do drugih ljudi, svoje in drugih kultur, naravnega in družbenega okolja, prihodnjih generacij;

- $\quad$ vzgajanje za obče kulturne in civilizacijske vrednote, ki izvirajo iz evropske tradicije;

Krajnčan in Bajželj (2008) omenjena področja natančneje razložita: pri osredinjenosti na naloge in osebe gre za to, da se strokovnjak glede na potrebe otroka/mladostnika odloča, koliko bodo v ospredju odnosi (z različnimi osebami) in koliko naloge, ki jih mora otrok/mladostnik opraviti. Pri simetriji in asimetriji govorimo o hierarhičnosti odnosa med strokovnim delavcem in otrokom/mladostnikom, ki je zaradi odgovornosti in vodenja strokovnega delavca le redko simetričen (ko nihče ni v podrejenem položaju), bolj lahko govorimo o komplementarnosti odnosa. Kljub pomembnosti doslednosti pri delu $\mathrm{z}$ otroki/mladostniki s čustvenimi in vedenjskimi težavami, motnjami, je pomembno, da strokovni delavec zmore tudi fleksibilnost, pripravljenost na popuščanje, prilagajanje, spreminjanje določenih dogovorov, pravil glede na situacije in potrebe otroka/mladostnika, saj se le tako ohranja možnost dialoga v odnosu. Pri prevzemanju in predajanju odgovornosti strokovni delavec presodi, kdaj se lahko umakne in preda odgovornost in možnost izkušenj otro$\mathrm{ku} / \mathrm{mladostniku} \mathrm{in} \mathrm{kdaj} \mathrm{mora} \mathrm{prevzeti} \mathrm{iniciativo} \mathrm{ter} \mathrm{voditi,} \mathrm{ker} \mathrm{otrok/mladostnik}$ tega še ne zmore ali ne zna. Področje zadržanosti in angažmaja je zelo blizu področju odgovornosti, s tem da se prvo usmerja bolj na aktivno sodelovanje otroka/mladostnika, ki ga strokovni delavci spodbudijo s tem, da ne izvajajo pritiska nanj v obliki pretiranega lastnega vložka, da mu dajo dovolj časa in so torej zadržani v odnosu z njim, če je potrebno. Med najbolj zahtevnimi področji pa je zagotovo področje med bližino in distanco, saj se tu strokovnjak nahaja v konstantnih notranjih konfliktih med tem, koliko bližine v odnosu dovoliti, da ne bo prišlo do odvisnosti otro$\mathrm{ka} / \mathrm{mladostnika}$ od strokovnega delavca, in hkrati, kako preseči distanco, ki onemogoča vzgojno delovanje $\mathrm{v}$ odnosu $\mathrm{z}$ otrokom/mladostnikom. 
- $\quad$ vzgajanje za obče kulturne in civilizacijske vrednote, ki izvirajo iz evropske tradicije."

Bela knjiga o vzgoji in izobraževanju (Krek idr., 2011, str. 14) opredeljuje, da je temeljni cilj vzgoje in izobraževanja »oblikovanje razmišljujočega in odgovornega posameznika, ki se opira na kakovostno pridobljeno znanje in socialne ter druge spretnosti.« Med splošnimi cilji med drugim navaja tudi, da mora slovenski vzgojno-izobraževalni sistem spodbujati optimalni razvoj posameznika, razvijati zmožnosti za vseživljenjsko učenje, kamor sodi razvijanje delovnih navad in odgovornosti za svoj razvoj, za svoje zdravje, zagotavljati enake možnosti za vzgojo in izobraževanje vsakega posameznika s posebno pozornostjo na ranljive skupine (priseljenci, otroci in mladostniki s posebnimi potrebami in tisti iz socialno in kulturno manj spodbudnega okolja) ter razvijati zmožnosti za življenje v demokratični družbi, kamor sodi tudi vzgajanje za vrednote strpnosti, solidarnosti in spoštovanja.

Predvidevamo, da so številni vzgojni cilji osnovne šole omogočili, da se je profil socialnega pedagoga uveljavil v slovenskem šolskem prostoru. Tako Skalar (1993) poudarja, da delo socialnega pedagoga v OŠ prispeva $\mathrm{k}$ humanizaciji odnosov, kar pomeni, da v ospredju ni samo izobraževalna temveč tudi vzgojna naloga. S tem temeljna komponenta socialnopedagoškega dela postaja socialnopedagoški odnos kot sestavni del vzgajanja (Krajnčan in Bajželj, 20o8).

Socialni pedagog v OŠ vstopa v prvi vrsti kot vzgojitelj, kjer so v ospredju vzgojni cilji, kar je lahko protiutež storilnostno usmerjeni, na izobraževalne, zgolj učne cilje naravnani šolski kulturi. Cilj socialnopedagoškega odnosa je (str. 57) »vzgoja in izobraževanje mladih prek celotne pedagoške osebe, saj se osebni duh razvija samo skozi osebnega duha.« S tem pa se že dotaknemo področja pedagoškega etosa in erosa, kjer prav tako vidimo pomembno vloga socialnega pedagoga v OŠ.

Pedagoški etos ustanove, o katerem govori Giesecke (v Krajnčan in Bajželj, 2008), je v vrednostnem konsenzu znotraj vzgojne (tudi izobraževalne) institucije, ki omogoča, da so moralna načela v vzgojnem delu nekaj samoumevnega. Pri pedagoškem erosu pa gre predvsem za odnos, neke vrste brezpogojno sprejemanje, neseksualno ljubezen med vzgojiteljem (učiteljem, socialnim pedagogom) in vzgajanim (Krajnčan in Bajželj, 2008). Oba omenjena koncepta sta sestavni del vzgojno-izobraževalnega okolja tudi v slovenskih OŠ. Vsekakor pa ne smemo zapasti v grandiozna prepričanja o vsemogočnosti socialnopedagoške stroke, ki sama ne more prevzeti 
odgovornosti za etos vzgojno-izobraževalnih ustanov in tudi ne za pedagoški eros zaposlenih v odnosu do otrok/mladostnikov, vzgajanih, lahko pa ponudi pomembno podporo in je eden izmed gradnikov tovrstne kulture.

Ravno zato, ker bi se radi izognili grandioznosti, idealiziranju, bomo v nadaljevanju v duhu samorefleksivne socialne pedagogike kritično ovrednotili vlogo in delo socialnega pedagoga $\mathrm{v}$ slovenskem osnovnošolskem sistemu.

\section{Socialni pedagog kot podaljšana roka osnovnošolskega} izobraževalnega sistema ali javni intelektualec

»Tako v mednarodnem kot tudi v slovenskem prostoru se je na nacionalni ravni kurikularnega načrtovanja uveljavil učno-ciljni pristop, ki izhaja iz anglo-saksonskega prostora.« (Štefanc, 2012, str. 94). Avtor navaja nekatere problematične učnike omenjenega pristopa, o katerih govorita Kelly (po Štefanc, 2012) in Kroflič (po Štefanc, 2012), ki so v tem, da vzgojo in izobraževanje reducirajo zgolj na mehanicistično pojmovano znanstveno aktivnost. To kritiko učno-ciljne naravnanosti lahko povežemo za Galimbertijevo (2015) kritiko usmerjenosti šole zgolj na znanstveno-tehnokratsko inteligentnost. Pri obeh so v ospredju točno določeni učni cilji, ki služijo kot kriterij usvojenega znanja, pri čemer so procesi in doživljanja vpletenih v učenje postranskega pomena.

Če upoštevamo avtorjevo razmišljanje, da se v osnovni šoli daje prednost konvergentni inteligentnosti, ki spodbuja enoznačne odgovore, se lahko vprašamo, kakšne učence, dijake in študente taka šola spodbuja, vzgaja ali, če se izrazimo neoliberalistično, "producira«? Ali se socialni pedagogi v času študija, kot pravi Rutar (2016), v šoli premaknejo s točke, ko morajo ugotavljati, katere (enoznačne) odgovore želi slišati učitelj, profesor? Osnova za kritično, avtonomno držo in ustvarjalno razmišljanje, ki presega enoznačne odgovore, ki si upa govoriti tudi o »norih«, novih idejah, vidikih, argumentih je divergentna inteligentnost, za katero Galimberti (2015) pravi, da je v šoli manj cenjena, čeprav je bolj zanimiva in značilna za ustvarjalne. Kako pa je s to inteligentnostjo v času študija in ali sistemska ureditev podpira tovrsten način ustvarjalnosti?

Cilj procesa vzgoje in izobraževanja, ki je zapisan v Beli knjigi o vzgoji in izobraževanju (2011), je »oblikovanje« avtonomnega, samostojnega posameznika, ki je sposoben argumentiranega, ustvarjalnega dialoga $\mathrm{z}$ drugimi na spoštljiv način. Kot tak je sposoben kritične, (avto)refleksivne drže 
in prevzemanja odgovornosti za lastne odločitve, neodvisno od avtoritete (Juul in Jensen, 2010). Tu se nam zastavlja več vprašanj: ali je to sposobnost, ki jo razvijamo in spodbujamo $\mathrm{z}$ doseganjem zgolj pričakovanih rezultatov (enoznačnih odgovorov) na testih znanja, in če ne, na kakšen način jo spodbujamo in razvijamo, torej, kako (slovenska) osnovna šola spodbuja ustvarjalen način razmišljanja in razvoj avtonomne osebnosti in kakšno vlogo ima lahko pri tem socialni pedagog?

Galimberti (2015) govori o mnogoterih inteligentnostih, kjer se naslanja na Gardnerja (1991) in se sprašuje, kam nas vodi, danes prevladujoča, znanstveno-tehnična inteligentnost. Nas pa zanima, če je ta oblika inteligentnosti prevladujoča tudi na študiju socialne pedagogike in z razvijanjem katerih kompetenc jo študij želi preseči, razširiti? Glede na analizo doseženih in zaželenih kompetenc socialnih pedagogov, ki so jo opravili Dekleva idr. (2006), lahko ugotovimo, da si socialnopedagoški diskurz prizadeva za preseganje tehnicističnega, dualnega sistema razmišljanja tudi s poudarjanjem pomembnosti osebnostnih, odnosnih, socialnih in komunikacijskih kompetenc. Ravno zato smisel študija in kasneje dela socialnega pedagoga vidimo tudi v tem, da bi uspel pozivati šolnike, kot jih poziva Galimberti (2015), da naj ne uničujejo različnih oblik inteligentnosti, v katerih se skrivajo možnosti za razvoj človeškosti, ki je s pomembnostjo odnosa temelj socialnopedagoškega dela. Kako opremljeni s »človeškostjo« pa pridejo dijaki na študij socialne pedagogike?

Avtor pod vprašaj postavi merjenje inteligence in uspeha v OŠ in kot argument navaja izjemnost nekaterih genijev, ki so bili v OŠ v povprečju učno neuspešni. Ne govorimo o tem, da bi socialna pedagogika potrebovala genije, menimo pa, da bi potrebovala kader, ki bi bil sposoben kritičnega presojanja, iskanja alternativnih rešitev za sistemske ovire, še posebej v osnovnošolskem prostoru.

Rutar (2016) piše o tem, da slovenska OŠ ni prilagojena kognitivnim znanostim in da njeni sistemi poučevanja, učenja in ocenjevanja ne spodbujajo razmišljanja, zato učenci razvijejo samoobrambni refleks, ki ga številni ohranijo tudi v odraslosti, in sicer o tem, da ni dobro preveč razmišljati. Ali lahko socialni pedagog, ki je šel sam čez tak izobraževalni sistem in je bil na študij izbran po merilnih učne uspešnosti, sam orje ledino k sodobnejši šoli, ki bo spodbujala razvoj samostojnih, avtonomnih posameznikov, ki jim bo mar za druge? Ga študij usposobi za javnega intelektualca $\mathrm{v}$ javnem prostoru, o katerem govori Jacoby (po Rutar, 2017)? 
Glede na precej neprepoznavno pozicijo socialne pedagogike in socialnih pedagogov $\mathrm{v}$ javnem prostoru bi lahko sklepali na pomanjkanje javnih intelektualcev s tega področja. To je le ena od številnih priložnosti in nalog visokošolskega izobraževalnega sistema, da izkoristi svoj intelektualni potencial za izstop iz sistemskih okvirov in nauči bodoče socialne pedagoge razmišljati ter s tem oblikuje javni socialnopedagoški prostor.

Socialna pedagogika je sicer $\mathrm{v}$ javnem, šolskem prostoru prisotna že 25 let. $\mathrm{V}$ tem obdobju se je zelo uveljavila $\mathrm{v}$ praksi, ne pa toliko $\mathrm{v}$ teoriji, kar se kaže v pomanjkanju znanstvenih prispevkov z osnovnošolskega področja. To lahko pomeni, da študij usposablja ustrezen kader, ki izpolnjuje zahteve trga dela, s čimer je na nek način podvržena ekonomskemu razmišljanju, o katerem govori Laval (2005). Na tak način tudi študij oz. visokošolski izobraževalni sistem postaja podoben OŠ, ki je »zaradi prevlade vrednot učinkovitosti in koristnosti izobraževanja vedno bolj podrejena interesom, ki oblikujejo trg dela, kar pomeni nevarnost, da bo postala organizacija za zagotavljanje storitev in dobrin za posameznika kot potrošnika, ki bo po svoji presoji izbiral na svobodnem trgu izobraževalnih storitev.» (Štremfel, Barle Lakota in Polak, 2014, str. 13, 14). Zaradi omenjenega sta v ozadju izobraževanje kot javna dobrina in temeljna človekova pravica, vzgojna funkcija OŠ (Štremfel idr., 2014, str. 13, 14), hkrati pa je vzgojno-izobraževalni sistem premalo osredotočen na razvoj demokratičnih intelektualcev, o katerih govori Rutar (2002), s sposobnostjo avtorefleksije, osebne emancipacije in družbene solidarnosti.

Kljub temu, da v Sloveniji socialna pedagogika še nima prepoznavne identitete in doktrine, pravno formalne vrednosti in odgovora na vprašanje, koliko je socialna in koliko pedagogika, koliko psihologija in koliko specialna pedagogika, kar se še posebej odraža v šolskem prostoru, vidimo ravno na tej točki priložnost za kritično refleksivno socialnopedagoško delovanje. Socialna pedagogika ima namreč interdisciplinarni kot tudi transdisciplinarni karakter (Bouillet in Uzelac, 2007), kar ji omogoča prestopanje meja znotraj posameznih znanstvenih disciplin in povezano, usklajeno, interaktivno raziskovanje in delo. Na ta način se natančneje definira kot samostojna znanstvena disciplina in strokovni profil in se izogne nevarnosti psihologizacije in psihiatrizacije, na katero opozarja Skalar (1993).

Po drugi strani pa je disperznost socialnopedagoške prakse sicer lahko pokazatelj fleksibilnosti posameznikov, ki so postali socialni pedagogi, vendar hkrati onemogoča avtonomno strokovno držo, saj jih v šolskem prostoru velikokrat potisnejo v vlogo »deklice za vse« (glede na raznoli- 
ka delovna mesta in naloge, ki jih lahko opravljajo) ali pa šolskega »gasilca« težav.

Tako Skalar (1993), kot eden od utemeljiteljev socialne pedagogike v Sloveniji, kot Krajnčan (1997), ki razvija predvsem področje socialnopedagoške metodike $\mathrm{v}$ zavodski vzgoji (tudi v OŠ), socialnega pedagoga v OŠ vidita kot avtonomnega strokovnjaka $\mathrm{z}$ jasno vizijo in programom. Grünfeldovi (1997) v svoji razpravi o socialnem pedagogu v OŠ zagotovo ne manjka vizije, saj opredeljuje nekatera dela in naloge socialnega pedagoga izven priporočil in smernic svetovalnega dela. Zelo velikopotezno zastavi program dela, ki naj bi se bistveno razlikoval od programa dela drugih strokovnih delavcev, vendar pozabi na nekatere zakonske oz. sistemske ovire, ki lahko zelo vplivajo na delovno motivacijo socialnega pedagoga, še posebej na začetku poklicne poti.

Poleg tega, da za tako sistemsko pozicijo socialni pedagog potrebuje podporo javnega prostora, ki bi v tem primeru moral biti naklonjen njegovi emancipacijski družbeni vlogi kot nosilki sprememb (Zorc Maver, 2006), je nujno upoštevati tudi tisto bolj psihološko, individualno komponento motive za izbor poklica ter opremljenost za soočanje $\mathrm{z}$ obstoječo prakso, kjer v kapitalistični družbi žal vse preveč deluje le kot stabilizator oz. korektor (Zorc Maver, 2006).

Zagotovo na socialnopedagoško udejstvovanje, poleg drugih pomembnih dejavnikov, vpliva tudi faza profesionalnega razvoja (Valenčič Zuljan, 2001). Menimo, da ima socialni pedagog $\mathrm{v}$ fazi novinca in začetnika, kljub jasni viziji in programu, drugačno izhodišče, kot tisti, ki je že nekaj časa zaposlen in ima na delovnem mestu status izkušenega. Pri tako zahtevni nalogi, kot je uveljavljanje lastnega programa, je zelo pomembno, da bodoče študente naučimo tudi. na kakšne ovire lahko naletijo pri tovrstnem aktivizmu.

Z razmišljanjem o priložnostih in ovirah ne moremo mimo socialnopedagoškega razvrščanja in diagnostike OPP v OŠ. Ta sicer ima svojo strokovno utemeljeno vizijo, vendar pa, verjetno tudi zaradi že omenjene težave glede pravno formalne veljavnosti stroke, zanjo v OŠ še ni zadostnih priložnosti.

\section{"Konkurenčnost" socialnopedagoške diagnostike}

V OŠ ravno zaradi velike tendence $\mathrm{k}$ psihološko medicinskemu pristopu, še posebej pri diagnosticiranju in obravnavi otrok s posebnimi potrebami, obstaja tveganje, da tudi socialnopedagoški pristopi težijo k merjenju, oce- 
njevanju, testom in vprašalnikom in t. i. kategorizaciji otrok s posebnimi potrebami. Na ta način prispevajo $\mathrm{k}$ »maskiranju« družbenih problemov (Razpotnik, 2014). Družbeno se tako reducira, posameznik pa patologizira, kar vodi do tega, da intervencije pomoči niso usmerjene na družbene okoliščine oz. širši družbeni kontekst (Razpotnik, 2014). Vsekakor tudi na tem mestu ne smemo prezreti kontekstualne umeščenosti prevladujočih oblik pomoči, ki imajo podporo v sistemski ureditvi.

Kot preventivo »kontaminaciji« stroke s psihološko medicinskim diskurzom vidimo hermenevtični pristop ${ }^{3} \mathrm{k}$ diagnostiki (Rapuš Pavel, 1999; Halmi, 2005) in pomoč usmerjeno $\mathrm{v}$ življenjski prostor posameznika (Grunwald in Thiersch, 2008; Razpotnik, 2014), na podlagi katerih nato načrtujemo vzgojno pomoč. Za izpeljavo omenjenih pristopov in pomoči so bolj kot pri medicinsko psihološki obravnavi, kjer imamo natančno določene merske instrumente (testi, standardizirani vprašalniki, tabele, idr.), pomembne tudi sposobnosti, veščine in osebnostna naravnanost, kjer sproti odkrivamo, spoznavamo in se prilagajamo otroku/mladostniku, kar pomeni, da je zelo pomembna naravnanost na otroka/mladostnika, prilagodljivost razmišljanja in sposobnost avtentičnega vodenja. ${ }^{4} \mathrm{Za}$ razliko od medicinsko psihološkega modela, ki poudarja deficite otroka/mladostnika, socialnopedagoška diagnostika in interveniranje izhajata iz posameznika z osredotočenostjo na vire moči, varovalne dejavnike. S tovrstnimi pristopi socialni pedagog uresničuje inkluzivno paradigmo, kateri glavno "grožnjo« predstavlja medicinski model s kategorizacijo primanjkljajev (Črnak Meglič in Kobal Tomc, 2017).

Če je inkluzivna paradigma temelj vzgojno-izobraževalnega sistema kako to, da se socialnopedagoško razvrščanje in diagnostika, pri katerih je eden izmed glavnih ciljev zagotoviti podporno okolje otroku/mladostniku in na ta način uresničevati inkluzijo, ne postavlja ob bok medicinski, psihološki ali specialnopedagoški stroki?

3 Kjer se pri ocenjevanju otrokovega/mladostnikovega položaja na začetku ne oziramo na znanstveno prevladujoče kategorije in klasifikacije, ampak nas vodi vprašanje, »kako se nam nek dogodek prikazuje kot pojav, kako nam pride v zavest in kakšen način ravnanja terja." (Rapuš Pavel, 1999).

V primeru hermenevtičnega pristopa so edina oporna točka življenjska področja posameznika, ne zagotavlja pa nam, da bomo z vsemi otroki, mladostniki opravili enake intervjuje, enako hitro in da jih bomo lahko na podlagi informacij lahko razvrstili na kontinuumu OPP (Rapuš Pavel, 1999). Taka oblika raziskovanja nam omogoča, da bomo lahko načrtovali pomoč izhajajoč iz posameznika. 
Poleg vprašanja fleksibilnosti pomoči, kjer naj bi šlo za sodelovanje in usklajevanje pomoči različnih strokovnjakov, ki jo onemogočajo različne pristojnosti in medsebojna nasprotja med strokami (Grunwald in Thiersch, 20o8), enega od razlogov vidimo v ugotovitvi, da še vedno kategoriziramo OPP v skupine. To je dokaz, da smo v praksi še vedno na ravni integracije, katere cilj je prilagoditi otroka/mladostnika okolju in ne obratno (Globačnik, 2012). Zato je še toliko pomembneje, da si socialnopedagoški pristopi (vključno $\mathrm{z}$ diagnostiko) pridobijo veljavo.

Diagnostika socialne pedagogike izhaja iz posameznika in je zaradi tega izrazito kvalitativne narave. Njena tendenca, o kateri pišeta Krajnčan (2006) in Razpotnikova (2014, str. 56), je namreč v »delovanju »od spodaj navzgor« in temelji na izhajanju iz posameznika«, zato je ne moremo dovolj objektivizirati. V procesu diagnostike je socialni pedagog namreč osredotočen na vzpostavljanje odnosa, ki omogoča varnost, enakovrednost in posledično občutek sprejetosti. Kako dolgo bo otrok/mladostnik potreboval, da bo pripravljen vstopiti v odnos in se aktivno vključiti v reševanje lastnih težav, se ne da natančno predvideti. Časovna dimenzija je tako samo ena od »ovir« objektivizacije. Z vnosom pomembnosti pedagoškega odnosa (Krajnčan in Bajželj, 20o8) že v samem procesu diagnostike pa lahko potegnemo vzporednico s konceptom bistveno drugotnega stanja (Salecl, 1988) oz. z nekim temeljnim presežkom (Štefanc, 2012), ki pojasnjujeta zakaj socialnopedagoške diagnostike ni moč popolnoma objektivizirati. Tudi za pedagoški odnos bi lahko rekli, »da je neulovljiv presežek, torej vselej nekaj več od gole vsote empiričnih dejavnosti.« (Štefanc, 2012, str. 54). Če sem prištejmo še vse strukturne maksime $\mathrm{v}$ življenjski svet usmerjene socialne pedagogike (Grunwald in Thiersch, 2008), kot so prevencija, bližina vsakdanu, regionalizacija, integracija in participacija, ugotavljamo, da so argumenti v prid individualiziranemu in kvalitativnemu pristopu številni. Tudi če upoštevamo nevarnosti družbenega zlorabljanja socialne pedagogike, kot posledice napačno razumljenih (zgoraj naštetih) maksim (Grunwald in Thiersch, 2008).

$\mathrm{Z}$ idejo konstruktivizma smo na nek način bližje individualizaciji in diferenciaciji, torej tudi bližje na posameznika usmerjeni diagnostiki. Ali taka diagnostika še predvideva testiranja, ki temeljijo na definicijah normalnosti, povprečja oz. na kvantitativnih empiričnih objektivnih dejstvih? Ko v ospredje postavimo posameznika, lahko izhajajoč iz njega pod vprašaj postavimo družbeni konsenz o tem, kaj je povprečno, normalno, in na ta način izstopimo iz diskurza motnje, medicinskega diskurza, ki takega 
posameznika patologizira in $\mathrm{v}$ ospredje postavi zgolj njegovo individualno odgovornost (Razpotnik, 2014).

Naloga socialne pedagogike kot stroke in kot znanosti na področju diagnostike je $\mathrm{v}$ tem, da išče načine za pravno formalno uveljavitev inkluzivne paradigme in vztraja na ustvarjanju pogojev, ki bi v osnovni šoli omogočali čas in prostor za izvajanje socialnopedagoških pristopov diagnosticiranja in tudi interveniranja.' To lahko počne, če izobrazi in opolnomoči socialne pedagoge, ki (Grunwald in Thiersch, 2008):

- $\quad$ si znajo iskati in ustvarjati priložnosti za realizacijo in součinkovanje strukturnih maksim v življenjski svet usmerjene socialne pedagogike;

- ofenzivo in samozavestno profesionalno delujejo znotraj multidisciplinarnih strokovnih timov, kjer je sicer prisotna zaznamovanost $\mathrm{z}$ utrjenostjo različnih nosilcev, zakonskih pristojnosti ter $\mathrm{s}$ tem povezanih delovnih tradicij, ki pogosto merijo le na ohranjanje položajev.

\section{Vloga socialnega pedagoga pri zagotavljanju inkluzivnega} okolja za otroke in mladostnike $\mathrm{z}$ vedenjskimi, socialnimi in čustvenimi težavami ter preventivno delovanje

Glede na ugotovitve nekaterih avtorjev (Globačnik, 2012; Kobal Tomc idr., 2011; Opara idr., 2010; Vršnik Perše idr., 2016) so otroci/mladostniki z vedenjskimi in čustvenimi motnjami (po Kriterijih za opredelitev vrste in stopnje primanjkljajev, ovir oz. motenj otrok s posebnimi potrebami, 2015) v OŠ zelo maloštevilni (2,4-3,2 \%). Le-ti navajajo več razlogov, zaradi katerih prihaja do neustreznih usmeritev in obravnave te kategorije otrok, vsi pa poudarjajo, da spadajo med najbolj ranljive skupine OPP na celotni vertikali vzgoje in izobraževanja.

Koncept zgodnje obravnave, ki je zelo pomembna za zagotavljanje inkluzije na nacionalnem nivoju, je šele v uvajalni fazi. Prav tako pa se osnovnošolske prakse velikokrat osredotočajo le na terciarno preventivo in, kot smo že omenili, delujejo bolj integracijsko kot inkluzivno, zato je socialnopedagoško delovanje pravzaprav ključnega pomena za varovanje in zagotavljanje pravic otrok/mladostnikov z vedenjskimi, socialnimi in čustvenimi težavami, motnjami. 
Kljub temu, da je socialni pedagog v OŠ prisoten že več kot dvajset let, strokovnjaki še vedno ugotavljajo (Zaključki posveta Skupna odgovornost za sodelovanje za prezrte otroke $s$ posebnimi potrebami, 2015), da v šoli prevladujejo prepričanja strokovnih delavcev, da bi ti otroci/mladostniki zmogli, če bi hoteli, zato na osnovnošolskem nivoju niso deležni ustrezne pomoči in podpore. Ali to pomeni, da socialnopedagoška stroka v OŠ ne uspeva v svojem poslanstvu zaščite otrok/mladostnikov s težavami na vedenjskem, socialnem in čustvenem področju? Lahko bi rekli, da se dogaja to, kar smo že omenjali, socialni pedagogi so namesto emancipatorne vloge prevzeli vlogo stabilizatorja (in korektorja) obstoječih družbenih razmerij in ureditev (Zorc Maver, 2006). Kar pomeni, da imajo vse prepogosto vlogo zaščitnika otrok/mladostnikov, ki nimajo težav na vedenjskem, čustvenem in socialnem področju, pred tistimi, ki te težave imajo (še posebej eksternalizirano obliko). Namesto da bi torej delovali inkluzivno, vključevalno, sodelujejo pri izključevanju otrok z zgoraj omenjenimi težavami.

Čeprav obstajajo poskusi stroke, da bi bolj intenzivno sodelovala na zakonodajnem, torej pravno formalnem področju, le-ti niso bili uspešni (Razpotnik, 2014). Avtorica meni, da se je začelo celo nakazovati (predvsem v postopkih usmerjanja in izdajanja odločb za DSP), »da je v danih razmerah iz pragmatičnih razlogov morda celo bolje ostati pri stanju, kakršno je, saj se tako delu populacije, ki bi bil sicer lahko strokovno prezrt, znotraj danih finančnih shem zagotavlja dodatno strokovno pomoč. Strokovnjaki, ki to pomoč zagotavljajo, so morda res nezadovoljni zaradi omenjenega dometa lastnega strokovnega delovanja, vendar pa imajo vsaj službe, v okviru katerih lahko otrokom s tovrstnimi odločbami ponudijo vsaj nekaj, bi lahko karikirali.« (str. 61)

$\mathrm{Na}$ delo omenjenih strokovnih delavcev moramo torej pogledati celostno in kontekstualno ter na ta način razmišljati, kako bi lahko okrepili in opolnomočili te profesionalce, da bi v svojem delovnem okolju lahko vsaj delno dosegali (potrebne, strokovno utemeljene) spremembe v korist prezrti skupini otrok.

Menimo, da so za tako vlogo socialnega pedagoga zelo pomembne vse kompetence, ki jih navaja Krajnčan (2007a), še posebej pa tiste, s pomočjo katerih se lahko socialni pedagog strokovno pozicionira in avtonomno deluje v timu drugih strokovnih delavcev. ${ }^{6}$ Pri tem pa je pravzaprav nujno,

6 Tu bi še posebej izpostavili nekatere predmetno specifične socialnopedagoške kompetence (Krajnčan, 2007a, str. 11): "41. Razumevanje različnosti kot kvalitete, sprejemanje drugačnosti, odklonskosti in drugih kultur in subkultur; sposobnost ne- 
da aktivno sodeluje pri ustvarjanju sprejemajočega etosa vzgojne ustanove s pomočjo sodelavcev ter vodstva, ki ga podpirajo in se prav tako zavzemajo za vključujočo naravnanost OŠ. Pedagoški etos je "prepoznaven v pedagoškem odnosu, kulturi vedenja in povezovanja varovancev, vzgojiteljev in vodstva - in ne storilnostne naravnanosti in tržno usmerjene tekmovalnosti po sistemu zmage in poraza« (Gronenmeyer, v Krajnčan in Bajželj, 2008, str. 60).

Pomemben del tega pedagoškega etosa naj bi bilo tudi učinkovito preventivno delovanje, ki s svojo usmerjenost $\mathrm{v}$ življenjski svet mladim nudi pomoč in podporo (Thiersch, 1992). Avtor zelo poudarja opolnomočenje posameznikov za samopomoč in definiranje preventive v skladu s perspektivo »uporabnikov«.

V šolskem prostoru se še vedno najpogosteje pojavlja klasifikacija prevencije glede na časovno dimenzijo, ki izhaja iz medicine (Krajnčan, 2007b). ${ }^{7}$ Ko govorimo o vedenjskih, socialnih in čustvenih težavah je zgodnja oz. primarna preventiva najbolj učinkovita, saj lahko prepreči razvoj motenj. Zato bi bilo smiselno socialnim pedagogom v OŠ omogočiti, da bi lahko večino svojega delovnega časa posvetil primarni prevenciji, saj obstajajo primeri dobrih praks $\mathrm{v}$ obliki prostorov za neformalno druženje in ustvarjalno preživljanje prostega časa, doživljajskopedagoških projektov ipd. (Krajnčan, 2007b). Kljub omenjenim primerom pa prakse kažejo, da so socialni pedagogi (pa tudi drugi profili pomoči) večinoma prisotni v oblikah sekundarnih, še najbolj pa terciarnih preventivnih dejavnosti. Menimo, da k temu prispevajo opredelitve posameznih delovnih mest (socialnih pedagogov v OŠ), ki predvidevajo razlike v načinih, oblikah in metodah dela, $\mathrm{v}$ ciljih in pričakovanjih, delovnih pogojih in možnostih aktivne participacije pri oblikovanju šolskega etosa.

obsojajočega dela; 42. Empatičnost in komunikacijska odprtost; 43. Zavedanje in refleksija lastnih prispevkov v delu z ljudmi; sposobnost prevzeti odgovornost za lasten poklicni razvoj, motiviranost za supervizijske in intervizijske oblike dela; 44 . Ocena kakovosti in možnosti v posameznikovih socialnih mrežah (sorodstvo, sosedstvo, mreža institucij itd.); 45. Razumevanje institucionalnega delovanja, vpliva institucij na uporabnike, ozaveščanje lastne institucionalne vpetosti /.../; 47. Razumevanje in obvladovanje različnih oblik socialnopedagoškega dela /.../; 48. Strokovno delo, usmerjeno v življenjsko polje uporabnika; sposobnost delati v obstoječih socialnih pogojih /.../; 52. Sodelovalno delo v večdisciplinarnih strokovnih, projektnih, analitičnih, evalvacijskih skupinah /.../; 55. Analitično in raziskovalno delo na področju socialne pedagogike za potrebe razvoja prakse.«

$7 \quad$ Kar priča o tem, da je medicinski diskurz v osnovni šoli prisoten tudi na področju preventivnega delovanja. 


\section{Sklep}

Že pred dvajsetimi leti je Krajnčan (1997, str. 99) zapisal, da je socialni pedagog v OŠ potreben, »saj bo šola $\mathrm{z}$ večjim kadrovskim potencialom laže vzdrževala in spodbujala human in otroku prijeten ter koristen razvoj ter šolski vsakdan.»

Kritična refleksija trenutnega stanja nekaterih socialnopedagoških praks nam pokaže, da se je število socialnih pedagogov v OŠ sicer povečalo (med izvajalci DSP v OŠ je socialni pedagog zastopan v 5,4 odstotkih (Vršnik Perše idr., 2016)), vendar to ni bistveno prispevalo k humanizaciji šolskega vsakdana (Galimberti, 2015; Kobolt, 2010; Rutar, 2002). Eno od pomanjkljivosti vidimo $\mathrm{v}$ odsotnosti javnega prostora, kjer bi socialni pedagogi, kot javni intelektualci, avtonomno zagovarjali socialno in humano $\mathrm{v}$ socialnopedagoškem delu in raziskovali vzroke za pomanjkanje pravno formalne veljave. Zato jih je potrebno že $\mathrm{v}$ času študija opolnomočiti $\mathrm{z}$ vsebinami in kompetencami, ki spodbujajo kritično refleksijo obstoječih (socialnopedagoških) praks. Kar pomeni učenje in uporabo načinov spoprijemanja $\mathrm{z}$ anomalijami družbene in sistemske ureditve ${ }^{8}$ in na ta način okrepiti emancipatorno vlogo socialne pedagogike.

Osnovnošolski prostor je odslikava družbene realnosti (Apple, 2003), kjer prevladuje storilnostna naravnanost in individualizem s pripadajočo individualno odgovornostjo. Prav zato ima socialna pedagogika $\mathrm{z}$ ohranjanjem jasne vizije, s poudarjanjem pomembnosti pedagoškega odnosa in $\mathrm{s}$ svojimi oblikami, metodami in načini vzgojnega delovanja, ki ne izključujejo družbenega vidika in tudi pri diagnostiki izhajajo iz življenjskega prostora posameznika, njegovih virov moči, pomembno vlogo in nalogo. Skalar (1993, str. 42) jo opredeli kot "prispevek k humanizaciji odnosov v šoli, prispevek k boljši, sodobnejši šoli, prispevek k šoli, ki ne opravlja predvsem in samo izobraževalnih, pač pa tudi vzgojne naloge.«

Menimo, da si številni socialni pedagogi, pa tudi drugi strokovni delavci, želijo prispevati k humanizaciji in se zavedajo pomembnosti vzgojne vloge OŠ, vendar jih pogoji dela, ki so posledica tržne logike in organizacije vzgojno-izobraževalnega sistema in močno vplivajo na pedagoški etos in eros, onemogočajo. Tako se začetni entuziazem lahko spremeni v strah pred izgubo službe, pesimistično negodovanje, apatijo in celo izgorelost. Eno izmed ključnih vprašanj je torej, kako (tudi na sistemskem nivo-

8 Ti so po našem mnenju $\mathrm{v}$ znanstvenem raziskovanju in kritičnih teoretskih prispevkih, ki opozarjajo na take anomalije in vztrajajo na predlaganih spremembah. 
ju) poskrbeti za te entuziaste, jih opolnomočiti in povezati v kritično intelektualno sredino.

Če spremljamo sodobne trende, ki gredo v smeri marginalizacije, birokratizacije in polarizacije sodobnega sveta (Kobolt, 2015) ter povečevanja obsega dela in razvrednotenja nekaterih predvsem vzgojnih funkcij in vlog, bi lahko pomislili na to, da želi državni aparat čim bolj zaposliti, »izžeti« intelektualno delovno silo, kot protagonista sprememb, izboljšav. To počne $\mathrm{z}$ onemogočanjem dostopa do prostega časa za kritično razmišljanje, povezovanje, pisanje. Zato se nam zastavlja vprašanje, ali lahko emancipatorni potencial socialnopedagoškega diskurza in socialni pedagogi s svojimi organizacijskimi in vodstvenimi sposobnostmi prispevajo $\mathrm{k}$ temu, da bodo strokovni delavci v OŠ poskrbeli zase, za inkluzivni pedagoški etos tako, da si bodo priborili čas in prostor - zagotovili pogoje dela, ki bodo tak etos tudi omogočali?

Za take korake, utemeljene na socialni pravičnosti in inkluziji, sta potrebni zanesljiva delovna zavest in samozavest ter »delo na prepričljivih in diferenciranih oblikah predstavitve in dokumentacije, ki bodo podpirale in popisovale lasten $\mathrm{v}$ življenjski svet usmerjeni in strokovni pogled na življenjske razmere in pedagoško izvajanje, ne da bi podlegle stroki, tuji birokratizaciji in ekonomski instrumentalizaciji." (Grunwald in Thiersch, 2008, str. 24).

\section{Literatura}

Apple, M. W. (2003). The state and politics of knowledge. New York, NY; London: RoutledgeFalmer.

Bela knjiga o vzgoji in izobraževanju v Republiki Sloveniji 2011 (2011). Ljubljana: Zavod RS za šolstvo

Bouillet, D., in Uzelac, S. (2007). Osnove socijalne pedagogije. Zagreb: Školska knjiga.

Črnak Meglič, A., in Kobal Tomc, B. (2017). Položaj otrok v Sloveniji danes. Situacijska analiza. Ljubljana: Inštitut RS za socialno varstvo.

Dekleva, B., Kobolt, A., in Klemenčič Rozman, M. M. (2006). Analiza doseženih in zaželenih kompetenc študijskega programa Socialna pedagogika na Pedagoški fakulteti v Ljubljani. V S. Tancig in T. Devjak (ur.), Prispevki $k$ posodobitvi pedagoških študijskih programov (str. 150-169). Ljubljana: Pedagoška fakulteta.

Galimberti, U. (2015). Grozljivi gost: nihilizem in mladi. Ljubljana: Modrijan. 
Globačnik, B. (2012). Zgodnja obravnava. Ljubljana: Zavod Republike Slovenije za šolstvo.

Grunwald, K., in Thiersch, H. (2008). Koncept socialne pedagogike, usmerjene v življenjski svet - uvodna opažanja. V M. Krajnčan, D. Zorc Maver in B. Bajželj (ur.), Socialna pedagogika - med teorijo in prakso (str. 7-26). Ljubljana: Pedagoška fakulteta.

Grünfeld, T. (1997). Socialni pedagog v osnovni šoli. Socialna pedagogika, 1(4), 13-21.

Halmi, A. (2005). Strategije kvalitativnih istraživanja u primijenjenim društvenim znanostima. Jastrebarsko: Naklada Slap.

Juul, J., in Jensen, H. (2010). Od poslušnosti do odgovornosti. Radovljica: Didakta.

Kobal Tomc, B., Centrih, M., Zalokar, L., Švab, V., Bužan, V., Klanjšček, M., idr. (2011). Otroci in mladostniki s hudimi motnjami vedenja - analiza stanja. Ljubljana: Inštitut RS za socialno varstvo.

Kobolt, A. (2010). Izstopajoče vedenje, šola, družbeni kontekst. V A. Kobolt (ur.), Izstopajoče vedenje in pedagoški odzivi (str. 7-21). Ljubljana: Pedagoška fakulteta.

Kobolt, A. (2015). Svetovanje - kompetenca psihosocialnih poklicev. V A. Kobolt (ur.), Svetovanje v praksi (str. 9-22). Ljubljana: Pedagoška fakulteta.

Krajnčan, M. (1997). Šola in socialna pedagogika. Socialna pedagogika, 1(1), 91-100.

Krajnčan, M. (2006). Na pragu novega doma. Ljubljana: Pedagoška fakulteta.

Krajnčan, M. (2007a). Praktično pedagoško usposabljanje. Socialna pedagogika. Priročnik. Ljubljana: Pedagoška fakulteta.

Krajnčan, M. (2007b). Konceptualizacija preventivnih modelov v osnovni šoli. V T. Devjak, (ur.), Pravila in vzgojno delovanje šole (str. 119-141). Ljubljana: Pedagoška fakulteta.

Krajnčan, M., in Bajželj, B. (2008). Odnos - osnova za socialno pedagoško delo. V M. Krajnčan, M., Zorc Maver, D., in Bajželj, B. (ur.), Socialna pedagogika - med teorijo in prakso (str. 121-129). Ljubljana: Pedagoška fakulteta.

Laval, C. (2005). Šola ni podjetje. Neoliberalni napad na javno šolstvo. Ljubljana: Ministrstvo za kulturo RS in Javna agencija za raziskovalno dejavnost RS.

Müller, A. (1983). Integrative und integrierte Bewegungserziehung im Sozialisationsfeld Heimerziehung. Eine Fallstudie. V E. Knab (ur.), Heimerziehung - ein differenziertes Leistungsangebot (str. 79-106). Frankfurt/M: Peter Lang. 
Opara, B., Barle Lakota A., Globačnik, B., Kobal Grum, D., Košir, S., Macedoni Lukšič, M., idr. (2010). Analiza vzgoje in izobraževanja otrok s posebnimi potrebami v Sloveniji. Ljubljana: JRZ Pedagoški Inštitut.

Pravilnik o izobrazbi učiteljev in drugih strokovnih delavcev $v$ izobraževalnem programu osnovne šole. Uradni list RS, št. 109/11, 10/12, 92/12, 49/13 in 75/15. Pridobljeno 23. 12. 2016 s http://pisrs.si/Pis.web/ pregledPredpisa?id=PRAV10943

Rapuš Pavel, J. (1999). Hermenevtični pristop k socialnopedagoški diagnostiki. Socialna pedagogika, 3(1), 47-65.

Razpotnik, Š. (2014). Socialno v socialni pedagogiki. Sodobna pedagogika, 65 (3), 54-70.

Rutar, D. (2002). Učitelj kot intelektualec. Radovljica: Didakta.

Rutar, D. (2016). Možgani, učenci in šola. Pridobljeno s http://za-misli.si/ kolumne/dusan-rutar/3205-mozgani-ucenci-in-sola

Rutar, D. (2017). Zadnji intelektualci. Pridobljeno s http://za-misli.si/kolumne/ dusan-rutar/3209-zadnji-intelektualci

Salecl, R. (1988). Vzgoja kot »bistveno drugotno stanje«. Problemi: revija za kulturo in družbena vprašanja, 11, 119-125.

Skalar, V. (1993). Socialni pedagog v osnovni šoli. Iskanja, 13, 36-43.

Štefanc, D. (2012). Kompetence v kurikularnem načrtovanju splošnega izobraževanja. Ljubljana: Znanstvena založba Filozofske fakultete.

Štremfel, U., Barle Lakota, A., in Polak, A. (2014). Učna (ne)uspešnost: pogledi, pristopi, izzivi. Ljubljana: Pedagoški inštitut.

Thiersch, H. (1992). Lebensweltorientierte Soziale Arbeit. Weinheim: Juventa Verlag.

Valenčič Zuljan, M. (2001). Modeli in načela učiteljevega profesionalnega razvoja. Sodobna pedagogika, 52(2), 122-141.

Vec, T. (2011). Moteče vedenje: ozadja in osnovni dejavniki, ki nanj vplivajo. Socialna pedagogika, 15(2), 125-152.

Vernooji, M. A. (1995). Training needs of teachers working with emotionally disturbed children. V M. Pitter in P. Dausit (ur.), Teacher education for special needs in Europe (str. 61-74). London, New York, NY: Cassell.

Vidmar, M., in Kerman, K. (2016). The development of teacher's relational competence scale: Structural validity and reliability. Pridobljeno s http://www.pei.si/UserFilesUpload/file/digitalna_knjiznica/SP/2016/SP_ XXVII_2016_1-2/Solsko\%2opolje,\%2OXXVII,\%20vol\%201-2,\%202016.pdf 
Vovk Ornik, N. (ur.) (2015). Kriteriji za opredelitev vrste in stopnje primanjkljajev, ovir oz. motenj otrok s posebnimi potrebami. Ljubljana: ZRSŠ.

Vršnik Perše, T., Schmidt Krajnc, M., Čagran, B., Košir, K., Hmelak, M., Bratina, T., idr. (2016). Evalvacija različnih oblik dodatne strokovne pomoči, ki je otrokom dodeljena $v$ skladu $z$ Zakonom o usmerjanju otrok $s$ posebnimi potrebami. Nacionalna evalvacijska študija: končno poročilo. Maribor: Pedagoška fakulteta.

Zaključki posveta »Skupna odgovornost za sodelovanje za prezrte otroke s posebnimi potrebami« (2015). Pridobljeno s http://www.drustvo-srp.si/ images/DS_Zaklju\%C4\%8Dki.pdf

Zakon o osnovni šoli (1996). Uradni list RS, št 12/1996, Z dne, 29. 2. 1996. Pridobljeno 23. 12. 2016 s http://www.uradni-list.si/1/objava. jsp?urlid $=199612 \&$ stevilka $=570$

Zakon o osnovni šoli (2006). Uradni list RS, št. 81/2006, $\mathrm{z}$ dne 31. 7. 2006. Pridobljeno 23. 12. $2016 \mathrm{~s}$ http: //www.uradni-list.si/1/objava. jsp?urlid $=200681 \&$ stevilka $=3535$

Zorc Maver, D. (2006). Socialna pedagogika v družbi negotovosti. V M. Sande, B. Dekleva, A. Kobolt, Š. Razpotnik in D. Zorc Maver (ur.), Socialna pedagogika: Izbrani koncepti stroke (str. 23-35). Ljubljana: Pedagoška fakulteta. 



\title{
Nameščanje in diskurz o (ne)ustreznosti vzgojne pomoči otrokom/mladostnikom s čustvenimi in vedenjskimi težavami in/ali motnjami v vzgojnih zavodih
}

\author{
Mateja Marovič \\ OŠ Veržej - enota DOM, \\ Univerza na Primorskem, Pedagoška fakulteta
}

\section{Uvod}

Oddaja ${ }^{\mathrm{I}}$ otroka ali mladostnika v vzgojni zavod (v nadaljevanju: VZ) predstavlja poseg $\mathrm{v}$ družino, ki običajno povzroči številne, čustveno negativne reakcije staršev in otroka. Pri starših občutke krivde zaradi lastne vzgoj-

1 Otroka/mladostnika je v VZ mogoče namestiti po:

1. določbah Zakona o usmerjanju otrok s posebnimi potrebami (v nadaljevanju: ZUOPP-1) (2011) (37., 38. in 39 člen);

2. določbah 119., 120. in 121. členih Zakona o zakonski zvezi in družinskih razmerjih (v nadaljevanju: ZZZDR-UPB1) (2004). Ukrep oddaje predstavlja posamezniku hud rez $\mathrm{v}$ njegovo integriteto, saj pomeni posebno omejitev njegove prostosti (Caharijaz Ferme, 2013). Zato zakon v nadaljevanju posebej določa, da mora ukrep prenehati takoj, ko prenehajo razlogi, zaradi katerih je bil le-ta izrečen. Traja lahko največ tri leta. Izjemoma sme center za socialno delo (v nadaljevanju: CSD) na podlagi mnenja zavoda podaljšati ukrep oddaje, vendar samo zaradi nujnosti oz. dokler obstajajo razlogi. V praksi, kot ugotavlja že N. Caharijaz Ferme (2013), pride to največkrat v poštev, kadar otrok/mladostnik obiskuje šolo in želi le-to zaključiti. Posameznik, ki dopolni osemnajst let, sme ostati v zavodu le v primeru, da v to privoli;

3. 183. členu Zakona o izvrševanju kazenskih sankcij (v nadaljevanju: ZIKS-1-UPB1) (2006). Vzgojni ukrep oddaje v VZ se izvršuje v skladu s predpisi, ki urejajo usmerjanje mladostnikov s posebnimi potrebami (v nadaljevanju: PP). Za izvedbo vzgojnega ukrepa, ki ga v kazenskem postopku izreče sodišče, skrbi CSD. Minister pristojen za šolstvo določi VZ, v katerih se izvaja vzgojni ukrep oddaje v VZ za posamezne kategorije mladoletnikov. Vzgojni ukrep oddaje, ki ga v kazenskem postopku izreče sodišče, v Sloveniji izvaja en osnovnošolski (OŠ Veržej - enota Dom), en osnovnošolski ter hkrati srednješolski zavod (Vzgojni zavod Planina) ter trije srednješolski zavodi (Vzgojni zavod Slivnica pri Mariboru, Vzgojno izobraževalni zavod Višnja Gora in Zavod za vzgojo in izobraževanje Logatec) (Sklep o določitvi vzgojnih zavodov, v ka- 
ne neuspešnosti, pri otroku/mladostniku jezo, strah pred neznanim (zavodom) ter občutke nemoči. Zanemariti ne gre niti dejstva, da »otroci in mladostniki, ki so vedenjsko "problematični«, praviloma zase ne iščejo pomoči« (Svetin Jakopič, 2005, str. 400; prim. Krajnčan, 2006), temveč jo nasprotno največkrat odklanjajo. Poleg tega je v laični javnosti še vedno prisotno mišljenje, »da je oddaja v zavod za otroka kazen, za družino pa sramota.« (Vzgojni program, 2004, str. 21). Vsi ti dejavniki lahko povzročijo številne odpore - pri starših in posamezniku, ki se v zavod namešča ter nepotrebne odkrite in/ali prikrite ovire $\mathrm{v}$ zavodskih prizadevanjih, da bi s strokovno pomočjo pomagali posamezniku in njegovi družini (Vzgojni program, 2004, str. 21).

\section{Diskurz - nameščanje}

Vprašanja Kdaj oddati otroka/mladostnika v vzgojni zavod?, Kateri so odločilni dejavniki, ki do namestitve pripeljejo? in Ali ter koliko je eliminacija in posledično vključitev $v$ specifično obliko izvendružinske institucionalne pomoči za določenega posameznika primerna? predstavljajo dilemo, s katero se pri svojem delu vsakodnevno srečujemo strokovni delavci v VZ. Dodatno dilemo predstavlja védenje, da »lahko intervencije, ki skušajo resocializirati s segregacijo (v nekaterih primerih, op. a.), povzročijo več škode kot koristi (npr. problemi stigmatizacije, kriminalne kariere).« (Krajnčan, 2006, str. 263).

Če izhajamo iz teorije in prakse nameščanja, lahko v grobem trdimo, da so prvotni razlogi za usmeritev oz. oddajo ${ }^{2}$ otrok in mladostnikov v VZ večinoma njihove vedenjske in/ali čustvene težave in/ali motnje, ki v posameznikovem domačem okolju eskalirajo s tolikšno intenziteto, da jim predvsem starši ter učitelji niso več kos. Navedenemu sledi še dikcija »v naj-

terih se izvaja vzgojni ukrep oddaje v vzgojni zavod za posamezne kategorije mladoletnikov, 2013).

CSD v vseh omenjenih primerih spremlja izvajanje ukrepa, v prvih dveh pa pri odločanju in oddaji neposredno sodeluje (prim. Kosmač, 2007).

2 Čeprav je v obremenilnih življenjskih dogodkih ob stresnih in konfliktnih situacijah ter življenjskih krizah lahko težavna večina odraščajoče mladine (Skalar, 2003), postanejo naslovniki zavodske vzgoje predvsem tisi posamezniki, ki - zaradi spleta različnih, neugodnih okoliščin primarnega ter sekundarnega okolja, slabe družbe, socialno-ekonomske disfunkcionalnosti družine, posredno tudi družbenih mehanizmov izločanja ipd. - ne zmorejo zadostiti potrebam kontroverznih predstav posameznih, vladajočih socialnih skupin v družbi (Kobolt, 2011). 
večjo korist otroka «³, iz katere smo pri oddaji, na podlagi pravno zavezujočih se dokumentov, dolžni izhajati.

Kot ugotavljamo v praksi, ${ }^{4}$ vzroki za napotitev največkrat temeljijo v genezi oz. koeksistenci heterogenih med seboj so-vplivajočih se dejavnikov, ki jih lahko strnemo v naslednje sklope:

- neugodno družinsko ozadje (ločitve, bolezni, smrt, zanemarjenost; preobremenjenost, nemoč, psihične težave staršev; različne vrste zasvojenosti; konfliktnost roditeljev/partnerjev; nasilje, spolne in druge zlorabe ipd.), $\mathrm{v}$ povezavi s socialno-ekonomsko-družbeno depriviligiranostjo (brezposelnost, nizki socialni status, neprimerni bivalni prostori, nezmožnost nudenja osnovnih življenjskih pogojev/dobrin, neizobraženost/nizka izobraženost) ter odsotnostjo različnih vrst kapitala;

- $\quad$ težave $v$ šoli (odklanjanje šole in učnega dela, izostajanje od pou$\mathrm{ka}$, verbalno/fizično nasilje nad sošolci in/ali strokovnimi delavci, neupoštevanje šolskih pravil ipd.);

- neugoden vpliv okolja (primarnega/sekundarnega);

- $\quad$ pripadnost odklonskim vrstniškim skupinam (negativni vplivi vrstnikov, vandalizem);

- prisotnost oz. konzumiranje različnih nedovoljenih substanc (alkohol, trde/mehke droge) ter

- $\quad k o e k s i s t e n c a$ naštetih dejavnikov (medsebojno učinkovanje bioloških, psiholoških, socialno-ekonomskih, okoljskih ter drugih dejavnikov).

Največjo težo izvora, ki posledično pripelje do namestitve posameznika v VZ, avtorji (Bürger, v Krajnčan, 2006; Trade, v Krajnčan, 2006; Rapuš Pavel in Kobolt, 2008; Skalar, 2000; idr.) pripisujejo primarni celici otrokovega razvoja, družini, v povezavi z zgoraj naštetimi dejavniki.

3 Bolj pravilo kot izjema se izkaže tudi dejstvo, da so namestitve v VZ, kot že Krajnčan (2006), reakcije socialne kontrole na oblike odklonskega, v družbi nezaželenega vedenja. Potreba po nastanitvi je tako večkrat v nasprotju s subjektivnimi željami otrok/mladostnikov, dokončno zakoličena z definicijami in odločitvami CSD ali sodišč (Krajnčan, 2006).

4 Pri ugotovitvah izhajamo iz diagnostične dokumentacije zbrane v osebnih mapah otrok/mladostnikov Doma Veržej. Na tem mestu izpostavljena dokumentacija zajema uradne dokumente zbrane pred prihodom otroka/mladostnika v Dom. In sicer: odločbo o usmeritvi, osnovnošolsko dokumentacijo, morebitno diagnostično oceno pedopsihiatra ter relevantne druge dokumente in poročila, iz katerih je razvidno, zakaj se posameznik v Dom namešča. 
Trade (v Krajnčan, 2006) tako iz poročil o vzrokih za napotitev otrok/ mladostnikov v VZ izpostavi: neugodne oz. »težke« družinske razmere, nastale zaradi različnih vzrokov (stanovanjska stiska, brezposelnost, nizki socialni status ipd.); nadproporcionalna prizadetost otrok/mladostnikov etničnih manjšin, enostarševskih, dopolnjenih in nepopolnih družin; prav tako pa ugotavlja, da je bil velik odstotek nameščenih posameznikov priča psihičnemu kot tudi fizičnemu nasilju v družini. Med vzroki za napotitev avtor navaja še starševske težave povezane $\mathrm{z}$ odvisnostjo od alkohola, mamil oziroma drugih, nedovoljenih substanc.

Bürger (v Krajnčan, 2006) izhajajoč iz empiričnih raziskav, verjetnost, da posameznik postane naslovnik zavodske vzgoje, v veliki meri povezuje s pripadnostjo socialno prikrajšanim slojem prebivalstva, katerim botruje dokaj neproporcionalen delež nizke formalne izobrazbe, čemer posledično sledi zaposlenost $\mathrm{v}$ poklicih na nižjih položajih ali sploh nimajo zaposlitev, le-ti pa prevladujoče pripadajo spodnjim skupinam pri dohodkih in/ali so odvisni od socialne pomoči. Podobno Skalar (2000), ki ugotavlja, da izhajajo mladostniki, ki so oddani v VZ, najpogosteje iz družin, kjer imajo starši nizko izobrazbeno stopnjo, nizke osebne dohodke ter skromne stanovanjske pogoje. Večinoma so zaposleni kot nekvalificirani ali polkvalificirani delavci ali pa so nezaposleni (Skalar, 200o).

Izhajajoč iz disocialnega vedenjskega sindroma kot kriterije za nameščanje v VZ Bečaj (1989) izpostavi: nizko delovno učinkovitost, pomanjkanje aktivnih interesov, delovnih navad, stikov z normalnimi vrstniki, pozitivnega čustvenega stika $z$ odraslimi ter izločenost iz socialnega okolja. ${ }^{6}$ Avtor ugotavlja, da »bolj kot je opisan disocialni vedenjski sindrom očiten, manjša je možnost, da se v otrokovem okolju uspešno ukrepa«, kar pomeni tudi, »da je začaran krog med mladostnikom in okoljem sklenjen do take mere, da okolje motnjo s svojimi reakcijami že samo po sebi vzdržuje« (str. 20). Zato predstavlja omenjen sindrom pomemben signal, da je otroka/mladostnika smiselno »izključiti« iz primarnega socialnega okolja (str. 20).

Podobno dikcijo v kvalitativni študiji navajata J. Rapuš Pavel in A. Kobolt (2008). Ugotavljata, da »družine, iz katerih so otroci oddani v razne oblike zavodske vzgoje, ne zmorejo zadostiti otrokovim razvojnim potrebam. Roditelji so v starševskih vlogah negotovi, neorganizirani, nestabilni, preobremenjeni z lastnimi partnerskimi, čustvenimi, delovnimi, socialnimi in materialnimi problemi.« (str. 99)

6 Kot najpogosteje navajano simptomatiko osnovnošolske populacije, ki botruje namestitvi v VZ, Bečaj (2003, str. 13) izpostavi še: verbalno in fizično agresivnost, trpinčenje, neupoštevanje pravil, upiranje, laganje, izostajanje od pouka, slabo vodljivost, nemirnost, neuspešnost v šoli, lažja kazniva dejanja, zlorabo psihoaktivnih sredstev ipd. 
$\mathrm{CSD}^{7}$ - ki pri oddaji otrok/mladostnikov v določen VZ igrajo odločilno vlogo - kot najpogostejše razloge za namestitev navajajo učne težave povezane $\mathrm{z}$ vedenjskimi težavami, nemočjo staršev ter socialno ogroženostjo (http://www.csd-lj-siska.si/dejavnosti/dejavnosti.asp?DID=85036312). Dekleva (1989) v raziskavi oddaje posameznikov v VZ razloge, ki jih strokovni delavci na CSD najpogosteje navajajo pri oddaji, strne v: odklonsko vedenje, ki kaže na vzgojno zanemarjanje; kazniva dejanja; ogroženost otroka. Dodaja še posameznikovo željo po odhodu v zavod, ki pa je - izhajajoč iz prakse nameščanja Doma Veržej - bolj izjema kot pravilo. V zaključnem poročilu Posvet: Sodelovanje med centri za socialno delo in (vzgojnimi) zavodi od ogleda do odpusta pri obravnavi otrok/mladostnikov (2011) udeleženci kot najpogostejše vzroke namestitve navajajo: vzgojno nemoč staršev, težavno družinsko situacijo, vzgojno zanemarjenost, ogroženost otroka, zlorabe otrok, beganje otrok, zlorabo drog in alkohola (eksperimentiranje), neprimerno družbo vrstnikov, alkoholizem staršev, izostajanje otrok iz šole in/ali šolsko neuspešnost.

Sinteza teoretičnih in empiričnih ugotovitev izpostavljenih avtorjev nakazuje na večplastnost in kompleksnost rizičnih dejavnikov, ki jih je pri oddaji posameznika v VZ mogoče zaznati, ter številnost med seboj zelo prepletenih dejavnikov, na katerih namestitev temelji. Zaradi tega je ugotovitev Krajnčana (2009), da je pri oddaji v VZ potrebno izhajati iz sestave oz. sistema razmer vseh dejavnikov, ki do odločitve o namestitvi pripeljejo, še kako upravičena. Oddaja otrok/mladostnikov v VZ predstavlja namreč

$7 \quad$ V izsledkih Krajnčanove raziskave, Analiza kriterijev oddaje otrok in mladostnikov v vzgojne zavode (2003, str. 146-147), so merila strokovnih delavcev na CSD, ki odločilno vplivajo na oddajo otroka/mladostnika v VZ, naslednja:

- namestitev otroka v VZ, ko so izčrpane vse druge možnosti (ambulantna pomoč, vse oblike znotraj socialne mreže, vse oblike ponujene v domačem okolju);

- zaradi težkih družinskih razmer (doma ni možnosti za zdrav razvoj otroka, manj spodbudno okolje, vzgojni stil staršev, vzgojna nemoč staršev, fizično in psihično nasilje ter zlorabe);

- zaradi šolske neuspešnosti (odklanjanje šole, odklonilnost do učiteljev, neopravičeno izostajanje, neupoštevanje šolskih norm);

- čustvena/vedenjska težavnost otroka/mladostnika (odklonske oblike vedenja, osebnostne značilnosti, kazniva dejanja, zloraba drog ipd.);

onemogočanje normalnega/zdravega razvoja otroka/mladostnika (v sedanjem socialnem okolju ni osebe, ki bi lahko mladostniku to omogočala (odsotnost odrasle referenčne osebe, op. a.));

- primernost zavoda (zagotovitev konstantnosti okolja, možnost strokovne obravnave, ustreznost zavoda glede na pripravljenost otroka/mladostnika in staršev idr.); - klinično psihološko mnenje ali izvid, mnenje komisije za razvrščanje, predhodne informacije pedopsihiatrične obravnave ipd. 
veliko bolj subtilno področje, kot se na prvi pogled mogoče zdi. Zaradi kompleksnosti ter težko opredeljive interakcije med vzročnimi dejavniki in pojavnimi oblikami ČVT/M bi »težko našli enotne kriterije za oddajo v vzgojne zavode.« (Krajnčan, 2006, str. 168). Svojo hipotezo avtor utemelji z že omenjeno raziskavo Analiza kriterijev oddaje otrok in mladostnikov $v$ vzgojne zavode (Krajnčan, 2003), ki je pokazala, da v slovenskem prostoru nimamo enotnih kriterijev oddajanja otrok in mladostnikov v VZ. Leti, kot ugotavlja tudi S. Kosmač (2007), še vedno predstavljajo nevralgično točko, ${ }^{8}$ saj kar polovica timov, ki odločajo o oddaji otroka/mladostnika v vzgojno institucijo, nima izdelanih meril, ${ }^{9}$ po katerih odločajo, ali je otrok/ mladostnik potreben vzgoje v zavodu (prim. Krajnčan, 2006).

Kot lahko sklepamo iz navedenega in čemur smo priča tudi v praksi, so načini odločanja CSD za oddajo otroka/mladostnika $\mathrm{v}$ posamezen $\mathrm{VZ}$ zelo neenotni, kriteriji nerazpoznavni, končna odločitev pa je, kot že Krajnčan (2006, str. 170), »bolj ali manj prepuščena strokovnim delavcem, ki imajo o vzgojnih zavodih zelo različna mnenja pa tudi različne izkušnje. ${ }^{10}$

Če torej skušamo odgovoriti na v uvodu zastavljeno vprašanje Kateri so odločilni dejavniki, ki do namestitve pripeljejo?, ugotovimo, da je pri odgovoru potrebno izhajati iz sinteze dognanj multidisciplinarnega pristo$\mathrm{pa}^{\text {II }}$ vseh v postopek vključenih akterjev: staršev; pristojnega CSD; šole, ki

8 Tako med CSD - kot že Krajnčan (2003; prim. Krajnčan, 2006) in kot kažejo tudi ugotovitve iz prakse - obstajajo signifikantne razlike že v samem kriteriju nameščanja.

9 Med merili za oddajo v VZ so svetovalni delavci najpogosteje navajali predvsem odgovore, kot so: ko je zanj škodljivo bivanje v družini, šolska neuspešnost in vedenjske težave (Krajnčan, 2003). Kot primer navajamo še raziskavo Bürgerja (v Krajnčan, 2006, str. 169), v kateri so ugotovili, da »otroka, ki bi ga center za socialno delo številka 1 takoj oddal v vzgojni zavod, center za socialno delo številka 2 nikoli ne bi.«.

10 Navedeno se potrdi kot upravičeno tudi v zaključkih že omenjenega Posveta: Sodelovanje med centri za socialno delo in (vzgojnimi) zavodi od ogleda do odpusta pri obravnavi otrok/mladostnikov (2011), v katerem so aktivno sodelovali predstavniki CSD ter predstavniki VZ, ki so s problematiko nameščanja otrok/mladostnikov s ČVT/M najbolj neposredno povezani. Le-ti v ugotovitvah prav tako izpostavijo dilemo različne prakse CSD, ki obstaja pred namestitvijo otroka/mladostnika v določen VZ, kar potrjuje tudi trenutno aktualen diskurz prakse nameščanja.

11 Multidisciplinarni pristop nameščanja mora poleg podrobne anamneze posameznikovega funkcioniranja - ki naj temelji na izčrpnem opisu njegovega vedenja ter okoliščin, v katerih je le-to predvidoma prisotno - izhajati še iz ko-eksistence kriterijev, vzrokov ter dejavnikov, ki jih posamezni avtorji za oddajo v VZ izpostavljajo kot ključne. Ponovno je potrebno opozoriti, »da je ob odločanju za izločitev iz domačega okolja potrebna celostna ocena, saj nas vrsta, ne le že citiranih, avtorjev opozarja, 
jo posameznik obiskuje; morebitnih zdravstvenih služb, ki otroka/mladostnika obravnavajo, idr. Se pravi celotne mikro in makro sfere posameznikovega okolja, v katero je le-ta vključen. Še posebej, ker vemo, da »na socialnopedagoškem področju med vzroki in posledicami ne potekajo enoznačni odnosi.« (Svetin Jakopič, 2005, str. 394).

Vprašanje Koliko je eliminacija in posledično vključitev v specifično obliko izvendružinske institucionalne pomoči za določenega posameznika primerna? nam predstavlja iztočnico, na katero bomo skušali odgovoriti v naslednjem poglavju.

\section{(Ne)ustreznost vzgojne pomoči v vzgojnih zavodih}

Strokovni delavci $\mathrm{V} \mathrm{VZ}^{12}$ se $\mathrm{v}$ zadnjem času srečujemo $\mathrm{z}$ vse večjim delom posameznikov s ČVT/M, katerih narava je zelo kompleksna. ${ }^{13}$ Kompleksnost težav izhaja iz kombiniranih, težkih oblik vedenjske problematike, ki v nekaterih primerih segajo že globoko v področje pedopsihiatrije in širše psihiatrije (prim. Zalokar, 2013).

Kot je razvidno iz raziskave Otroci in mladostniki s hudimi motnjami vedenja: Analiza stanja ${ }^{\mathrm{I4}}$ (Kobal Tomc idr., 2011) gre za populacijo otrok/ mladostnikov, za katero se $\mathrm{v}$ zadnjih letih vse pogosteje ugotavlja, da obstaja brez primernega ter ustreznega tretmana, saj VZ »pogosto niso ustrezno opremljeni za njihovo obravnavo, niti po kadrovski niti po namestit-

da nobena specifična deviacija ni sama po sebi dovolj zanesljiv znak, da gre mladostnik zanesljivo v delikvenco.« (Bečaj, 1989, str. 20). Procesi zaznavanja, definiranja ter proces odločitve (Krajnčan, 2006) so tako odločilne komponente, ki do namestitve pripeljejo.

12 Z omenjeno dilemo se srečujejo tudi CSD (Kobal Tomc idr., 2011; Anzeljc Bratina idr., 2013). Ker sami izhajamo iz polja delovanja VZ, se bomo v nadaljevanju osredotočili na slednje.

13 Podobno Skalar že leta 1998. Problematika pa se je v zadnjem času, zaradi prisotnosti izrazito segregacijske funkcije neoliberalističnega družbenega sistema, še okrepila.

14 Raziskava, izvedena v okviru Inštituta Republike Slovenije za socialno varstvo, analizira problematiko usmerjanja in nameščanja otrok/mladostnikov s hudimi motnjami vedenja v sisteme skrbi v Sloveniji. V pričujoči raziskavi, v kateri so sodelovali Vzgojno-izobraževalni zavodi (VIZ)/Mladinski domovi (MD), CSD in Center za usposabljanje, delo in varstvo (CUDV), gre za analizo, predstavitev oz. posnetek stanja in ne za poglobljeno raziskavo. Vendar pa lahko opravljena analiza, kot pravijo avtorji, »služi kot dobro in verodostojno izhodišče za nadaljnje raziskovanje in spremljanje problematike na bolj poglobljen ter individualiziran način«, se pravi za individualno spremljanje članov ciljne populacije v daljšem časovnem obdobju (Kobal Tomc idr., 2011, str. 54). 
veni plati «. ${ }^{\text {Is }}$ (Kobal Tomc idr., 2011, str. 51; prim. Anzeljc Bratina idr., 2013; Kobolt, 2015; Krajnčan in Šoln Vrbinc, 2015). Težave se pojavijo predvsem takrat, ko ugotovimo, da je otrok/mladostnik presegel okvire VZ in da mu le-ta s svojimi socialnopedagoškimi prijemi - zaradi spleta različnih dejavnikov (nesodelovanja posameznika; različnih oblik agresij, nasilja do sebe in/ali do drugih; konzumiranja nedovoljenih substanc; zavodsko okolje je zanj bolj ogrožajoče kot okolje doma idr.) - ne more več pomagati. ${ }^{16}$

Razlogov, zakaj smo pri obravnavi najtežjih oblik vedenjske problematike neuspešni, je več. S. Svetin Jakopič (2005) navaja naslednje:

"Mladostnik je vpet v množico začaranih krogov, ki vedenjske motnje utrjujejo in jih delajo trdovratne; vedenjska problematika se sčasoma začne vzdrževati sama od sebe ne glede na prvotne vzroke formiranja; mladostnik in njegovi starši navadno niso motivirani za prejemanje pomoči (temveč le-to, predvsem starejši posamezniki, zavračajo op. a.), pogosto se pri njih pojavljajo odpor, jeza, strah do obravnav; ovire pa so tudi na strani strokovnih delavcev.« (str. 391-392)

Ovire, ki se nemalokrat kažejo v neustreznosti namestitve, izhajajo tudi iz strokovne »neopremljenosti« VZ za določeno vrsto specifične problematike kompleksnih težav, ki so pri posamezniku prisotne.

Najbolj objektiven vpogled $v$ navedeno problematiko, ki se nanaša na neustreznost namestitve $\mathrm{v}$ določen $\mathrm{VZ}$ ter aktualno stanje $\mathrm{v}$ slovenskem prostoru, je mogoče razbrati iz že omenjene raziskave Otroci in mladostniki s hudimi motnjami vedenja: Analiza stanja (2011), katere ugotovitve navajamo v nadaljevanju. Po mnenju strokovnih delavcev VZ, VIZ in MD (v nadaljevanju: $z a v o d o v^{17}$ ) so za tretjino otrok/mladostnikov omenjenih institucij le-ti menili, da namestitev pri njih ni ustrezna predvsem zaradi naslednjih razlogov:

15 Čeprav skuša domska vzgoja, kljub svojim funkcijsko določenim institucionalnim omejitvam, realizirati tako varnost kakor privlačnost, pa se "tako diferencirana struktura raznih oblik pomoči vse bolj kaže kot nezadostna.« (Grunwald in Thiersch, 2008, str. 18).

16 V zadnjih petih letih se skoraj v vsaki vzgojni skupini najdeta eden do dva otroka/ mladostnika, za katera ugotavljamo, da k nam pravzaprav ne sodijo.

17 Gre za prikaz stanja v 8 od 10 slovenskih VZ (Otroci in mladostniki s hudimi motnjami vedenja: Analiza stanja, 2011). 
- agresije, nasilja in konfliktov s strani otrok/mladostnikov. ${ }^{18}$ Strokovni delavci teh institucij navajajo, da se srečujejo s fizičnimi napadi na osebje, fizičnim obračunavanjem med sostanovalci. Otroci/mladostniki namerno uničujejo zavodski inventar (pohištvo, opremo), kršijo zavodska pravila, v instituciji in njeni okolici izvršujejo kazniva dejanja ter prekrške. Ti posamezniki s svojim delinkventnim in/ali destruktivnim vedenjem vplivajo na ostale mladostnike, tako da »/.../ kadar govorimo o notranji agresiji, samopoškodbah, se lahko v skupini pojavi trend samopoškodovanja ali pa dejanja tveganja, ko mladoletni spremljajo poizkuse suicida ali celo smrti« (str. 72);

- nesodelovanja otroka/mladostnika: namestitev ne more potekati po načrtu, če posameznik namestitvi nasprotuje, je nemotiviran in/ali se upira avtoriteti. Strokovni delavci zavodov navajajo, da imajo posamezniki poleg tega še hud odpor do šole, zaradi česar tudi velikokrat pobegnejo iz zavoda. Tako v nekem zavodu opažajo, da »je 95 \% mladostnikov, ki so nameščeni v našem zavodu, popolnoma nemotiviranih za bivanje $v$ zavodu in namestitev sprejemajo kot kazen « (str. 73);

- $\quad$ specifične problematike otroka/mladostnika, ko v zavodu ne morejo nuditi vseh oblik pomoči, ki bi jih posameznik potreboval. ${ }^{19}$ Kot slabost zavodi navajajo dejstvo, da pred sprejemom v večini primerov ni opravljena pedopsihiatrična diagnoza. Poleg tega si želijo, »da bi imeli več možnosti (tudi zakonodajne) pri reševanju posameznih primerov, ki bi dopuščali ustvarjalne, drugačne rešitve, primerne za posamezne primere« (str. 73). Pri tem primeru so nekatere zavodske institucije izpostavile, da na CSD včasih slabše prepoznavajo posameznikove potrebe in je zaradi tega lahko le-ta napoten v neustrezen zavod; ${ }^{\circ}$

V zavodih (VZ, VIZ, MD) je bilo v letu 2010 vključenih 113 otrok in mladostnikov, ki so nasilni do sebe in/ali do drugih, v začetku leta 2011 (od januarja do marca) pa je bilo takih posameznikov 81 (Otroci in mladostniki s hudimi motnjami vedenja: Analiza stanja, 2011).

Podobno rezultati raziskave Krajnčan in P. Šoln Vrbinc (2015), v kateri anketiranci izpostavljajo pomanjkanje ustrezne pomoči otrokom/mladostnikom s kombiniranimi in psihiatričnimi motnjami ter da »za določene motnje ni ustreznih ustanov in ustrezno izobraženega kadra« ipd. (str. 29). 
- prisotnosti nedovoljenih substanc, v okviru česar zavodi poudarjajo, da namestitev v takih primerih ni primerna, saj ne morejo izvajati Individualiziranega vzgojnega načrta (v nadaljevanju: IVN), če posameznik uživa nedovoljene substance;

- nesodelovanja staršev: dogaja se, da starši »s svojim nefunkcioniranjem onemogočajo vzgojno pedagoški proces« (str. 73; podobno Anzeljc Bratina idr., 2013).

Strokovni delavci zavodov so v omenjeni a nalizi izpostavili še problem:

- $\quad$ zakonodaje, za katero pravijo:

"Področna šolska zakonodaja ovira oz. celo povsem blokira razvoj specifičnih programov: "Ocenjujemo, da danes za tako populacijo otrok in mladostnikov $v$ RS ni ustrezno poskrbljeno, iz česar sledi nameščanje po sistemu poskusov in zmot, ki je praviloma prepozno in tako vnaprej obsojeno na neuspeh". In "Po sedaj veljavni šolski zakonodaji zahtevamo od naših otrok/mladostnikov, da aktivno sodelujejo pri pouku (do šest ur dnevno ${ }^{21}$ ) in zadostijo vsaj minimalnim standardom znanja, če želijo napredovati v višji razred. Učna uspešnost je preveč poudarjena, zanemarja pa se njihovo duševno stanje, stiska zaradi travmatskih izkušenj in učenje socialnih veščin «. Poleg tega so izpostavili počasnost in postopnost sodišč ter to, da posamezniki čedalje bolj zlorabljajo trenutno neizdelan pristop in sistem« (str. 78);

- zagotavljanja varnosti: $:^{22}$

Kljub številni medikamentozni »terapiji« nekaterih posameznikov. Naj kot argument k zgornji trditvi navedemo še stanje v Domu Veržej. V našem zavodu je na medikamentozni »terapiji« 22 od skupno 39 otrok/mladostnikov. Eden od teh prejema 4 različne medikamentozne terapije, štirje otroci/mladostniki 3 in pet posameznikov po 2 različni medikamentozni terapiji. Stanje se nanaša na mesec april šolskega leta 2015/2016. Podobno rezultati raziskave Med preteklostjo in prihodnostjo zavodske vzgoje (Krajnčan in Šoln Vrbinc, 2015), kjer avtorja ugotavljata, da je bilo po poizvedbah Ministrstva za izobraževanje, znanost in šport v letu 2012 psihiatrično obravnavanih 41,2 \% zavodske populacije, kar pomeni, da je psihiatrično obravnavanih skoraj polovica otrok.

22 Izhajajoč iz prakse se nam zdi še posebej pomembno izpostaviti prav problem zagotavljanja varnosti vsem udeležencem vzgojno-izobraževalnega procesa v VZ, saj predstavlja le-ta predpogoj uspešnemu uresničevanju vzgojnih ciljev, ki jim pri svojem delu moramo slediti. Za boljši oris v navedeno problematiko na tem mestu izpostavljamo le nekatere, katerih realizacija - ob predpostavki prisotnosti posameznika, ki v celoti zavrača zavodski tretma (ogroža sebe in/ali ostale) - ni uresničljiva. Ne pri slednjih in ne pri posameznikih, ki zavodski tretma sprejemajo. In sicer: Ure- 
"Nekaj zavodov je poudarilo, da je osebje ob fizičnem napadu oz. ogroženosti popolnoma nemočno, saj ni mogoče zagotoviti pravice po varnosti. Problem obravnave se pojavi takrat, ko zavodi s svojimi pedagoškimi ukrepi ne morejo več zagotavljati varnosti otrok/ mladostnikov in zaustaviti nasilnega posameznika, da bi tako zaščitili njega pred samim sabo in druge pred njim: »Tu se srečata pravica posameznika do pomoči in šolanja ter pravica drugih otrok do varnosti - katera je pomembnejša?» (str. 78; podobno Anzeljc Bratina idr., 2013)

$\mathrm{Na}$ tem mestu velja $\mathrm{v}$ razmislek izpostaviti še dilemo nameščanja romskih in priseljenskih otrok. Razlog neustreznosti namestitve je pri romski populaciji najverjetneje iskati $\mathrm{v}$ raznovrstnih in kontradiktornih zahtevah kulturno pogojene različnosti okolja, ki v nekaterih primeri posledično botruje izločitvi posameznika iz njegove primarne etnične skupnosti. Pri navedenem izhajamo iz ugotovitev M. Marovič (2010), ki se $\mathrm{z}$ omenjeno problematiko ukvarja $\mathrm{v}$ članku Romi, socialni kapital ter dileme glede nameščanja romskih otrok v vzgojne zavode. Avtorica, na podlagi kronologije dogodkov izpostavljenega primera iz prakse, ugotavlja, da otrok - zaradi nasprotovanja zavodskemu tretmanu večinskih pripadnikov njegove romske skupnosti - doživlja dodatne travme, ki izhajajo iz védenja, da »nikamor in nikomur več ne pripada« (str. 267). Možnosti uspešne obravnave takega posameznika v VZ so zaradi navedenega precej okrnjene, kasnejša (re)integracija $\mathrm{v}$ domače okolje pa - ob védenju, »da so vezi med posameznikom in njegovim okoljem tiste, ki pogojujejo stopnjo njegove socialne vključenosti« (Cattel, v Zrim Martinjak, 2006, str. 49) - prav tako vprašljiva. Vendar pa romska populacija, kot vemo, v Sloveniji ni homogena, saj se Romi med seboj razlikujejo »tako po pripravljenosti na integracijo v sloven-

sničevanje preventivnih socialno-varstvenih in zdravstvenih ciljev, kjer za uresničevanje le-teh zagotavljamo: ustrezne bivalne pogoje, ki omogočajo posameznikovo zasebnost; pogoje za učenje in interesno udejstvovanje; ugodno psihosocialno klimo; preprečujemo vplive razvojno ogrožajočih, neugodnih dejavnikov na posameznikov razvoj iz njegovega matičnega okolja in v ustanovi, ki izvaja vzgojni program (Vzgojni program, 2004). Zgoraj navedeni cilji v situacijah, ko posameznik s skupino svojih privržencev prevzame "nadzor« nad VZ, niso realizirani. Predvsem v zavodih zaprtega tipa - ki so v tem kontekstu mišljeni kot ustanove, kjer pod eno streho biva velika skupina posameznikov - povzročajo taki upori dodatne psihične stiske »normalni« zavodski populaciji, ki naj bi se jim ravno z namestitvijo v VZ ter s tem izločitvijo iz domačega, "neprimernega oz. disfunkcionalnega« okolja, izognili. Dimenzija okolja ter odnosa, ki med obojimi omenjenimi posamezniki prihaja v ospredje, v neidealnih razmerah, še dodatno utrjuje že prisotne težave ali pa generira nove. 
sko družbo kot tudi po že doseženi stopnji integracije« (Hrženjak, 2002, str. 88), zaradi česar na podlagi izpostavljenega primera ${ }^{23}$ dilem (ne)ustreznosti nameščanja romske populacije ne moremo posploševati na vse pripadnike omenjene etnične skupnosti. Razlog neustreznosti namestitve priseljenskih otrok pa je vsekakor (ne)poznavanje slovenskega jezika in kulturne razlike, ki so pomemben dejavnik pri doseganju šolskega (ne)uspeha priseljenskih otrok in mladostnikov. Sinjur (2010) zato še posebej izpostavlja in poudarja, da je eden od izzivov, s katerimi se mora soočiti vzgoja in izobraževanje, tudi strategija vključevanja priseljenskih učencev.

Zanemariti ne gre niti pogostih premestitev ${ }^{24}$ iz enega $\mathrm{v}$ drugi VZ z eliminacijo posameznikov, ki veljajo za posebej problematične - ki večinoma služijo vzpostavitvi reda v določeni ustanovi. Tako se v VZ - kot že Krajnčan (2012, str. 117) in kot izhajajoč iz prakse ugotavljamo sami - »izmenjujejo faze rigidnega upoštevanja pravil in faze anomije«, zaradi česar plačujejo otroci/mladostniki, za katere v našem sistemu ni ustrezne pomoči, (pre)visoko ceno. ${ }^{25}$

Če pri vsem omenjenem izhajamo še iz polja delovanja socialnopedagoške doktrine, se tukaj njena vloga postavlja pod vprašaj. Za interpretacijo si sposodimo metaforo "figovega lista «, o katerem v intervjuju z A. Kobolt (2001) govori A. Frommann. Z metaforo »figovega lista« želi A. Frommann,

23 V zadnjem desetletju smo bili v Domu Veržej priča trem podobnim primerom, kjer je primarna romska etnična skupnost - zaradi nestrinjanja večinske skupnosti z namestitvijo in posledično tretmanom v VZ - otroka iz svoje sredine izločila.

Tveganje za otroka, ki ga večkrat premeščajo iz VZ v drugo podobno ali enako ustanovo, narašča, saj so, kot že Krajnčan (2006, str. 67), ob tem "posebej ogrožene osebnostne značilnosti, kot so obvladovanje okolja, stopnja aktivnosti in optimizma.« (Najbolj občutljiva starost pri namestitvi je med 11. in 14. letom.) Avtor nadaljuje s čimer se sami popolnoma strinjamo -, da so ti posamezniki praviloma »igračka pristojnih in ustanov, ki navadno nimajo pravice soodločanja o njihovi usodi in preseljevanju iz ustanove v ustanovo « (str. 67). Osebnostne težave, ki se izražajo v naučeni nemoči in izgubi kontrole nad lastnim življenjem, so za te posameznike značilne (Krajnčan, 2006).

25 Rezultati raziskave, Otroci in mladostniki s hudimi motnjami vedenja: Analiza stanja (2011), ravno tako kažejo, da imajo CSD težave z nameščanjem teh otrok/ mladostnikov $\mathrm{v}$ institucije - saj posebej specializiranih institucij pri nas ni (z izjemo VZ Planina) -, zato ti posamezniki v vmesnem obdobju pogosto ostajajo doma (v okviru matične oz. primarne družine), ob čemer je pomembno tudi dejstvo, da beležijo kar nekaj primerov, ko so taki otroci/mladostniki nameščeni v psihiatrične bolnišnice, celo na zaprte oddelke za odrasle (prim. Zalokar, 2013). Slednje (nameščeni v psihiatrične bolnišnice na zaprte oddelke za odrasle), kot tudi vse ostale na tem mestu navedene ugotovitve, lahko na podlagi večletnega dela $s$ tovrstno populacijo (na žalost) tudi sami potrdimo. 
tako Š. Razpotnik (2006), pojasniti delovanje, ki ga od stroke pričakuje širša družba. In sicer naj »sproti odpravlja in večini skriva težave in »družbene probleme«, da ti širši družbi ne bi bili v napoto« (str. 32). Če pri tem izhajamo iz Krajnčanove (2010) družbene determinante oddaje otroka/ mladostnika v VZ - ki po mišljenju večinske družbe temelji na »nevarnosti«, ki je pri zgoraj omenjeni specifično težavni populaciji v ospredju - lahko na nek način tudi pri obravnavi posameznikov, ki zaradi kompleksnosti problematike ne »sodijo « v noben družbeni sistem in v nobeno institucijo (pa v njih vseeno ostajajo), izhajamo iz omenjene metafore »figovega lista Socialna pedagogika ter $\mathrm{z}$ njo povezane tudi vse druge stroke, ki so pristojne za obravnavo zgoraj omenjenih posameznikov, se v tem primeru, tako Š. Razpotnik (2006, str. 32), odrekajo »svoji ofenzivnosti in zanikajo dinamično naravo družbe s podreditvijo nosilcem moči«. Zato ne preseneča dejstvo, da je Ministrstvo za izobraževanje, znanost in šport na eni strani sicer dovzetno za težave, s katerimi se pri omenjeni populaciji v VZ srečujemo, vendar pa je (skoraj) z vsakega njihovega dopisa med vrsticami razbrati tudi negativno konotacijo, ${ }^{26}$ da smo zavodi za tako problematiko otrok/mladostnikov usposobljeni ter s tem namenom tudi ustanovljeni.

"Tako morajo zavodi, ki se z obširnim seznamom izključitvenih kriterijev sprejema (na primer uživanje mamil, psihotične motnje ...) otepajo težavnih nalog vzgoje, v situacijah, kjer ponudba prostih zavodskih mest presega povpraševanje in jim grozi, da bodo morali zavod zapreti, močno skrčiti katalog svojih sprejemnih kriterijev. ${ }^{27}$ Zato sprejemajo tudi take, ki jim zaradi koncepta dela ali zaradi drugih razlogov niso kos." (Krajnčan, 2012, str. 188)

S tem pa se dela škoda tako tistim, ki so sprejeti, kot tistim, ki so v ustanovi že nameščeni. Na tem mestu odpove vsa strokovnost, kot tudi rek »v najboljše dobro otroka«, prav tako se zanemarijo otrokove, velikokrat (pre) pogosto opevane pravice.

In ker je ena izmed nalog socialnega pedagoga ter s tem tudi njegova odgovornost do širšega okolja in javnosti, da »od družbe zahteva ustrezne pogoje za optimalno življenje svojih uporabnikov« ter »podpira poli-

26 Le-ta je še posebej opazna pri ekstremnih primerih zavodskih posameznikov, ki so (zaradi različnih razlogov) popolnoma prerasli okvirje vseh trenutno obstoječih zavodskih institucij v Sloveniji. Izjema je, kot že rečeno VZ Planina, ki pa ima na žalost premajhno namestitveno kapaciteto.

27 Opozoriti velja, da se kriteriji sprejema med VZ, MD ter stanovanjskimi skupinami (SS) v praksi zelo razlikujejo. 
tiko in zakone, ki po njegovi profesionalni presoji prispevajo $\mathrm{k}$ dobrobiti njegovih uporabnikov in odklanja takšne, ki niso v skladu z njegovimi profesionalnimi prepričanji« (Etični kodeks delavcev na področju socialne pedagogike, 2006, str. 196), je naša naloga tudi, da na tem mestu še posebej opozorimo, da je zadnji čas za sistemske spremembe. ${ }^{28} "$ Treba je poiskati ustrezne rešitve med ministrstvom za socialo in družino, ${ }^{29}$ ministrstvom za šolstvo, ${ }^{30}$ ministrstvom za pravosodje, ministrstvom za notranje zadeve ter ministrstvom za zdravstvo ${ }^{31}$ in temu primerno prilagoditi zakonodajo ter uskladiti mrežo pomoči. «2 $^{32}$ (str. 79)

\section{Sklep}

Na podlagi navedenega zaključujemo, da je obravnavana problematika preveč kompleksna in obširna, da bi na tem mestu lahko odgovorili na vsa zastavljena vprašanja, ki se nam ob večplastnosti vzgojno-izobraževalne institucionalne (ne)pomoči (pri obravnavi najtežjih oblik vedenjske problematike) otrok/mladostnikov zastavljajo.

Navedeno stanje kaže na neustreznost sistemsko urejene državne skrbi ${ }^{33}$ (izhajajoč iz področja šolstva, socialnega varstva, zdravstva, zara-

28 Nujnost sistemskih rešitev, ki bodo bolj individualizirane ter prilagojene posameznikovim individualnim potrebam, predvsem tistim (kot že rečeno), katerim »tradicionalna « zavodska vzgoja ne more pomagati, nakazuje tudi raziskava dejanskega stanja Otroci in mladostniki s hudimi motnjami vedenja: Analiza stanja (2011), ki prav tako ugotavlja, da je obstoječi sistem tog, nefleksibilen ter do omenjene populacije neprijazen.

29 Danes: Ministrstvo za delo, družino in enake možnosti RS.

30 Danes: Ministrstvo za izobraževanje, znanost in šport RS.

31 Danes: Ministrstvo za zdravje RS.

32 Povezovanje, dopolnjevanje ter usklajenost med službami in resorji, ki so vpete $\mathrm{v}$ procese nudenja pomoči otrokom/mladostnikom s PP, ter nadgradnjo in dopolnitev obstoječih mrež pomoči, ki naj bi jo sestavljali predstavniki različnih ministrstev, izpostavlja tudi Program za otroke in mladino 2006-2016 (2006). V sklopu vzgojnoizobraževalne politike le-ta poudarja zagotavljanje enakih možnosti za vzgojo in izobraževanje, med drugim tudi z zagotavljanjem sistemskih pogojev za "uspešnejše vključevanje (predvsem otrok iz socialno ranljivih skupin) v sistem vzgoje in izobraževanja.« (str. 13)

33 Izpostaviti velja, da nameščanje v VZ, ki spadajo pod okrilje Ministrstva za izobraževanje, znanost in šport, vodijo CSD, ki pa spadajo pod Ministrstvo za delo, družino, socialne zadeve in enake možnosti. Navedeno je razlog - kot ugotavljamo tudi v praksi -, da se to področje toliko težje ureja (prim. Krajnčan, 2010). Ne nazadnje se razhajanja različnih strok v percepciji razumevanja zavodske vzgoje izražajo tudi tako ugotovitev raziskave Moči, izzivi, vizije vzgojnih zavodov (Kobolt, 2015) - v nerealnih pričakovanjih drugih ustanov, ki z VZ sodelujejo. »Izražena so tudi občutja, 
di pogoste delinkventnosti tudi policije in pravosodja), ki je pri določenem delu omenjene populacije primanjkuje. ${ }^{34}$ Manko v smislu družbene in strokovne (so)odgovornosti države do ustrezne pomoči posameznikom najtežjih oblik vedenjske problematike, je mogoče iskati tudi v dejstvu, da država vse do danes "nima nikakršnega organa, ${ }^{35} \mathrm{ki}$ bi vodil in bil odgovoren za področje vzgoje in izobraževanja otrok s posebnimi potrebami« (Opara idr., 2010, str. 13), med katere sodi tudi zavodska populacija. Zato - pri intervencijah in individualizirani, predvsem $\mathrm{v}$ posameznika usmerjeni pomoči, ki bi je morali (izhajajoč iz otrokovih pravic) biti deležni tudi otroci/mladostniki, ki v »tradicionalne« okvire zavodske vzgoje ne sodijo - ne preseneča, »da ni ustreznega povezovanja med strokami v ožjem smislu in prakso kot tudi ne ustrezne družbene in oblastne skrbi za to področje.«

Dokumentov (tudi predlogov ${ }^{36}$ ), ki na nacionalni ravni kličejo $\mathrm{k}$ posodobitvi ter vzpostavitvi ustreznejše mreže trenutno obstoječe pomoči v

da jih želijo druge stroke poučevati in morda iz svojih perspektiv ne zmorejo razumeti kompleksnosti vzgojnega položaja in dela«. (str. 120) Navedeno - kot v vzgojno-izobraževalno-zdravstveni interakciji na podlagi izkušenj z nekaterimi institucijami (v tem primeru predvsem z pedopsihiatrijo) ugotavljamo sami - implicirajo tudi teoretično deskriptivne ugotovitve Krajnčana in P. Šoln Vrbinc (2015): »V procesu sodelovanja s psihiatrijo Gintzel in Schone (1990) (tudi Feyerabend, 1995, str. 158; Köttigen, 1998, str. 69) opozarjata, da je vse preveč prisotno pomanjkanje dialoga, hierarhija medicinske usmerjenosti in procesov moči, izhajajočih iz tega. Tako ima že družbeno definirano višji položaj psihiatrija nad vzgojo in diagnoza psihiatra nad oceno socialnega pedagoga.« (str. 18)

34 »Gre za kompleksno in zahtevno problematiko, izvajalci vzgojno-izobraževalnih ter zdravstvenih programov pa za obravnavo te skupine otrok in mladostnikov niso ustrezno opremljeni, ne $\mathrm{z}$ vidika prostora in kadra ne $\mathrm{z}$ vidika doktrine dela, zato ti otroci in mladostniki ostajajo brez ustrezne obravnave." (Kobal Tomc idr., 2011; podobno Svetin Jakopič, 2005; Zalokar, 2013 idr.).

35 »Poudariti je potrebno, da v Sloveniji vse do danes - kljub večletnim apelom prakse po nujnosti tovrstnega organa, op. a. - na nacionalni ravni ne obstaja nek enotni organ za področje vzgoje in izobraževanja otrok s posebnimi potrebami, kot je to praksa v večini članic EU (posebni oddelki v okviru ministrstev, agencije ...)« (Opara idr., 2010, str. 13), kot tudi ne organ, ki bi posebej urejal področje otrok/mladostnikov s ČVT/M (prim. Kobal Tomc idr., 2011; Anzeljc Bratina idr., 2013).

36 Strinjamo se s predlogi avtorjev že omenjenega dokumenta Otroci in mladostniki s hudimi motnjami vedenja: Analiza stanja (2011), ki za izboljšanje obstoječe ureditve navajajo široko paleto izboljšav. Nanašajo se na reorganizacijo ter posodobitev polja zavodske vzgoje z vsemi pristojnimi resorji (šolstvo, sociala, zdravstvo, policija, sodstvo), ki morajo v vseh pogledih izhajati iz največje koristi otroka. V grobem le-ti zajemajo: vzpostavitev sistema učinkovitega zgodnjega odkrivanja težav obravnavanih otrok/mladostnikov; posodobitev sistemske ureditve; razvijanje specializiranih programov; okvire izobraževanja; zagotovitev specializiranega in usposobljenega kadra; zagotovitev institucij bolj zaprtega tipa za tiste posameznike, 
polju zavodske vzgoje - ki bi ustrezali tako tistim, katerim namestitev v VZ ustreza in je zadostna, kakor tistim, za katere »tradicionalni« zavodski okvir ni primeren, znotraj področja institucionalne obravnave otrok/ mladostnikov s ČVT/M -, v Slovenskem vzgojno-izobraževalnem prostoru ne primanjkuje. Vendar pa le-ti, žal, še vedno ostajajo zgolj na deklarativni ravni. Trenutno aktualen diskurz (ne)ustreznosti nameščanja je tako še vedno prepuščen iznajdljivosti posamezne zavodske arene ter praktikov, ki, tako B. Müller (2008, str. 125; prim. Krajnčan, 2010), delajo z uporabniki in so prisiljeni tudi hitro ukrepati, »ne da bi dovolj vedeli in ne da bi natančno razumeli posameznikove potrebe«, kar pa ne zadosti potrebi po nujno potrebnih rešitvah, ki bi jih aktualni naslovniki zavodske vzgoje potrebovali. ${ }^{37}$

Zato je naša naloga, da poiščemo »rešitve tudi za tiste otroke, za katere v obstoječem sistemu ni zagotovljene ustrezne obravnave « $^{38}$ (Anzeljc Bratina idr., 2013, str. 23). Moč in sredstva »je potrebno usmeriti v skupnostne oblike obravnave, ki se nahajajo blizu doma, šole in družine, zagotoviti pomoč družinam in s tem zmanjšati proces institucionalizacije« (Kobal Tomc idr., 2011, str. 96). In ne nazadnje, treba je uvideti, da so »zavodski otroci« - tudi tisti, pri katerih je odpovedala vsa strokovna pomoč - »navadni otroci, ki imajo enake želje in potrebe kot vrstniki, zaradi niza neugodnih okoliščin in $s$ tem povezanih socialnih in zdravstvenih težav pa jih zelo težko uresničujejo« (Krajnčan, Miklavžin in Zorc Maver, 2010, str. 96).

ki odklanjajo pomoč in s svojim vedenjem ogrožajo sebe in druge; pospeševanje raziskovanja in spodbujanje pilotnih projektov (povzeto po Otroci in mladostniki s hudimi motnjami vedenja: Analiza stanja, 2011, str. 81, 92-93, 95).

Ali če parafraziramo Krajnčana (2012, str. 127): „Vse ovire, ki se kažejo kot medresorske neusklajenosti, zakonska togost, nejasna nacionalna socialna politika in še kaj bi se našlo, so preslab izgovor, da ne bi sledili potrebam otrok, ki glasno trkajo na vrata.«Brez kontinuiranega povezovanja vseh zgoraj naštetih dejavnikov ni mogoče oblikovati jasne vizije in koncepta, ki bi izhajala iz koristi in za korist otroka/ mladostnika, zaradi česar je že tako marginalizirana skupina otrok/mladostnikov s ČVT/M še dodatno postavljena na stranski tir.

38 Kam bo šel razvoj slovenske zavodske vzgoje ter s tem povezana (ne)ustreznost zavodske mreže pomoči v prihodnje - ob vse večjih apelih zavodskih delavcev, ki se srečujemo $\mathrm{z}$ vedno večjo populacijo posameznikov, ki jim z uveljavljenimi socialnopedagoškimi prijemi zaradi akutne individualne patologije ne moremo več zagotoviti ustreznih pogojev, pogojev, ki bi omogočali optimalen razvoj posameznika - je težko predvideti. Zagotovo pa nam dezinstitucionalizacijski procesi, vključno z drugimi teoretskimi usmeritvami, ki so namenjene profesionalizaciji in humanizaciji izvendružinske družinske vzgoje, kažejo, »da nismo nikoli dovolj humanizirali pomoči otrokom v vzgojnih zavodih, da jih ne bi mogli še bolj.« (Krajnčan, 2012, str. 126) 


\section{Literatura}

Anzeljc Bratina, M., Brdar Tomažinčič, R., Cafuta, I. J., Dečman, M., Leva, J., Petrovec Zajc, J., ... Velič, I. (2013). Posvet: Sodelovanje med centri za socialno delo in (vzgojnimi) zavodi od ogleda do odpusta pri obravnavi otrok/mladostnikov. Kaljenje. Bliten skupnosti CSD Slovenije, 12, 7-12.

Bečaj, J. (1989). Oddaja otrok in mladostnikov v vzgojne zavode. Kriteriji za oddajo v vzgojni zavod. Ptički brez gnezda, 13(27), 7-29.

Bečaj, J. (2003). Disocialnost pri otrocih in mladostnikih. Slovenska pediatri$j a, 10(1), 12-27$.

Caharijaz Ferme, N. (2013). Postopek za zaščito otroka na centru za socialno delo. Kaljenje. Bilten skupnosti CSD Slovenije,12, 24-31.

Dekleva, B. (1989). Oddaja otrok in mladostnikov v vzgojne zavode. Razlike med občinami ter stališča delavcev centrov za socialno delo. Ptički brez gnezda, 28(13), 58-74.

Etnični kodeks delavcev na področju socialne pedagogike. (2006). V M. Sande, B. Dekleva, A. Kobolt, Š. Razpotnik in D. Zorc Maver (ur.), Socialna pedagogika: izbrani koncepti stroke (str. 191-196). Ljubljana: Pedagoška fakulteta.

Grunwald, K., in Thiersch, H. (2008). Koncept socialne pedagogike, usmerjene v življenjski svet - uvodna opažanja. V M. Krajnčan, D. Zorc Maver in B. Bajželj (ur.), Socialna pedagogika - med teorijo in prakso (str. 7-26). Ljubljana: Pedagoška fakulteta.

Hrženjak, M. (2002). Zgodovinski, kulturni in družbeni vidik vključevanja romskih otrok v slovenske vrtce. Socialna pedagogika, 6(1), 81-93.

Kobal Tomc, B., Centrih, M., Zalokar, L., Švab, V., Bužan, V., Klanjšček, M., in Pavlič, S. (2011). Otroci in mladostniki s hudimi motnjami vedenja Analiza stanja. Ljubljana: Inštitut Republike Slovenije za socialno varstvo.

Kobolt, A. (2001). Intervju z Anne Frommann: Socialna pedagogika v funkciji »figovega lista«. Socialna pedagogika, 5(3), 375-386.

Kobolt, A. (2011). Razumevanje in odzivanje na čustvene in vedenjske težave. V O. Poljšak Škraban (ur.), Razumevanje in odzivanje na problematiko otrok s težavami v socialni integraciji. Socialna pedagogika, tematska števil$k a, 15(2), 153-173$.

Kobolt, A. (2015). Opredelitev konteksta in ciljev raziskovanja - Oris stanja in vizija razvoja vzgojnih ustanov. V A. Kobolt (ur.), Moči, izzivi, vizije vzgojnih zavodov (str. 37-46). Ljubljana: Pedagoška fakulteta. 
Kosmač, S. (2007). (Ne)ustreznost kriterijev za opredeljevanje otrok s čustveni$\mathrm{mi}$ in vedenjskimi motnjami. Socialna pedagogika, 11(3), 361-383.

Krajnčan, M. (2003). Analiza kriterijev oddaje otrok in mladostnikov v vzgojne zavode (Doktorska disertacija). Univerza v Ljubljani, Pedagoška fakulteta, Ljubljana.

Krajnčan, M. (2006). Na pragu novega doma: Oddaja otrok v vzgojni zavod. Ljubljana: Pedagoška fakulteta.

Krajnčan, M. (2009). Behavioural and emotional disorders of children and adolescents in Slovenian juvenile educational institutions. Socialna pedagogika, 13(2), 147-174.

Krajnčan, M. (2010). Otroci in mladostniki v vzgojnih zavodih, stanovanjskih skupinah in mladinskih domovih. V M. Krajnčan in P. Miklavžin (ur.), Zdravje mladostnikovs čustvenimi in vedenjskimi težavami (str. 34-55). Ljubljana: Ministrstvo za zdravje.

Krajnčan, M. (2012). Dezinstitucionalizacija na področju vzgojnih zavodov. V A. Rafaelič in V. Flaker (ur.), Iz-hod: iz totalnih ustanov med ljudi. Časopis za kritiko znanosti, domišljijo in novo antropologijo, tematska številka, 39(250), 116-127.

Krajnčan, M., in Šoln Vrbinc, P. (2015). Med preteklostjo in prihodnostjo zavodske vzgoje. V A. Kobolt (ur.), Moči, izzivi, vizije vzgojnih zavodov (str. 11-33). Ljubljana: Pedagoška fakulteta.

Krajnčan, M., Miklavžin, P., in Zorc Maver, D. (2010). Oris zdravstvene problematike (namen raziskovanja). V M. Krajnčan in P. Miklavžin (ur.), Zdravje mladostnikov s čustvenimi in vedenjskimi težavami (str. 57-99). Ljubljana: Ministrstvo za zdravje.

Marovič, M. (2010). Romi, socialni kapital ter dileme glede nameščanja romskih otrok v vzgojne zavode. Socialna pedagogika, 14(2), 247-270.

Müller, B. (2008). O odnosu med terapijo, pedagogiko in socialnim delom ravnanje s časom, kot profesionalna naloga. Socialna pedagogika, 12(2), 124-144.

Opara, B., Barle, A., Globačnik, B., Kobal Grum, D., Košir, S., Macedoni Lukšič, M., ... Vršnik Perše, T. (2010). Analiza vzgoje in izobraževanja otrok s posebnimi potrebami. Ljubljana: JRZ Pedagoški inštitut.

Program za otroke in mladino 2006-2016. (2006). Ministrstvo za delo, družino in socialne zadeve. Pridobljeno s http://www.varuh-rs.si/fileadmin/ user_upload/pdf/konferenca_o_participaciji_otrok 
Rapuš Pavelj, J., in Kobolt, A. (2008). Alkoholizem v družini in doživljanja mladostnic, ki bivajo v vzgojnem zavodu. V M. Krajnčan, D. Zorc Maver in B. Bajželj (ur.), Socialna pedagogika med teorijo in prakso (str. 97-120). Ljubljana: Pedagoška fakulteta.

Razpotnik, Š. (2006). Izziv socialni pedagogiki: biti glasnica družbenega obrobja. V M. Sande, B. Dekleva, A. Kobolt, Š. Razpotnik in D. Zorc Maver (ur.), Socialna pedagogika: izbrani koncepti stroke (str. 23-35). Ljubljana: Pedagoška fakulteta.

Sinjur, A. (2010). Učenci z imigrantskim ozadjem - politike in praksa učenja maternega jezika učencev imigrantov v nekaterih državah EU. Educa, 19(3-4), 59-69.

Skalar, V. (1998). Vzgojne ustanove na prehodu v postindustrijsko družbo. Socialna pedagogika, 2(2), 5-17.

Skalar, V. (2000). Vzgojni zavodi v funkciji preprečevanja delinkventnosti in disocialnosti pri otrocih in mladostnikih. V A. Šelih (ur.), Prestopniško in odklonsko vedenje mladih (str. 151-161). Ljubljana: Bonex.

Skalar, V. (2003). Socialna integracija otrok z vedenjskimi in čustvenimi težavami v osnovni šoli. Šolsko svetovalno delo, 3-4(8), 8-14.

Sklep o določitvi vzgojnih zavodov, v katerih se izvaja vzgojni ukrep oddaje v vzgojni zavod za posamezne kategorije mladoletnikov. (2013). Ministrstvo za izobraževanje, znanost in šport. Številka: 6034-22/2013/2. Datum: 8. 4. 2013.

Svetin Jakopič, S. (2005). Obravnava otrok in mladostnikov z vedenjskimi motnjami na centru za socialno delo: Pomoč ali prisila. Socialna pedagogika, 9(4), 391-422.

Vzgojni program. (2004). Pridobljeno s http://www.mizs.gov.si/fileadmin/mizs. gov.si/pageuploads/podrocje/posebne_potrebe/programi/Vzgojni_program.pdf

Zakon o izvrševanju kazenskih sankcij (ZIKS-1-UPB1) (2006). Uradni list RS, št. 110/2006 z dne 26. 10. 2006. Pridobljeno s http://www.uradni-list.si/1/objava.jsp?sop=2006-01-4665

Zakonousmerjanjuotroksposebnimipotrebami(ZUOPP-1)(2011). Uradnilist RS 58/2011 z dne 22. 7. 2011. Pridobljeno s http://www.zrss.si/pdf/050911123118_ zakon_o_usmerjanju_otrok_s_posebnimi_potrebami_22072011.pdf

Zakon o zakonski zvezi in družinskih razmerjih. (ZZZDR-UPB1) (2004). Uradni list RS, št. 69/2004 z dne 24. 6. 2004. Pridobljeno s http://www.uradni-list. si/1/objava.jsp?urlid=200469\&stevilka $=3093$ 
Zalokar, L. (2013). Evalvacija institucionalnega obravnavanja mladinske odklonskosti - primer Vzgojnega zavoda Planina (Doktorska disertacija). Univerza v Ljubljani, Pedagoška fakulteta, Ljubljana.

Zrim Martinjak, N. (2006). Koncept socialnega kapitala. V M. Sande, B. Dekleva, A. Kobolt, Š. Razpotnik in D. Zorc Maver (ur.), Socialna pedagogika: izbrani koncepti stroke (str. 37-50). Ljubljana: Pedagoška fakulteta. 


\title{
Kaj vpliva na uspešno vključevanje priseljenskih učencev $\mathrm{v}$ slovenske šole
}

\author{
Andreja Sinjur \\ OŠ Dušana Bordona Semedela, Koper \\ Univerza na Primorskem, Pedagoška fakulteta
}

\section{Uvod}

Na vključevanje priseljenskih učencev v slovenski vzgojno-izobraževalni sistem ne vplivajo le različne politike vključevanja, temveč tudi nekateri drugi dejavniki. ${ }^{1}$ Bourdieu (1986) meni, da je izobraževalna uspešnost posameznika odvisna od ekonomskega, socialnega in kulturnega kapitala.

Ekonomski kapital je vir, ki ga je možno takoj in neposredno zamenjati za denar, in kar se institucionalizira v lastninskih pravicah. Sem torej lahko štejemo vse posameznikove prihodke in premoženje, vključno z vrednostnimi papirji, nepremičninami, živino itd. Ekonomski kapital je vir drugih kapitalov (in tudi njihova posledica), a preobrazba iz ene oblike kapitala v drugo ni nujno enostavna in brez dodatnih stroškov - npr. denar sicer omogoča lažji dostop do izobrazbe, a šolanje je dolgotrajno in truda polno početje; koristi, ki jih lahko imamo od ,zvez in poznanstev', torej od socialnega kapitala, so marsikdaj rezultat dolgoletnega negovanja stikov (Bourdieu, 1986/1997, str. 47).

Socialni kapital je agregat dejanskih in potencialnih virov, ki izvirajo iz posameznikovih omrežij bolj ali manj institucionaliziranih odnosov in se kažejo v članstvu in/ali pripadnosti določeni družbeni skupini, za katero veljajo specifične socialne konvencije o tem, kaj pomeni biti član skupine in kaj so obveznosti članov za ohranjanje članstva. Količina socialnega kapi-

1 Prav tako »Integracija posameznika, kot ena vodilnih instanc socialne pedagogike, postaja vse težja.« (Marovič in Bajželj, 2015, str. 27). 
tala, ki ga posameznik lahko poseduje, je odvisna od mreže povezav, ki jih lahko učinkovito mobilizira, in od količine kapitala (ekonomskega, socialnega, kulturnega), s katerim razpolagajo ljudje njegovega omrežja. Socialni kapital ni odvisen od enkratnega vložka, temveč zahteva vztrajno vlaganje in vzdrževanje, če želimo, da bi si z odnosi iz omrežja lahko na krajši ali daljši rok zagotovili materialne in simbolne profite (Bourdieu, 1986/1997, str. 51-52; prim. Coleman, 1999).

Kulturni kapital je oblika kapitala, ki jo je razvil Bourdieu (1986), da bi pojasnil neenakosti dosežkov otrok, ki izhajajo iz različnih družbenih razredov v povezavi $\mathrm{z}$ akademskim uspehom. Kulturni kapital vključuje demografske značilnosti in zdravje posameznika: vrednote, tradicijo, vzgojo in omiko, jezik, znanje, veščine, poznavanje pravil in motivacijo pa tudi posedovanje knjig, slik ali oblačil. Najpogosteje ga merijo s stopnjo izobrazbe (Bourdieu, 1986).

To pomeni, da na uspešno vključevanje priseljenskih učencev in na njihove izobraževalne dosežke ne vplivajo le države s svojo politiko vključevanja, temveč tudi dohodek staršev, ki pogojuje njihovo zmožnost investiranja v prihodnost svojih otrok; čas, ki ga starši posvečajo svojim otrokom; odnos šole in lokalne skupnosti do priseljenskih učencev in njihovih staršev; usvajanje in učenje drugega/tujega jezika itd. V nadaljevanju predstavljamo nekaj dejavnikov, ki vplivajo na uspešno vključevanje priseljenskih učencev v vzgojno-izobraževalni sistem.

\section{Družbeni razred in družinsko okolje}

Številne empirične raziskave (OECD, 2006; 2007; 2010; 2011; 2012) kažejo, da je šolski uspeh priseljenskih otrok bistveno slabši od uspeha njihovih »domačih" vrstnikov. O tem poročajo tudi Colombo, Cvajner in Sciortino (2008), ki opozarjajo na pomembne probleme politike na tem področju. Prvi je ta, da so priseljenski otroci po vsej EU skoraj brez dvoma izpostavljeni izrazitemu tveganju, da jim bo šlo v šoli slabše kot domačinom. Zato je verjetneje, da ne bodo optimalno sodelovali na trgu delovne sile in da bodo tvegali višjo stopnjo brezposelnosti, verjetnejša pa je tudi široka medgeneracijska reprodukcija neenakosti med otroki domačinov in otroki priseljencev. Na podlagi zgoraj omenjenih raziskav so prišli do zaključkov, da otroci tujega porekla doživljajo pristransko povračilo vlaganja v človeški kapital ${ }^{2}$

Človeški kapital se nanaša na izobrazbo, znanje in kompetence posameznika. Ne moremo ga kupiti ali prodati, lahko ga dobimo le z investiranjem v človeka. Človeški kapital se imenuje človeški zato, ker je del človeka, kapital pa zato, ker je vir prihod- 
v skoraj vseh zahodnoevropskih državah (pravzaprav v vseh razvitih državah). Takšno prikrajšanost zlahka prepoznamo celo ob upoštevanju drugih dejavnikov, kot je družbeni razred, iz katerega izhajajo. Znano je namreč, da igra družbeni razred družine pomembno vlogo pri doseženi stopnji šolske izobrazbe. Zato se je pojavila trditev, da se zabeleženi obseg etničnih razlik v doseženi šolski izobrazbi močno zmanjša ali celo izgine, ko začnemo nadzorovati družbeni razred (Colombo idr., 2008). To tezo zagovarja Bourdieu (1986), ki pravi, da otroci srednjega in višjega razreda $v$ šoli lažje uspevajo zaradi ustreznega kulturnega in socialnega kapitala ${ }^{3}$ (se bolj vključujejo v kulturno življenje in dejavnosti v skupnosti itd.), medtem ko otroci delavskega razreda dosegajo slabše rezultate predvsem zaradi svojih drugačnih kulturnih značilnosti in ne zaradi manjših sposobnosti ali manjšega znanja. Bourdieu zlasti opozarja, da nižjih družbenih razredov pri uveljavljanju v družbi ne ovirajo samo manjša ekonomska sredstva (ekonomski kapital), temveč se srečujejo tudi s kulturnimi ovirami. Različne kulturne značilnosti so namreč v družbi različno cenjene, zato lahko te kulturne razlike krepijo in stopnjujejo razredne razlike. Večina skupin neevropskega porekla pravzaprav še naprej, $v$ drugi (in naslednjih) generacijah, občuti precejšnje etnične sankcije, povezane s trgom delovne sile. V mnogih zahodnoevropskih državah so skoraj vse skupine neevropskega porekla v slabšem položaju, tako glede stopnje brezposelnosti kot tudi glede dostopa do visoko kvalificiranih zaposlitev na trgu delovne sile. Otroci tujega porekla so tudi pogosteje vključeni v poklicno usposabljanje. Zanje je verjetneje, da šole ne bodo končali, dosežena stopnja šolske izobrazbe teh otrok pa je nižja. V zahodnoevropskih državah ni konsistentnega vzorca glede etničnega izvora, čeprav v skoraj vseh državah obstajajo zelo različni nivoji dosežkov znanja med učenci različnega etničnega izvora (Analiza dobrih praks v evropskih šolskih sistemih, 2010).

Te raziskave na splošno kažejo, kako odločilno in nujno je, da bi si evropske družbe skupaj prizadevale upreti strukturnim in sistemskim težnjam po reprodukciji medgeneracijske neenakosti glede na etnično pripadnost ali pa vsaj poskušale zmanjšati njihovo resnost. Toda vzroke za takšne procese je še posebej težko prepoznati, saj priseljenske družine v zahod-

njih zaslužkov. Človeški kapital je lahko investicija v šolanje in višjo izobrazbo, investicija $\mathrm{v}$ pošolsko učenje in usposabljanje, investicija $\mathrm{v}$ predšolske učne aktivnosti, investicije v notranje migracije, investicije v zdravje (Schultz, 1968; 1971).

3 »Socialni kapital /.../ ustvarja bistvene spremembe v našem življenju. Vpliva na psihološke in biološke procese ter s tem zvišuje ali znižuje vrednost našega življenja.« (Marovič, 2010, str. 262). 
noevropski družbeni strukturi niso enakomerno zastopane. Priseljenskih družin je pravzaprav mnogo več med družinami delavskega razreda, zato je tudi njihova izobrazbena struktura nižja, kar je značilno za vse države članice EU. ${ }^{4}$ Vehovar, Makarovič, Podgornik in Černič (2009) so ugotovili, da je imelo od delovno aktivnih, ki so se v Slovenijo priselili v letu 2005, $60,9 \%$ oseb osnovnošolsko izobrazbo, 30, 6 \% srednješolsko, medtem ko je imelo višje- ali visokošolsko izobrazbo le 6,3 \% oseb.

Da je šolski uspeh priseljenskih otrok bistveno slabši od uspeha njihovih domačih vrstnikov, so ugotovili že v šestdesetih letih prejšnjega stoletja. Nižji uspeh so pripisovali zgolj neustrezni družinski vzgoji in socializaciji. S tem se delno strinjajo tudi Colombo idr. (2008), ki menijo, da večina neenakosti pravzaprav izhaja iz razrednega in ne iz etničnega položaja, kar pomeni, da bi morale politike socialnega vključevanja ${ }^{5}$ to tudi bolj upoštevati. Podobno meni tudi Levin (2003), saj vidi potrebo po uveljavljanju celovitih politik in ukrepov na ravni izobraževalnega sistema ter celotne družbe. Tudi v sedemdesetih letih prejšnjega stoletja so različni raziskovalci družbene reprodukcije preučevali odnos med dosežki učencev in izobrazbeno ravnjo družinskih članov vseh učencev, ne samo priseljenskih, kjer pa niso bili upoštevani mnogi drugi vidiki, ki prav tako pomembno vplivajo na učni uspeh. V Analizi dobrih praks $v$ evropskih šolskih sistemih (2010) je zaslediti, da je eden od prezrtih vidikov pomembnost vključevanja priseljenskih družin in skupnosti v izobraževalni proces, drugi pa je lahko tudi ta, kot ugotavljajo Vehovar idr. (2009), da se večina dokumentov s priseljensko tematiko ne ukvarja s kakovostjo družinskega okolja, ki igra ključno vlogo pri razvoju kognitivnega potenciala revnih, marginaliziranih ali priseljenskih otrok. S tem se strinjajo tudi Colombo idr. (2008), ki pravijo, da obstaja mnogo oblik prikrajšanosti za (vsaj) nekatere podskupine otrok priseljencev v izobraževalnem sistemu in na trgu delovne sile. Na tem mestu naj izpostavimo le raziskavi OECD (2006; 2009), v katerih so zbirali podatke o številu knjig, ki jih imajo otroci doma, in o številu ur, ki jih družine in otroci posvetijo branju. Čeprav so ti indikatorji uporabni, ker zagotavljajo informacije o izobraževalnih virih $\mathrm{v}$ gospodinjstvu, niso dobra podlaga za pripravo strategij, s katerimi lahko izboljšamo šolski uspeh. Če analiziramo povezavo med izobrazbeno ravnjo staršev in uspehom učencev samo s podatki, kot je število knjig doma, tvegamo sklep, da se bo šolski uspeh

4 Več o tem v SURS-u.

5 Socialna politika je vrsta ukrepov za izboljšanje delovnih in življenjskih pogojev aktivnega in za delo nezmožnega prebivalstva. 
otrok izboljšal, če bodo imeli doma več knjig. Posledica tega je, da so raziskovalci nekako uzakonili to "realnost «, ki se je vse do danes ohranila v številnih mednarodnih raziskavah (Analiza dobrih praks v evropskih šolskih sistemih, 2010). Če uporabimo podatke o izobrazbeni ravni staršev, obstaja nevarnost, da ne pridemo do nobene druge rešitve, vse dokler družba ne izboljša izobrazbene ravni vseh družin. Posledica tega je, da so drugi vidiki oz. vplivi na šolski uspeh priseljenskih otrok prezrti. Eden izmed takih vidikov je na primer ideja, da se uspeh otrok izboljša, če imajo več interakcij v izobraževalnem procesu, kar vključuje interakcije s pripadniki drugih kultur in zlasti z družinskimi člani. Drugi indikator bi lahko bilo število tečajev, ki jih obiskujejo družinski člani, in kako se s tem spodbujajo tovrstne interakcije ter izboljša šolski uspeh učencev in dijakov (Analiza dobrih praks v evropskih šolskih sistemih, 2010, str. 68).

Da so izobrazbeni dosežki pomembno povezani s komunikacijo staršev in otrok, pričakovanji staršev in starševskim nadzorom, vpletenostjo staršev v delovanje šol in sodelovanjem staršev s šolo, so v svojih raziskavah ugotovili tudi mnogi drugi raziskovalci (npr. McNeal, Pong, Sun, Carbonaro, Morgan in Sørensen; Pribesh in Downey, v Dika in Singh 2002, str. 40-42). Faktorji, ki pozitivno vplivajo na izobrazbene dosežke učencev, so tudi sodelovanje učencev $\mathrm{v}$ šolskih organizacijah in skupnosti, število tesnih prijateljev, ki obiskujejo isto šolo, in vezi med sovrstniki. To pomeni, da imajo zelo pomembno vlogo pri doseganju šolskega uspeha tudi vzgojno-izobraževalne institucije, ki prispevajo $\mathrm{k}$ občutku sprejetosti, povezanosti, k občutku varnosti, enakopravnosti in enakovrednosti vseh učencev. Podobno razmišlja tudi Knaflič (1991), ki meni, da so celotno šolsko (socialno in kulturno) vzdušje ter stališča šole in odnos do otrok, ki ne pripadajo večinskemu prebivalstvu, pomembni dejavniki pri doseganju šolskega uspeha.

\section{Odnos šole in lokalne skupnosti do priseljenskih učencev}

Šola in lokalna skupnost imata kot socializacijska dejavnika pri vključevanju priseljencev pomembno vlogo. R. Bešter (2006; 2009) poudarja, da je prav izobraževanje ključnega pomena za proces vključevanja priseljenskih otrok v novo okolje. $V$ tem procesu otroci pridobijo veščine, znanja in socialne vezi, ki so izredno pomembne za uspešno integracijo in kvaliteto posameznikovega življenja.

Delors idr. (v Medvešek, 2006, str. 144) menijo, da je šola javni prostor, kjer se srečujejo učenci različnih etničnih, verskih in kulturnih pripad- 
nosti. $\mathrm{V}$ nekaterih šolah je kulturna raznolikost večja, $\mathrm{v}$ drugih manjša. Zavedati se je treba, da je tudi razred s samo slovensko govorečimi učenci, rojenimi v Sloveniji, večkulturni, večetnični razred. Različne življenjske izkušnje, osebnosti, spol, različno socialno-ekonomsko okolje izvora, etnična pripadnost - vse to ustvarja večkulturnost. Šola kot taka je zelo primeren prostor oz. institucija, ki bi opremila (naučila) učence za življenje v raznovrstni, demokratični družbi (»learn to live together«).

$\mathrm{V}$ šoli in lokalni skupnosti učenci pridobivajo medosebne spretnosti in veščine komunikacije $\mathrm{z}$ različnimi ljudmi in skupinami, razvijajo prijateljske medosebne odnose, s čimer širijo svoj socialni kapital, ter si izoblikujejo življenjske cilje za prihodnost. Številne raziskave (Braddock; Eccles in Barber; Guiterezz idr.; Jordan, v Banks in Banks, 2001) dokazujejo pozitivno povezanost med dosežki učencev in njihovo udeležbo $v$ izvenšolskih dejavnostih. Udeležba $\mathrm{v}$ zunajšolskih dejavnostih (ne nujno $\mathrm{v}$ kulturnih in jezikovnih tečajih, ampak tudi $\mathrm{v}$ športnih aktivnostih) povzroča višje dosežke učencev. Prav tako izboljša disciplino in preprečuje osip. Okolje zunajšolskih dejavnosti (kot oblika neformalnega učenja) spodbuja druženje pripadnikov različnih kultur. Pomembno je, da spodbujamo predvsem takšne dejavnosti, v katerih imajo učenci enakopraven status. Da bi izboljšali odnose med skupinami, je zaželeno ustanoviti tudi skupine, ki jih predstavljajo pripadniki različnih skupin, s katerimi se lahko vsi člani identificirajo. Takšne skupine zmanjšujejo predsodke do drugih skupin, saj imajo (različne) skupne identitete, to je pripadnost skupini, navedeno pa prispeva k zmanjševanju nestrpnosti med člani (Banks in Banks, 2001, v Klemenčič in Štremfel, 2011). Resman (2003) dodaja, da je cilj šolske vzgoje oblikovanje ljudi (otrok, učencev) za mirno sožitje različnih socialnih, kulturnih in drugih skupin človeštva ter vsajanje vrednot, kot so večkulturnost, medkulturnost, razumevanje, pluralizem, toleranca, spoštovanje drugačnosti. V nasprotnem primeru lahko pride do stereotipiziranja, pomanjkanja spoštovanja do drugih kultur, diskriminacije in rasizma. Haji Kella (2001, str. 92) pravi, da smo ljudje nagnjeni k "predalčkanjem« drugih. To nam pomaga oblikovati svoj svet in se v njem počutiti varno. Druge ljudi razvrščamo v kategorije, kot so spol, rasa, socialni status itd. Ker želimo ustvariti čim boljši svet zase, postavljamo ljudi z lastnostmi, ki so nam blizu, na višjo pozicijo, na ostale pa začnemo gledati kot na manj vredne.

Ko se posameznik poda izven lastnega kulturnega okolja in je obkrožen ter soočen z drugo kulturo, običajno doživi kulturni šok. Ko pa je posameznik v lastnem kulturnem okolju (neprostovoljno) soočen s tujo kulturo 
(npr. ko se v njegovo okolje priselijo ljudje druge kulture), se pogosto pojavi občutek ogroženosti lastne kulturne identitete ter občutki etnocentrizma. Etnocentrizem je dojemanje lastne kulture kot večvredne in podcenjevanje ostalih kultur (Haji Kella, 2001, str. 97). Taylor (1995, str. 32-33) pravi, da gre pri etnocentrizmu za naše prepričanje, da so naše vrednote in naš način življenja univerzalni, najboljši za vsakogar, in da »drugi« tega preprosto ne vidijo ali ne razumejo. En sam stik z osebami iz druge kulture lahko zato še okrepi naše predsodke, saj gledamo skozi očala etnocentrizma. Nekatere kulture se nam sicer zdijo eksotične, večinoma pa imamo negativne predsodke $^{6}$ in stereotipe ${ }^{7}$ o drugačnih ter jih zavračamo. To sta v svoji raziskavi potrdili tudi M. Peček Čuk in I. Lesar (2006), po katerih so bili učitelji v dilemi ali so celo izrazili nepripravljenost, da bi v svoj razred sprejeli Roma, priseljenca iz bivše Jugoslavije ali učenca s posebnimi potrebami. Pri slednjih je bila stopnja pripravljenosti sprejetja odvisna od učenčeve motnje.

Tudi zaradi nezavedanja lastnih predsodkov in stereotipov lahko pride do pojava diskriminacije, ki je $\mathrm{v}$ tesni korelaciji $\mathrm{z}$ obema pojmoma (stereotipi in predsodki), saj sleherna diskriminacija $\mathrm{v}$ osnovi temelji na stereotipih in predsodkih, vendar $\mathrm{v}$ vsakdanji uporabi pojma predsodek in diskriminacija pogosto zamenjujemo. $\mathrm{V}$ bistvu se nanašata na različne stvari - medtem ko je predsodek stališče, skupek prepričanj o nekem posamezniku ali skupini, ki so utemeljena zgolj na osnovi njegove pripadnosti določeni skupini oz. značilnostih te skupine, pa je diskriminacija različna obravnava posameznikov zaradi njihovih posebnosti, ki so označene kot drugačne, in zaradi njihove pripadnosti »označenim« skupinam (Nastran Ule, 1997). Poznamo različne oblike, načine in prakse diskriminacije, ki se v najbolj splošni obliki dogaja preko družbenega izključevanja. V pravnem smislu diskriminacijo označimo kot $\mathrm{z}$ zakonom prepovedano neenako obravnavanje osebe ali skupine $\mathrm{v}$ primerjavi $\mathrm{z}$ drugo osebo, skupino zaradi ene/

6 Glavna razlika med stereotipi in predsodki je močna čustvena komponenta, ki je izražena pri predsodkih, medtem ko stereotipi temeljijo zgolj na kognitivni komponenti (na nepreverjenih dejstvih ali govoricah). Stereotip je pravzaprav rezultat nujnosti, sklepanja na osnovi omejenih informacij in obenem potrebe, da poenostavimo kompleksnost pojavov in dogajanj v svetu. Torej so stereotipi neke vrste predstopnja predsodkov (Nastran Ule, 1992, str. 121). Obstaja več teoretskih razlag, ki izvore o predsodkih tolmačijo drugače. Prvi pravijo, da predsodki izhajajo iz prirojenega strahu pred vsem tujim, nerazumljivim, drugačnim oz. iz potlačenih frustracij ljudi. Drugi, da izhajajo iz določene strukture osebnosti (anksiozne, negotove vase, avtoritarne). Tretji iščejo vzroke v socialnem okolju (starši, družina, tradicija, vrstniki, množični mediji) (Nastran Ule, 200o, str. 174).

7 Glej zgornjo opombo. 
več osebnih okoliščin. V širšem sociološkem smislu je diskriminacija oblika družbene prakse, ki praviloma temelji na predsodkih in stereotipih, zakoreninjenih v kulturi določene družbe. Če strnemo, je diskriminacija vsaka praksa, ki določenim posameznikom ali skupinam onemogoči uživanje njihovih pravic in svoboščin in jih $\mathrm{v}$ primerjavi $\mathrm{z}$ ostalimi člani določene politične ali družbene entitete postavlja v slabši položaj ter jih $\mathrm{v}$ fizičnem ali simbolnem pomenu odriva na rob družbe (Kuhar, 2009, str. 15). Posledice diskriminacije so lahko zelo različne, najpogosteje pa vodijo v marginalizacijo in socialno izključenost.

Učitelji predstavljajo pomemben dejavnik pri vključevanju/izključevanju priseljenskih učencev $\mathrm{v}$ razred. S tem se strinja tudi Berdajs (2016, str. 9), ki meni, da "veliko ovir pri vključevanju priseljenskih učencev v razrede povzročijo ravno učitelji«. Njihova stališča in pričakovanja ter njihovo strokovno znanje so odločilnega pomena pri ustvarjanju pozitivnega učnega okolja za vse (priseljenske) učence. Gay (1986) opozarja, da imajo učitelji, ki so slabo »opremljeni« za delo v kulturno raznolikem razredu, ponavadi bolj negativen odnos do priseljenskih učencev in niso naklonjeni spremembam, kar pa lahko vodi, kot trdi Gay (2002, str. 614), v to, da ti učenci izgubijo zanimanje za učenje. To pa lahko vpliva na njihov akademski dosežek in na njihovo nadaljnje življenje. S tem se strinjata tudi Vah Jevšnik in Toplak (2011, str. 41), ki pravita, da lahko učitelji zaradi raznolikosti in heterogenosti učencev v razredu naletijo na različne težave, zlasti če niso dovolj ozaveščeni, empatični ali ne obvladajo pristopov, ki so primerni v tovrstnih razredih - torej nimajo razvitih medkulturnih kompetenc. ${ }^{8}$ Zaradi tega lahko (pogosto) pride do nenamerne in nezavestne diskriminacije otrok $\mathrm{z}$ različnim etničnim, kulturnim in/ali socialnim ozadjem. Diskriminacija, neposredna ali posredna, ima trajne negativne posledice za motivacijo za učenje priseljenskih učencev, to pa ima lahko dolgoročne negativne vplive na celoten potek njihovega življenja.

Razlog za nezmožnost dojemanja lastnih predsodkov in stereotipov ter pomanjkanje kritične refleksije učiteljev je lahko tudi posledica pomanjkanja več-/medkulturnih vsebin, s katerimi naj bi se (bodoči) učitelji seznanili tako med samim študijem kot tudi v svojem nadaljnjem poklicnem izobraževanju. Eden od razlogov, kot pravi Talib (2006), bi lahko bil tudi ta, da učitelji pogosto prihajajo iz monokulturnega okolja, zato je še toliko večji razlog, da bi jih morali nujno seznaniti $z$ večkulturnimi vsebinami.

8 Več-/medkulturne kompetence pridobimo s poznavanjem jezikovne in kulturne raznolikosti in so predpogoj za uspešno delo $\mathrm{v}$ etnično/kulturno mešanem razredu. 
Poleg več-/medkulturnih vsebin bi morali (bodoče) učitelje seznaniti tudi s poučevanjem slovenščine kot drugega/tujega jezika, jih seznaniti $\mathrm{z}$ metodami poučevanja in preverjanja znanja slovenščine kot drugega/tujega jezika. Priseljenski učenci se namreč vključujejo v razrede, v katerih se slovenščina poučuje zgolj kot prvi jezik. Posledica tega je, da so ti učenci večkratno prikrajšani, saj težko sledijo pouku in zato tudi dosegajo slabše učne rezultate ter se slabše vključujejo v vzgojno-izobraževalni sistem.

(Bodoče) učitelje je torej potrebno izobraževati za poučevanje slovenščine kot drugega/tujega jezika, saj je $z$ nanje jezika države gostiteljice eden od nujnih predpogojev za vključevanje priseljenskih otrok v šolsko okolje in njihovo izobrazbeno uspešnost (Marjanovič Umek, Sočan in Bajc, 2007). Tako bi se verjetno izognili tudi odsotnosti kritične refleksije lastne prakse pri učiteljih, ki poučujejo priseljenske učence, njihovi nepripravljenosti za presojo lastnih stereotipnih predstav in predsodkov ter nepripravljenost za presojo lastnega vpliva na odnos do priseljenskih učencev.

\section{Usvajanje in učenje drugega/tujega jezika}

Zelo pomemben dejavnik, ki vpliva na uspešno vključevanje priseljenskih učencev v sistem vzgoje in izobraževanja ter družbo na splošno, je jezik države gostiteljice (v našem primeru slovenščine). Strategija (2007, str. 12) navaja tri pomembne stvari: (1) razvijanje jezikovne zmožnosti (otroci usvojijo oz. se naučijo zadostnega nabora besedišča, slovničnih in sporazumevalnih vzorcev za uspešno sporazumevanje $\mathrm{v}$ vrtčevskem in šolskem okolju - sporazumevanje s strokovnimi delavci vrtca in $\mathrm{z}$ učitelji, sporazumevanje $\mathrm{z}$ vrstniki, dejavno sodelovanje pri izvedbenem kurikulu oddelka vrtca oz. pri pouku), (2) razvijanje socialne zmožnosti (zmožnost izražanja mnenja, želja, namere oz. ustreznega reagiranja na želje drugih. Otroci imajo to zmožnost že razvito, vendar so jo razvili v lastnem okolju in jo znajo realizirati le $\mathrm{v}$ svojem jeziku ter na način, ki ustreza ustaljenim vzorcem v njihovem sociokulturnem okolju. Učenje jezika je tudi socializacijski proces, prilagajanje novim življenjskim okoliščinam, govornim položajem) in (3) razvijanje spoznavne zmožnosti (širjenje otrokovega pojmovnega sveta, čas vključevanja, način poučevanja, vrednotenje doseženega znanja jezika, socializacija otroka, način sodelovanja s starši, izbor gradiv oz. priprava novih ter uporaba že obstoječih). Vse našteto pa je odvisno od posebnosti ciljne skupine, kot so npr. starost oz. stopnja izobraževanja (vrtec, osnovna šola, srednja šola), socialne okoliščine ter prvi jezik otrok 
migrantov (tu poteka ločnica med otroki iz slovanske jezikovne skupine in otroki iz drugih jezikovnih skupin, npr. germanske, romanske in drugih).

Preden se lotimo tematike jezika, je potrebno opozoriti na razliko med usvajanjem in učenjem drugega/tujega jezika. Razlika izhaja iz okolja, v katerem oseba prihaja $\mathrm{v}$ stik $\mathrm{z}$ drugim/tujim jezikom, ter iz načina, kako pride do tega stika. Usvajanje se nanaša na osebo (otroka ali odraslega), ki je izpostavljena drugemu/tujemu jeziku v naravnem okolju. Učenje drugega/ tujega jezika pa vključuje usmerjeno poučevanje in učenje drugega/tujega jezika v formalnem učnem procesu (Lük Nećak, 1995, str. 13).

Otroci v svoji domovini usvajajo jezik v naravnem okolju. Ko pa se starši skupaj z otroki iz različnih razlogov (selitev, ločitev, mešani zakoni, študij, služba itd.) ločijo od družbe, v kateri so uporabljali materinščino, vstopijo v drug kulturni, socialni in komunikacijski prostor, kjer se srečajo z drugim/tujim jezikom. Če ne prej, je za otroka prvi stik s tem jezikom vrtec oz. šola, ki mu omogoča, da se ob lastnem jeziku nauči tudi jezika družbe, v kateri živi. Resman (2003) pravi, da se bo otrok, ki ne bo obvladal jezika okolja in šole, slabše odzival in vključeval v okolje, pogosteje bo doživljal nesporazume z vrstniki, katerim ne bo enakovreden, zniževala pa se bo tudi njegova motivacija, kar pa lahko privede do tega, da bo otrok zavrt. Jezik je namreč ključ tudi do otrokovega učnega uspeha. K. Skubic Ermenc (2003b, str. 65) pravi, da je Evropa že pred dvema desetletjema sprejela ugotovitev, da učenje maternega jezika ni zgolj pravica manjšinskih etnij do ohranjanja lastne etnične oz. kulturne identitete, temveč je predvsem nujen pogoj za šolski uspeh učencev priseljencev. S tem se strinja tudi Resman (2003), ki pravi, da je prihodnost otrokovega razvoja zelo odvisna od obvladovanja jezika večine, kar velja tudi za njegovo šolsko delo in uveljavljanje v širšem socialnem prostoru. Brez dobro usvojenega jezika ni mogoče vzpostaviti sporazumevanja, brez slednjega pa ni možna niti participacija. Zato tudi ni vseeno, ali je otrokovo družinsko jezikovno okolje revno (npr. se uporablja le jezik manjšine ali celo samo narečje). Otrok, ki obvlada le svoj materni jezik, ki ni jezik socialnega okolja, v katerem družina živi, se bo socialno aktivneje vključeval v družbo šele, ko bo v družbi z vrstniki iz podobnega socialnega okolja. Taki otroci vse svoje sposobnosti pokažejo šele tedaj, ko pridejo v zanje ugodno socialno okolje. Pa vendar je materni jezik tisti, ki otroka spremlja od prvih dni življenja. Materni jezik je jezik naroda, kateremu oseba pripada, in na njem temelji govorni razvoj otroka. B. Hanuš in T. Neuman (1987) pravita, da materni jezik služi za identifikacijo, posameznik pa je nanj čustveno navezan. Tudi Knaflič (1991, str. 39) meni, 
da je materni jezik izraz primarne identifikacije. $\mathrm{Z}$ imenovanjem predmetov in pojavov okoli sebe začne otrok spoznavati svet in svojo kulturo ter vzpostavi svoj stik z okoljem (Knaflič, 1991, str. 39). Ubeseditev v prvem jeziku je oblika ideološkega doživljanja sveta, v katerem otrok živi. Otrok ozavešča norme, vrednote in stališča, pridobiva kulturne navade, spoznava življenjski slog v neposredni okolici, oblikuje svojo etično in osebnostno individualnost (Čok, Skela, Kogoj in Razdevšek-Pučko, 1999). K. Skubic Ermenc (2003b, str. 65) celo navaja, da številne raziskave potrjujejo, da imajo otroci, ki ne obvladajo globlje svojega maternega jezika, lahko težave pri učenju drugega/tujega jezika. Lahko postajajo poljezični, ${ }^{9}$ ne pa dvojezični govorci. S tem se strinjata tudi B. Hanuš in T. Neuman (1987), ki menita, da je učenje drugega/tujega jezika mnogo lažje ob predpostavki, da dobro obvladamo materni jezik.

Učenje jezika države gostiteljice in jezikovno sporazumevanje sta pri vključevanju priseljenskih otrok in njihovih staršev v šolsko okolje ter lokalno skupnost dve najpomembnejši nalogi. Če želi biti posameznik uspešen $\mathrm{v}$ družbi, se mora ne samo naučiti slovničnih in pravopisnih pravil, temveč tudi razvijati sporazumevalne zmožnosti. S tem se strinja tudi K. Skubic Ermenc (2003a, str. 53), ki pravi, da učenčevo obvladovanje jezika na pogovorni ravni še ne pomeni, da je sposoben razumeti in producirati akademska besedila. Medveš (2006) trdi, da je razvijanje sposobnosti za komunikacijo ( $\mathrm{tj}$. sposobnost ustnega in pisnega izražanja, sposobnost poslušanja oz. slušnega sprejemanja informacij, sposobnost spreminjanja slišnih informacij $\mathrm{v}$ pisne, sposobnost razumevanja informacij, sposobnost odločanja in delovanja na podlagi sprejetih informacij) ena od glavnih nalog pri učenju jezika.

Thomas in Collier (v Smyth, 2001) sta v svoji 14-letni raziskavi učnega uspeha $\mathrm{v}$ petih šolskih okrajih $\mathrm{v}$ Združenih državah Amerike ugotovila, da je prvi znanilec dolgoročnega šolskega uspeha (za učence iz jezikovne manjšine): (1) kognitivno kompleksno diferencirano šolanje $\mathrm{v}$ učenčevem maternem jeziku čim dlje je mogoče in (2) kognitivno kompleksno diferencirano šolanje $\mathrm{v}$ učenčevem drugem/tujem jeziku del šolskega dneva. V njuni raziskavi je sodelovalo 700.000 dvojezičnih učencev. Za vse sodelujoče učence je bil jezik v razredu večinski jezik ( $t j$. angleščina).

9 Poljezičnost (ali semilingvizem) je tisto stanje v dvojezičnosti, v kateri sta jezikovna in sporočanjska zmožnost v obeh jezikih zelo skromni (Bernjak, 200o). Poljezičnost je podobno kot absolutna dvojezičnost (brezhibno ustno in pisno obvladovanje dveh ali več jezikov) zelo redek pojav, zato se ta izraz danes uporablja samo v patoloških primerih nesposobnosti izražanja v zelo marginaliziranih družbenih kontekstih. 
Pogovori s pedagogi so pokazali, da so bili mnogi navedeni izobrazbeni cilji učiteljev glede dvojezičnih otrok povezani z njihovo socializacijo. To pomeni, da so jim omogočili celostno udeležbo v enojezični šolski skupnosti. Ob opazovanju pouka so bili razvidni jezikovni cilji enojezičnosti v večinskem jeziku, ki so odsevali splošni cilj v šolah, da bi dvojezične učence jezikovno in kulturno asimilirali $\mathrm{z}$ večinskim jezikom in kulturo. Ti cilji pa so v skladu z Bakerjevim (v Smyth, 2001) tipom izobraževanja dvojezičnih otrok, ki ga imenuje »preplavljanje« in ga označuje kot najšibkejšo obliko izobraževanja v smislu spodbujanja dvojezičnosti. To "preplavljanje« ali "potopitev v enojezičnost « Cummins (1984, str. 156) označuje kot tip dvojezičnega izobraževanja, ki vključuje neko obliko prilagojenega učenja drugega/tujega jezika, vendar brez dvojezičnih učiteljev in brez uporabe znanja prvega jezika. Tak program lahko učinkovito prispeva $\mathrm{k}$ znanju angleščine, vendar Cummins dokazuje, da vodi k okrnjeni obliki dvojezičnosti, in sicer zaradi nižjega statusa učenčevega prvega jezika in pomanjkanja pisnih izkušenj v prvem jeziku.

Thomas in Collier (v Smyth, 2001) sta v svoji longitudinalni raziskavi preučevala tudi učinkovitost šestih oblik izobraževalnih ukrepov za dvojezične učence, ki so začeli šolanje $z$ malo znanja angleščine. Šest analiziranih oblik programov je imelo različne izobrazbene cilje. Najuspešnejši so bili programi, ki so omogočali ohranitev maternega jezika skupaj z učenjem drugega/tujega jezika, medtem ko so bili programi z najslabšimi rezultati in učnim uspehom dvojezičnih učencev tisti, ki so se osredotočali samo na angleščino. Narejenih je bilo tudi veliko empiričnih raziskav (npr. OECD, 2006; 2007; 2010; 2011; 2012), katerih skupni imenovalec je prav tako, da imajo priseljenski otroci, ki se ne šolajo $\mathrm{v}$ maternem jeziku, lahko težave na učnem, socialnem in emocionalnem področju ter na področju vedenja. V šolski praksi se to lahko kaže na različne načine, in sicer kot: pogosto podpovprečni učni rezultati; slabše bralne sposobnosti; slabše razumevanje prebranega; motena pozornost poslušanja; šibko jezikovno pomnjenje; slabše slušno pomnjenje; težave pri strukturiranju stavkov; pogoste napake v artikulaciji (izgovarjanju) glasov; nepravilno zapisovanje besed; nerazumevanje navodil; slabo razumevanje navad in pričakovanj države gostiteljice; impulzivnost; visoka stopnja negotovosti; posnemanje dela drugih, zlasti pri individualnih zahtevah; strah in sram pred socialnimi stiki; socialna osamljenost in nezainteresiranost. Na tem mestu bi izpostavili, da nekateri priseljenski učenci izražajo veliko višjo stopnjo pripravljenosti za šolsko delo od svojih »domačih" sovrstnikov. To potrjuje tudi A. Miketič (2009), 
ki je v svoji magistrski raziskavi ugotovila, da imajo priseljenski učenci obravnavane osnovne šole bolj izraženo storilnostno naravnanost kot nepriseljenski učenci primerjalne skupine na drugi šoli. To povezuje s tem, da morajo priseljenski učenci, glede na to, da slovenščina ni njihov materni jezik, vložiti veliko več truda v učenje kot njihovi domači vrstniki. Ugotovila je tudi, da priseljenski učenci velikokrat učitelja sploh ne razumejo, niti ne upajo tega povedati. Posledica tega pa je, da učitelji takšno situacijo največkrat razumejo kot nezainteresiranost učencev.

$\mathrm{V}$ razpravi o nenehnih slabših rezultatih dvojezičnih učencev $\mathrm{v}$ Evropi, Kanadi in Združenih državah Amerike bi bilo dobro upoštevati Cumminsov teoretični okvir za usposabljanje in vključevanje manjšinskih učencev. Cummins (1986, str. 24) namreč pravi, da za slabši uspeh ni kriva dvojezičnost, temveč da pri poučevanju dvojezičnih otrok nekaj manjka. Avtor nadaljuje, da je potrebno učinke ukrepovv zvezi z dvojezičnimi učenci upoštevati skupaj z nenehnim usposabljanjem onesposobljenih dvojezičnih učencev, saj $\mathrm{k}$ stopnji usposobljenosti manjšinskih učencev prispevajo štirje strukturni elementi $\mathrm{v}$ organizaciji šolanja: (1) vključevanje kulture in jezika manjšinskih učencev, (2) vključevanje manjšinskih skupnosti v izobrazbo njihovih otrok, (3) pedagoške predpostavke in prakse v razredu in (4) ocenjevanje manjšinskih učencev. Temeljna teza Cumminsovega modela ${ }^{10}$ je ta, da bi morala biti šola pozitivno naravnana do dvojezičnih otrok, dvojezičnost pa bi morala veljati za nekaj pozitivnega in ne za problem. Mnoge raziskave (npr. Skutnabb-Kangas, 1981; Cummins, 1984; Gibbons, 1991; Thomas in Collier, v Smyth, 2001) so pokazale, da ima mišljenje učiteljev o dvojezičnosti kot pomanjkljivosti škodljive posledice za šolski uspeh dvojezičnih otrok, zato ti učenci nimajo priložnosti, da bi postali dvojezični z vsemi kognitivnimi, osebnimi in družbenimi prednostmi, ki jih imajo $\mathrm{v}$ celoti funkcionalni dvojezični govorci. Učenci, ki niso enojezični v dominantnem jeziku razreda, nimajo priložnosti, da bi uporabljali svoj prvi jezik za ustvarjalne namene. Te raziskave tudi nakazujejo, da je za dvojezične učence najbolje, če jim šola omogoča vzdrževanje znanja prvega jezika vzporedno $\mathrm{z}$ razvijanjem drugega jezika. Thomas in Collier (v Smyth, 2001) sta jasno pokazala, da se $\mathrm{z}$ enojezično izobraževalno podporo dvojezičnim učencem ne da premostiti razlike $\mathrm{v}$ šolskem uspehu med dvojezičnimi in enojezičnimi. To pomeni, da dvojezičnim učencem ne more zagotoviti doseganja njihovega izobrazbenega potenciala.

10 Več o modelu v Cummins, $1986 .$. 
Usvajanje jezika države gostiteljice je torej zelo pomembno sredstvo socializacije. S tem se strinja tudi Resman (1996), ki pravi, da je jezik eden najpomembnejših dejavnikov, ki vpliva na otrokov psihosocialni razvoj, oblikuje njegovo samopodobo in etično identiteto (uglašenost otrokovega zaznavanja, njegovo razmišljanje, občutenje in ravnanje) ter v kulturno pluralni družbi (poleg pogleda nase v svoji kulturni skupnosti) zahteva (vključuje) tudi razvoj odnosa do članov drugih skupnosti in kulture drugih. Iz tega pravzaprav izhaja šolska medkulturna vzgoja (Resman, 1996). Tako kot usvajanje jezika je torej pomemben tudi odnos večine do manjšine, ki se zaradi zgoraj naštetih težav priseljenskih otrok velikokrat kaže kot diskriminacija. Prav zato je šola tako zelo pomembna institucija, saj znotraj nje poteka proces vključevanja posameznika $\mathrm{v}$ neko sredino, $\mathrm{v}$ kateri so (oz. naj bi bili) poudarjeni sprejetost, toleranca, sodelovanje, medsebojna komunikacija in prilagajanje. S tem se strinjajo tudi nekateri strokovnjaki (LukšičHacin, 1999; Resman, 2006; Banks, in Banks 2001), ki izpostavljajo šolo kot najpomembnejšo institucijo, ki lahko zagotovi vzpostavitev večkulturnega diskurza in medkulturnega izobraževanja. M. Lukšič-Hacin (1999) celo meni, da je razumevanje medkulturnosti glavno pedagoško orodje večkulturnega izobraževanja, ki je neposredno usmerjeno v konstruktivno vključitev priseljenskih otrok.

\section{Sklep}

$\mathrm{Na}$ uspešno vključevanje priseljenskih učencev v proces vzgoje in izobraževanja v Sloveniji ne vpliva le država s svojo politiko vključevanja, temveč tudi nekateri drugi dejavniki. Učno okolje oz. kulturni kapital staršev je tisti, ki določa kakovost starševskih investicij v svoje otroke, vendar kulturni kapital ni vezan le na dohodek ali izobrazbo, temveč je povezan tudi s starševskim vrednotenjem izobrazbe ter pogojuje kakovost starševskih spodbud.

Za razumevanje načina življenja v novi državi je zelo pomembno usvajanje jezika države gostiteljice in odnos večine do drugačnega ali tujega, ki pa se v praksi velikokrat kaže kot diskriminacija, katere posledica so lahko stigmatizacija, socialna izključenost, marginalizacija in segregacija priseljencev. Šola ima zato pomembno vlogo socializacijskega dejavnika pri vključevanju priseljenskih učencev, izobraževanje pa je ključnega pomena za proces vključevanja priseljenskih otrok $\mathrm{v}$ novo okolje. $\mathrm{V}$ tem procesu otroci pridobijo veščine, znanja in socialne vezi, ki so izredno pomembne za uspešno vključevanje in kvaliteto posameznikovega življenja. Sprejetost pri- 
seljenskih učencev $\mathrm{v}$ šoli ter lokalni skupnosti je namreč ključnega pomena za njihovo nadaljnje vključevanje v družbo, vendar kljub mnogim skupnim načelom (npr. Evropske komisije, javnih razpisov itd.), ki poudarjajo udeležbo priseljencev na lokalni ravni in krepitev sodelovanja priseljencev z lokalnim okoljem, še vedno ostaja dejstvo, da lokalne skupnosti v pravnih podlagah nimajo velike vloge. Šole s priseljenskimi učenci bi zato morale imeti zaposlenega kompetentnega strokovnega delavca (npr. socialnega pedagoga), ki bi predstavljal vez med učitelji, starši priseljenskih učencev, šolo in lokalno skupnostjo, ki bi bil odgovoren za sprejem, vodenje, koordinacijo, vzpostavljanje vezi s šolo in okoljem izven šole, krepitev sporazumevalnih zmožnosti med šolo in družinami, vpenjanje učenčeve družine v šolsko življenje ter sistematično vrednotenje oz. evalvacijo programov, s katerimi šole pomagajo pri vključevanju priseljenskih učencev. V nekaterih drugih državah po svetu (npr. Belgija, Danska, Islandija, Bolgarija, Češka, Poljska, Grčija, Latvija, Lihtenštajn) šolske oblasti izdajo predpise ali priporočila v zvezi z osebjem za pomoč pri vključevanju priseljenskih učencev, njihova glavna naloga pa je začetni sprejem priseljencev in lajšanje vključevanja priseljenskih učencev $\mathrm{v}$ šolo. Na ta način bi se priseljenski učenci izognili stresnim situacijam, kot jo je $\mathrm{v}$ enem od naših intervjujev doživela učenka iz Albanije, in prepričani smo, da ni edina: »Ko sem prvič prišla v šolo, mi je čistilka povedala, kam naj grem, v kateri razred.«

\section{Literatura}

Analiza dobrih praks v evropskih šolskih sistemih. (2010). Andragoški center Republike Slovenije. Pridobljeno s http://www.dlib. si/?URN=URN:NBN:SI:DOC-A4ID638Z

Banks, J. A., in Banks, C. A. M. (2001). Handbook of research on multicultural education. San Francisco, CA: Jossey-Bass.

Berdajs, A. (2016). Socialnopedagoško delo učiteljev z rizičnimi dijaki v strokovnih šolah. V IV. International Scientific conference "Special education and rehabilitacion - early intervention « (str. 196). Beograd: Beogradska defektološka škola.

Bernjak, E. (200o). Nekateri jezikovno politični vidiki izgubljanja manjšinskega (slovenskega) jezika v Porabju. V I. Štrukelj (ur.), Kultura, identiteta in jezik v procesih evropske integracije (str. 108 119). Ljubljana: Društvo za uporabno jezikoslovje. 
Bešter, R. (2006). Integracijska politika - politika integracije imigrantov: teoretični model in študija primera Republike Slovenije (Doktorska disertacija). Univerza v Ljubljani, Fakulteta za družbene vede, Ljubljana.

Bešter, R. (2007). Integracija in model integracijskih politik. V M. Komac (ur.), Priseljenci: študije o priseljevanju in vključevanju $v$ slovensko družbo (str. 105-134). Ljubljana: Inštitut za narodnostna vprašanja.

Bešter, R. (2009). Vključevanje imigrantskih otrok v izobraževalni sistem. Razprave in gradivo: revija za narodnostna vprašanja, 59, 90-114.

Bourdieu, P. (1986) The forms of capital. V J. G. Richardson (ur.), Handbook of theory and research for the sociology of education (str. 241-258). New York, NY: Greenwood Press.

Coleman, L. M. (1999). Stigma - razkrita enigma. V M. Nastran Ule (ur.), Predsodki in diskriminacije: izbrane socialno-psihološke študije (str. 198216). Ljubljana: Znanstveno in publicistično središče.

Colombo, A. D., Cvajner, M., in Sciortino, G. (2008). Priseljevanje: Izzivi in priložnosti na območjih ERLAIM-a. Pridobljeno s http://ec.europa.eu/ ewsi/UDRW/images/items/docl_7030_854526400.pdf

Cummins, J. (1984). Bilingual education and special education: Issues in Assessment and pedagogy. San Diego, CA: College Hill.

Cummins, J. (1986). Empowering minority students: A framework for intervention. Harvard Educational Review, 7(4), 649-676.

Čok, L., Skela, J., Kogoj, B., in Razdevšek-Pučko, C. (1999). Učenje in poučevanje tujega jezika. Ljubljana: Pedagoška fakulteta; Koper: Znanstvenoraziskovalno središče Republike Slovenije.

Dika, L. S., in Singh, K. (2002). Applications of social capital in educational literature: A critical synthesis. Review of Educational Research, (72)1, 30-60.

Gay, G. (1986). Multicultural teacher education. V J. A. Banks in J. Lynch (ur.), Multicultural education in Western societies (str. 154-177). Eastbourne: Holt, Rinehart and Winston.

Gay, G. (2002). Culturally responsive teaching in special education for ethnically diverse students: setting the stage. International Journal of Qualitative Studies in Education, 15 (6), str. 613-629. Pridobljeno 20. 3. 2014, s http:// culturallyresponsiveteaching.weebly.com/uploads/1/8/1/5/18153535/_crt_in_ sped.pdf

Haji Kella, M. (2001). Jeux de simulation'. T-kit L'apprentissage interculturel, 4, $58-65$. 
Hanuš, B., in Neuman, T. (1987). Delo z otroki drugih narodov in narodnosti v Osnovni šoli Karla Destovnika Kajuha. V Z. Jelenc (ur.), Drugačnost otrok $v$ naši šoli: zbornik strokovnega posvetovanja (str. 302-307). Ljubljana: svetovalni center za otroke, mladostnike in starše.

Klemenčič, E., in Štremfel, U. (2011). Nacionalna in mednarodna perspektiva izobraževanja za državljanstvo v večkulturni družbi. Pridobljeno s http:// www.medkulturni-odnosi.si/images/stories/publikacije/Perspektiva.pdf

Knaflič, L. (1991). Neslovenski otroci in šola. Jezikovni problemi otrok, ki se ne šolajo v maternem jeziku. Vzgoja in izobraževanje, 22(2), 38-41.

Kuhar, R. (2009). Na križiščih diskriminacije: večplastna in intersekcijska diskriminacija. Ljubljana: Mirovni inštitut.

Lük Nećak, A. (1995). Dvojezičnost ni dvojna enojezičnost. Otrok v svetu dveh jezikov. Uporabno jezikoslovje, 4, 8-31.

Lukšič-Hacin, M. (1999). Večkulturalizem in migracije. Ljubljana: ZRC SAZU.

Levin, B. (2003). Approaches to equity in policy for lifelong learning. Pridobljenos http://www.oecd.org/dataoecd/50/16/38692676.pdf

Marjanovič Umek, L., Sočan, G., in Bajc, K. (2007). Vpliv psiholoških dejavnikov in izobrazbe staršev na učno uspešnost mladostnikov. Psihološka obzorja, 16(3), 7-48.

Marovič, M. (2010). Romi, socialni kapital ter dileme glede nameščanja romskih otrok v vzgojne zavode. Socialna pedagogika, 14(2), 247-270.

Marovič, M., in Bajželj, B. (2015). Participation - one of the (socio-)pedagogic educational concepts in the time of postmodernity. V M. Krajnčan (ur.), Educational sciences in postmodernity (str. 25-46). Herzogenraft: Shaker Verlag GmbH.

Medveš, Z. (2006). Upoštevanje drugačnosti - korak k šoli enakih možnosti. Sodobna pedagogika, 57(posebna izdaja), 10-41.

Medvešek, M. (2006). Vloga vzgojno-izobraževalnega sistema v procesu družbenega vključevanja/izključevanja potomcev priseljencev v Sloveniji. Sodobna pedagogika, 57(posebna izdaja), 124-147.

Miketič, A. (2009). Motivacijsko-vedenjski stili učencevosnovne šole. Magistrsko delo, Ljubljana: Pedagoška fakulteta.

Nastran Ule, M. (1997). Temelji socialne psihologije. Ljubljana: Znanstveno in publicistično središče.

Nastran Ule, M. (200o). Socialna psihologija. Ljubljana: Znanstveno in publicistično središče. 
OECD (2006). Where immigrant students succeed: A comparative review of performance and engagement in Pisa 2003. Paris: OECD.

OECD (2007). PISA 2006: Science competencies for tomorrow's world. Vol. 1: Analysis. Paris: OECD.

OECD (2010a). PISA 2009 Results: Overcoming social background - equity in learning opportunities and outcomes (Volume II). Pridobljeno s http://dx.doi.org/10.1787/9789264091504-en

OECD (2010b). PISA 2009 Results: What students know and can do - Student performance in reading, mathematics and science (Volume I). Paris: OECD.

OECD (2010c). PISA 2009 results: Learning to learn - Student engagement, strategies and practices. Paris: OECD.

OECD (2011a). PISA 2009 in focus 1. Does participation in pre-primary education translate into better learning outcomes at school? Pridobljeno s http://www.oecd.org/dataoecd/17/36/47181777.pdf

OECD (2011b). Lessons from PISA for the United States: Strong performers and successful reformers in education. Paris: OECD.

OECD (2012). Starting strong III: A quality toolbox for early childhood education and care. Pridobljeno s http://dx.doi.org/10.1787/9789264123564-en

Peček Čuk, M., in Lesar, I. (2006). Kako obravnavati različne učence v osnovni šoli - dilema na formalni ravni in z vidika učiteljev. Sodobna pedagogi$k a, 57$ (posebna izdaja), 54-77.

Resman, M. (1996). Ravnatelj in motivacija učiteljev za sodelovanje in kvalitetno delo. Sodobna pedagogika, 45(5-6), 213-226.

Resman, M. (2003). Integracija/inkluzija med zamislijo in uresničevanjem. Sodobna pedagogika, 54(posebna izdaja), 64-83.

Resman, M. (2006). Oblikovanje medkulturne šolske skupnosti. Sodobna pedagogika, 57(posebna izdaja), 202-217.

Schultz, T. W. (1968). Resource for higher education: An economist's view. American Economic Review, 51(1), 1-17.

Schultz, T. W. (1971). Investment in human capital - The role of education and of research. New York, NY: The Free Press.

Skubic Ermenc, K. (2003a). Komu je namenjena medkulturna pedagogika? Sodobna pedagogika, 54(1), 44-58.

Skubic Ermenc, K. (2003b). Enakost izobraževalnih možnosti v slovenski osnovni šoli s perspektive medkulturnosti (Doktorska disertacija). Univerza v Ljubljani, Filozofska fakulteta, Ljubljana. 
Smyth, G. (2001). Odziv učiteljev na dvojezične učence v šestih osnovnih šolah na Škotskem: etnografska študija. Sodobna pedagogika, 52(2), 100-121.

Statistični urad Republike Slovenije (2010). Popis prebivalstva, gospodinjstev in stanovanj 2002. Koper: Annales.

Statistični urad Republike Slovenije (2011). Pridobljeno 27. 12. 2012, s http:// www.stat.si/

Statistični urad Republike Slovenije (2013). Pridobljeno 27. 12. 2012, s http:// www.stat.si/

Strategija vključevanja otrok, učencev in dijakov migrantov v sistem vzgoje in izobraževanja v Republiki Sloveniji (2007). Pridobljeno 6. 11. 2010 s http://www.mizks.gov.si/fileadmin/mizks.gov.si/pageuploads/podrocje/os/ devetletka/program_drugo/Smernice_izobr_otrok_tujcev_v_vrtcih

Talib, M. T. (2006). Why is it so hard to encounter Diversity. V M. T. Talib (ur.), Diversity challenge for educators (str. 139-156). Turku: Finnish Educational Research Association.

Taylor, M. (1995). Concepts-clés et bases de l'éducation interculturell‘. Tous différents, tous égaux. Kit pédagogique, 13-52.

Vah Jevšnik, M., in Toplak, K. (2011). Migracije, etnična/kulturna raznolikost in medkulturni dialog kot pomembne tematike izobraževanja za trajnostni razvoj. IB Revija, 45(1-2), 39-43.

Vehovar, U., Makarovič, M., Podgornik, N., in Černič, M. (2009). Od ekonomskega do kulturnega kapitala: izobraževalni sistem kot dejavnik socialnega izključevanja $v$ Republiki Sloveniji. Ljubljana: Založba Vega. 



\title{
Delo s starostniki
}

\author{
Andrej Berdajs \\ Univerza na Primorskem, Pedagoška fakulteta
}

\section{Staranje prebivalstva}

Fenomen staranja prebivalstva $-\mathrm{z}$ večanjem deleža starih ljudi $-\mathrm{v}$ razvitih državah poteka že desetletja. Tudi populacija starih se stara - vedno več je visoko starih ljudi. Spreminjajo se tudi razmerja med ekonomsko aktivnimi in vzdrževanimi člani družbe. Danes imamo približno $17 \%$ populacije, ki je starejša od 65 let. Demografske projekcije evropskega statističnega urada pa predvidevajo, da se bo v naslednjih desetletjih ta delež povečal na $30 \%$. Stalnica, ki jo opazimo ob pregledu statističnih podatkov o starih ljudeh, je, da ženske živijo v povprečju 10 let dlje kot moški. Pečjak (2007) ugotavlja, da je bila pred dvema desetletjema povprečna starost oskrbovancev v domovih za starejše 70 let, danes pa je 80.

M. Šircelj (2009) pravi, da se v razvitem svetu delež starega prebivalstva veča, ob tem da se veča tudi delež visoko starih. Kot vzroke za tako stanje navaja: zmanjševanje rojstev, zmanjševanje umrljivosti in selitve.

A. Sinjur (2010, str. 59) pravi, »da so selitve (migracije) zelo kompleksen globalen pojav, s katerim se srečujejo vse države po svetu. Države so tako lahko izvor migracij, prehodni cilji potovanja, mesto priselitve, po navadi celo vse troje skupaj«.

Selitve, največkrat zaradi ekonomskih in političnih vzrokov, imajo seveda dve posledici: tam, od koder se ljudje odseljujejo, to povzroča staranje populacije; na območjih, kamor se ljudje priseljujejo, pa to povzroča pomlajevanje populacije. S spreminjanjem deleža starih ljudi se spreminja tudi 
odnos do njih. Starih je bilo včasih manj, bili so deležni spoštovanja zaradi znanja in izkušenj. Danes so bolj cenjeni mlajši, ker jih je malo in se lažje prilagajajo tehnološkemu razvoju (Šircelj, 2009). Sedmak (2005) opozarja, da lahko migracije ljudi v Evropi nekaj časa amortizirajo povečevanje populacije starih in dajo možnost za odlašanje s spremembami, ki jih v organizaciji družbe ta pojav terja. Slej ko prej pa se bo potrebno soočiti z naslednjimi spremembami in dejstvi:

- podaljševanje delovne dobe (tudi zaradi lastne želje delovnih ljudi);

- vedno večji delež starejšega prebivalstva, ki ima porabniško vedenje;

- $\quad$ staranje prebivalstva ne bo prizadelo vseh držav Evropske unije v istem času;

- preprečevanje izključenosti starejših in njihovo vključevanje $\mathrm{v}$ delo ali celo zaposlitev;

- omogočiti starejšim dostop do primernih prebivališč, transportov, zdravja, oskrbe, pa tudi izobraževanja;

- prenašanje znanja za uporabo novih komunikacijskih tehnologij na starejše;

- preprečevanje revščine starejših;

- odstranjevanje zgrešenih klišejev o starosti.

Isti avtor poudarja, da je nova paradigma starosti v pravnih listinah Evropske unije naslednja: temelj je upoštevanje, da sta kakovost življenja in samostojnost mogoča $\mathrm{v}$ vseh življenjskih starostnih dobah; potrebno je preprečevati osamitev ter izključenost starejših ljudi ter krepiti njihovo samozavest; zagotavljati in ohranjati moramo sposobnost starejših za samostojno odločanje ter zagotoviti njihovo občansko in politično vlogo s participacijo v vseh javnih odločitvah.

Prebivalstvo Slovenije je v 20. stoletju naraščalo in leta 2005 preseglo 2 milijona. V demografskih projekcijah se vidi, da se bo čez dve ali tri desetletja začelo zmanjševati in bo okoli leta 2060 na ravni leta 1970. Število tujcev se bo v tem obdobju z 2 \% povečalo na 10,7 \% (Šircelj, 2009).

Poseben problem predstavlja zniževanje deleža prebivalstva, ki je delovno aktivno. Če želimo te posledice zmanjševati, bo potrebno povečati izkoriščenost tega dela populacije oziroma ga povečati na račun kasnejšega prehoda v vzdrževani del prebivalstva (upokojitev). Pečjak (2007) navaja, da čeprav upokojevanje in zdravstveni stroški za starejše ljudi že 40 let 
naraščajo, so v zadnjem obdobju začeli padati. Čedalje manj držav predpisuje obvezno upokojitev pri določeni starosti in uveljavlja se delno zaposlovanje starejših. Tako stari del populacije sam neposredno prispeva k svojemu vzdrževanju.

Tudi v družinskem okolju se spreminjajo sorodstvene mreže. Vedno več imamo sorodnikov v ravni črti (oče, mati, ded, babica) in manj v stranski črti (brat, sestra, bratranec, stric) (Šircelj, 2009).

$S$ področjem dela s starimi ljudmi se ukvarja gerontologija, ki je veda o starosti, staranju in starih ljudeh, ter gerontagogika, ki se ukvarja $\mathrm{z}$ vodenjem in vzgojo starih ljudi. Druga temelji in izhaja iz spoznanj prve. Integralna socialna gerontologija se ukvarja s spoznavanjem zakonitosti staranja in sožitja starih ljudi v okviru družbenega sistema ter $\mathrm{z}$ metodami za doseganje kakovostnega staranja ter bivanja $\mathrm{v}$ družbenem sistemu. Socialna gerontagogika pa obsega delo s posameznikom (po principu zaupnosti, intimnosti), skupinsko delo (na principu skupinskih zakonitosti in dinamike) in skupnostno delo (Ramovš, 2003). Istim vsebinam se s svojo dejavnostjo pridruži tudi socialna pedagogika.

Vse vede, ki se ukvarjajo s starostniki in rešujejo njihove probleme, se bodo morale pospešeno aktivirati in $\mathrm{z}$ upoštevanjem vseh naštetih dejstev sooblikovati družbo in mehanizme, ki bodo starejšim ljudem prijazni.

\section{Starost in staranje}

\section{Starostna obdobja}

Pečjak (2007) navaja, da se staranje začne ob oploditvi. Spremembam, ki jih imamo za staranje, lahko $\mathrm{v}$ prvi polovici človeškega življenja rečemo zorenje, $v$ drugi polovici pa staranje.

Ramovš (2003), A. Kristančič (2005) in V. Hlebec (2009) navajajo, da lahko življenjske cikluse delimo na tri obdobja: mladost (od rojstva do zaključka šolanja), srednja leta (od začetka zaposlitve do upokojitve), starost (od upokojitve do zaključka življenja).

Za obdobje starosti je značilno, da človek materialni razvoj vedno bolj prepušča mlajšim generacijam, njim pa predaja tudi svoje življenjske izkušnje.

Obdobje človekove starosti lahko definiramo tudi na naslednje načine (Ramovš, 2003): kronološka starost (glede na datum rojstva, nekateri za začetek starosti navajajo 65. leto starosti, nekateri že 6o. leto); funkcionalna starost (glede na sposobnost samostojnega opravljanja temeljnih življenj- 
skih opravil); doživljajska starost (glede na to, kako človek sprejema in doživlja svojo trenutno starost).

Čas starosti lahko bolj podrobno razdelimo na: zgodnjo starost (od 65 do 75 let, gre za obdobje, ko se ljudje privajamo na starost, smo še polno dejavni in relativno zdravi); srednjo starost (od 76 do 85 let, $v$ tem času se prilagajamo na upadanje moči in zdravja, na izgubljanje vrstnikov in tudi partnerjev); pozna starost (od 86 let naprej, tu postanemo v večji meri prejemniki pomoči in izvajamo zadnje naloge v življenju).

\section{Stereotipi o staranju}

Pečjak (2007, po Berger in Thompson, 1994) predvideva, da mlajše ljudi stik s starejšimi spominja na umrljivost in zaradi tega razvijejo različne samozaščitne mehanizme, ki se velikokrat izražajo kot stereotipi o starosti, katerih namen je potlačiti misli na starost in smrt.

Kako se nekdo odziva na proces staranja, je odvisno od prožnosti njegovih percepcij o obdobju starosti. Starost lahko interpretiramo kot temačno bodočnost ali pa jo doživljamo kot razširitev in obogatitev življenjskih možnosti (Kristančič, 2005). Avtorica navaja naslednje razloge, zaradi katerih lahko na starost gledamo negativno: pretirano poveličevanje obdobja mladosti; znamenj staranja ne dojemamo kot zorenje, ampak kot bližanje smrti; o staranju ne razmišljamo kot o procesu, ki se začne ob rojstvu, ampak pri 30 ali 40 letih.

Ta strah pred staranjem (gerontofobija) je prisoten tako pri mladih kot pri starih ljudeh. Dejstvo, ki ga morajo prevzeti vse generacije, je, da proces staranja poteka skozi vsa življenjska obdobja.

Pečjak (2007) opozarja na razširjenost ageizma - diskriminacije starostnih skupin prebivalstva. Pogost primer je prisilno upokojevanje, in sicer ne zaradi tehtnih vzrokov (sposobnosti), ampak samo zaradi koledarske starosti. Tudi pri zavarovalnicah naletimo na problem, da imajo starejši ljudje dražje zavarovalnine ali pa so jim celo onemogočene. Tudi banke odklanjajo zadolževanje starejših ljudi. Vsebine ageizma najdemo tudi v razpisih za nova delovna mesta, kjer se brez vsebinske utemeljitve favorizira mlade ljudi oziroma »a priori« odklanja starejše.

\section{Družina in star človek}

Večina ljudi preživi največji del življenja kot član družine. Družina tudi pozitivno vpliva na življenjsko dobo njenih članov. Ljudje, ki živijo v dru- 
žinah, živijo dlje kot samci in ločenci (Pečjak, 2007). Starejšim ljudem v družini vloga dedka in babice velikokrat postane glavna vsebina in smisel njihovega življenja.

Vloga družine, predvsem na področju skrbi za svoje stare člane, se s staranjem prebivalstva spreminja. Najboljša pot, da se družina na novo vlogo pripravi, je stalna in intenzivna komunikacija med njenimi člani, sobivanje in izobraževanje o vsebinah za kvalitetno preživljanje starostnega obdobja življenja (Ramovš, 2003).

Družine iz večinoma dvogeneracijskih prehajajo v trigeneracijske. $\mathrm{V}$ takih družinah je bistveno več možnosti za prenašanje življenjskih spoznanj in izkušenj starejših na mlajše, starim ljudem pa ravno to daje smisel bivanja (Kladnik, 1999).

A. Kristančič (2005) navaja, da bo moral biti odgovor na povečanje števila starih ljudi tudi redefiniranje ${ }^{\mathrm{I}}$ družine, in sicer od družine, ki smo jo poznali in je bila usmerjena predvsem k otrokom, njihovi vzgoji in njihovim potrebam, $\mathrm{k}$ tako imenovani matrični, transgeneracijski ${ }^{2}$ družini, katere usmeritev bo k njenim odraslim in starejšim članom.

Pečjak (2007) opozarja, da starejši zakonci, ki imajo po upokojitvi več časa zase in za stike drug z drugim, lahko zapadejo tudi v naveličanost in pogoste spore. Rešitev je aktivno udejstvovanje $\mathrm{v}$ različnih organizacijah za stare ljudi, ki povečajo pestrost življenja.

Dejstvo je, da tudi starejši ljudje, ki potrebujejo pomoč, kot člani družine participirajo k njenem funkcioniranju. To njihovo sodelovanje ali udeležba da starim ljudem občutek koristnosti in jim dviguje pozitivno samopodobo. Pomembno je tudi, da imajo stari ljudje v krogu družine občutek varnosti. Mlajši člani v družini pa imajo možnost učenja na podlagi prenosa izkušenj starejših. V tem sodelovanju med generacijami pride do izraza pravilo, da ima vsaka generacija več nečesa, kar drugi primanjkuje.

\section{Potrebe v starosti}

Ramovš (2003) trdi, da človek bolj ko je star in zrel, bolje prepoznava svoje potrebe, kakor tudi možnosti, ki jih ima za njihovo zadovoljevanje. Med temeljnimi potrebami izpostavlja tisto po materialni preskrbljenosti, pri kateri je pomembno, da je vir lastno delo (trenutno ali minulo) - največkrat pokojnina oziroma če je ni, socialna pomoč.

1 Ponovna določitev razmerij, pristojnosti, vrednot in prioritet.

2 Družina, ki povezuje več generacij. 
Prav tako starejši ljudje ne smejo pozabiti na ohranjanje telesne, duševne in delovne svežine (to so temeljne vrednote za doseganje kvalitetne starosti, predvsem zato, ker se naravno $\mathrm{z}$ leti zmanjšujejo; ravno zaradi tega jim je potrebno posvečati več pozornosti; stalno gibanje, zdrava prehrana, življenje s ciljem, ustvarjalno delo s harmonijo osebnega ritma; vse to da efektivne rezultate, če je nastavek postavljen $\mathrm{v}$ prejšnjih življenjskih obdobjih).

Potreba po soljudeh je važna v vseh življenjskih obdobjih, njen pomen pa še poraste v starosti. Star človek še bolj potrebuje osebni stik s človekom, ki ga ima za svojega. Prav tako je nezanemarljiv osebni, kožni kontakt z bližnjo osebo. Osamljenost je predvsem v starosti lahko najhujša stiska, zato so pravočasne aktivnosti za ohranjanje in obnavljanje socialne mreže ena od poglavitnih nalog v vseh življenjskih obdobjih.

Prav tako je staremu človeku v večji meri kot mlademu pomembno predajanje življenjskih izkušenj in spoznanj mlajšim generacijam. To je osnovno dejstvo, na podlagi katerega star človek svoje življenje dojema kot nekaj vrednega. Ugotovljena je neposredna povezava med lastnim sprejemanjem novih znanj in spoznanj in med dajanjem svojih izkušenj drugim.

Dojemanje pomena vseživljenjskega učenja je pomembno, tako na področju intelektualnega izobraževanja kot socialnega učenja. Na podlagi novih možnosti v percepcijah sveta in soljudi, stari ljudje okrepijo potrebe po doživljanju smisla lastnega življenja.

Sprejemanje človeške onemoglosti tako s strani starega človeka kot tudi s strani svojcev ali negovalcev je pogoj, da si star človek dopusti predstavo, da je oslabljen in potreben pomoči. Potreba po negi ob onemoglosti ne sme biti razlog za zapiranje pred ljudmi in beg v osamljenost.

Omeniti velja tudi potrebo po nesmrtnosti. To, da se bodo potomci človeka spominjali (grob), da bodo ostala njegova realizirana dela, marsikomu pomeni važno motivacijo. Do neke mere (ali tudi v celoti) jo lahko zamenja vera $\mathrm{v}$ življenje po smrti.

Zavedanje vsebine potreb starega človeka mora biti osnova za usmerjanje dejavnosti in predvsem vzpostavljanje medčloveških odnosov v prejšnjih obdobjih življenja. A. Kristančič navaja (2005), da ima vsaka generacija, ki se postara, povsem drugačne potrebe, zmožnosti, sposobnosti in cilje.

Eden od faktorjev, ki pripomorejo k bistvenemu zvečanju možnosti za kvalitetno staranje, je izobraževanje starejših. Jelenc Krašovec in Kump (2009) omenjata naslednje razloge za motivacijo starih ljudi za izobraževanje: sociološke razloge (izobraževali so se že v mladosti, želijo zapolniti 
svoj prosti čas); psihološke razloge (temeljijo na osebnih značilnostih posameznika in njegovih kognitivnih zmožnostih) ter ekonomske razloge (pri teh je važno, da stroški izobraževanja ne smejo biti ovira). Kot najpomembnejši razlog, da se starejši ljudje vključijo v izobraževalne procese, se pokaže izobraževanje, ki so ga posamezniki že opravili v mladosti.

\section{Kakovostna starost}

Starost - tretje življenjsko obdobje - je čas, ko lahko človek družbi in bližnjim vrača znanje, svoje vire in izkušnje, ki jih je nabral skozi lastne življenjske dogodke. Tendenca starih ljudi mora biti kakovostno preživetje obdobja starosti, ne kot doživljanje nečesa neprijetnega. Dojemanja starosti večinoma izhajajo iz izkušenj, ko ljudje opazujemo stare ljudi in za nekoga zaključimo, da je (ali ni) tak, kot se nam zdi, da bi bilo idealno.

Preseči moramo stereotipno dojemanje starosti. Izhodišča za kakovostno preživljanje starosti temeljijo na doseganju osebne povezanosti med mlado, srednjo in staro generacijo, na tem, da stara generacija sprejema svoje obdobje in da se že srednje generacije pripravljajo na starost. Ob tem moramo preprečiti marginalizacijo starosti in doseči, da se družba v celoti pripravlja na povečanje deleža stare generacije (Ramovš, 2003).

Isti avtor tudi opozarja, da morajo stari ljudje preseči strah pred starostjo, ne smejo si pa zakrivati oči pred neizbežnimi dejstvi, kot so različni problemi, ki izhajajo iz pokojninskega sistema, ki ne pušča pretirano veliko prostora za različne aktivnosti večini starostnikov. Te stvari je potrebno sprejeti in najti poti ter načine, kako z njimi kljub vsemu živeti. Sprejetje starosti mora biti zavestna odločitev. Vsak posameznik si mora najti primeren način staranja na podlagi lastnih intelektualnih in emocionalnih zavedanj. Vsak si mora s pomočjo doživljajskega (vzori, meditacija ipd.) in socialnega (skupine, komunikacija ipd.) učenja najti svoj način bivanja $\mathrm{v}$ obdobju starosti in svoj prostor pod soncem.

A. Kristančič (2005) pa pravi, da moramo na dejstvo, da se življenjska doba ljudi daljša, odgovoriti z naslednjimi aktivnostmi: odpraviti moramo strah pred staranjem; premočrtno življenjsko načrtovanje moramo zamenjati s cikličnim; ustvariti je potrebno nove oblike družinskih odnosov (glede na vedno večji razpon generacij, ki v nekem trenutku sobiva); zmanjšati je potrebno pogostnost kroničnih bolezni v visoki starosti; prav tako moramo organizirati dejavnosti, ki bodo starejšim ljudem omogočala udobje, zadovoljstvo in bodo ustrezala njihovim zmožnostim ter s sožitjem generacij ustvariti socialni sistem, ki bo za vse pravičen. 
Ista avtorica kot zelo pomembno komponento izpostavlja še načrtovanje življenja posameznika in dogodkov v njem. Staro, tradicionalno linearno načrtovanje življenja je bilo predvidljivo: $\mathrm{v}$ določenem starostnem obdobju je bil čas za točno določene dejavnosti in dogodke (šolanje, delo, poroka, družina ipd.). Podaljševanje življenja in daljše ohranjanje vitalnosti pa terja ciklično načrtovanje življenjskih aktivnosti in dogodkov. Elementi življenjskih obdobij, kot so družina, izobraževanje, delo, rekreacija, prosti čas, prostovoljno delo, se prepletajo pri vsakem človeku tako, da doseže ubranost s samim seboj v odvisnosti od svojega temperamenta in zmožnosti. S tem vsak doseže večjo kvaliteto življenja. Še posebej to velja za drugo polovico življenjskega obdobja.

Nujno je, da vsak človek utrjuje in sprejema svojo samopodobo v zrelih letih ter da sprejema spremembe lastnega telesa. Starost je življenjsko obdobje, ki je seveda različno od mladosti in srednjih let, ni pa manj vredno in manj smiselno.

Človek mora že v obdobju srednjih let začeti aktivnosti, s katerimi nadaljuje tudi, ko vstopi v obdobje starosti. Ramovš (2003) opozarja, da mora biti pozoren predvsem na naslednja področja: na vzpostavitev povezave med vsemi tremi generacijami (mlado, srednjo in staro); na konstantno skrb za zdravo življenje in zdravje; na skrb za ohranjanje in krepitev osebne svobode in samostojnosti odločanja; na ohranjanje in krepitev medčloveških odnosov $\mathrm{z}$ različnimi ljudmi; na konstantno učenje novih dejstev in spretnosti ter ustvarjalnost ter na zavedanje vrednosti in smisla preteklosti, sedanjosti in prihodnosti svojega življenja.

Ramovš kot življenjske naloge, ki si jih mora zastaviti star človek s ciljem, da bo doživel kvalitetno starost, našteva naslednje: dejavno življenje (stalno ohranjanje telesne, duševne in delovne svežine ter povezanostmi z ljudmi); preprosto življenje (umirjene aktivnosti, večja osebna svoboda pri njihovem načrtovanju, prepuščanje skrbi za materialno preskrbo srednji generaciji); sproščeno življenje (sprejeti je potrebno smiselno stališče do preteklosti, sedanjosti in prihodnosti); vedro življenje (z nadaljevanjem vseživljenjskega učenja in predajanjem življenjskih izkušenj mlajšim); samostojno življenje (predvsem po izgubi življenjskih sopotnikov) in dozorelo življenje (opravljanje zadnjih življenjskih nalog).

\section{Socialne mreže $v$ starosti}

V vseh življenjskih obdobjih, še bolj pa v starosti, je pomembna človekova vpetost v socialno mrežo, kakor tudi doživljanje lastne osebne intimnosti (Ramovš, 2003). 
Socialna omrežja so pomemben dejavnik zdravja (ne le starejših ljudi). Zlasti je pomembna stalna socialna opora, ki omogoča posamezniku občutek pripadnosti in intimnosti. Ta se realizira večinoma s partnerjem, $\mathrm{z}$ drugimi družinskimi člani, s sosedi, s člani skupnosti ali s člani organizacije, $v$ katero se posameznik vključuje (Pahor, Domanjko in Hlebec, 2009).

Socialna opora je največji blažilec vseh življenjskih stresnih dogajanj. Njeno pomanjkanje ali celo popolna odsotnost vedno vodi v depresijo in je razlog zanjo. Pomen medčloveških odnosov za vsakega v vseh življenjskih obdobjih (še bolj pa v starosti) je neprecenljiv. Partnerski odnosi, ljubezen in intimnost so bistveni faktorji, ki vplivajo na kvaliteto življenja, predvsem pa nam pomagajo premagovati različne ovire in težave $\mathrm{v}$ vseh življenjskih obdobjih.

Kladnik (1999) navaja, da v socialnih mrežah sicer prevladujejo funkcionalni odnosi. Bistveno bolj pa socialni stiki zadovoljijo človeka, če gre za temeljni odnos z neko osebo, kar omogoča občutek varnosti. Poglobljeni odnosi omogočajo spontanost in so osnova za socialno učenje.

Pomembne so vezi ne le $\mathrm{v}$ isti generaciji, ampak tudi tako imenovana generacijska zavezništva, kjer se tkejo vezi med zastopniki različnih generacij s ciljem, da lahko ena generacija prevzame odgovornosti in skrbi za druge generacije. Vse tri generacije (mlada, srednja in stara) so sistemska celota in so v stalni komplementarnosti (Ramovš, 2003). Avtor opozarja na pomen medgeneracijskega sodelovanja in programov, ki bodo pomagali konstruirati kvaliteten sistem za življenje starih ljudi. Sem sodi ozaveščanje prebivalstva o pomenu in komponentah kakovostnega staranja in nujnosti priprave na starost $\mathrm{v}$ prejšnjih življenjskih obdobjih, usposabljanje za čas po upokojitvi, usposabljanje družin, v katerih živijo stari ljudje, ter usposabljanje starejših za boljše razumevanje mlajših.

A. Kristančič (2005) poudarja, da mora vpetost v socialno omrežje in ohranjanje stikov vsak posameznik planirati in izvajati aktivnosti skozi celotno življenjsko obdobje. Važno je obvladovanje komunikacije (tako $\mathrm{z}$ drugimi kot s samim seboj). Pomembna je stalna notranja komunikacija posameznika in samoevalvacija aktivnosti in razmišljanj. Nezanemarljiv element dobre in kvalitetne komunikacije je dobro poslušanje in slišanje.

Ramovš (2003) opozarja na socialne motnje, na katere naletimo pri starih ljudeh. To so velikokrat pretirana črnogledost, zagrenjenost in sitnoba. S strani bližnjih ali oseb, ki skrbijo za starega človeka, jih je potrebno sprejeti in jih blažiti s pravilno komunikacijo. Nasploh je vedno najboljše 
za preprečevanje in blaženje socialnih motenj v starosti dobra, po možnosti medgeneracijska, komunikacija.

Starost in staranje sta kategoriji, ki ju je potrebno upoštevati kot sestavna dela življenja slehernika. S splošnim vedenjem o osnovnih zakonitostih tega življenjskega obdobja bomo lahko bistveno zmanjšali (ali izkoreninili) v družbi zasidrane stereotipe o staranju. Lahko bomo redefinirali družino kot najbolj aktivno osnovno celico za družbeno integracijo starostnikov. Upoštevanje potreb starejših ljudi ter predvsem omogočanje njihovega vpetja v socialne mreže so temelj za kakovostno starost.

\section{Obravnava starostništva in institucije za socialno varstvo} starejših ljudi

Temeljno poslanstvo države je med drugim organiziranje socialne politike. Zaradi omenjenega dejstva, da se delež starih ljudi v družbi povečuje, mora država krepiti pogoje, $s$ katerimi bo ta del populacije imel možnosti, da obdobje starostništva kvalitetno preživi in da ob tem tudi družbi in mlajšim generacijam uspešno predaja svoje bogate življenjske izkušnje.

V Sloveniji se je relativno zgodaj, že leta 1963, začela znanstvena obravnava staranja ljudi. Takrat je bil ustanovljen Gerontološki inštitut. Žal se je v kasnejšem obdobju v prejšnji državi dejavnost zožila le na področje geriatrije (medicinske obravnave starostnih težav), ki se je kasneje še reduciralo na obravnavo bolezni srca in ožilja (Sedmak, 2005).

Cilj današnjih aktivnosti v politiki socialnega varstva starih ljudi ni le podaljševanje življenjske dobe, ampak podpiranje kakovosti v tem življenjskem obdobju. S tem ciljem je bila ustanovljena Univerza za tretje življenjsko obdobje in organizirala se je oskrba za stare ljudi na domu.

Da omogoči starim ljudem možnosti kakovostnega staranja, mora država kot nosilka socialne politike poskrbeti predvsem za naslednje programe in konkretne vsebine v socialnih mrežah (Ramovš, 2003):

- programi za kakovostno življenje samostojnih starejših ljudi,

- programi za delno pomoč starejšim ljudem,

- programi za popolno pomoč opešanim starejšim ljudem.

Izvedba teh programov je možna na naslednje načine:

- javni državni programi in državna podpora družinam, ki skrbijo za stare ljudi, ter državna podpora civilnim programom,

- civilni in zasebni neprofitni - prostovoljni programi, 
- tržni programi.

M. Nagode (2009) navaja, da je v Sloveniji v trenutnem modelu skrbi za stare ljudi država obdržala dominanten položaj kot financer izvajanja različnih oblik oskrbe, ne pa kot izvajalec. Poleg države se kot ustanovitelji institucij za varstvo in oskrbo starih ljudi pojavljajo tudi zasebne neprofitne organizacije (največ cerkev), pa tudi zasebne profitne organizacije. Veliko jih ima $\mathrm{z}$ državo sklenjeno koncesijsko pogodbo, kar lahko neposredno vpliva na konstantnost in strokovnost njihovega delovanja.

V domovih za ostarele je trenutno manj kot tretjina starih ljudi, ki potrebujejo pomoč. Povečuje se organiziranost in ponudba vsebin za stare ljudi s strani civilne družbe. To so različna društva za aktivnosti starih ljudi, veliko je tudi samoorganiziranja starejših v svoje lastne organizacije, v porastu je organiziranje mreže za medgeneracijsko sožitje.

Pri oskrbi starih ljudi je potrebno upoštevati, da so zelo heterogena skupina ljudi. Sestavljajo jo lahko starejši toda relativno sposobni, tisti z manjšimi ali večjimi zdravstvenimi težavami, dementni, invalidi, tujci ipd. (Mali, 2008).

V. Miloševič Arnold (200o) povzema najpomembnejša izhodišča za sestavo konceptov uspešnega dela s starimi ljudmi:

- razumevanje razvojnih faz staranja,

- upoštevanje življenjskih izkušenj in vlog, ki so jih doživeli stari ljudje,

- razumevanje perspektiv starih ljudi,

- ugotavljanje in upoštevanje funkcionalnih sposobnosti starih ljudi,

- $\quad$ poznavanje njihove dinamike v družinskem življenju,

- prepoznavanje njihovih potreb,

- zmožnost komuniciranja v govorici starejših,

- trdno prepričanje v neodvisnost starih ljudi,

- razumevanje smrti in umiranja.

Na teh izhodiščih morajo temeljiti vse sistemske in zakonodajne rešitve, ki jih bo družba sprejela, da bo ne samo omogočila, ampak tudi izboljšala socialno varstvo za starejše ljudi. 


\section{Oblike socialnega varstva starejših ljudi}

J. Mali (2009) navaja, da za Slovenijo po tradiciji velja, da je na področju varstva starejših zanjo značilna institucionalna skrb za stare ljudi - domovi za starejše. Po letu 2000 se v organizaciji domov za ostarele doktrina od izrazito medicinskega modela oskrbe premakne v socialni model s poudarjenim individualnim pristopom do posameznika. Toda trenutna utečena praksa oskrbe $\mathrm{v}$ domovih za starejše je prilagojena starim bolnim ljudem. Stanovalci so definirani kot pasivni prejemniki pomoči (za njih se praviloma uporablja poimenovanje pacienti).

Pečjak (2007) opozarja, da se stari ljudje zelo težko prilagajajo spremembam. Preselitev v dom za stare ljudi pa to nedvomno je. Težko se privadijo na veliko število starih ljudi na enem mestu, na pomanjkanje možnosti biti sami ali vzpostaviti pristne medosebne stike $\mathrm{z}$ drugimi prebivalci $\mathrm{v}$ domu.

S predlagano zakonodajo, tudi po zgledu ostalih držav Evropske unije, naj bi v prihodnje oskrbo v domovih za ostarele izrazito diferencirali na specializirane domove za oskrbo starih ljudi, ki potrebujejo zdravstveno nego, na domove za oskrbo starih ljudi z demenco ter na domove za oskrbo starih ljudi, ki so samostojni in si želijo ter potrebujejo zgolj družabništvo.

Splošnih domov za ostarele, kot jih večinoma poznamo danes, v prihodnje naj ne bi bilo.

V privatni sferi na področju institucionalnega varstva starejših ljudi se poudarja žal le materialni standard oskrbe in ni poudarka na drugih komponentah kvalitete življenja (Mali, 2009).

Poleg oskrbe v domovih za ostarele je socialno varstvo za stare ljudi pri nas organizirano tudi v naslednjih oblikah: pomoč na domu; družinska oskrba starejših družinskih članov; pomoč starim ljudem na daljavo in dnevni centri.

Tudi tu je vključena država, ki podpira razvoj institucionalne mreže, dnevnih centrov in pomoči na domu. Pomoč je sistemsko regulirana in ima naslednje značilnosti (Nagode, 2009):

- varnost (predvidljivost, zanesljivost reagiranja),

- sociabilnost (domačnost, zaupanje, empatija in enakost $v$ odnosih),

- ekonomičnost (cenovna sprejemljivost storitev).

Pomembno je, da je pomoč profesionalna in da jo izvajajo strokovno usposobljene osebe. Ugodno je tudi, da so te komponente pomoči sta- 
rim ljudem komplementarne neformalni pomoči s strani družine, prijateljev in prostovoljcev. Ramovš (2003) kot možne organizacijske oblike navaja naslednje vrste pomoči starim ljudem: pomoč in nega na domu, pomoč družinam, ki skrbijo za svojega ostarelega člana, varovana in prilagojena stanovanja, dnevno varstvo za stare ljudi, gerontološki centri, pomoč pri samostojnosti starega človeka s tehničnimi pripomočki, domovi za stare ljudi, stanovanjske skupine za stare ljudi in oskrbniške družine.

Za doseganje ciljev zastavljenih za kvalitetno starost pa omenja naslednje programe:

- $\quad$ starostna pokojnina;

- programi za samostojne stare ljudi (zaposlitev in delo za starejše, medsebojno povezovanje starostnikov, izobraževanje za stare ljudi, šport in rekreacija, potovanja, počitnice in razvedrila, medgeneracijski projekti, priprava na upokojitev, stanovanjske skupine);

- $\quad$ pomoč na domu za delno samostojne stare ljudi (usposabljanje za člane družin s starejšim članom, pomoč in nega na domu, preprečevanje nasilja nad starimi ljudmi - zagovorništvo, pomoč na daljavo (pošta, elektronska pošta, telefon), varovana stanovanja);

- programi za popolno oskrbo (domovi za stare ljudi, oskrbniške družine, dnevno varstvo, hišne skupnosti);

- $\quad$ programi za pomoč ljudem v sklepni fazi življenja;

- programi za ozaveščanje prebivalstva o kakovostnem staranju.

\section{Pomoč starim ljudem na domu}

Kot smo že omenili, je cilj socialne politike Evropske unije ustvariti pogoje, da bi se čim večjemu številu starih ljudi omogočilo, da čim dlje v obdobje starosti ostanejo v domačem, če se le da, v družinskem okolju. Seveda morajo biti ustvarjeni pogoji, ki jim bodo nudili to tako, da bodo v čim večji meri samostojni, varni in da bo njihovo življenje kakovostno.

Pomoč na domu je temeljna socialno varstvena storitev, ki jo mora po veljavni zakonodaji organizirati občina in finančno pokriti vsaj polovico stroškov.

$\mathrm{V}$ večini to pomoč izvajajo centri za socialno delo in domovi za starejše, nekaj pa je tudi profitnih organizacij s koncesijo. Pomoč na domu obsega pomoč pri temeljnih dnevnih opravilih, gospodinjsko pomoč in pomoč pri ohranjanju socialnih stikov. 


\section{Družinska oskrba starejših družinskih članov}

V družinah so oskrbovalci starih družinskih članov predvsem osebe, ki so sorodstveno povezane z osebo, ki jo oskrbujejo. Lahko (večinoma) prebivajo na skupnem naslovu ali pa drugje. Praviloma so to osebe, ki nimajo formalno pridobljene izobrazbe ali znanj s področja oskrbe starejših ljudi. Seveda je v veliki večini primerov taka oskrba brezplačna.

S. Hvalič Touzery (2009) povzema, da tako oskrbo sestavljajo: nega, pomoč pri ohranjanju in vzpostavljanju socialnih stikov ter gospodinjska pomoč.

Družinska oskrba starih družinskih članov je lahko pomemben vidik družinskega življenja, ki da možnost, da pri njej sodeluje več družinskih članov različnih generacij. S. Hvalič Touzery (2009) navaja, da med družinskimi člani, ki izvajajo družinsko oskrbo, prevladujejo osebe ženskega spola (približno dve tretjini) ter da se na ta način v Sloveniji oskrbuje več starih ljudi, kot jih je oskrbovanih $\mathrm{v}$ ustanovah in različnih programih javne mreže.

Najpomembnejši razlogi, da se ljudje odločijo za vlogo oskrbovalcev starih ljudi, so čustvene vezi, občutek dolžnosti in moralna odgovornost. Materialne ugodnosti praviloma niso razlog za take odločitve (Hvalič Touzery, 2009).

Izvajanje družinske oskrbe za starega družinskega člana ima lahko za družino in oskrbovalca tako pozitivne kot negativne posledice. Med pozitivne štejejo povečanje medsebojne povezanosti, večanje občutka varnosti, rast strpnosti in odkrivanje novih notranjih moči pri posameznikih, med negativnimi pa lahko omenimo časovno stisko vsakdanjega življenja, preobremenjenost posameznih družinskih članov, ki lahko vodi v konflikte znotraj družine.

S. Hvalič Touzery (2009) navaja, da so oskrbovalci, ki skrbijo za stare ljudi v krogu družine, izrazili tudi probleme, s katerimi se soočajo, in sicer: zmanjšanje možnosti ali celo popolnoma nemogoče najti čas za lasten oddih ali dopust, pomanjkanje možnosti pridobiti svetovanje s strani strokovnjakov ter da se velikokrat oskrba reducira na eno samo osebo, ki pogreša pomoč ostalih sorodnikov.

V strategiji razvoja socialne politike v državah Evropske unije je tendenca, da bi čim večje število starih ljudi dobilo oskrbo na domu. Ob tem je nujno predvideti in realizirati strokovno in sprotno pomoč ter svetovanje družinam, ki tako oskrbo izvajajo ali se pripravljajo nanjo. 


\section{Pomoč starim ljudem na daljavo}

Pomoč starim ljudem na daljavo izvajajo predvsem centri za pomoč. Temelji na telekomunikacijski povezavi med starim človekom in centrom, in sicer kot enosmerni alarm, ki ga sproži star človek ob stiski, ali pa kot dvosmerna telefonska linija, ki omogoča komuniciranje med starim človekom in uslužbencem centra.

\section{Dnevni centri}

Dnevni centri so namenjeni starim ljudem, ki zaradi različnih razlogov potrebujejo pomoč, varovanje ali nadzor. Njihova sposobnost samostojnosti in zdravstveno stanje pa nista tako okrnjena, da bi potrebovali stalno oskrbo in zdravstveno nego. $\mathrm{V}$ dnevnih centrih imajo stari ljudje možnost komunikacije $\mathrm{z}$ vrstniki ali zaposlenimi (prostovoljci) in se vključijo $\mathrm{v}$ različne rekreacijske ali kulturne aktivnosti. Večinoma so organizirani v okviru domov za stare ljudi. Dnevni centri so velikokrat dober komplement družinski oskrbi starih ljudi, saj omogočajo občasno razbremenitev drugih družinskih članov.

V različnih oblikah socialnega varstva starejših ljudi je v naši družbi še kar nekaj rezerv. Morda je tu marsikje možnost za nove podjetniške spodbude strokovnjakov, nova zaposlovanja in ne nazadnje tudi možnosti za aktivno dejavnost zmožnih starejših ljudi.

\section{Vloga socialne pedagogike pri delu s starejšimi ljudmi}

Cilj vseh socialnopedagoških intervencij je nuditi pomoč ljudem različnih starosti v razvojnih krizah ter konfliktih, stresnih in življenjsko obremenjujočih situacijah s ciljem, da se integrirajo $v$ socialno okolje s pomočjo pedagoških pristopov, metod in strategij (Skalar, 2006).

Socialna pedagogika je usmerjena $\mathrm{k}$ reševanju problemov, ki nastajajo v vseh življenjskih obdobjih. Predvsem se usmerja na tiste dele prebivalstva, ki jim lahko pomaga pri integraciji v družbo. Rast deleža starejših ljudi nas začenja usmerjati tudi k delu $\mathrm{z}$ njimi.

Socialnopedagoško delo s starimi ljudmi vsebuje:

- pomoč tistim, ki nimajo zadosti osebnih in materialnih sredstev za upravljanje $\mathrm{z}$ življenjem;

- pomoč tistim, ki so v kritičnem obdobju življenja;

- aktivnosti, ki povečujejo klientove možnosti. 
$\mathrm{V}$ socialnopedagoškem delu delujemo preventivno, kompenzatorno, razvojno in integrativno. Vedno moramo upoštevati življenjsko okolje oseb, s katerimi delamo. Temelj socialnopedagoškega delovanja je osebni odnos s »klientom«. Na ta odnos vplivamo s svojo osebnostjo in usposobljenostjo. Pri socialnopedagoškem delu vedno izhajamo iz posameznika in njegovega socialnega okolja - tudi naše delovanje je usmerjeno tako, da bo »klient« obvladoval življenjske probleme v lastnem življenjskem kontekstu.

Cilji delovanja in interveniranja socialnih pedagogov so, da ljudem, ki jih v različnih življenjskih obdobjih bremenijo in ovirajo različne krize ter problemi, nudijo pomoč za reševanje takih situacij in jim pomagajo pri uspešni integraciji v njihovo socialno okolje. Socialni pedagog mora biti vedno odprt za socialno učenje, za reflektiranje lastnega dela in mora stalno razvijati lastno občutljivost za socialna dogajanja.

Razlogi za usmeritev delovanja socialnih pedagogov na področje dela s starejšimi, če jih še enkrat povzamemo, so naslednji:

- $\quad$ povečevanje deleža te populacije v družbi;

- $\quad$ porast stisk in patologije, vezane na starostniško obdobje ljudi;

- potrebe po učenju starejše populacije za lažje (ali sploh) dojemanje aktualnega sveta in odnosov v družbi.

V Etičnem kodeksu delavcev na področju socialne pedagogike (2006) je poudarjeno, da socialni pedagogi izhajamo iz specifik posameznika, prizadevamo si za njegovo vključevanje v okolje, ga opolnomočimo in usmerjamo $\mathrm{k}$ polnejšemu uresničevanju njegovih potreb in razvoju njegovih potencialov.

Delo socialnega pedagoga temelji na osebnem odnosu do obravnavane osebe. Le tako dobimo možnost, da vzpostavimo medij, ki omogoča vplivanje in učenje.

Vse našteto vodi $\mathrm{k}$ temu, da se socialni pedagogi aktivno vključimo kot členi verige, ki prispeva h kvalitetnemu življenju starejših ljudi. Lahko smo tvorci in vzdrževalci socialnih mrež za starejše ljudi in predvsem tisti, ki bomo ciljne skupine ozaveščali o pomenu in nujnosti takih mrež. Tudi $\mathrm{v}$ domovih za starejše je ravno socialni pedagog tista oseba, ki bo usmerjenost oskrbe za stare ljudi od izrazito medicinskega modela premaknila na bolj socialno področje. Enako velja za stanovanjske skupine, pomoč starim ljudem na daljavo ter za delovanja v dnevnih centrih za stare ljudi. 
Delo socialnega pedagoga $\mathrm{v}$ domu za starejše ljudi temelji na empatiji, razumevanju in posluhu za specifične probleme starih ljudi ter obsega (Anzeljc, 2012):

- pomoč pri vključevanju v domsko življenje;

- pomoč pri spoznavanju sostanovalcev, osebja in načina življenja ter delovanja doma;

- oblikovanje in ponudba različnih možnosti za participacijo, aktivno udejstvovanje in vpetje v socialne mreže;

- $\quad$ spodbujanje in pomoč pri vključevanju $\mathrm{v}$ domske aktivnosti in povezovanja $\mathrm{z}$ drugimi starostniki;

- oblikovanje možnosti, da se stari ljudje počutijo vredne in koristne;

- povezovanje med starimi ljudmi in svojci;

- $\quad$ pomoč pri vzpostavitvi poznanstev med sostanovalci;

- povezovanje med različnimi socialnimi mrežami (medgeneracijsko sodelovanje);

- $\quad$ biti za stare ljudi tisti, ki je pripravljen poslušati, svetovati in pomagati;

- povezovanje institucije in lokalne skupnosti;

- $\quad$ spodbujanje za udejstvovanje, ki prinese občutek sprejetosti in pripadnosti;

- koordiniranje dela prostovoljcev.

$\mathrm{V}$ enakem smislu je delo socialnega pedagoga orientirano tudi v drugih oblikah pomoči starim ljudem. To omogoča širitev socialnopedagoške paradigme tudi na področja, kjer je do sedaj bila $\mathrm{v}$ manjšini in kjer se $\mathrm{v}$ ne tako daljni prihodnosti odpirajo velike možnosti.

\section{Sklep}

Glede na trenutno stanje naraščanja deleža starih ljudi v družbi, predvsem pa na osnovi demografskih projekcij, ugotavljamo, da bo uspešno delo $s$ starimi ljudmi temelj pri zagotavljanju družbene stabilnosti. Zmanjševanje deleža aktivnega prebivalstva in povečevanje deleža vzdrževanih, višanje starosti za upokojitev, povečevanje delnega zaposlovanja starejših v organizacijo družbe postavlja nova razmerja.

Osnovno izhodišče za boljše in uspešnejše delovanje s starejšimi je bolj poglobljeno vedenje in znanje o različnih možnostih staranja, ki ga morajo 
pridobiti vsi, ki se s tem področjem ukvarjajo. V družbi je potrebno preseči zakoreninjene stereotipe o starosti in o starih ljudeh.

Razumeti moramo, kaj porast deleža starejših pomeni za funkcioniranje družin, ki se iz dvogeneracijskih spreminjajo v trigeneracijske.

Ugotavljamo, da moramo poznati in se zavedati potreb, ki se pojavljajo pri starejših ljudeh in ki so osnova za usmerjanje aktivnosti pri delu s to populacijo. Pri tem moramo izhajati iz vsebin, ki omogočajo starejšim ljudem kvalitetno preživljanje tega življenjskega obdobja.

Starejši ljudje, kot tudi tisti, ki jim pomagajo, morajo biti pozorni predvsem na ohranjanje in razširjanje socialnih mrež, v katere so vpeti posamezniki. Te mreže so pomemben dejavnik zdravja in blažilec različnih življenjskih dogajanj. Pomembne so tako v povezavah oseb istih generacij kot tudi za medgeneracijsko sodelovanje.

Država kot nosilka socialne politike mora $\mathrm{v}$ omogočanju javnih in zasebnih programov ter $\mathrm{v}$ snovanju aktualnih zakonskih okvirov najti odgovore na te razmere in omogočiti razvoj obstoječega sistema.

Bistveni cilj dela s starejšimi ljudmi je povečevanje njihove zmožnosti in sposobnosti za soočanje s težavami, ki se pojavijo v starosti, in uspešno premagovanje problemov.

Zaključujemo, da se lahko konkretno socialnopedagoško delo za starejše realizira tako $\mathrm{v}$ obstoječih institucijah kot v obliki lastne podjetniške iniciative. Pomembno je, da v socialnopedagoške izobraževalne programe vključujemo čim več vsebin, ki so neposredno povezane $z$ delom s starejšimi ljudmi. Hkrati je potrebno ozaveščanje tako socialnih pedagogov kot širše družbe, da sta socialna pedagogika in pomoč ljudem v obdobju starosti kompatibilna.

\section{Literatura}

Anzeljc, N. (2012). Socialne mreže starostnikov in vloga socialnega pedagoga $v$ institucionalnem varstvu (Diplomsko delo). Univerza v Ljubljani, Pedagoška fakulteta, Ljubljana.

Etični kodeks delavcev na področju socialne pedagogike. (2006). V B. Dekleva,

A. Kobolt, Š. Razpotnik, M. Sande, D. Zorc-Maver (ur.), Socialna pedagogika-izbrani koncepti stroke (str. 191-196). Ljubljana: Pedagoška fakulteta. Hlebec, V. (2009). Starejši ljudje v družbi sprememb. Maribor: Aristej. 
Hvalič Touzery, S. (2009). Družinska oskrba bolnih starih družinskih članov. V V. Hlebec (ur.) Starejši ljudje v družbi sprememb (str. 102-124). Maribor: Aristej.

Jelenc Krašovec, S., in Kump, S. (2009). Udeležba starejših odraslih v izobraževanju v Sloveniji. V V. Hlebec (ur.), Starejši ljudje v družbi sprememb (str. 203-220). Maribor: Aristej.

Kladnik, T. (1999). Socialna gerontologija in gerontagogika. Socialna pedagogi$k a, 3(2)$, str. 185-194.

Kristančič, A. (2005). Nova podoba staranja - siva revolucija. Ljubljana: AA Inserco.

Mali, J. (2008). Od hiralnic do domov za stare ljudi. Ljubljana: Fakulteta za socialno delo.

Mali, J. (2009). Spremembe v institucionalnem varstvu starejših. V V. Hlebec (ur.), Starejši ljudje v družbi sprememb (str. 95-108). Maribor: Aristej.

Miloševič Arnold, V. (200o). Profesionalne vloge socialnih delavcev pri delu s starimi ljudmi. Socialno delo, 39(4-5), str. 253-263. Ljubljana: Fakulteta za socialno delo.

Nagode, M. (2009). Organizirana pomoč za stare ljudi, ki živijo na domu: pomoč na domu in varovanje na daljavo. V V. Hlebec (ur.), Starejši ljudje v družbi sprememb (str. 125-138). Maribor: Aristej.

Pahor, M., Domajnko, B., in Hlebec, V. (2009). Spleti zdravja in bolezni: socialna omrežja starejših kot dejavnik zdravja. V V. Hlebec (ur.), Starejši ljudje v družbi sprememb (str. 221-236). Maribor: Aristej.

Pečjak, V. (2007).Fn Psihologija staranja. Bled: samozaložba.

Ramovš, J. (2003). Kakovostna starost. Socialna gerontologija in gerontagogika. Ljubljana: Inštitut Antona Trstenjaka.

Sedmak, M. (2005). Posameznik družba - država - Evropa. V A. Kristančič (ur.), Nova podoba staranja - siva revolucija (str. 197-217). Ljubljana: AA Inserco.

Sinjur, A. (2010). Učenci z imigrantskim ozadjem - politike in praksa učenja maternega jezika učencev imigrantov v nekaterih državah EU. Educa, 19(3-4), 59-69.

Skalar, V. (2006). Štiri desetletja do socialne pedagogike. V B. Dekleva, A. Kobolt, Š. Razpotnik, M. Sande, D. Zorc - Maver (ur.), Socialna pedagogika-izbrani koncepti stroke (str. 191-196). Ljubljana: Pedagoška fakulteta.

Šircelj, M. (2009). Staranje prebivalstva v Sloveniji. V V. Hlebec (ur.), Starejši ljudje v družbi sprememb (str. 15-44). Maribor: Aristej. 



\title{
Doživljajska pedagogika v Sloveniji skozi teorijo in prakso
}

\author{
Mitja Krajnčan in Damjan Habe \\ Univerza na Primorskem, Pedagoška fakulteta \\ Mladinski dom Jarše, Ljubljana \\ Univerza na Primorskem, Pedagoška fakulteta
}

\section{Uvod v teorijo doživljajske pedagogike}

Doživljajsko pedagogiko pojmujemo kot metodo vzgojno-izobraževalnega dela, kot učno metodo ali kot vzgojni ukrep. Njen imanentni cilj je vzgoja. Temelji na celostnem pristopu, ki ne izključuje nobene bistvene komponente človeškega bitja in se lahko $\mathrm{v}$ grobem naslovi s srcem, glavo in rokami. Torej ne favorizira kognitivne komponente, kar ne pomeni, da jo zanemarja, ampak $\mathrm{v}$ nasprotju $\mathrm{z}$ etabliranim šolstvom ne zanemarja čustvene, fizične in duhovne plati otrokovega učenja, ki lahko ponudijo marsikateremu otroku, ki ima težave $\mathrm{v}$ dokazovanju svojih sposobnosti, pomembno izhodišče za nadaljnji razvoj. Pravimo sicer, da je doživljajska pedagogika pedagogika mladostništva, saj na legitimni ravni omogoča preverjanje lastnih meja. Vendar ugotavljamo, da ima posebej močan ugoden vpliv na otroke in mladostnike z vedenjskimi, čustvenimi in učnimi težavami. Metodična ustreznost se mora zrcaliti skozi individualizirana merila, pri čemer na skupino in njen socializacijski pomen ni pozabljeno.

Doživljajskopedagoški mediji so usmerjeni v naravo in v soustvarjanje projektov $\mathrm{z}$ vsemi člani skupine od vsega začetka naprej. To posledično izzove soodgovornost za izpeljavo projekta in mlade postavi $\mathrm{v}$ drugačno vlogo, kot jim jo ponuja potrošništvo, kjer so v mnogočem najboljša ciljna skupina.

Pedagoški eros in etos sta pravšnji kategoriji pri definiranju osebe doživljajskega pedagoga, kjer je potrebno ozavestiti svoje delovanje in $\mathrm{v}$ pro- 
jekte pritegniti strokovnjake različnih področij, od mornarjev, alpinistov do gozdarjev ipd.

Pedagoški cilji so postavljeni na osebna področja mladih, na socialno, motorično in kognitivno področje.

Problematika transfera $\mathrm{v}$ domače okolje ima namen osvetliti ozaveščanje razpoloženja med počitnicami in prostim časom, neadekvatnost medijev, na kratkotrajne ponudbe, pomanjkljivo evalvacijo. Temu nasproti je potrebno postaviti jasne cilje, dolžino doživljajskopedagoškega procesa, dolgoročno in homogeno skupinsko strukturo, ustrezne medije in refleksivno obdelavo. Prav tako je potrebno ozavestiti meje in nevarnosti ter tako poskrbeti za varnost.

Doživljajska pedagogika je področje pedagoške znanosti oz. pedagoška disciplina, ki je postala $\mathrm{v}$ zadnjih desetletjih tudi znanstveno utemelje$\mathrm{na}^{\mathrm{I}}$ (Krajnčan, 2007). Je znanstvena sinteza praks, ki poudarja celostno pedagogiko, osebno - odnosno ${ }^{2}$ noto ter neposredno izkušnjo kot pomembne elemente pedagoškega delovanja, ki se med seboj pomembno povezujejo (Krajnčan, 2006). Doživljajska pedagogika je način vzgajanja otrok in mladostnikov oz. vzgoja za življenje (Krajnčan, 2007; AFET, 1992 v Krajnčan, 2007). Doživljajska pedagogika se pomembno vključuje v sistem socialnopedagoške pomoči, v vzgojno-izobraževalne namene, prevencije, terapije ter sega tudi na področje prostočasne pedagogike. Uporabna je kot metoda za doseganje različnih pedagoških ciljev (Krajnčan, 2007).

Doživljajsko pedagogiko lahko razumemo kot metodo usmerjeno $\mathrm{k}$ aktivnosti, delovanju, pri kateri preko skupine in doživetij v naravi ali pedagoško kontroliranih osamljenih prostorih v naravi pridobivamo življenjsko pomembne izkušnje in kompetence, ki služijo pedagoškim smotrom ter osebnostni rasti otrok in mladostnikov (prirejeno in dopolnjeno po Heckmair in Michl, v Krajnčan, 2007). Doživljajska pedagogika je torej metoda, ki želi oblikovati vzgojni proces skozi zgledne učne procese, $\mathrm{v}$ katerih izzovemo (fizično, psihično in socialno) mlade ljudi, da bi osebno-

1 Znanstvena utemeljenost doživljajske pedagogike omogoča ustrezno edukacijo doživljajskega pedagoga, torej njegovo vzgojno in izobraževalno delo, po drugi strani pa doživljajskopedagoška praksa bogati doživljajskopedagoško znanost (Krajnčan, 2007).

2 Doživljajska pedagogika zelo poudarja tudi odnosni vidik, odnosno energijo med pedagogom in udeleženci doživljajskega projekta. V luči tega je potrebno v doživljajskih projektih upoštevati tudi pedagoški eros, ki predstavlja duhovno ljubezen do otrok in mladostnikov ter njihovega vzgajanja (Krajnčan, 2006). 
stno rastli, ter prispevamo k njihovi odgovornosti za njihov življenjski svet (Krajnčan, 2007).

Doživljajska pedagogika je metoda, ki temelji na izkustvenem učenju, spoznavanju sebe in razvijanju skupinske dinamike. Predstavlja lahko eno izmed možnosti pomoči otrokom oz. mladostnikom pri lažjem vključevanju v družbo, v manjše ali večje socialne enote in pri razvijanju lastnih potencialov. Običajno se izvaja $v$ tesnem stiku $\mathrm{z}$ naravo, ključnega pomena pa je tudi gibanje, ki ima za zdrav razvoj mladostnika velik pomen (Farkaš, 2013). Doživljajska pedagogika si prizadeva zagotoviti možnosti in priložnosti za zdrav razvoj posameznika, ohraniti želi pristen stik z naravo ter spodbujati njeno ohranjanje ter stremi k družbi, ki bi imela več občutka za sočloveka, ne glede na socialno pripadnost, barvo kože, svetovni nazor, telesno višino, številko noge, versko prepričanje ali spolno usmerjenost (Krajnčan, 2007).

Freire (1970) je predlagal, da izobraževalna praksa združuje tako akcijo kot refleksijo kot del izobraževalnega procesa. Ali kot radi rečemo, najboljši nasvet je izkušnja.

\section{Načela doživljajske pedagogike}

$\mathrm{V}$ ta namen je potrebno osvetliti načela, ki dajejo orientacijo in strukturo, preko katere lahko rečemo, da se ne ukvarjamo s fragmenti ali metodičnimi paberki doživljajske pedagogike, ki na koncu koncev to niso, ampak dejansko z metodo, ki ima smiselni okvir in celoto.

Celostnost kot nasprotje prevladujočim pogojem in strukturam učenja in življenja je najpomembnejše načelo doživljajske pedagogike. Prikazati želi alternativo enostranskosti posredovanja znanja, ki je usmerjeno v racionalnost in intelekt, in razdrobljenosti življenja na posamezna področja. Pogosto predstavljeni kot merilo vsesplošne uspešnosti in z njo tekmovalnosti. Tako se lep delež mladih znajde v spirali nasilja razdeljevanja, na tiste, ki so in tiste, ki so odvečni.

Celostnost v doživljajski pedagogiki obsega več področij. Na individualnem področju se trudi za skupno udeležbo telesa, duše in duha pri vsakokratnem dogajanju. Poleg tega gre za odpravo ločevanja med teorijo in prakso, pri čemer naj se teoretično znanje ne presoja enostransko (Ziegenspeck, v Krajnčan, 2006, str. 21).

V doživljajski pedagogiki so čustveni, umetniški, spretnostni, socialni in kognitivni učni elementi drug drugemu enakovredni, pri čemer ima te- 
lesno področje pri učenju pomembno vlogo. Čim bolj se namreč »telesno« izrinja iz učnih in vzgojnih procesov, tem bolj gre ta učni in vzgojni proces mimo celostno zasnovanih človeških potencialov in sposobnosti (Priest in Gass, 1997).

Naravnanost k delovanju; kultura današnjega časa posebej v velikih mestih in gosto naseljenih območjih močno omejuje možnosti gibanja $\mathrm{v}$ naravnem svetu (Ziegenspeck, 1992). Na mesto lastnih, neposrednih izkušenj so nujno stopile izkušnje »iz druge roke«: potrošništvo in preplavljenost $\mathrm{z}$ dražljaji namesto lastnih aktivnosti. Čas tako preganjamo s pasivnim ukvarjanjem (mediji). Doživetja iz druge roke, kot jih posreduje televizija, npr. pasivno gledanje športa, ne morejo nadomestiti samopridobljenih, samoosvojenih in intenzivno doživetih izkušenj in zapuščajo »nenasičeno dramatično potrebo«. Doživljajska pedagogika se zato usmerja $\mathrm{k}$ nujnosti samoaktivnosti, ustvarja si okvirne pogoje, ki preprečujejo pasivno udeležbo. Udeležencem mora postati jasno, da bodo lahko spremenili svoje življenjske pogoje ali se kaj naučili le z lastno aktivnostjo, da si bodo na preprostem, nazornem, jasno začrtanem polju delovanja, »tukaj in zdaj«, razjasnili povezavo med naprezanjem in rezultatom. Telesno moč je mogoče smiselno uporabiti za vsakodnevna življenjska opravila.

Naravnanost $k$ delovanju omogoča zbiranje uspehov tudi tistim mladostnikom, ki zgolj zaradi manjših intelektualnih zmožnosti ali težav pri komunikaciji le redko dobijo priznanje.

Naravnanost k skupini; doživljajska pedagogika je po načinu svojih postopkov neposredno vezana na obliko skupinskega dela. Skupinske procese vzpodbujajo okvirni pogoji projekta oz. dejavnosti. Doživljajska skupina se pogosto opira sama nase in ima komaj kaj stikov z vsakdanjim okoljem. Tako je aranžiran nekakšen »vsakdan«, v katerem so odsotni najrazličnejši odkloni sicer znanega življenjskega okolja. Zaradi zaprtega socialnega prostora se pokaže, da je v konfliktnih situacijah možnost umika ali izognitve dejanskemu toku skupinske dinamike skorajda nična. Aktivnosti so oblikovane tako, da so mladostniki brezpogojno odvisni drug od drugega. Nujno je sodelovanje, ker se drugače ekipa ne premika v pravo smer; nujna je komunikacija, saj je treba razdeljevati skupinske naloge in se pogovarjati o dnevnih načrtih; nujna je odgovornost, saj je lahko ogrožena varnost vseh, če se izgubi ali poškoduje samo kak posamezen del opreme; in nujno je zaupanje, saj ima tisti, ki sredi brzice ali na steni drži varovalno vrv, včasih v rokah življenja drugih (Ziegenspeck, 1992; Krajnčan, 2006). 
Soodločanje in sooblikovanje; s pojmom "soodločanje« želimo usmeriti pozornost tudi na modalitete odnosov med mladimi in odraslimi (vzgojitelji, učitelji).

Pozitivno je, če mladim še v fazi priprav posredujemo občutek, da gre za »njihovo stvar«, in jih motiviramo k aktivnejšemu sodelovanju, k ustvarjanju pozitivnega vzdušja.

$\mathrm{V}$ normiranem in urejenem okolju, ki ga zaznamujejo nepregledne poti odločitev, na katere ni mogoče vplivati, si mladi naberejo komaj kakšno izkušnjo, da je prek nje njihovo sodelovanje kakorkoli mogoče vrednotiti (Ziegenspeck, 1992; Krajnčan, 2006).

Voditelji doživljajske pedagogike vedo, da služi pravilno načrtovanje, še preden stopijo s svojo skupino $\mathrm{v}$ zunanje okolje, kot glavni element varnega in uspešnega vodenja doživljajskopedagoškega projekta. Enako velja za načrtovanje okolju prijaznega izleta. Razumljivo je, da mnoge dimenzije, ki se skozi projekt pokažejo kot vprašljive, izhajajo iz pomanjkljivo pripravljenih priprav, kjer je pomembna dimenzija sooblikovanje, saj občutek, da gre za ^njihovo stvar, pomeni občutek odgovornosti. To pomeni, da so vključeni v soodločanje, saj le tako lahko pričakujemo zaželene rezultate.

Nove možnosti odnosov; doživljajska skupina nudi s svojim aranžmajem možnost za spremembo nastalih razmerij in vzorcev vlog ter za vzpostavitev novih razmerij tako med mladimi kot tudi med njimi in pedagogi. Zunanji pogoji doživljajskopedagoškega procesa pa vsem udeležencem postavljajo vedno nove zahteve v zvezi z njihovo pripravljenostjo in sposobnostmi. Nujno je opustiti prejšnje odnosne vzorce, npr. pasivnost ali umik, s čimer je mogoče zadovoljiti potrebe (Ziegenspeck, 1992; Krajnčan, 2006).

Nove in nepričakovane naloge ter situacije lahko odnose spremenijo dosti bolj, kot je to mogoče v urejeni instituciji.

Naravnanost na potrebe mladih; med puberteto in adolescenco je mladostnik v fazi radikalnih fizičnih in psihičnih sprememb. Biološki vidik vsebuje nagle in občutne telesne spremembe, ki jih povzroča povečano izločanje hormonov. Hitra rast prinaša večjo potrebo po gibanju in aktivnostih. Preizkusi poguma in razna ravsanja se prirejajo za testiranje moči in spretnosti. Doživljajskopedagoško skupinsko delo daje zakonite možnosti za zadovoljitev teh potreb. Ko se približujejo svojim mejam, lahko mladi spoznajo svoje telo in se dokopljejo do boljšega presojanja samega sebe (Ziegenspeck, 1992; Krajnčan, 2006).

V tej življenjski fazi je za mladostnika osrednjega pomena vprašanje o njegovi identiteti. Sprašuje se o svoji vrednosti, o svojih slabostih in krepos- 
tih. V tem obdobju se zgradijo in izoblikujejo lastni življenjski cilji in vrednostni sistemi (Ziegenspeck, 1992; Fischer, 1999).

Sociološko gledano predstavlja mladostništvo prehodni čas med otroštvom in odraslostjo, ki je povezan $\mathrm{z}$ ekstremno negotovostjo statusa in vloge. Te negotovosti skuša mladostnik premagati s samostojnimi dosežki. Raznovrstne aktivnosti, veselje do avantur, radovednost, eksperimenti na telesnem in socialnih področjih so nujne potrebe te življenjske faze, izraz iskanja samega sebe in izraz iskanja osebne identitete. Pristop, usmerjen $\mathrm{v}$ doživljaje in dejavnosti, zelo ustreza potrebam mladostnikov. Pregleden in strukturiran okvir nudi mnogotere možnosti za izkušnjo samega sebe in izgradnjo socialnega načina vedênja ter ureditev vrednostnega sistema (Ziegenspeck, 1992; Krajnčan, 2006).

Naravnanost k naravi; marsikje je svet mladostnikov sestavljen le še iz betona in asfalta. Mnogih naravnih procesov ne doživljajo več neposredno, temveč kvečjemu prek medijev, zato se komaj še lahko izoblikuje zdrav odnos do narave. Doživljajska pedagogika se orientira na zapuščanje stanovanjskih področij in s preživljanjem $\mathrm{v}$ naravi posreduje izkušnjo kontrasta. "Neposredne« čutne izkušnje omogočata skupina in narava.

Narava s svojo avtoriteto prispeva k vzgojni usmerjenosti projekta.

Ven iz vsakdana; doživljajska pedagogika nudi v nasprotju s potrošniško enoličnim vsakdanom mnogo kontrastov, ki spodbujajo razmišljanje in posredujejo izkušnje: ven iz poplave dražljajev v življenje brez medijev, prometa in vrveža; samopreskrba namesto preobilna oskrba; prevzemanje različnih in nevsakdanjih vlog; relativno preprost način življenja namesto vsakdanje tehnike $\mathrm{v}$ prometu, kuhinji, med prostim časom ipd.; improvizacija in kreativnost namesto potrošništva; narava namesto betona; veter in vreme namesto klimatskih naprav; naravni življenjski ritem namesto prilagajanja šolskemu zvoncu, hišnemu redu ali čakanju, kdaj nastopi vzgojitelj svoj turnus ipd. (Ziegenspeck, 1992; Fischer in Mroczek, 2004). Dati krila tam, kjer so vzgojne metode podlegle. Ponuditi tisto, kar ni prisilno, čeprav je le-to dojeto kot nekaj vsakdanjega, normalnega. Treba se je boriti in skušati zajeziti avtoriteto, imenovano potrošništvo, četudi z begom v neznano okolje. Preglednost, življenje brez ustaljenih impulzov, dražljajev ponuja nove dimenzije socialnega učenja in dela na sebi (Ziegenspeck, 1992; Krajnčan, 2006).

\section{Doživljajskopedagoški cilji}

Pri metodičnem planiranju je treba odgovoriti na nekaj vprašanj. Za uspeh projekta je zelo pomembno, da pobudniki pred začetkom jasno opredelijo 
cilje, ki tedaj postanejo sredstvo, od katerega sta odvisni vsebina in podoba (Krajnčan, 2007).

Gre namreč za vprašanja, ali bodo bolj poudarili izobraževanje ročnih in motoričnih spretnosti in znanj ali pa bodo spremljevalci dajali več nasvetov, pobud, posredovali več teorije in opredelili $\mathrm{v}$ učnih vsebinah in vajah večjo strukturiranost. Če so v ospredju bolj osebnostni in socialni cilji, bodo vodili več informativnih individualnih pogovorov in več pozornosti posvetili skupinskemu procesu in vzpostavljanju odnosov. Čeprav so lahko učni cilji doživljajske pedagogike enaki tistim, ki prihajajo iz institucij, se njen učni proces občutno razlikuje. Posredovanje znanj in sposobnosti ne poteka v verbalnem seminarskem stilu, se pravi »iz glave v roke«, temveč prek dejavnega soočanja $\mathrm{z}$ nalogami in problemi »iz rok v glavo«. To velja tako za kognitivne kot za socialne učne cilje. Katalog učnih ciljev je mogoče razdeliti na več področij, pri čemer je lahko seznam v nadaljevanju le eksemplaričen in nikakor popoln (Breß, 1985). Poleg tega so posamezni cilji popolnoma odvisni od aranžmaja, skupine udeležencev, trajanja, institucije ipd. (Breß, 1985; Ziegenspeck, 1992; Fischer, 1994; Krajnčan, 2006).

\section{Cilji na osebnem področju}

Cilji na osebnem področju merijo na krepitev samozaupanja in pripravljenosti na sodelovanje, doživetja uspeha, spodbujanje izkustva in odkrivanja samega sebe, podpiranje izgradnje identitete, učenje, kako potrebe odložiti na kasnejše priložnosti, gradnjo vzdržljivosti; spodbujanje kreativnosti in zmožnosti improviziranja (socialna in spretnostna fantazija), pridobitev sposobnosti povezovanja in zaupanja drugih oseb, spodbujanje komunikacijskih spretnosti (kako posredovati veselje in bojazen, izraziti potrebe, sodelovati pri skupinskih odločitvah), prevzemanje odgovornosti zase in za druge, spoznavanje in motivacijo za drugačno preživljanje prostega časa, ponovno vzpostavljanje pozitivne naravnanosti do učenja, spodbujanje samoiniciative (razvoj občutka za kompetentno delovanje), posredovanje vtisov in lepih doživetij, ki ostanejo (Breß, 1985; Ziegenspeck, 1992; Fischer, 1994; Krajnčan, 2006).

\section{Cilji na socialnem področju}

Razvijanje občutka za skupino in občutka pripadnosti, solidarnosti, pripravljenost pomagati, sodelovanje, razvijanje pravil in njihovo upoštevanje, odkrivanje konfliktov in razvoj kompromisov, razumevanje in tolerantnost 
do šibkejših, drugačnih, sprejemanje nalog in odgovornosti za skupino, razvijanje senzibilnosti za občutke in probleme drugih.

Izkušnja intenzivne skupine se ob individualizaciji življenjskih svetov mladih pokaže za mlade kot pomembna kategorija. Socialno področje izkusijo v intenzivni, pregledni, majhni skupini, kjer je mogoče usmerjati ustrezno pedagoško delovanje. Smer je pridobivanje socialnih kompetenc, kar vodi do boljše in sprejemajoče drže pri vključevanju v okolje. Institucionalna vzgoja je na tem mestu specifična kategorija vzgoje, saj želi prenašati vrednote prek posredovanja kakršnegakoli znanja. Signifikantno je to poudarjeno $\mathrm{v}$ totalnih vzgojnih institucijah, kjer je zmeda glede kategorij posredovanja znanja in vrednot še nekoliko večja, vendar javni kritiki in strokovnim vplivom manj dostopna (Breß, 1985; Ziegenspeck, 1992; Fischer, 1994; Krajnčan, 2006).

\section{Cilji na motoričnem oz. spretnostnem področju}

Posredovanje izkušenj znanja, razvijanje grobe in fine motorike $\mathrm{z}$ raznimi športnimi aktivnostmi in ročnimi dejavnostmi, učenje tehnik različnih športov (predvsem v naravi, kot so jadranje, kajakaštvo, smučanje, plezanje), posredovanje telesnih izkušenj, razvijanje sposobnosti za smiselno preživljanje prostega časa, motivacija za športne in ročne dejavnosti, ki naj traja tudi po končanem doživljajskopedagoškem procesu - to so nekateri cilji, vendar se ob njih zavedamo, da imajo vsekakor premalo motorične vzgoje.

Področje pomeni tudi intenziven stik z lastnim telesom, saj teh izkušenj mladim prej primanjkuje, kot pa da bi jih imeli preveč. S telesnim se mladi soočajo bolj odtujeno kot kadarkoli prej, saj običajen otrok nima dovolj izkušenj lastnih naporov, fizičnih dejavnosti, aktivnosti, hkrati pa je bombardiran in prenasičen $\mathrm{z}$ formami in simboli, ki ga oddaljujejo od dejanske izkušnje sebe (Breß, 1985; Ziegenspeck, 1992; Fischer, 1994; Kiphard, 2001; Krajnčan, 2006).

\section{Cilji na kognitivnem področju}

Pred ali med projektom se vedno posredujejo tudi vsebine nekih znanj, ki nastanejo iz vprašanja ali ob pomoči situacije. Prav neposredna zveza vsebin s praktično uporabo se je pokazala kot najugodnejši učno-psihološki faktor. Navedimo le nekaj primerov znanja, ki jih je mogoče pridobiti: gospodinjsko znanje (nakup, računanje in priprava za oskrbovanje), ročno znanje in spretnosti, vremenoslovje, prometno oz. navtično znanje, orien- 
tiranje z zemljevidom in kompasom, biološke, geografske, geološke vsebine ipd. (Breß, 1985; Ziegenspeck, 1992; Fischer, 1994; Krajnčan, 2006).

\section{Tveganje na doživljajskopedagoških dejavnostih}

$S$ poznavanjem razlike med nevarnostjo in hazardi ter z zmožnostjo, da jih prepoznamo v naravnem okolju, lahko zmanjšamo možnost, da je skupina izpostavljena nezaželenim tveganjem. Kot primer ilustracije si zamislite planinarjenje, ki vključuje ledenik na potovanju na vrh. Da bi preprečili kakršnekoli nezaželene dogodke, moramo ustrezno analizirati možne nevarnosti. Uporabimo naslednji postopek desetih korakov analize nevarnosti kot način, s katerim lahko zmanjšamo verjetnost, da se bo nesreča zgodila, in če se že zgodi, da zmanjšamo njene posledice na sprejemljivo in obnovljivo raven (Priest in Baillie, 1987).

Priest in Gass (1997, str. 90) sta v ta namen izpostavila 1o korakov, ki jih je treba upoštevati v doživljajskopedagoških projektih.

1. Planirajmo vnaprej. Priznajmo si, da se nesreča lahko zgodi tudi nam. Če si mislimo, da se to ne more zgoditi nam, se norčujemo iz samega sebe. Verjetnost je, da se bo enkrat v naši karieri vodje doživljajskopedagoških projektov nesreča zgodila kljub našemu največjemu trudu. Vprašanje ni, ali se bo to zgodilo, temveč, $k d a j$ ! Pripravljeni moramo biti, da se spoprimemo skoraj $\mathrm{z}$ vsem, kar se lahko zgodi, in vzdržujemo "ponižen položaj« kot vodja. Prednačrtovanje je bistvenega pomena. Vedeti moramo, kaj bomo storili ob vsaki morebitni nesreči, preden se zgodi.

2. Iščimo nevarne situacije in pogoje. Vzpostavimo neprekinjeno iskanje, da bi identificirali nevarnosti. Moramo ostati pozorni na nevarnosti, v katerikoli situaciji. Nujno si je predstavljati, kaj se lahko zgodi, v kateremkoli trenutku. To pogosto dosežemo s stražarsko budnostjo za vse sumljive okoliščine in z nenehno pripravljenostjo, da se vprašamo »Kaj če?«. Kadar je prisotnih več nevarnosti, vzamemo to kot opozorilo, da bi bili dodatno alarmirani (budni) in previdni. Vedno izvedemo ustrezne reakcije za ravnanje v nevarnosti.

3. Označimo si potencialne nevarnosti. Ko enkrat identificiramo nevarnosti, usmerimo pozornost uporabnikov in sodelavcev nanje. Na primer, usmerjanje uporabnikove zavesti na nevarnosti iz 
okolja lahko zmanjša verjetnost nesreče, ker prepoznavajo potenciale za nesrečo, kar pogosto zadostuje, da se vedênje spremeni.

4. Kadar je ustrezno, umaknemo elemente, ki so lahko potencialno nevarni. Če usmerjanje pozornosti na nevarnost ne deluje, umaknemo nevarnost, dokler umikanje ne povečuje tveganja, da se zgodi ta ali druga nevarnost.

5. Izogibajmo se nevarnim situacijam. Če ne moremo odstraniti nevarnosti, se ji skušajmo izogniti. To lahko pomeni spremembo poteka doživljajskopedagoškega projekta. Spremenimo dejavnost popolnoma $\mathrm{v}$ drugačno smer, uberimo nov načrt, skličimo postanek, prekličimo program in dejavnost. Za namen projekta je občasno nujno, da se soočimo $\mathrm{z}$ nevarnostmi.

6. Identificirajmo in klasificirajmo nevarne situacije. Če nevarnosti ne moremo odstraniti ali se jim izogniti, je verjetno, da se bomo morali boriti z njimi, zato jih bomo morali klasificirati kot izvor izgube ali kot tveganje (pogoji, ki vplivajo na verjetnost izgube). Ta klasifikacija bi morala omogočiti, da bi se srečali z nevarnostmi, ko so tveganja minimalna, s tem bi reducirali tveganje nesreče.

7. Ocenimo tveganje in ponovno klasificirajmo nevarnost. Če se ne moremo izogniti nevarnosti, ocenimo tveganje potencialne nesreče. Nato bi morali ponovno klasificirati nevarnosti kot nevarnosti iz okolja, ki temeljijo na okoliščinah, ali kot človeške nevarnosti, ki temeljijo na skupini. Ta ponovna klasifikacija nam omogoči, da bi prepoznali, ali potencial za preseganje teh dveh sil in tveganje za nesrečo obstaja.

8. Ocenimo potencialne izgube. Če se kombinacija človeške nevarnosti in nevarnosti iz okolja pojavi, potem ocenimo verjetnost izgube. Odgovorimo si na dve vprašanji: »Koliko preseganja je pričakovanega?«, »Koliko je mogoče, da bo ta kombinacija vodila do nesreče? « Spomnimo se, da bolj številne in močnejše nevarnosti vodijo do večje verjetnosti za nesrečo. Zato bi morali identificirati ter oceniti število in moč nevarnosti v človeški kategoriji in kategoriji okolja.

9. Zmanjšajmo izgube. Če se pojavi tveganje za nesrečo kot verjetnost, toda še vedno ne kot absolutna verjetnost, izberimo potek dejanj, za katera je izid nesreče sprejemljivejši. 
10. Opravimo ustrezne prilagoditve. Če se pojavi izguba v nesreči (npr. poškodba), naredimo ponovno načrtovanje, primerne prilagoditve (npr. urnik). Odločimo se, kaj bodo naši protiukrepi, preden se nesreča zgodi. Potem ko bo to storjeno, nadaljujemo s primerno previdnostjo, $\mathrm{z}$ iskanjem novih nevarnosti, ki lahko narasejo in se združijo z že obstoječimi.

Kljub temeljiti analizi nevarnosti in pozornosti za dejavnike, ki ovirajo presojo, se nesreče lahko zgodijo! Ob taki nesreči se lahko zaporedje protiukrepov pokaže kot uporabno, ko si prizadevamo zmanjšati vpliv nesreče. Varnostne protiukrepe lahko razdelimo v tri kategorije, ki temeljijo na pravočasnosti njihove uporabe: proaktivne ali primarne, aktivne ali sekundarne ter reaktivne ali terciarne (Priest in Gass, 1997, str. 93).

Proaktivni ali primarni varnostni postopki se nanašajo na izvajanje vseh treningov pred programom, da bi se izognili nesreči ali da bi vsaj pripravili ustrezno odzivanje na nesrečo. Preventivni ali proaktivni ukrepi vključujejo pregled opreme, natančno preučitev varnosti, treniranje sposobnosti ali osebja, dovršenost legalnega administrativnega dela, pregled potencialnih nevarnosti iz narave in človeških nevarnosti ter podroben pregled uporabnikovega zdravstvenega stanja.

Aktivni ali sekundarni postopki se nanašajo na vse dejavnosti, izvedene med programom, ponavadi kot rezultat nesreče. Odzivni ali aktivni ukrepi vključujejo prvo pomoč, iskanje in reševanje, evakuacijo, beleženje podatkov o poškodbi na kraju dogodka ter odzivne postopke.

Reaktivni ali terciarni se nanašajo na vse dejavnosti, ki se pojavijo po nesreči. Ukrepi, ki sledijo dogodku, ali reaktivni ukrepi vključujejo obveščanje sorodnikov in sponzorske organizacije, zaključno dokumentiranje nesreče, vzpostavljanje stika z legalnimi svetovalci ali predstavniki zavarovanja ter načrtovane obiske pri poškodovanem uporabniku na domu ali v bolnišnici (Ziegenspeck, 1993; Krajnčan, 2006).

\section{Različna poimenovanja in pristopi}

Obstajajo specifični pristopi in poimenovanja nekaterih podobnih dejavnosti in pristopov, tako $\mathrm{v}$ ponudbi prostočasnih aktivnosti kot pomoči specifičnim skupinam uporabnikov, od otrok in mladostnikov s posebnimi potrebami do odraslih skupin, pri delu s starostniki in kot didaktično metodično dopolnilo v osnovnih in srednjih šolah, ponekod tudi v vrtcih. 
Termin »doživljajska pedagogika« danes največkrat razumemo kot naravno ${ }^{3}$-športno usmerjene dejavnosti: na vodi, kopnem in $\mathrm{v}$ zraku. Omenjeno razumevanje je po mnenju nekaterih enostransko in ozko, saj se usmerja (samo) v zunanje pedagoške dejavnosti - »outdoor«, ter ne poudarja notranjih, zaprtih ${ }^{4}$ pedagoških dejavnosti, prostorov - »indoor « (Ziegenspeck, 2005; Fischer, 2004; Michl, 2000, v Krajnčan, 2007).

Poleg doživljajske pedagogike se v literaturi pojavljata še izraza »avanturistične« in »akcijske pedagogike«, ki sta sopomenki terminu »doživljajska pedagogika« (Krajnčan, 2007).

Termin izhaja $\mathrm{v}$ germanskem prostoru iz Hahnovega poimenovanja doživljajska terapija (Erlebnistherapie) v drugi polovici dvajsetega stoletja. $\mathrm{V}$ nadaljevanju se je preimenoval $\mathrm{v}$ doživljajsko pedagogiko (Erlebnispädagogik). Sprva je bil center na Univerzi v Lüneburgu, kjer je bil tudi istoimenski inštitut (Institut für Erlebnispädagogik) z nosilcem prof. dr. Jörgom Ziegenspeckom in prof. dr. Torstenom Fischerjem, kasneje se je prenesla na univerzo v Augsburg z nosilcem prof. dr. Wernerjem Michlom in prof. dr. Michaelom Jagenlaufom. V zadnjem času se pojavlja na mnogih univerzah v nemško govorečem prostoru (Nemčija, Avstrija, Švica).

$\mathrm{V}$ anglosaškem prostoru se metoda imenuje izkustveno učenje ali izkustvena pedagogika (experiential learning ali experiential pedagogy), pojavlja se tudi termin »Outdoor adventure education«, ki bi bil še najbliže terminu doživljajska pedagogika. Umeščena je na trgu ponudb mladim $\mathrm{v}$ počitniškem času (največkrat v obliki kampov), kakor tudi kot metoda dela tako v šolskem kot univerzitetnem učenju (Off-Campus learning).

$\mathrm{V}$ skandinavskih državah je šola $\mathrm{v}$ naravi pomemben sestavni del kulture. Usmerjeni so v učenje (pogosto skozi projektno delo) zgodovine, kulture, obrti, ekofilozofije ipd. na prostem, v praktične spretnosti v realnem okolju na prostem, učijo se nordijskih smučarskih tradicij, doživljajo življenje na prostem $v$ različnih okoljih obale, gozdov in jezer ipd. Norvežani imenujejo metodo kar »friluftsliv«, kar pomeni v prevodu življenje na prostem ali rekreacija na prostem.

Na Finskem je del izobraževalne filozofije povezan $\mathrm{z}$ naravo, učijo se $\mathrm{v}$ njej o njej, ustvarjajo empatično razmerje $\mathrm{z}$ naravo, zdravje ipd. Je del ku-

3 »Elementi doživljajske pedagogike so povezani z naravo, vzgojo in izobraževanjem v preglednih in nadzorovanih pogojih, ki jih izvajalci usmerjajo v povezavi z vzgojno-izobraževalnimi cilji.« (Krajnčan, 2007, str. 9). srednjo šolo ter ostale zavode in institucije na področju vzgoje in izobraževanja ter tudi širše (področje socialnega varstva, podjetja itd.). 
rikuluma v vrtcih, šolah in univerzah. Znanje učencev se lahko vzpostavi s konkretnimi izkušnjami, interesi, čustvi in vrednotami skozi izobraževanje na prostem. Aktivirajo se različna čutila, okrepijo se vezi med afektivnim in kognitivnim področjem, kjer eno vpliva na drugo in zagotavlja most za višje sfere učenja. Pomembne so izkušnje iz prve roke in interaktivno učenje pri oblikovanju osebnih mnenj, odnosov in vrednot. Prednosti vključujejo tudi izboljšane medosebne in intrapersonalne interakcije; višja je okoljska ozaveščenost in etika skrbnega ravnanja; povečano je fizično, duševno in socialno zdravje in sposobnost učenja in koncentracije (Jeronen, Jeronen in Raustia, 2009; Marttila, 2017).

Kot je $\mathrm{v}$ tradiciji izkustvene in doživljajske pedagogike po Matti Telemäkiju, "gre za podobne pristope na Norveškem pri konceptu »friluftsliv«, na Švedskem pri »utomhuspedagogik«, v Nemčiji imamo Kurt Hahnovo filozofijo in »Erlebnispädagogik« ter v angleško govorečem svetu »adventure education «. V Sloveniji uporabljamo prevod iz nemškega jezika, in sicer doživljajska pedagogika.

V vzhodni Evropi in Balkanu se je doživljajska pedagogika nekje bolj, drugje manj začela razvijati ob koncu prejšnjega stoletja in do danes, podobno kot pri nas. Zametki novih ureditev so ponekod metodo uporabili izključno v pridobitvene namene, sčasoma so videli uporabno vrednost tudi $\mathrm{v}$ šolskem in socialnem sistemu.

\section{Razvoj doživljajske pedagogike v Sloveniji}

Kako je pravzaprav prišlo do doživljajske pedagogike v Sloveniji? Takratna asistentka na Pedagoški fakulteti v Ljubljani, takrat mag. Alenka Kobolt, je leta 1991 na predavanje povabila dr. Erich Kiehna, in sicer v okviru FICE Slovenija. Le-ta je med drugim znotraj svojih predavanj predstavil tudi možnosti, ki jih ponuja doživljajska pedagogika. Eden od avtorjev, Krajnčan, je stopil z njim v kontakt, cenjeni, žal pokojni, dr. Kiehn mu je poslal veliko literature za to področje in $\mathrm{v}$ naslednjem letu 1992, ko je pričel $\mathrm{z}$ delom kot vzgojitelj v Vzgojnem zavodu Logatec, je izpeljal prvi projekt doživljajske pedagogike »Logatčani na kolesih».

Od takrat smo izpeljali 319 projektov. Med njimi naštevamo pomembnejše, nad katerimi imamo neke vrste avtorizacijo. $\mathrm{V}$ vseh projektih smo imeli 4.145 otrok in mladostnikov iz cele Slovenije, tudi Nemčije, Hrvaške, Madžarske in Srbije. Med njimi naštevamo tiste, ki so se pojavljali pogosteje ali so bili po svojem učinku posebej izpostavljeni: 
- Indijanski tabori (Obujmo indijanske mokasine),

- Življenje na samotnem otoku (Pločica),

- Premagajmo Slovenijo z lastnimi močmi (s kolesi vzdolž Slovenije),

- $\quad$ Ljubljanica reka sedmih imen (peš in s kanuji po vseh 7 rekah),

- Življenje v starem mlinu,

- Jadranje na braceri,

- $\quad$ Živeti - ne lebdeti (projekt za otroke, nameščene v izvendružinsko vzgojo, ki nimajo med vikendi in počitnicami možnosti odhodov domov, trajajoč skozi celo leto)

- $\quad$ in še mnogi drugi.

V letu 1994 smo ustanovili Društvo za doživljajsko pedagogiko Slovenije, ki nam je predstavljalo pravno osnovo za pridobivanje sredstev, organiziranje seminarjev, konferenc, kongresov. V tem času smo izdali 15 številk revije Doživljajska pedagogika, izpeljali 3 mednarodne kongrese, letno vsaj en izobraževalni seminar in, kot rečeno, 319 projektov, skupaj 2.233 dni.

Prav tako smo leta 2000 dobili Evropsko nagrado Outward Bound za najboljši doživljajskopedagoški projekt, kar je posebej cenjeno priznanje in potrditev, da izvajamo kvalitetno strokovno in znanstveno dejavnost.

$\mathrm{V}$ takšnih in podobnih metodah ali pristopih do otrok ali mladostnikov, ne glede na njihovo pridnost, marljivost, nadarjenost, posebne potrebe, socialni izvor ipd. pride lahko do kolizije med togo in pusto znanostjo in praktično uspešnim delom. Ziegenspeck (2000), Fischer (2004), Michl (2000) in Krajnčan (2007) soglasno ugotavljajo, da je želena znanstvena eksaktnost na tako psihofizično zahtevnih dejavnostih omajana, da vemo, da projekti prinašajo pozitivne učinke na udeležence. Relevantna so vsekakor mnenja otrok in mladostnikov, ki s svojimi obrazi in energijo sevajo zadovoljstvo, kar v etabliranih šolskih in socialnih pristopih največkrat izostane.

V Sloveniji je razpoznavna na področju vzgojnih zavodov, stanovanjskih skupin, delu $\mathrm{z}$ vedenjsko in čustveno težavnimi otroki, tudi v osnovnih šolah, vrtcih, specialno pedagoških ustanovah in socialnem delu.

Doživljajska pedagogika je neposredno povezana $z$ reformno pedagogiko, z idejami, kako prezračiti šolske okvire, načine pomoči mladim ter kako jih s precej "zavožene« poti pripeljati ponovno bližje potrebam mladih, bližje logiki dejanskega življenja in uporabnega učenja. Lahko bi rekli, da je povezana z pedagoško filozofijo, saj se ukvarja s smislom izobraže- 
vanja, $\mathrm{s}$ kvaliteto odnosa, $\mathrm{z}$ možnostmi in priložnostmi v učenju, ki ostajajo neizkoriščene kljub vedenju.

Zdi se, kot da nočemo imeti boljše šole. Kot da je Althusser šolo za vekomaj ponudil politiki, ki ima samo en interes in to je vladati. Lažje vladajo, če je kritična misel odsotna, če je negativna selekcija pri izbiri učiteljskih poklicev, če je rezultat zašolan otrok, mladostnik, mlad odrasli, ki je brez kompetenc uvida v dejansko stanje, ki je oropan širokega, zvedavega, radovednega otroštva, uporabnih znanj, kritičnosti. Svojo odličnost izkazujejo z znanji potrebnimi za nacionalna preverjanja znanj, maturo, diplomo ipd., ki pa v realnem življenju odsevajo posameznika, ki se ve učiti, naučiti, ne glede na to, ali ga to zanima, ne glede na to, ali je to uporabno. Največkrat že ob objavi rezultatov omenjena znanja izgubijo na veljavi in teži.

Če $\mathrm{v}$ to godljo vštejemo še dejstvo, da šola samo potrjuje socialno stratifikacijo, to pomeni, da obstaja za nekatere šola kot prekletstvo, nekaj, kamor zelo hitro hodijo s težavo, nemotiviranostjo, nesrečo. Kakorkoli že, ni vse črno-belo. Vsekakor pa bi si šola lahko pričarala veliko več barv, pestrosti, svobode in avtonomije, ne pa da se udinja samooklicani politični eliti, ki je brez dneva prakse ali realne prakse in nikoli ni bila del šolskega vsakdana, razen kot učenci, mnogi že toliko let nazaj, da se še komaj kaj spomnijo. Pogosto tudi nimajo izobrazbe s področja, a ga kljub temu najbolj obvladajo in so nedotakljivi. Šolstvo je subtilno telo, v katerega bi bilo potrebno vlagati veliko, veliko več, saj pomeni razvoj družbe, pomeni odnos družbe do prihodnosti, pomeni osnovo za samospoštovanje in za spoštovanje lastne domovine, na katero bi lahko bili najbolj ponosni, pa žal nismo.

Zato je potrebno zavzeti ne samo kritično misel, ampak zahtevo po spremembi, zahtevo po tem, da bodo otroci dobili takšna znanja, takšne odnose in takšne možnosti, da bo šolski prostor res učenje za življenje in prostor, kamor bodo otroci želeli vstopati. Vse parole okrog šol so videti le kot politične floskule. Za zaključek tega razmišljanja si bom izposodil rek Alexandra Dumasa ml., ki se sprašuje, kako to, da imamo toliko inteligentnih otrok in toliko neumnih odraslih.

\section{Sklep}

Vsak drobec znanja, ki ga učenec pridobi sam - vsak problem, ki ga sam reši - postane mnogo bolj njegov, kot bi bil sicer. Dejavnost uma, ki je spodbudila učenčev uspeh, koncentracija misli, potrebnih zanj in vznemirjenje, ki sledi zmagoslavju, prispevajo $\mathrm{k}$ temu, da se dejstva vtisnejo $\mathrm{v}$ spomin, kot 
se ne bi mogla nobena informacija, ki jo je slišal od učitelja ali prebral v učbeniku, je že mnoga leta nazaj razmišljal Herbert Spencer.

Doživljajska pedagogika je resnična pedagogika. Uporabnost doživljajske pedagogike je v sinergiji pedagogov in uporabnikov v življenjskih situacijah, ki jih združujejo, ki imajo pedagoški potencial in ponujajo dovolj učnih situacij, katerih izkušnje so prenosljive v obči vsakdan.

Nekonvencionalnost zbuja pomisleke, zato si konvencionalni strokovni delavci nikakor ne morejo predstavljati pomena in učno-vzgojnih učinkov nekje daleč od civiliziranega sveta, prepuščeni samim sebi. Doživljajskopedagoški projekti morajo predstavljati izziv izvajalcem in so podvrženi višji stopnji rizika kakor kabinetno-učilniški sistem vzgoje in izobraževanja. Vendar za skupine otrok in mladostnikov, ki imajo v konvencionalnem izobraževalnem sistemu težave, lahko pomeni doživljajska pedagogika pomembno izkušnjo na poti sprejemanja konvencionalnega. Doživljajska pedagogika se spogleduje s socialno deprivilegiranimi skupinami, posebej zato, ker $z$ intenzivnimi programi prinaša pomembne socialne veščine. Iz istega razloga je uporabna za vse skupine otrok in mladostnikov ter druge ciljne skupine.

V Sloveniji smo doživljajsko pedagogiko vzpostavili na raven prepoznavnosti. Posebej na področju socialnopedagoškega dela se je izkazala kot zelo koristna in dobra metoda. Tudi projekti ali pristopi, ki so vezani na bližino izvajanja, z minimalnimi sredstvi, se izkažejo kot učinkoviti. Vsekakor za tem izvajanjem vedno stojijo usposobljeni in visoko motivirani strokovni delavci.

Prav tako se kot obroben del reformne pedagogike kritično reflektira $\mathrm{v}$ odnosu do etabliranega šolstva in izobraževanja nasploh, kakor tudi do vzpostavljenega sistema socialne pomoči in pomoči otrokom in mladostnikom s težavami v svojem socialnem vključevanju.

\section{Literatura}

Breß, H. (1985). Outward Bound - Persönlichkeitsbildung durch Erlebnispädagogik. Die deutschen Kurzschulen als Alternativen zu Passivität und Resignation. Deutsche Jugend, 33(5), 222-226.

Farkaš, M. (2013). Doživljajska pedagogika v osnovni šoli (Diplomsko delo). Univerza v Ljubljani, Pedagoška fakulteta, Ljubljana.

Fischer, T. (1994). Grundbegriffe der Erlebnispädagogik. Erlebnispädagogik, 14(9). 
Fischer, T. (1999). Erlebnispädagogik. Das Erlebnis in der Schule. Frankfurt/M: Peter Lang Verlag.

Fischer, T. (2003). Informelle Pädagogik. Hamburg: Verlag Dr. Kovač.

Fischer, T., in Mroczek, P. M. (2004). Pädagogik und Therapie. Hamburg: Verlag Dr. Kovač.

Freire, P. (1970). Pedagogy of the oppressed. New York, NY: Continuum.

Jeronen, E., Jeronen, J., in Raustia, H. (2009). Environmental Education in Finland - A case study of environmental education in nature schools. International Journal of Environmental \& Science Education, 4(1), 1-23.

Krajnčan, M. (2006). Teoretske osnove doživljajskopedagoškega dela. Doživljajska pedagogika, 12(15), 13-48.

Krajnčan, M. (2007). Osnove doživljajske pedagogike. Ljubljana: Pedagoška fakulteta.

Marttila, M. (2017). Learning in the nature - Integrating outdoor adventure education into the curriculum for adolescents with learning disabilities. Jyväskylä: University of Jyväskylä, Department of Sport Sciences.

Michl, W., in Heckmair, B. (2004). Erleben und Lernen. München: Reinhardt.

Priest, S., in Baillie, R. (1987). Justifying the risk to others: The real razor's edge. Journal of Experiential Education, 16(1), 50-53.

Priest, S., in Gass, M. A. (1997). Effective leadership in adventure programming. New Hampshire: Human Kinetics.

Ziegenspeck, J. (1992). Erlebnispädagogik. Rückblick - Bestandsaufnahme Ausblick. Lüneburg: edition erlebnispädagogik.

Ziegenspeck, J. (1993). Hintergrundinformationen $\mathrm{zu}$ einem praktisch bedeutsamen und theoretisch interessanten Erziehungsfeld. Zeitschrift für Erlebnispädagogik, 13(1), 5-10.

Ziegenspeck, J. (2000). Handbuch Orientierungstuffe. Sachstandsbericht und Zwischenbilanz. Bad Heilbrunn: Klinkhart.

Ziegenspeck, J. (2005). Erlebnispädagogik - eine neue Wissenschaftsdisziplin zwischen Theorie und Praxis, Tradition und Fortschrift, Affirmation und Innovation. V M. Krajnčan in N. Cvirn (ur.), Mesto in vloga doživljajske pedagogike: Zbornik povzetkov 2. slovenskega kongresa doživljajske pedagogike (str. 13-20). Ljubljana: Društvo za doživljajsko pedagogiko Slovenije. 



\section{Imensko kazalo}

A

Adler, A. 20

Altenthan, S. 35

Anzeljc Bratina 135, 136, I38, I39, I43, I 44

Anzeljc, N. 135, I36, I38, I39, I 43, I 44, 185

Apple, M. W. 123

B

Baillie, R. 197

Bajc, K 157

Bajželj, B. IIO, III, II 2, II3, II9, I22, I 49

Baker, M. C. 160

Banks, C. A. M. 154, 162

Banks, J. A. 154, 162

Barber, B.L. 154

Barle Lakota, A. II6

Batistič Zorec, M. 54

Bauer, P. I3, I4, I7, I8, I9, 21

Baumrind, D. I8

Beare, H. 94, 97
Bečaj, J. 42, 44, 50, 55, 57, 58, 59, I32, I35

Bennett, P. L. 46

Berdajs, A. 69, 156

Berger, R. A. 172

Bernjak, E. 159

Bešter, R. 80, 82, 153

Biloslavo, R. 95

Böhm, W. 34, 35

Bouillet, D. II6

Bourdieu, P. I 49, I50, I5I

Braddock, J. H. 154

Bregant, L. 55, 57

Brendtro, L.K. 3 I, 32

Breß, H. 195, 196, 197

Brezinka, W. I5

Bronfenbrenner, U. 43

Buchmann, M. 17, I9

Bürger, U. I3I, I32, I34

Byrne, Š. 43

C

Caldwell, B. 94

Carbonaro, W. 153 
Cattel, V. I39

Collier, V. P. I59, I60, I6I

Colombo, A. D. I5O, I5I, I52

Cooper, P. 47

Cummins, J. I60, I6I

Cvajner, M. I50

$\check{C}$

Čančar, I. 74

Černič, M. I52

Čok, L. I59

Črnak Meglič, A. II 8

D

Damm, M. I5, I7, 2 I

Dekleva, D. 52, IIO, II5, I33

De Laat, W. ${ }_{103}$

Delors, J. I53

Dewe, B. 26

Dewey, J. 16

Dika, L.S. 153

Dimovski, V. IO4

Domanjko, B. 177

Downey, D. B. 153

Drucker, P. 93, IO2, $\mathrm{IO}_{4}$

Dubois, D. L. 80

Dumas, A. 203

E

Eccles, J.S. I54

Einhardt, M. I7, I8, I9, 2 I

Erčulj, J. IO2

Evans, J. 48

E

Farkaš, M. I9I

Fischer, T. 194, 195, 196, 197, 200, 202

Forness, S. 49

Freire, P. 13, 16, 34, I9I
Fritsch, G. 17

Frommann, A. I40

G

Galimberti, U. IIO, III, I I 4, I I5, I23

Gardner, H. IIs

Gass, M. A. 192, 197, 199

Gaustad, J. 80

Gay, G. 156

George, M.J. I05

Gerr, H.E. I8

Gibbons, P. I6I

Giesecke, H. 24

Giroux, H. 16

Globačnik, B. I19, I20

Goffman, E. 27

Grob, A. 20

Gronenmeyer, M. 122

Grünfeld, T. I 7

Grunwald, K. II I, II 8, II9, I20, I2 4, I36

Guiterezz, K. D. I54

Gutzwiller Helfenfinger, E. I7

$\mathrm{H}$

Haji Kella, M. I54, I55

Halmi, A. II 8

Hanuš, B. 84, I58, I59

Harden, A. 48

Heckmair, B. 190

Hendricks, H. G. II

Hlebec, V. I7I, I77

Hrovatin, N. 91, 92

Hrženjak, M. I 40

Hurrelmann, K. I3, I 4, I8, I9, 20, 2 I

Hvalič Touzery, S. I 82 
Jahn, S. 35

Jaschinski, U. 20

Jelenc Krašovec, S. I74

Jelen Madruša, M. 80

Jelovac, D. 9I, 93, IOI

Jensen, H. IIO, II I, II5

Jereb, A. 80

Jeronen, E. $20 \mathrm{I}$

Jeronen, J. 20 I

Jones, R. G. IO5

Jordan, W.J. I54

Judge, T. A. 95, 96,97

Jug Došler, A. 74, 82

Juul, J. IIO, III, II5

\section{K}

Karcher, M.J. 80

Kaufmann, J. M. 42

Kelly, A. V. I I 4

Kenneth, K. 49

Kerman, K. I Io

Kiehn, E. 20I

Kiphard, E.J. 196

Kladnik, T. I73, I77

Kleinert, H. 25

Klemenčič, E. 154

Klemenčič Rozman, M. M. IIO, IIs

Klinar, P. 83

Knaflič, L. 73, 83, 85, I53, I58, I59

Knez, M. 73, 78, 79

Kobal Tomc, B. 42, 47, 48, II 8, I2 O, I35, I36, I 43, I 44

Kobolt, A. 41, 42, 43, 48, 49, 50, 52, 53 , $54,55,59$, IIO, I23, I 4 , I3O, I3 I, I32, I36, I 40, I 42, 201

Kogoj, B. I59

Kohn, A. 16

Kolarič, Z. 90

Komac, M. 75
Koren, M. I03, IO5

Kosmač, S. 4I, 43, 48, 49, 50, 55, I30, I34

Kovač, B. 92

Krajnčan, M. II, I2, 42, 44, 48, 49, 54, IIO, III, II 2, II I I I 7, II I, I II, I22, I 23, I3O, I3I, I32, I33, I34, I35, I36, I37, I38, I 4O, I 4I, I 42, I 43, I 44, I9O, I9I, I92, 193, 194, 195, 196, 197, 199, 200, 201, 202

Krappmann, L. 26

Krek, J. 73, 76, 79, II3

Kristančič, A. I7I, I72, I73, I74, I75, I77

Kroflič, R. II 4

Kuhar, R. 156

Kump, S. 174

L

Laval, C. II 6

Leone, P. E. 4I

Lesar, I. 74, 82, 83, I55

Levin, K. I8, 22, I52

Lipičnik, B. 98

Logaj, V. IoI

Loughran, J. I 4

Lük Nećak, A. 158

Lukšič-Hacin, M. 162

M

Maas, A. 103

Maccoby, E. E. 17, 19, 20

Magajna, L. 76, 77

Magdič, J. 83

Makarovič, M. I52

Mali, J. I79, I80

Marjanovič Umek, L. I57

Marovič, M. 42, 49, I39, I 49, I5I

Mars, A. 47 
Martin, J. A. 17, 19, 20

Marttila, M. 20I

Mautke, B. 20

McNeal, R. I53

Medvešek, M. 75, 80, 82, I53

Medveš, Z. 79, I59

Metljak, U. 4I, 42, 43, 45, 46, 47, 49, $54,56,60$

Michl, W. 190, 200, 202

Miketič, A. 160

Miklavžin, P. I 44

Mikulec, V. 82

Mikuš Kos, V. A. 8I

Miller, C. 80

Miller, S. M. 80

Millikan, R. 94

Miloševič Arnold, V. I79

Mittler, P. 55

Mollenhauer, K. 33

Morgan, S. I53

Mostert, M. 49

Mroczek, P. M. 194

Müller, A. 26, 27, II I, I 44

Myschker, N. 42, 43, 46, 47, 48, 49

N

Nader, P. R. 103

Nagode, M. I79, I80

Nastran Ule, M. I55

Neuman, T. I58, I59

0

Ockhardt, S. I7

Opara, B. 43, 48, 49, IIO, I 20, I37, I 43 Otto, H.U. 26

P

Pahor, M. 177

Peček Čuk, M. I55
Pečjak, V. I69, I70, I7I, I72, I73, I80

Podgornik, N. I52

Polak, A. II 6

Pong, S. 153

Potočnik, Š. 4I, 49

Pribesh, S. I53

Priest, S. 192, 197, 199

$\mathrm{R}$

Ramovš, J. I7 I, I73, I75, I76, I77, I78, I 8I

Rapuš Pavel, J. I II, II 8, I3I, I32

Raustia, H. 20 I

Razdevšek-Pučko, C. I59

Razpotnik, Š. 4I, 48, 49, 54, III, II 8, II9, I2 O, I2 I, I 4I

Redl, F. 44, 53

Resman, M. 99, I54, I58, I62

Riedl, H. I7, 22

Robbins, P.S. 95, 96, 97, 104

Rončević, B. 90

Roter, P. 75

Rupar, B. I03, I05

Rupnik Vec, T. 49, 53, I03, I05, I09

Russell, T. I 4

Rutar, D. IO6, III, II 4, II5, II6, I23

Rutar Ilc, Z. I06

S

Saled, R. I is

Satow, L. I7

Schein, H. E. 95

Scheithauer, H. 20

Schollaert, R. IO3, $\mathrm{IO}_{4}$

Schultheiss, A. 4I

Schultz, T. W. I5I

Sciortino, G. I50

Sedmak, M. I70, I78

Seidenstücker, B. 20

Singh, K. I53 
Sinjur, A. 7I, 75, 83, I02, I05, I 40, I69 Thompson, J. W. I72

Skalar, V. 44, 45, 49, 5I, 55, 58, II3, II6, Tomori, M. 58 II 7, I23, I3O, I3I, I32, I35, I83

Skela, J. I59

Toplak, K. 156

Trade, W. I3I, I32

Skubic Ermenc, K. 74, 78, 79, 82, 83,

Trieschman Albert, E. 31, 32 I58, 159

Trnavčevič, A. Ioo, IOI

Skutnabb-Kangas, T. I6I

Smyth, G. I59, I60, I6I

Snoj, B. Ior

U

Sočan, G. 157

Sørensen, A. 153

Spajić Vrkaš, V. I3, 35

Spencer, H. 204

Straus, L. 83

Sun, Y. I53

Svetin Jakopič, S. 43, 4 4, I30, I35, I36, I 43

Svetlik, I. 94

Š

Šircelj, M. I69, I70, I7 I

Škoflek, I. 44

Škrinjarič, K. IO5

Šoln Vrbinc, P. I36, I37, I3 8, I 43

Štefanc, D. I IO, II 4, II9

Štrajn, D. IO4

Štremfel, U. II6, I54

T

Talib, M. T. I56

Tatković, N. 84

Tausch, A. M. I5, I7, 22

Tausch, R. I5, I7, 22

Uzelac, S. II 6

$\mathrm{V}$

Vah Jevšnik, M. I56

Valenčič Zuljan, M. II7

Van Dougen, J. IO3

Van Weezel, L. G. 29, 30, 32, 34

Vehovar, U. I52

Vernooji, M. A. I I I

Vezovnik, A. 82,83

Vidmar, M. Iı

Visser, J. 48

Vižintin, M. A. 66, 68, 74, 76, 78, 82

Vodopivec, V. 93, 97, 99

Vogrinc, J. 73, 76, 79

Vovk Ornik, N. Io9

Vršnik Perše, T. I20, I23

W

Waaldijk, K. 29, 30, 32, 34

Wexberg, E. I5, 20

Whittaker, J. K. 3I

Wineman, D. 44,53

Wolf, K. 26, 27, 28

Tavčar, M. IO3, 104

Taylor, M. I55

Tekavčič, M. IO2

Terzi, L. 48

Thiersch, H. 28, III, II 8, II9, I20, I22, I2 4, I36

Thomas, J. 48, 54, I59, I60, I6I

Z

Zalokar, L. 50, I35, I 40, I 43

Ziegenspeck, J. I91, 192, I93, 194, I95, 196, 197, 199, 200, 202

Zorc Maver, D. 43, IIO, II 7, I2 I, I 44 Zrim Martinjak, N. I39 



\section{Stvarno kazalo}

C

center za socialno delo 52, 89, I29, I30,

I3I, I33, I34, I35, I37, I 40, I 42, I8I

civilna družba 92, 93, I79

$\check{C}$

človekove pravice $65,67,69,8 \mathrm{I}$

človeški kapital 94, I50, 198

človeški viri 89, 106

čustvene in vedenjske težave/motnje $4 \mathrm{I}$, $42,43,48,49,50,51,52,54,55,57,58$, $59, \mathrm{I} 34, \mathrm{I} 35, \mathrm{I} 43, \mathrm{I} 44$

čustvene težave II, 4I, 42, 43, 45, 46, 47, 51, 53, 55, 57, 58, 94, 96, I09, I IO, II 2, I2O, I22, I32, I89

\section{D}

demokratična družba 67, 69, II2, II3, I5 4

diagnostika 29, 46, 49, 55, 57, III, II 7, II 8, II9, I 2O, I23, I37, I 43

diferenciacija $74,77,78,79$, I I9, I80 dijaški dom 89,92

diskriminacija $13,66,154,155,156,162$,

I 72

disocialni vedenjski sindrom 132

dodatna strokovna pomoč 83, IO9, I2I, I23

dodatni pouk 73, 74, 76, 77,8I

dom za ostarele 92, I69, I79, I80, I8I, I 84

dopolnilni pouk 70, 74, 75, 76, 77

doživljajska pedagogika I89, I90, I9I,

192, 193, 194, 195, 200, 201, 202, 204

doživljajskopedagoški proces I90, I93

družba 5I, 69, IOI, I 4I, I53, I75, I79

družbeno izključevanje 155

dvojezičnost I59, I60, I6I

E

ekonomski kapital I 49, I50, I5 I

enake možnosti 65, 66, 67, I 42

enojezičnost I60, I6I

etnocentrizem 155 
G

gerontofobija 172

gerontologija I7I

globalizacija 92, 100, 102

$\mathrm{H}$

humanizacija II 3, I23, I 44

I

identifikacija 158

identiteta 26, 28, 68, 70, 96, 97, I16, I54, I55, I58, I62, I94, I95

individualizacija 74, 77, 78, 79, I19, 196

individualizirani vzgojni načrt 138

individualna skupinska pomoč ro9

individualna strokovna pomoč 13,45 ,

$54,73,76$, I09, I 44

individualni program 77,78

inkluzija 83 , II 8

integracija 28, 46, 83, 96, II9, I39, I53, 178

intervencije 50, 56, II 8, I30, I 43, I 83

izključevanje I2I, I56

izobraževanje $16,23,26,65,66,67,68$, 69, 71, 73, 75, 82, 83, 84, 90, 91, 93,

94, IO S, IIO, III, II2, II I II 4, II 6,

I2O, I 29, I3 8, I 4O, I 4I, I 42, I 43, I 53 ,

I57, I60, I62, I70, I73, I74, I75, I76,

I8I, I95, 200, 201, 203, 204

izstopajoče vedenje 50, 52, 54

J

jutranje varstvo I09

K

komunikacija I8, 26, 83, I05, I62, I73,

I75, I77, I78, 192

Konvencija o otrokovih pravicah 65

krizni center 92 kultura organizacije 94, 95, 96, 97, 99, IOI, 106

kulturni kapital 78, I 49, I50, I5I, I54, I 62

M

marginalizacija I24, I56, I62, I75

marketing IOO, IOI

medgeneracijsko sodelovanje 177

medkulturnost 65, 66, 69, 78, 82, 84, I5 4,162

menedžment $16,89,91,93,105$

migracije I5I, I69, I70

migranti $67,68,71,158$

mladinski dom II, 58, 92, I35, I36, I37, I 4 I

mladostnik I2, I3, 24, 28, 33, 42, 43, 44, $48,50,52,54,55,56,57,59$, IO9, IIO, III, II 2, II 3, II 4, II 8, II I, I2O, I2I, I29, I3O, I3I, I32, I33, I34, I35, I36, I37, I38, I39, I 40, I 4I, I 42, I 43, I 44, I90, I9I, I92, I93, I94, I99, 20I, 202 , 203,204

moteče vedenje 50, 53

motivacija 30, 8I, I58, 196

motnje II, 4I, 43, 44, 45, 46, 47, 48, $50,52,53,55,56,57,58,59,60,81,109$, IIO, II 2, II9, I2O, I 22, I3O, I32, I35, I36, I37, I 4O, I 4I, I 42, I 43, I 44, I 55 , 178

N

nacionalna identiteta 67 nameščanje v vzgojni zavod 52, 53, 56, I3O, I3I, I32, I33, I34, I35, I36, I37, I38, I39, I 4O, I 42, I 44

neprofitne organizacije 89,90,91, 92, 93, 94, 98, 99, I00, I01, 106, I79 nevladne organizacije 8 I, 89 
novopriseljeni učenec 80

0

ocenjevanje znanja 29, 65, 72, 76, 77, 82, II 8, I6I

odnos I2, I6, 21, 23, 24, 25, 26, 28, 30, $32,35,36,37,56,66,67,84,91,100$, IOI, IIO, III, II2, II , II , II9, I23, I39, I 49, I50, I52, I53, I56, I57, I62, I70, I74, I75, I76, I77, I84, I93, I94, I95, 201, 203

opismenjevanje 73

opolnomočenje I22, I23, I24 organizacijska struktura 89,97,98,99, 106

osnovna šola 51, 52, 54, 65, 66, 67, 69, $70,71,72,73,75,76,78,79,81,82$, $83,84,89,92$, IO9, IIO, III II 2, II3, II 4, II , II 6, II7, I 2O, I 2I, I22, I 23 , I24, I29, I57, I6I, 200, 202

osnovnošolsko izobraževanje 5I, 66 otrok II, I2, I3 , I 4, I5, I7, I8, I9, 20, 2I, $23,24,25,26,27,28,30,31,33,34$, $37,4 \mathrm{I}, 42,43,44,45,46,47,48,50$, $51,52,54,55,56,57,58,59,65,66,67$, 68, 69, 70, 7I, 73, 77, 80, 8I, 83, 85, 9I, IO9, IIO, III, II 2, II , II 4, II 7, II 8, II9, I2O, I2I, I 23, I 29, I3O, I3I, I32, I33, I34, I35, I36, I37, I3 8, I39, I 40, I 4 I, I 42, I 43, I 44, I 50, I 5 I, I 52 , I 53 , I54, I56, I57, I58, I59, I60, I6I, I62, 173, 189, 190, 191, 196, 199, 201, 202, 203, 204

otrok/mladostnik 4I, 50, 57, II2, I34, I36

otrokove pravice $8 \mathrm{I}, \mathrm{I} 43$

otrok s posebnimi potrebami 42,45 ,

47, 55, IO9, IIO, II 7, II 8, II9, I20, I 2I, I29, I 43
P

participacija 30, II9, I22, I58, I70, I85

pedagoški eros II 4, I23, I89, I9O pedagoški etos II3, II 4, I22, I23, I2 4, I 89

pedagoški odnos I19, I22 pluralizem 69, I54 podaljšano bivanje I09 poljezičnost 159 predsodki 4I, 68, 85, I54, I55, I56, I57 prevencija II9, I22, I9O preventiva 122 preverjanje znanja I 4, 65, 72, 73, 76, 77 , $82,83,189$

prevzgojni dom 92 priseljenci $68,69,7 \mathrm{I}, 72,74,75,78,80$, 8I, 82, 84, I5O, I52, I53, I55, I58, I62, I 63

priseljenski učenec $65,67,68,69,70$, $7 \mathrm{I}, 72,73,75,76,77,78,79,80,8 \mathrm{I}$, $82,83,84,85, \mathrm{I} 40, \mathrm{I} 49, \mathrm{I} 50, \mathrm{I} 53, \mathrm{I} 56$, I57, I60, I62, I63 profesionalni odnos IIO, II I profitne organizacije 9I, 93, IOI, I79, I8I $\mathrm{R}$

regionalizacija II9 (re)integracija 139 romska populacija I39, I 40

S samopodoba $18,44,162,173,176$ segregacija 79, I62 skupine za samopomoč 92 skupinska dinamika 53, I91, I92 skupinska pomoč 76, I09 Slovenija II, 42, 65, 66, 67, 68, 69, 70, 7I, 72, 73, 75, 78, 80, 8I, 83, 90, II6, 
II 7, I 29, I35, I39, I 4I, I 43, I52, I5 4, I62, I70, I78, I79, I80, I82, 201, 202, 204

sobivanje 173

socializacija 160

socializacijski procesi 68,157

socialna izključenost 156, I62

socialna pedagogika II, I6, 92, IIO, II 4, II5, II G, II 7, II9, I2O, I22, I23, I 4I, I 42, I 49, I 7 I, I 83, I 84, I 86

socialni kapital 24, 25, 28, 43, 44, 49, $56,59,92$, III II I , II I , I I 4, II I I I 7, I2O, I I, I32, I39, I 4I, I 42, I 43, I 49, I5O, I5I, I52, I5 4, I58, I63, I74, I75, $\mathrm{I} 78, \mathrm{I} 80, \mathrm{I} 83, \mathrm{I} 84, \mathrm{I} 85, \mathrm{I} 92, \mathrm{I} 94,200$ socialni pedagog $16,24,25,26,27,28$, $42,89,92,94,97,98$, IO9, IIO, III, II 2, II3, II 4, II 5, II6, II 7, II 8, II 9, I2O, I II, I22, I23, I2 4, I 4I, I 43, I63, I 84, I 85, I 86

socialnopedagoška diagnostika II7, I I 8, II9 socialnopedagoška doktrina 42, I I I, I 40

socialnopedagoška pomoč 190 socialnopedagoški diskurz IIO, I2 4 socialnopedagoško delovanje 89 , Iо०, IOI, IO2, IO6, IO7, IIO, II 6, I20, I 84 sooblikovanje 193

soodločanje 98, I93 spoštovanje drugačnosti $67,68,69,70$, I2I, I54

srednja šola 89, 92, I57

stanovanjska skupina II I I , 58, 89, I 8I, I84, 202 staranje I69, I70, I7I, I72, I73, I74, I75, I77, I78, I79, I8I, I 85

starostnik I7I, I85, 199 stereotipi 85, I55, I56, I78, I86

strokovna pomoč $8 \mathrm{I}, \mathrm{I} 44$

Š

šola s prilagojenim programom 92 šolska praksa 78, 81, 82, I60

T

težave II, I2, I9, 29, 36, 4I, 43, 44, 45, $46,47,48,49,50,51,52,53,54,55$, $56,57,58,59,60,76,77,81,82,89,91$, IO2, IO9, II7, II9, I2O, I 2I, I22, I3O, I3I, I32, I33, I34, I35, I36, I39, I 40, I 4I, I 43, I 44, I56, I59, I60, I62, I77, I78, I79, I86, I89, I92, 203, 204 težave v socialni integraciji 50, 55 trajnostni razvoj 67, II 2 trigeneracijske družine I73, I86<smiles>C1=CCC=C1</smiles>

upravljanje s človeškimi viri 93,94<smiles>C1C2CC12</smiles>

varstveno delovni center 92 večkulturnost $66,69,84,154$ vedenje II, I2, I3, I5, I6, I8, I9, 20, 35, 4I, $43,44,45,46,47,48,49,50,52,53$, $54,57,58,59,60,67,81,95,97,100$, III, I 22, I3I, I33, I34, I35, I36, I37, I 40, I 42, I 43, I 44, I60, I70, I 78, I 85 vedenjske težave II , 20, 24, 25, 4I, 42, $43,44,45,46,47,48,50,51,52,53$, $55,57,58,59$, IO9, IIO, II 2, I 20, I 22, I30, I33, I34, I35, I36, I 42, I 43, I 89 vključevanje $\mathrm{I} 6,36,65,67,68,70,73$, 74, 78, 80, 8I, 82, 83, 84, 85, I IO, II 2 , I 40, I 42, I 49, I50, I 52, I53, I 56, I 57 , I59, I6I, I62, I63, I70, I84, I85, I9I, 196, 204 
vodenje $16,36,53,89,91,92,93,97,98$, I05, IO 6, II2, II 8, I93

vrstniška pomoč $80,8 \mathrm{I}$

vrtec I2, 68, 89, 92, I57, I58, 199, 200, 2OI, 202

vseživljenjsko učenje 174,176

vzgoja II, I2, I3, I 4, I5, I6, I7, I 8, I9, 20, $21,23,24,26,27,28,32,34,35,36,37$, 4I, 42, 50, 5I, 53, 54, 56, 59, 65, 66, 67, $68,69,70,7$ I , 73, 80, 82, 85, 92, IIO, III, I I 2, II3, II 4, II 7, I 20, I29, I30, I32, I34, I36, I38, I 40, I 4I, I 42, I 43, I 44, I5O, I52, I54, I57, I62, I7 I, I73, 189, 190, 196, 200, 202, 204 vzgojna neuspešnost 130 vzgojna pomoč 34, II 8 vzgojni stili I2, I6, I7, I8, I9, 20, 21, 22, $23,36,133$

vzgojni zavod I 2, 27, 42, 43, 49, 50, 51, $52,53,54,55,56,57,58,60,89,92$, I29, I3O, I3I, I32, I33, I34, I35, I36, I37, I38, I39, I 4O, I 4I, I 42, I 44, 201 , 202

vzgojno delovanje 123

vzgojno-izobraževalni proces 74 vzgojno-izobraževalni sistem $67,73,8 \mathrm{I}$, $82,84,85$, II3, II 6, II 8, I 23, I 49, I57 vzgojno-izobraževalni zavod I35, I36, I37

\section{Z}

zakonodaja 42, 45, 49, 50, 65, 66, 67, 68, 70, 71, 72, 73, 76, 81, 82, 90, 91, I00, I 29, I38, I 42, I58, I80, I8I

zapor 89,92 zavodska populacija 51, 52, 53, 55, 56, 57, $58,59,60,138,139$ zavod za usposabljanje 92 življenjska obdobja I74, I76, I77, I83, I 84 




\section{IZ RECENZI]}

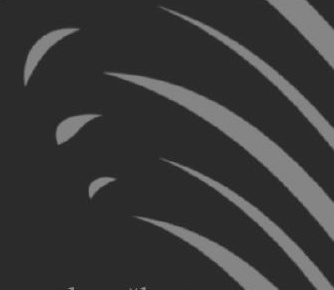

Monografija prinaša informativne, edukativne in suportivne socialnopedagoške vsebine $\mathrm{V}$ polju razumevanja ranljivih družbenih skupin/posameznikov. Dokumentira različne teoretične diskurze ter kvalitetne in reflektirane izkušnje avtorjev/avtoric. Delo sestavljajo heterogeni prispevki, v katerih najdemo analizo vzgojnih diskurzov, metodike dela z vedenjsko težavnimi otroki/mladostniki, podporne oblike pomoči priseljenskim učencem, pomembnost upravljanja s človeškimi viri, socialnopedagoške potenciale pri zagotavljanju inkluzivnega okolja, temeljne elemente doživljajske pedagogike in njeno aplikativno vrednost na področju socialnopedagoškega delovanja. Prispevki se medsebojno dopolnjujejo, hkrati pa usklajujejo vrzeli med teorijo in prakso. Monografija na podlagi kvalitetnega raziskovanja ter domišljenosti diskurzov, ki pomembno prispevajo $\mathrm{k}$ razvoju socialnopedagoške doktrine, prinaša dodano vrednost $\mathrm{v}$ celotnem sistemu formalne/neformalne pomoči različnim depriviligiranim skupinam/posameznikom.

PROF. DR. OLIVERA GAJIĆ

Monografija predstavlja vsebinsko bogato in poučno celoto v socialnopedagoškem vzgojno-izobraževalnem polju. Teksti zajemajo različna socialnopedagoška področja, povezana $\mathrm{z}$ ranljivimi družbenimi skupinami. Nekateri obravnavajo teoretske in konceptualne vidike, drugi se bolj osredotočajo na raziskovanje socialnopedagoških praks. Avtorji/avtorice prispevkov - $\mathrm{z}$ integracijo teorije in prakse preko ustrezno izbranih raziskovalnih metod $-\mathrm{z}$ različnih zornih kotov osvetlijo socialnopedagoško doktrino, na podlagi česar monografija predstavlja pomemben doprinos na socialnopedagoškem področju, ki je s populacijo s posebnimi potrebami najbolj neposredno povezano.

PROF. DR. TORSTEN FISCHER

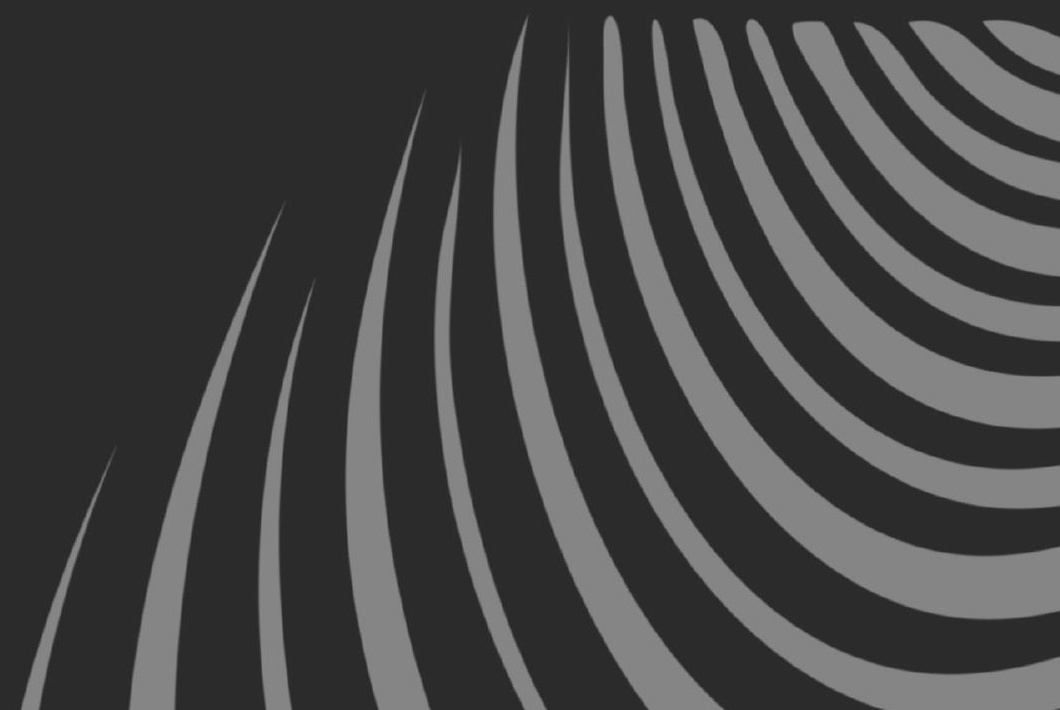

